Pacific Northwest

National Laboratory

Operated by Battelle for the

U.S. Department of Energy

\title{
Uranium in the Near-Shore Aquatic Food Chain: Studies on Periphyton and Asian Clams
}

\author{
AL Bunn \\ TB Miley \\ CA Brandt \\ PW Eslinger \\ BA Napier
}

December 2007

Prepared for the U.S. Department of Energy

under Contract DE-AC05-76RL01830 


\title{
DISCLAIMER
}

This report was prepared as an account of work sponsored by an agency of the United States Government. Neither the United States Government nor any agency thereof, nor Battelle Memorial Institute, nor any of their employees, makes any warranty, express or implied, or assumes any legal liability or responsibility for the accuracy, completeness, or usefulness of any information, apparatus, product, or process disclosed, or represents that its use would not infringe privately owned rights. Reference herein to any specific commercial product, process, or service by trade name, trademark, manufacturer, or otherwise does not necessarily constitute or imply its endorsement, recommendation, or favoring by the United States Government or any agency thereof, or Battelle Memorial Institute. The views and opinions of authors expressed herein do not necessarily state or reflect those of the United States Government or any agency thereof.

\author{
PACIFIC NORTHWEST NATIONAL LABORATORY \\ operated by \\ BATTELLE \\ for the \\ UNITED STATES DEPARTMENT OF ENERGY \\ under Contract DE-AC05-76RL01830 \\ Printed in the United States of America \\ Available to DOE and DOE contractors from the \\ Office of Scientific and Technical Information, \\ P.O. Box 62, Oak Ridge, TN 37831-0062; \\ ph: (865) 576-8401 \\ fax: (865) 576-5728 \\ email: reports@adonis.osti.gov \\ Available to the public from the National Technical Information Service, \\ U.S. Department of Commerce, 5285 Port Royal Rd., Springfield, VA 22161 \\ ph: (800) 553-6847 \\ fax: (703) 605-6900 \\ email: orders@ntis.fedworld.gov \\ online ordering: http://www.ntis.gov/ordering.htm
}

This document was printed on recycled paper.

$(9 / 2003)$ 


\title{
Uranium in the Near-Shore Aquatic Food Chain: Studies on Periphyton and Asian Clams
}

\author{
A.L. Bunn \\ T.B. Miley \\ P.W. Eslinger \\ C.A. Brandt \\ B.A. Napier
}

December 2007

Prepared for

the U.S. Department of Energy

under Contract DE-AC05-76RL01830

Pacific Northwest National Laboratory

Richland, Washington 99352 



\section{Summary}

The benthic aquatic organisms that are found in the near-shore environment of the Columbia River are the first biological receptors that can be exposed to groundwater contaminants coming from the U.S. Department of Energy's Hanford Site. These benthic organisms are attached to the river substrate (e.g., periphyton) or move around within the substrate (e.g., clams) but are not found up in the water column (e.g., phytoplankton or fish like bass). The primary contaminant of concern in the former nuclear fuels processing area at the Site, known as the 300 Area, is uranium. Currently, there are no national clean up criteria for uranium and ecological receptors. This report summarizes efforts to characterize biological uptake of uranium in the food chain of the benthic aquatic organisms and provide information to be used in future assessments of uranium and the ecosystem.

Uranium, as it enters the Columbia River from the groundwater, is likely to complex with the ions and other water quality characteristics, and the uranium complexes may be associated with the accumulation of uranium in the aquatic biota. The accumulation of uranium in the periphyton community and Asian clams (Corbicula fluminea) was investigated using laboratory studies, field measurements and ecological risk models. The general conclusions as a result of these investigations are listed below, with additional detail provided in relevant sections in the main body of this report.

\section{Laboratory Studies}

- Periphyton accumulates uranium readily. However, at concentrations as high as $100 \mu \mathrm{g} / \mathrm{L}$ uranium, there was no indication of an impact to the community from the presence of uranium based on biomass and chlorophyll content.

- Asian clams accumulate uranium readily, but the rate of accumulation is dependent on water concentration.

- Accumulation and loss of uranium in the soft tissue of clams changes based on exposure history. In pulsed-exposure studies where the accumulation was evaluated based on short- and long-term pulse of uranium, the concentration in the clam's soft tissues changed based on how long the tissues were exposed to uranium.

\section{Field Measurements}

- Asian clams represent one of the most common aquatic species collected in the Hanford Reach of the Columbia River. Periphyton has only been collected by a few programs.

- Environmental media (e.g., river water and sediment) have been collected frequently, and offer a basis for evaluation in ecological risk assessments.

\section{Ecological Risk Modeling}

- Ecological Contaminant Exposure Model (ECEM) has been developed for the evaluation of risk to the aquatic food chain of the Hanford Reach of the Columbia River.

- Parameters for evaluating risk using ECEM were assessed using values from literature sources, as well as calculations from laboratory studies and field measurements. The range and distribution of biological concentration factors (BCFs) from these three sources varied in range and distribution. Results indicated that additional improvements to ecological modeling results would benefit from further refining of parameters other than BCF. 



\section{Acknowledgement}

We would like to thank the many people who contributed to this report. James Becker and Amanda Stegen have provided support for ecological modeling. Lynn Bisping provided the measured field values from the Surface Environmental Surveillance Program. Jill Brandenberger provided analytical services for the laboratory samples. Robin Durham, Bradley Fritz, Donald Mendoza, Bev Miller, Brian Miller, Jack Small, Danielle Saunders, Tara Schwartz, Amanda Stegen, and Cherylyn Tunnicliffe worked through cold conditions during field collection of biological samples and long hours in the laboratory during exposure studies. 



\section{Contents}

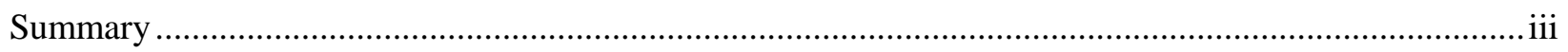

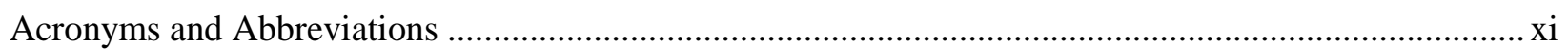

1.0 Introduction to Uranium in the Near-shore Hanford Environment .............................................. 1.1

2.0 Background on Uranium and Aquatic Food Chain ................................................................... 2.1

2.1 Speciation and Geochemistry of Uranium in Saturated Systems ....................................... 2.1

2.2 Aquatic Food Chain of the Columbia River...................................................................... 2.2

3.0 Laboratory Assessments of Periphyton and Corbicula ............................................................... 3.1

3.1 Uranium Uptake by the Periphyton Community …................................................................ 3.1

3.1.1 Methods and Materials for Periphyton Studies ....................................................... 3.1

3.1.2 Results for Periphyton Studies .............................................................................. 3.3

3.2 Uranium Uptake by Asian Clams............................................................................. 3.5

3.2.1 Uptake and Depuration Studies with Asian Clams ................................................ 3.6

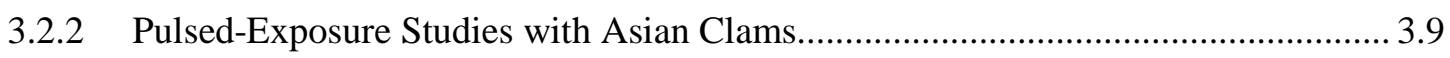

3.3 Calculation of BCFs from Laboratory Studies .................................................................. 3.12

4.0 Field Monitoring Data for Uranium in the Aquatic Environment ................................................. 4.1

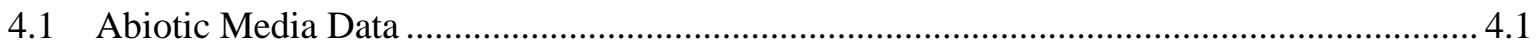

4.2 Calculation of Exposure Point Concentrations................................................................... 4.1

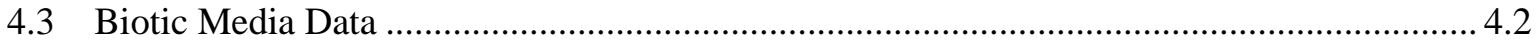

$5.0 \quad$ Ecological Contaminant Exposure Model .................................................................................... 5.1

5.1 Background for Ecological Risk Assessment Modeling ..................................................... 5.1

5.2 Structure of the Ecological Contaminant Exposure Model .................................................. 5.3

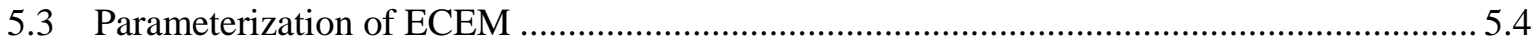

6.0 Comparison of Measured Field Values to Laboratory Values Using ECEM............................... 6.1

6.1 Measured vs. Modeled Uranium Body Burdens in Asian Clams......................................... 6.1

6.2 Application of Laboratory Exposure Studies to Modeled Body Burdens in Asian Clam ...... 6.1

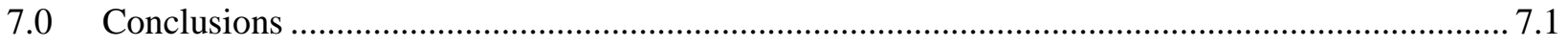

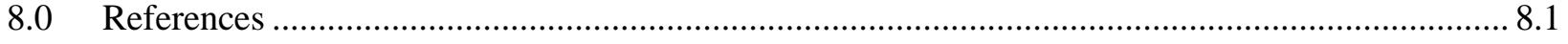

Appendix A - Data for Modeling Uptake by Aquatic Food Chain ....................................................... A.1

Appendix B - Discussion of the Mathematical Basis for the Ecological Chemical Exposure Model.......B.1 


\section{Figures}

1.1 U.S. Department of Energy’s Hanford Site, Washington ............................................................ 1.3

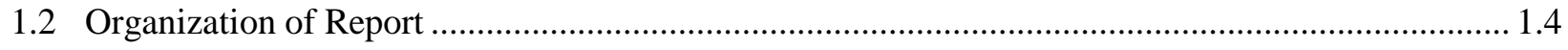

2.1 Eh-pH Diagram Showing the Dominant Aqueous Species of Uranium .......................................... 2.2

2.2 Aquatic and Riparian Food Chain for the Hanford Reach of the Columbia River .......................... 2.3

2.3 Simplified Food Chain in the Benthic Environment....................................................................... 2.4

2.4 Diagram of the Groundwater/River Water Zone of Interaction...................................................... 2.4

2.5 Columbia River Substrate Showing the Close Association of Corbicula and Periphyton ................ 2.6

3.1 Periphyton Covering the Upper Surface of Cobble From the Columbia River ............................... 3.1

3.2 Periphyton on Glass Microscope Slide Collected from Uranium Exposure System ......................... 3.3

3.3 Uptake and Depuration of Uranium by Periphyton based in Laboratory Exposure Studies ............. 3.4

3.4 Periphyton Biomass Measurements From Uranium Uptake and Depuration Laboratory

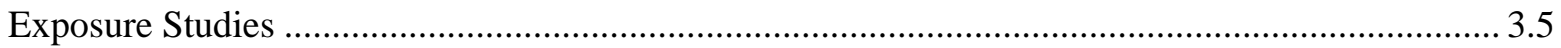

3.5 Chlorophyll Measurements From Uranium Uptake and Depuration Laboratory

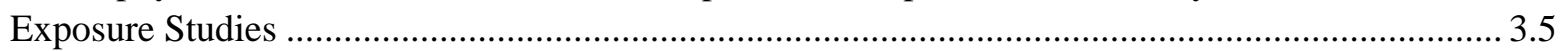

3.6 Uranium Uptake Exposure Studies With Corbicula ................................................................. 3.6

3.7 Concentrations of Uranium in Water and Clam Soft Tissue in the Uptake and Depuration Studies.

3.8 Concentration of Uranium in Water and Soft Tissue of Clams in the Short-Term PulsedExposures With Asian Clams

3.9 Concentration of Uranium in Water and Soft Tissue of Clams in the Long-Term PulsedExposures With Asian Clams

3.10 Concentration of Uranium in Soft Tissue of Clams for Both the Short- and Long-Term Pulsed-Exposures With Asian Clams ...

3.11 Periphyton BCF vs. Water Concentration Based on Laboratory Exposure Studies ....................... 3.12

3.12 Corbicula BCF vs. Water Concentration Based on Laboratory Exposure Studies.

4.1 Uranium Concentration in Soft Tissues From Corbicula Collected in the Hanford Reach of the Columbia River.

5.1 Representation of the Accumulation of Contaminants and the Process for Determining the Total Body Burden in Aquatic Species Using ECEM.

6.1 Comparison of Uranium Body Burden in Asian Clam, Measured and Modeled ............................. 6.2

6.2 Comparison of Uranium Body Burden in Corbicula with Laboratory-Derived Parameters 


\section{Tables}

3.1 Environmental Conditions for the Periphyton Laboratory Studies.

3.2 Exposure Concentrations in the Water Phase for Uranium Uptake by Periphyton .......................... 3.3

3.3 Environmental Conditions for the Asian clam Laboratory Studies ................................................. 3.7

3.4 Exposure Concentrations in the Water Phase for Uranium Uptake by Clams................................. 3.7

4.1 Summary of Abiotic Media Data for Uranium in Pore Water, Surface Water and Sediment ........... 4.1

5.1 Description of Parameters Associated With the ECEM Model for Assessing Uranium in the

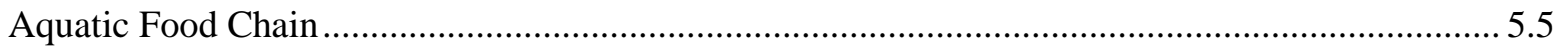

5.2 Values for the Non-Stochastic Parameters in the ECEM Model for Assessing Uranium in the

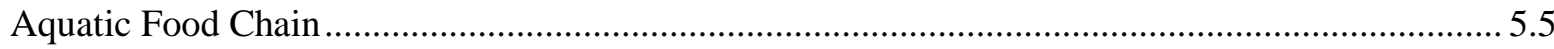

5.3 Values for the Stochastic Parameters the ECEM Model for Assessing Uranium in the Aquatic Food Chain 

Acronyms and Abbreviations 



\subsection{Introduction to Uranium in the Near-Shore Hanford Environment}

The Hanford Site, a U.S. Department of Energy (DOE) complex, occupies an area of about $1517 \mathrm{~km}^{2}$ (about $586 \mathrm{mi}^{2}$ ) in south central Washington State (Figure 1.1). The Site has restricted public access and provides a buffer for the areas that are actively being remediated or used for storage of nuclear materials, waste treatment, and waste storage and/or disposal. The Columbia River flows through the northern part of the Hanford Site and, turning south, forms part of the Site's eastern boundary. The portion of the river that flows through the Site is known as the Hanford Reach, which extends for 94 km (58 mi) Priest Rapids Dam downstream to the head of Lake Wallula, created by McNary Dam, near the city of Richland, Washington. Flows through the Hanford Reach fluctuate significantly and are controlled primarily by releases from upstream storage dams. From 1991 through 2000, the average flow rate was about $3360 \mathrm{~m}^{3} / \mathrm{s}\left(120,000 \mathrm{ft}^{3} / \mathrm{s}\right)$. Daily average flow rates varied from 1,250 to $7,730 \mathrm{~m}^{3} / \mathrm{s}(44,200$ to $273,000 \mathrm{ft}^{3} / \mathrm{s}$ ) during 2006. As a result of fluctuation in discharges, the depth of the river varies significantly over time. The river stage (water-surface level) may change along the Hanford Reach by up to 3 m (10 ft) within a few hours (Becker 1990; Duncan 2007; Poston et al. 2007; Zachara 2005).

The Hanford Site was established in 1943 to produce plutonium for nuclear weapons. The Site was divided into a number of operational areas: 100, 200, 300, and 400 Areas (Figure 1.1). During the plutonium production era, the 300 Area was primarily for research and development activities, and contains former nuclear fuel fabrication facilities, fuel research laboratories, liquid effluent disposal sites (e.g., process trenches, process ponds), and several solid waste burial grounds. As a result of the fuel fabrication activities, waste uranium was discharged to disposal ponds and trenches in the 300 Area and uranium is the primary contaminant of concern in groundwater in the 300 Area (Duncan 2007; Hartman et al. 2004; Poston et al. 2007; Zachara 2005).

One issue associated with remediation and environmental management of the former production areas at the Hanford Site is the selection of cleanup criteria. Under the Comprehensive Environmental Response, Compensation, and Liability Act (CERCLA), all remedial actions must be protective of human health and the environment and comply with applicable or relevant and appropriate requirements (ARARs) unless a waiver is justified. Cleanup levels for response actions under CERCLA are typically developed based on site-specific risk assessments (ARARs). The determination of whether a requirement is applicable, or relevant and appropriate, is made on a site-specific basis (40 CFR 192). In the 300 Area, the interim Record of Decision for the 300-FF-5 Groundwater Operable Unit was based on the lowest established criteria for protection of human health and the environment (EPA 1996). EPA's human health drinking water standard was chosen (30 $\mu \mathrm{g} / \mathrm{L})$ (EPA 2000) since there was no other standard for protection of the environment (EPA 1996). Currently, there are no Federal or Washington State criteria for uranium in water and protection of ecological receptors.

The U.S. Environmental Protection Agency (EPA) has not established criteria for protection of aquatic organisms from exposure to uranium because, at this time, there has not been sufficient research conducted to meet its protocol for establishing a U.S. National Ambient Water Quality Criteria (AWQC) for Protection of Aquatic Life (Kent et al. 2003). Benchmarks like the AWQC are used for establishing site-specific clean up levels, such as for hexavalent chromium in the 100 Areas of the Hanford Site. 
There are peer-reviewed publications that have established criteria for uranium and the protection of aquatic receptors. Suter (1996) reviewed the available aquatic biota toxicity literature on uranium, and used a method to calculate values that are protective of aquatic life using less data than is required for the AWQC. He calculated concentrations to be protective for all aquatic life based on chronic (long-term) exposures (1.42 $\mu \mathrm{g} / \mathrm{L})$ and acute (short-term) exposures (33.5 $\mu \mathrm{g} / \mathrm{L})$. Sheppard et al. (2005) also reviewed peer-reviewed literature and calculated predicted no-effect concentrations (PNEC) for chemical toxicity of uranium to freshwater plants and invertebrates $(5 \mu \mathrm{g} / \mathrm{L})$. Efforts to calculate a PNEC for freshwater fish showed that water hardness provided protection to fish from effects of exposure to uranium. Therefore, the PNEC values for fish in very soft waters $\left(<10 \mathrm{mg} / \mathrm{L} \mathrm{CaCO}_{3}\right)$ has a lower uranium concentrations than the PNEC value for hard waters (> $100 \mathrm{mg} / \mathrm{L} \mathrm{CaCO})_{3}(4000 \mu \mathrm{g} / \mathrm{L}$ and 23,000 $\mu \mathrm{g} / \mathrm{L}$ uranium, respectively).

The results of numerous studies of uranium and aquatic organisms indicate that site-specific characteristics will be relevant to the selection of a cleanup level for the protection of the environment. Determining the level of uranium that is associated with the lowest observed adverse effects level or no observable adverse effects level will likely be different for organisms at the groundwater/river interface (e.g., algae, clams, and insects) compared to organisms that are found up in the water column (e.g., fish). Water quality characteristics of the groundwater and river water (e.g., water hardness) will also change the uranium concentration that is likely to cause an effect to aquatic life.

The research described in this report was directed to understand how the aquatic organisms at the groundwater/river interface in the Columbia River accumulate uranium, and to determine under sitespecific conditions the uranium values that are important to ecological risk assessments of aquatic organisms. This work was completed as part of the Biological Exposures Studies Task of the Remediation and Closure Science Project led by Pacific Northwest National Laboratory for the DOE's Richland Operations Office and Fluor Hanford, Inc.

The objectives of this report are: 1) to summarize laboratory studies on the accumulation of uranium in periphyton and Asian clams, and 2) to parameterize ecological risk models of uranium in the aquatic food chain using laboratory and field measured values. Figure 1.2 illustrates how the report is organized to support these objectives. Section 2 provides background information about uranium and the aquatic food chain that is relevant to this report. Section 3 is a summary of the laboratory assessments for the accumulation of uranium in periphyton and clams. Section 4 includes the measured, field monitoring data for uranium in pore water, surface water, sediment and clams along the shoreline of the 300 Area that has been collected by the Surface Environmental Surveillance Program. Section 5 discusses the mathematical basis for the modeling of uranium uptake by aquatic organisms, and the default parameters for the Ecological Contaminant Exposure (ECEM) model. Section 6 is a comparison of the modeled body burdens to the measured biota from the Columbia River using peer-reviewed literature parameters and the laboratory exposure parameters. This section also includes a discussion of laboratory values in ECEM and a comparison of modeled clam body burden results to the measured field values. Finally, Section 7 discusses a summary of the recommendations for future assessments of uranium in the aquatic food chain. 


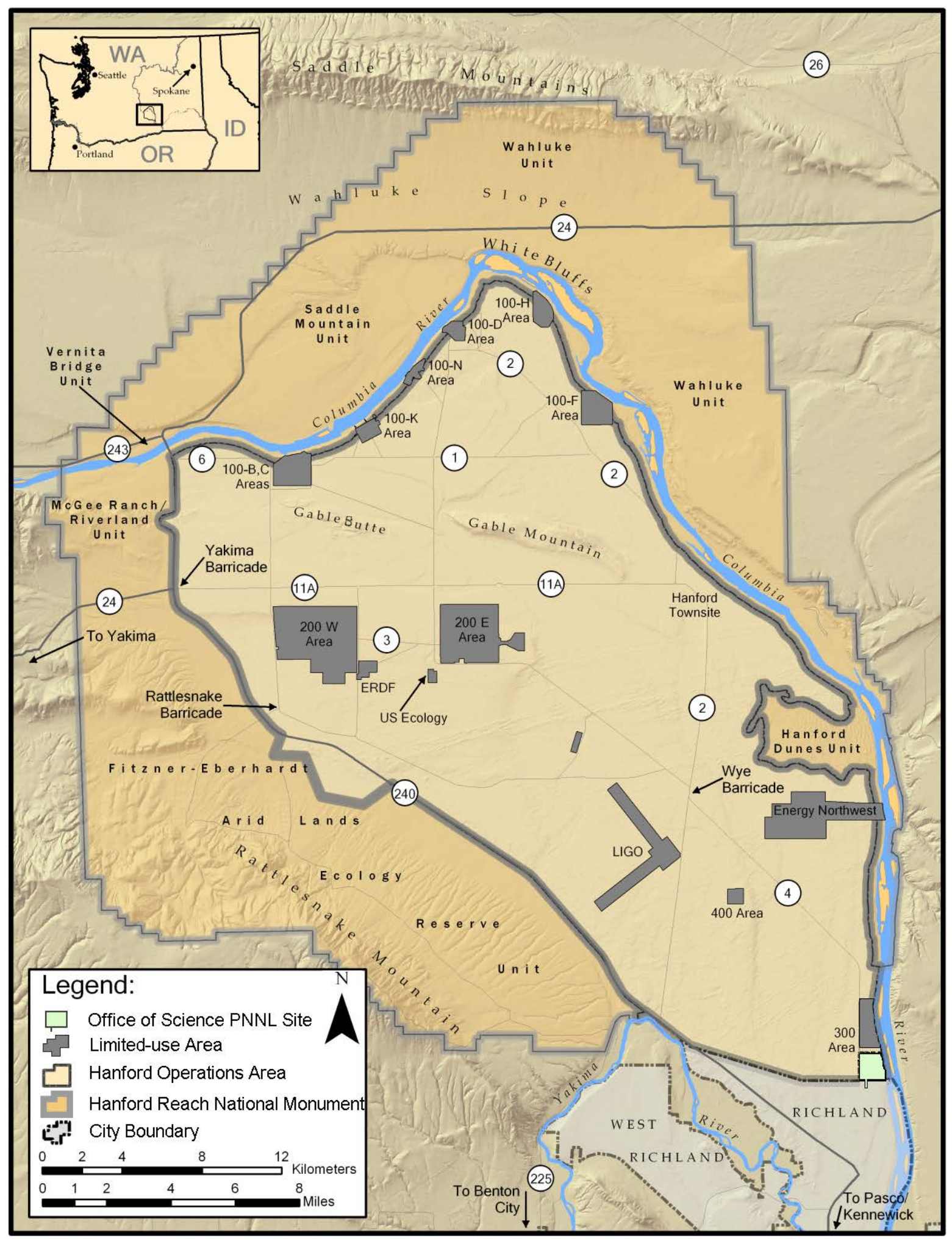

Figure 1.1. U.S. Department of Energy’s Hanford Site, Washington 


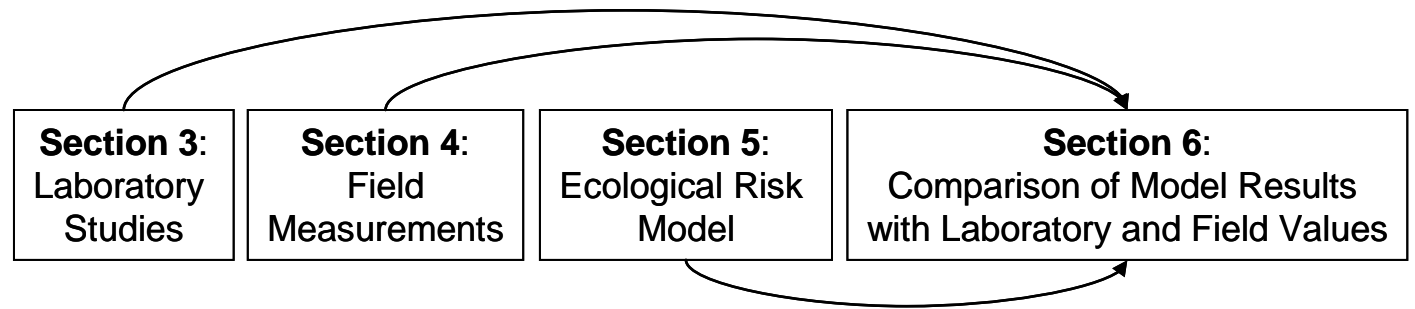

Figure 1.2. Organization of Report 


\subsection{Background on Uranium and Aquatic Food Chain}

This section discusses uranium in saturated systems and the aquatic food chain for the near-shore environment along the Hanford Reach of the Columbia River. Uranium chemistry in systems like natural waters is still being investigated. What is known today clearly has implications on the accumulation of uranium in biota.

\subsection{Speciation and Geochemistry of Uranium in Saturated Systems}

Understanding how a living organism interacts with uranium includes understanding how uranium itself has been introduced to the environment and how the metal is moving in groundwater and into the Columbia River. Uranium fate and transport at the Hanford Site continues to be the subject of numerous studies that are on-going. The complexity of uranium chemistry and its fate and transport at the Hanford Site can be seen through the changes in strategies for cleaning up the 300 Area and the different approaches for the CERCLA Record of Decision in that region from the interim decision in 1996 (EPA 1996) for natural attenuation to the present where active treatment options are being considered (EPA 2001a; DOE 2005). Zachara et al. (2007) provides an overview of the efforts to develop a comprehensive integrated conceptual model of uranium geochemistry at the Hanford Site.

In saturated and aqueous environments, uranium can exist in the $+3,+4,+5$, and +6 oxidation states. The environmental chemistry of uranium is complex, and is dominated by two stable-valence states [U(IV) and U(VI)] depending on redox conditions. Under oxidizing conditions (e.g., waters with dissolved oxygen greater than $1 \mathrm{ppm})$, uranium exists in the hexavalent state [U(VI)] as the uranyl cation $\left(\mathrm{UO}_{2}{ }^{2+}\right)$. Under reducing conditions (e.g., Eh less than approximately $\left.0.25 \mathrm{~V}\right)$, uranyl transforms to the tetravalent state $[\mathrm{U}(\mathrm{IV})]$ as the insoluble-uranous cation $\left(\mathrm{U}^{4+}\right)$ (Zachara et al. 2007).

Zachara et al. (2007) has found that uranium speciation, as well as fate and transport of uranium, is dependent on the waste and geochemical conditions at the Hanford Site. Most environmental releases of dissolved uranium at Hanford were dominated by U(VI) based on what is known about how uranium was processed at Hanford and how uranium chemical reacts in environmental conditions. Zachara et al. concludes that "to large degree, the behavior of contaminant uranium at the Hanford Site as a reactive solute is dominated by the geochemistry of the uranyl ion $\left(\mathrm{UO}_{2}{ }^{2+}\right)$." Efforts to develop reactive transport models to predict the long-term fate and mobility of uranium contamination in both the unsaturated and saturated zones requires further characterization of the complexes that uranium has formed within the system.

With that said, what happens to the uranium in groundwater at the groundwater/river interface and in the Columbia River is dominated by the conditions of the river water itself. Figure 2.1 is an Eh-pH diagram (or Pourbaix), and illustrates the speciation of uranium in natural waters. Because anions do not readily adsorb to mineral surfaces at basic $\mathrm{pH}$ conditions, the formation of anionic U(VI) carbonate complexes at $\mathrm{pH}$ values greater than 6 result in an increase in $\mathrm{U}(\mathrm{VI})$ solubility, decreased $\mathrm{U}(\mathrm{VI})$ adsorption, and thus increased mobility of uranium. The Hanford vadose zone and upper unconfined aquifer environments contain adequate carbonate concentrations to have these uranyl carbonate complexes dominate the aqueous speciation of uranium (Robertson et al. 2003).

In the Columbia River and other natural water systems, uranium likely also forms stable complexes with other naturally occurring inorganic and organic ligands (Robertson et al. 2003; Sheppard et al. 2005). For example, at a range of $\mathrm{pH}$ in the Columbia River (and in the exposure studies discussed in this report, 
Figure 2.1) between 7 and 9, $\mathrm{UO}_{2}{ }^{2-}$-phosphate complexes $\left[\mathrm{UO}_{2} \mathrm{HPO}_{4}{ }^{\circ}(\mathrm{aq})\right.$ and $\left.\mathrm{UO}_{2} \mathrm{PO}_{4}{ }^{-}\right]$could be important in aqueous systems when the total concentration ratio $\mathrm{PO}_{4}($ total $) / \mathrm{CO}_{3}$ (total) is greater than 0.1 (Sandino and Bruno 1992). Complexes with sulfate, fluoride, and possibly chloride are potentially important uranyl species where concentrations of these anions are high. Organic complexes may also be important to uranium aqueous chemistry, thereby increasing their solubility and mobility. Uranium complexes with these natural ligands have been attributed to the greater "effective charge" of the uranyl ion compared to other divalent metals (Kim 1986; Robertson et al. 2003).

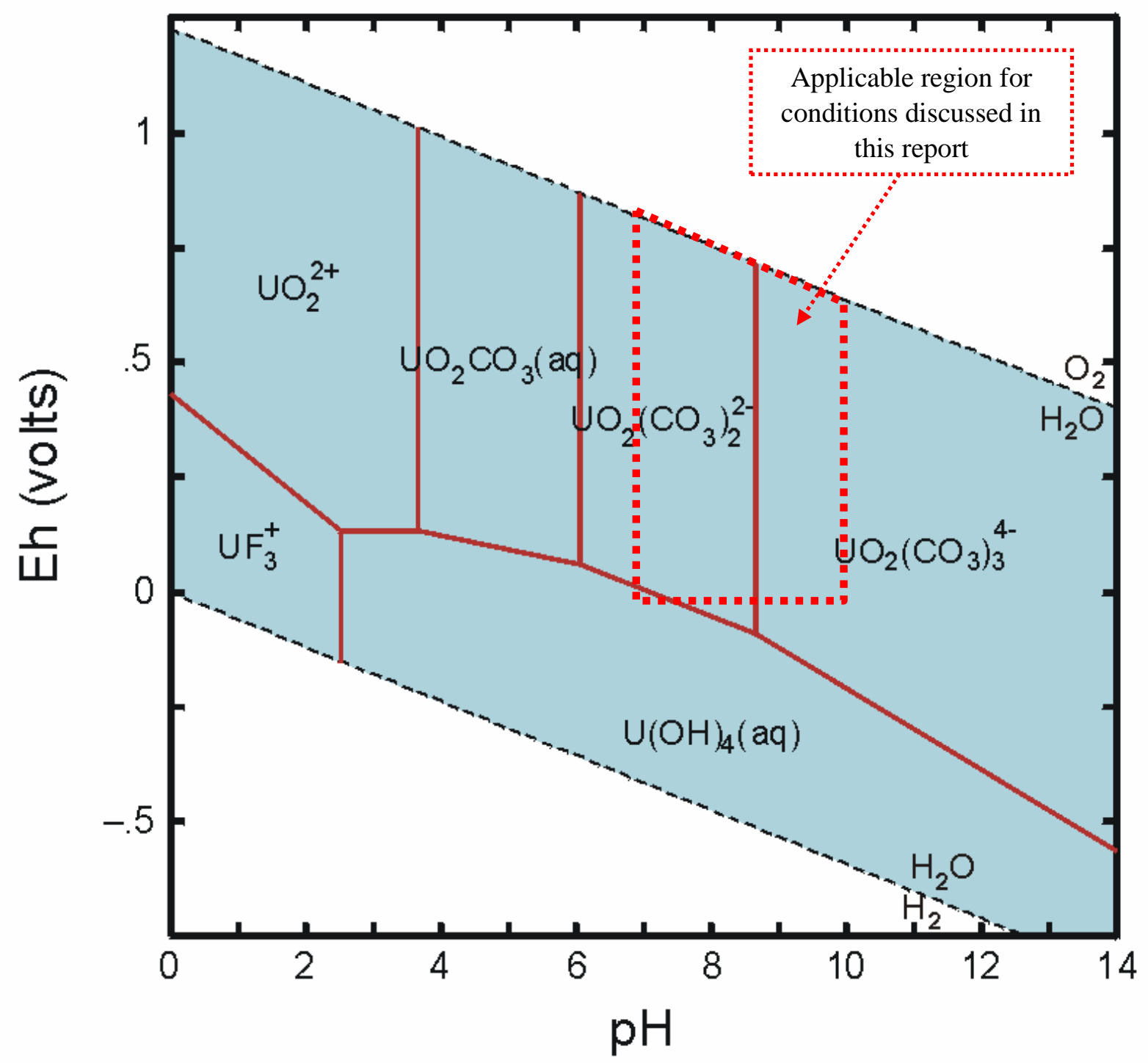

Figure 2.1. Eh-pH Diagram Showing the Dominant Aqueous Species of Uranium

\subsection{Aquatic Food Chain of the Columbia River}

The aquatic life at the groundwater/river interface is known as the benthic community. The community at this interface includes organisms that are attached (sessile), as well as organisms that can move yet still remain on the river substrate. The greatest diversity of organisms in the benthic environment is associated with primary production of the aquatic food chain, where sunlight and chemical ions are converted into energy. This is the attached algal community known as periphyton. The aquatic 
food chain is connected to the ecosystem of the Hanford Site around the Columbia River. Figure 2.2 illustrates the food chain for the aquatic and riparian food chain (DOE 1998). A simplified food chain associated with the benthic community would include primary producers (periphyton), primary consumers (clams, snails and insect larvae), and fish (Figure 2.3). This report is focusing on the primary producers (periphyton) and first order consumers (clams) in the food chain.

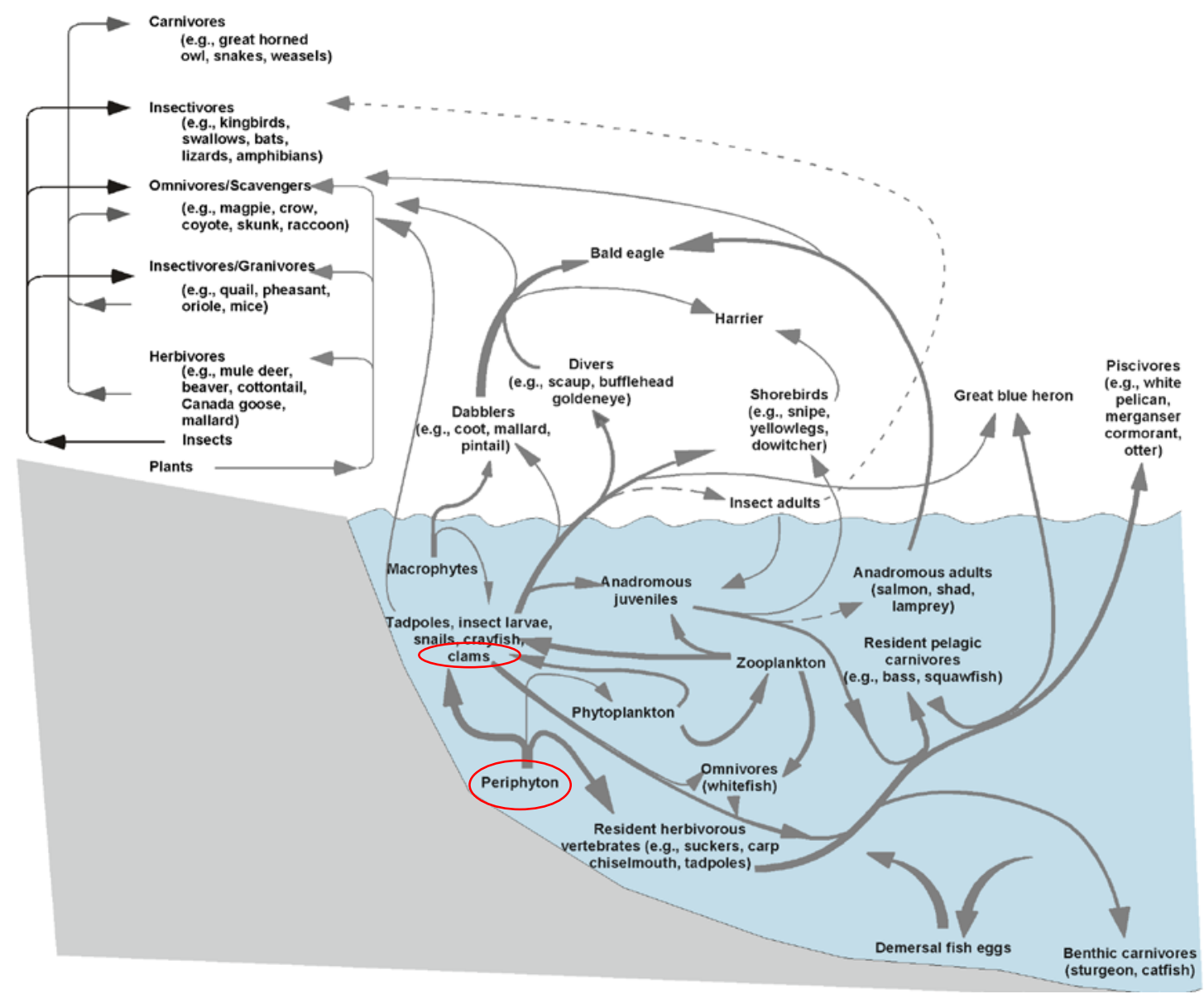

Figure 2.2. Aquatic and Riparian Food Chain for the Hanford Reach of the Columbia River

The groundwater flow system beneath the Hanford Site represents a primary environmental pathway for contaminant movement away from source areas (Zachara et al. 2007). This pathway ultimately discharges into the Columbia River. Near the river, the groundwater flow system is influenced by the river flow system in a zone of groundwater/river interaction (ZOI) (Peterson and Connelly 2001). The principal features and terminology associated with the ZOI are illustrated in Figure 2.4.

Benthic aquatic organisms are the first receptors in the river environment to receive groundwater contamination. These organisms can accumulate contamination from direct exposure to the contaminant in water and in sediment. Ingestion of contamination in water, sediment or accumulated in other organisms is another means of accumulation in aquatic organism. As Figure 2.2 illustrates, the food chain from the benthic organisms throughout the river and riparian environment involves numerous species. Past assessments of the Columbia River have shown that the greatest ecological risk from Hanfordderived contaminants is to the benthic aquatic organisms and those organisms with the greatest consumption of those at the sediment/water interface (DOE 1998). 


\title{
Secondary Consumers
}

\author{
Primary Consumers
}

Primary Producers
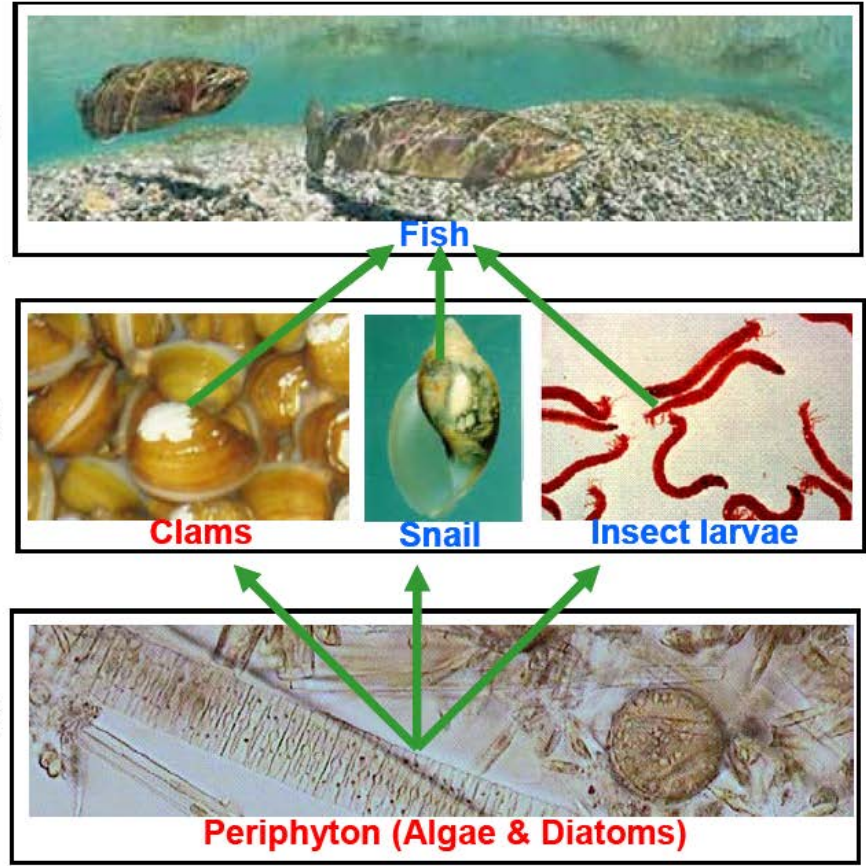

Figure 2.3. Simplified Food Chain in the Benthic Environment

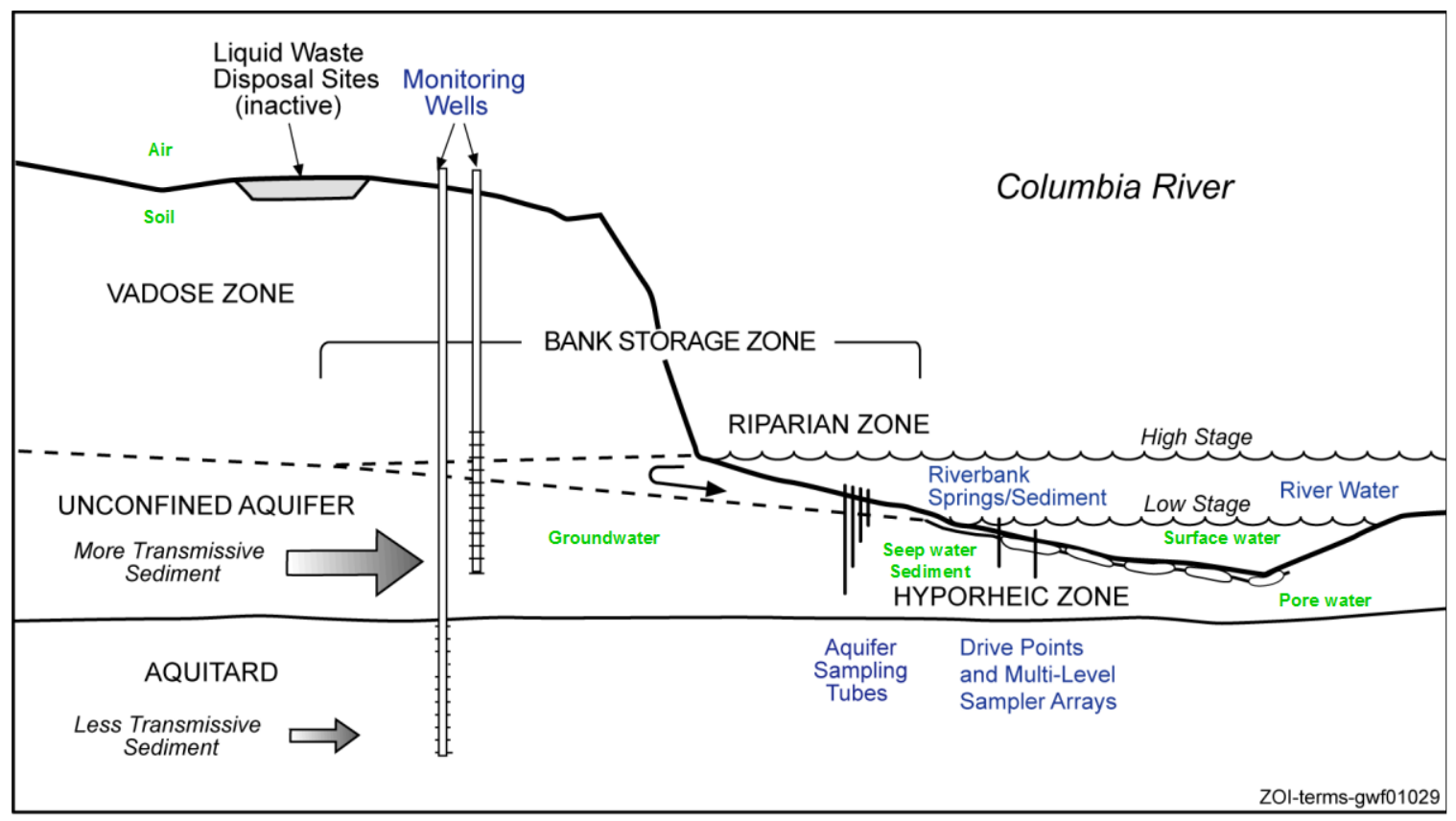

Figure 2.4. Diagram of the Groundwater/River Water Zone of Interaction.

The periphyton community and Asian clams (Corbicula fluminea) were chosen for further in the laboratory uptake studies. Periphyton communities are benthic microbial biofilms that are important as primary producers (most of the community members are phototrophic) and food sources in aquatic systems (Cushing and Allan 2001; Palms et al. 2007). Algae, diatoms, fungi, and bacteria make up the 
biofilm community, along with associated protozoans and small multicellular animals. Ubiquitous in river ecosystems, periphyton plays an important role in nutrient cycling and trophic transfer of nutrients (Arnon et al. 2007) and forms the base of food chains (Cushing and Allan 2001; Vadeboncoeur et al. 2005). About $95 \%$ of the periphyton community is composed of microorganisms that acquire their energy for growth and reproduction from chemicals or the sun (Bunn et al. 2007). Contaminants can accumulate in periphyton by adsorption to the high surface area of the organisms in the biofilm (through physical/chemical processes) as well as adsorption by the organisms. Adsorption can be through physical/chemical processes that do not require the cell to expend energy and biological processes that do require the cell to expend energy. The above factors, and the sessile nature of periphyton communities, make periphyton a potentially important indicator of local ecosystem conditions (Guckert et al. 1992; Hill et al. 2000).

Corbicula fluminea is an exotic species from Asia that was first discovered in the U.S. in 1935 in the Columbia River (Cherry and Soucek 2007). In ponds, lakes or slow moving water, these clams are known to consume phytoplankton, periphyton, and other small benthic invertebrates, e.g., Daphnia (a water flea) and juvenile Hyallela (an amphipod). In the Columbia River, the clam is found in between the cobble substrate on the river bed and is closely associated with the periphyton community (Figure 2.5). Observations of the clams in during laboratory studies in this report show that the clams will scrape periphyton with their foot to release particulates. This action is known as pedal-feeding, where cilia on the foot draw particles (including periphyton organisms) into the clam's mantle cavity and ultimately ingested (Cushing and Allan 2001; Cherry and Soucek 2007). Thus, Asian clams can feed on particles in suspension using its siphons (filter feeding) as well as through pedal feeding. Cherry and Soucek (2007) state that Asian clams grow at a faster rate with pedal-feeding than it would by filter feeding alone.

Clams and mussels are considered good biological indicators of metal contaminants as well as other pollutants (Farris and Van Hassel 2007). Cherry and Soucek (2007) indentified ten criteria for use of an clams and mussels as an effective monitor for metal contamination based on the work by Philips (1977). The criteria include:

- The organism accumulate pollutants without suffering mortality;

- The organism must be sedentary;

- The organism's life span must be sufficient to allow for sampling more than one year class;

- The organism must be abundant in the study region;

- The size of the organism must be adequate to allow tissue samples for contaminant analysis;

- The organism must be easy to collect and hardy enough to survive in the laboratory;

- The organism must tolerate brackish water;

- High metal concentration factor should be exhibited by the organism; and

- Correlation should exist between metal contents and those of the surrounding water under all conditions.

While not all of these criteria are relevant to studies in the Columbia River, a case can be made that Asian clams fit most of them. Clams have often been collected for analysis of metal content by programs monitoring and assessing the Columbia River (DOE 1998 and 2004; Patton et al. 2003; Fritz et al. 2007). 


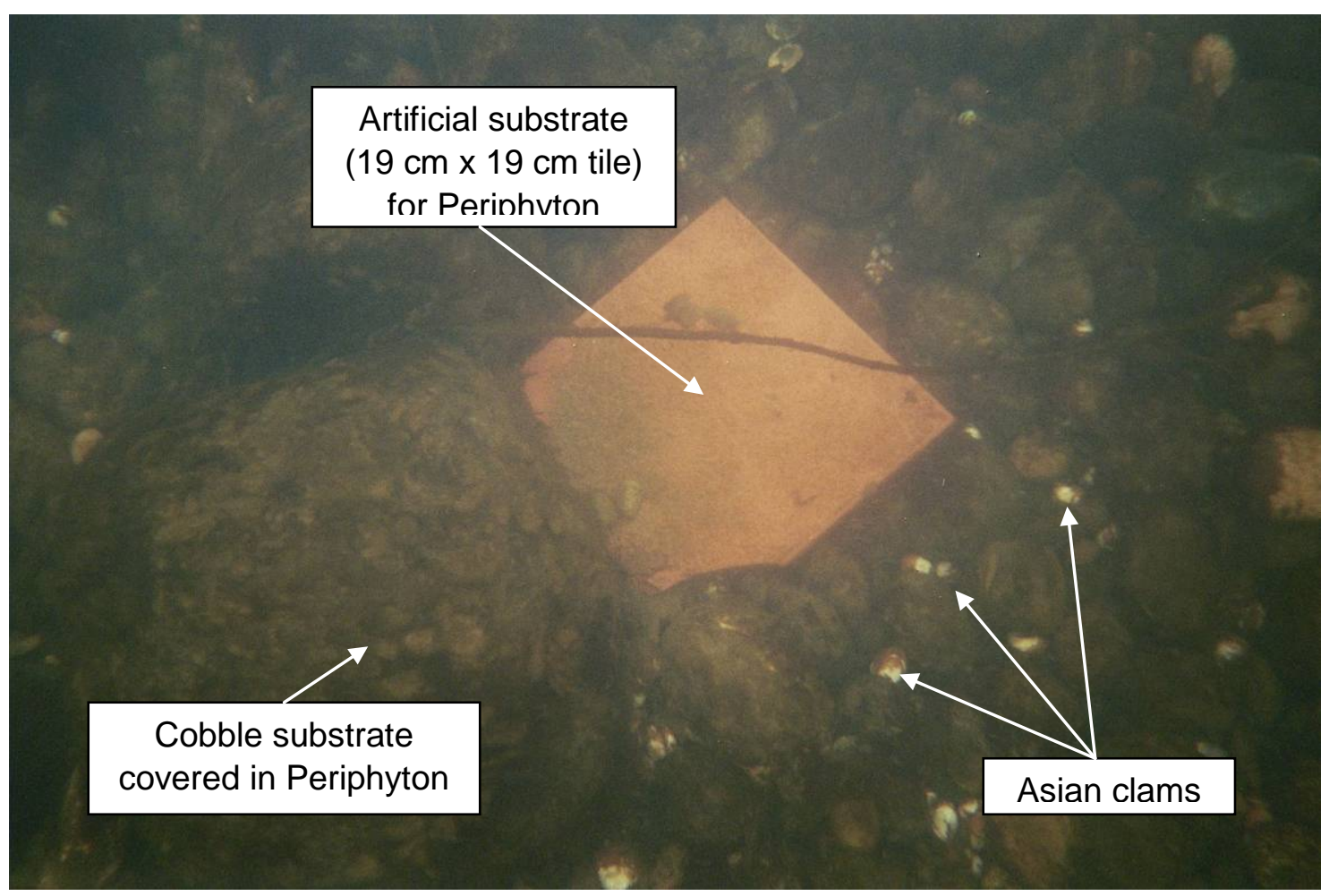

Figure 2.5. Columbia River Substrate Showing the Close Association of Corbicula and Periphyton 


\subsection{Laboratory Assessments of Periphyton and Corbicula}

This section discusses the laboratory exposure studies used to estimate uranium uptake in periphyton and mollusks. This report will investigate the implications to the biological concentration factor (BCF) used in the Ecological Contaminant Exposure Model.

\subsection{Uranium Uptake by the Periphyton Community}

Four experiments were conducted to evaluate uptake and depuration of uranium by the periphyton community. The first experiment was used to as a range finding study to determine the sensitivity of periphyton to uranium and to determine the length of time to reach an apparent equilibrium between the concentration of uranium in the water and the periphyton. The following sections discuss the methods and materials, and the results of the periphyton exposure studies with uranium, with emphasis on the results from the last three exposure studies.

\subsubsection{Methods and Materials for Periphyton Studies}

The source of the periphyton community for this study was the Columbia River, upstream from the Hanford Site (at approximately river mile 390, near Vernita Bridge (Figure 1.1)). Periphyton was collected in situ from river rocks (Figure 3.1). Material scraped from the rocks was returned to the laboratory and passed through stainless steel sieve (U.S. Standard Sieve \#35 and \#20) to remove gravel and large meiofauna. Periphyton biofilms were initiated by adding the periphyton suspension to 13.2-L polycarbonate bins in the growth system plumbed to provide a continuous flow ( $100 \mathrm{~mL}$ min-1) of water from the Columbia River across microscope slides $(50 \mathrm{~mm} \times 75 \mathrm{~mm}$ ) that were held vertical and parallel to the water's flow. River water passed through a $100-\mu \mathrm{m}$ stainless steel strainer and a UV sterilizer system (25 watt) before flowing into the growth system. Full-spectrum lights illuminated the bins over the microscope slides. The periphyton biofilm was allowed to grow on the microscope slides for 30 days prior to moving the microscope slides to the $U$ exposure system. Lighting conditions were the same as in the growth system. Table 3.1 summarizes the environmental conditions for the periphyton studies.

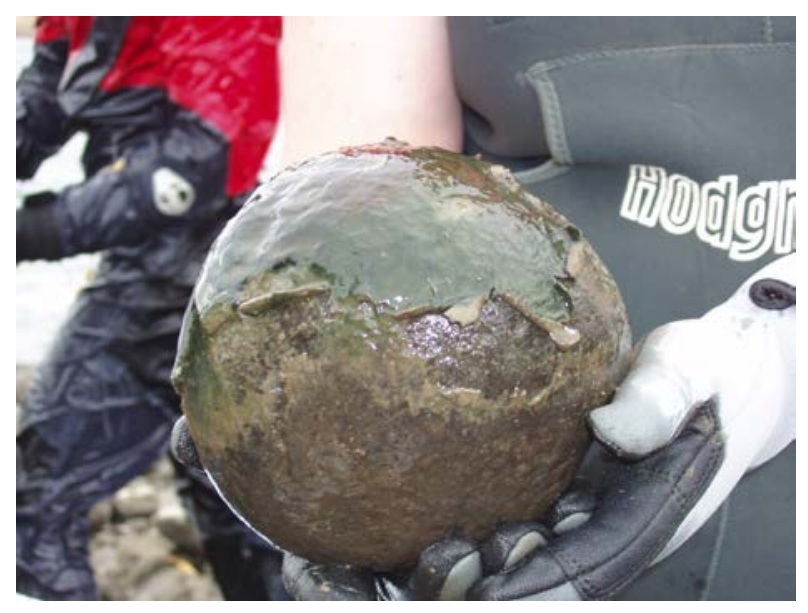

Figure 3.1. Periphyton Covering the Upper Surface of Cobble From the Columbia River 
Table 3.1. Environmental Conditions for the Periphyton Laboratory Studies

\begin{tabular}{||l|c|}
\hline \multicolumn{1}{|c|}{ Environmental Conditions } & Value for Periphyton Studies \\
\hline \hline Light/Dark period & $16 \mathrm{hr} / 8 \mathrm{hr}$ \\
\hline Light Intensity & $5508-9936 \mathrm{lux}$ \\
\hline Air Temperature & $18 \pm 2^{\circ} \mathrm{C}$ \\
\hline Water Temperature & $17.5 \pm 0.5^{\circ} \mathrm{C}$ \\
\hline $\mathrm{pH}$ & $9.16 \pm 0.16$ \\
\hline Hardness & $52 \pm 5 \mathrm{mg} / \mathrm{L}$ as $\mathrm{CaCO}_{3}$ \\
\hline Alkalinity & $45 \pm 10 \mathrm{mg} / \mathrm{L} \mathrm{as} \mathrm{CaCO}_{3}$ \\
\hline Dissolved Oxygen & $9 \pm 1 \mathrm{mg} / \mathrm{L}$ \\
\hline
\end{tabular}

The exposure system used for the laboratory studies consisted of the same polycarbonate bins as in the growth system and were plumbed in groups of four bins. Each group had a common reservoir resulting in a total volume of $40 \mathrm{~L}$ river water for each treatment group. The initial concentrations of uranium in the water for these tests are in Table 3.2. These concentrations were chosen because values up to $150 \mu \mathrm{g} / \mathrm{L}$ uranium have been found in groundwater sampling wells near the edge of the Columbia River (Hartman et al. 2007; Fritz et al. 2007). The source of amended uranium was $\mathrm{UO}_{3}$ dissolved in $0.8 \mathrm{M} \mathrm{HNO}_{3}$ acquired from a certified source at Pacific Northwest National Laboratory, Richland, Washington. Table 3.1 shows the final water concentrations after accumulation into the periphyton biomass for all the studies.

Samples of water and periphyton for each treatment concentration were collected for analysis over time $(0,1.5,6,24,48,72,120,127,145$, and $169 \mathrm{hr})$. Water samples were filtered through a $0.45-\mu \mathrm{m}$ filter to obtain the EPA's operationally defined dissolved fraction (EPA 2001b). The water samples were then acid solubilized by adding $2 \%$ double-distilled nitric acid and heating the samples at $85^{\circ} \mathrm{C}$ for $2.5 \mathrm{hr}$. The samples were analyzed using inductively coupled plasma mass spectrometry (ICP-MS). Instrumental drift was evaluated using certified standards every 10 samples with drift maintained at less than $3 \%$. The method detection limit (MDL) was $0.02 \mu \mathrm{g} / \mathrm{L}$ with analytical accuracy $>98 \%$ and precision $<1 \%$ relative percent difference (RPD).

Triplicate periphyton samples were collected for biomass measurement and uranium analyses at each sampling time. A sample consisted of periphyton growth from across the area of three microscope slides (Figure 3.2). Each replicate sample consisted of periphyton scraped from three randomly selected slides using a razor blade and funneled into a $50-\mathrm{ml}$ sterile centrifuge tube. Then, the slides and funnel were rinsed with river water using up to $15 \mathrm{~mL}$ of $0.45-\mu \mathrm{m}$ filtered river water. Periphyton samples were rinsed with river water to remove extracellular uranium by centrifuging the samples at $18^{\circ} \mathrm{C}$ for $10 \mathrm{~min}$ at $3000 \mathrm{rpm}$, gently resuspending in $15 \mathrm{~mL}$ river water and repeating a total of three times. After rinsing, the pellet was transferred into a pre-weighed glass vial. Periphyton biomass was determined using a modification of Standard Method 10300C (Clesceri et al. 1998). Ashed periphyton samples were placed in glass vials and solubilized using a combination of nitric and hydrofluoric acid in order to destroy all siliceous periphyton structures (e.g., diatom frustules). Digested periphyton samples were analyzed by ICP-MS following the same procedures used for the water samples. Standard reference material International Atomic Energy Agency (IAEA) 140 Fucus spp, was digested and analyzed with the samples with analytical accuracy of $>92 \%$ and precision $<1 \%$ RPD. The MDL was $0.001 \mu g$ g- 1 dry weight periphyton. 
Periphyton samples were also collected for analysis of chlorophyll content at the same time as samples for biomass and uranium analyses. Chlorophyll content was determined based on Standard Method 10300C (Clesceri et al. 1998).

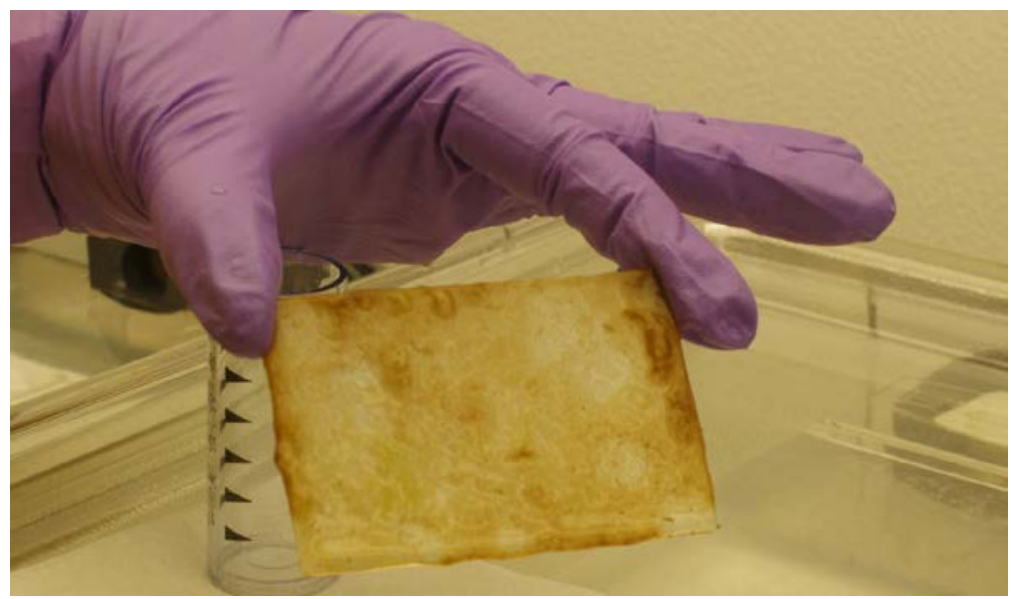

Figure 3.2. Periphyton on Glass Microscope Slide Collected from Uranium Exposure System

Table 3.2. Exposure Concentrations in the Water Phase for Uranium Uptake by Periphyton

\begin{tabular}{|c|c||}
\hline \hline Initial Concentration of Uranium in Water $(\mu \mathrm{g} / \mathrm{L})$ & Final Concentration of Uranium in Water $(\mu \mathrm{g} / \mathrm{L})$ \\
\hline \hline 0.65 & 0.64 \\
\hline 1.37 & 1.69 \\
\hline 1.50 & 1.62 \\
\hline 1.99 & 1.03 \\
\hline 2.93 & 2.95 \\
\hline 5.63 & 6.04 \\
\hline 7.06 & 6.84 \\
\hline 7.31 & 7.09 \\
\hline 10.50 & 4.58 \\
\hline 10.60 & 10.20 \\
\hline 11.30 & 5.39 \\
\hline 11.50 & 9.89 \\
\hline 13.30 & 13.10 \\
\hline 16.50 & 15.60 \\
\hline 33.30 & 14.60 \\
\hline 35.80 & 27.50 \\
\hline 104.00 & 85.20 \\
\hline 105.00 & 40.40 \\
\hline 111.00 & 56.40 \\
\hline
\end{tabular}

\subsubsection{Results for Periphyton Studies}

Uranium was readily sorbed to the periphyton community. The range finding study indicated that an apparent equilibrium between the uranium in the water and in the periphyton was reached within 96 to 120 hrs (data not shown). The uptake period for the subsequent studies was 120 hrs. The depuration time of 48 hrs was chosen based on limits associated with the number of slides covered in periphyton that could be used in the laboratory system available for the studies. 
Figure 3.3 shows the results of uptake of uranium in periphyton during the first 120 hrs of exposure, and depuration in river water for the next $48 \mathrm{hrs}$ (total exposure time was $168 \mathrm{hrs}$ ). The response of the periphyton to uranium is a typical dose-response curve, where the concentration in the tissue is based on the concentration in the water. There is no indication that the periphyton is responding to the uranium based on the uptake and depuration curve.

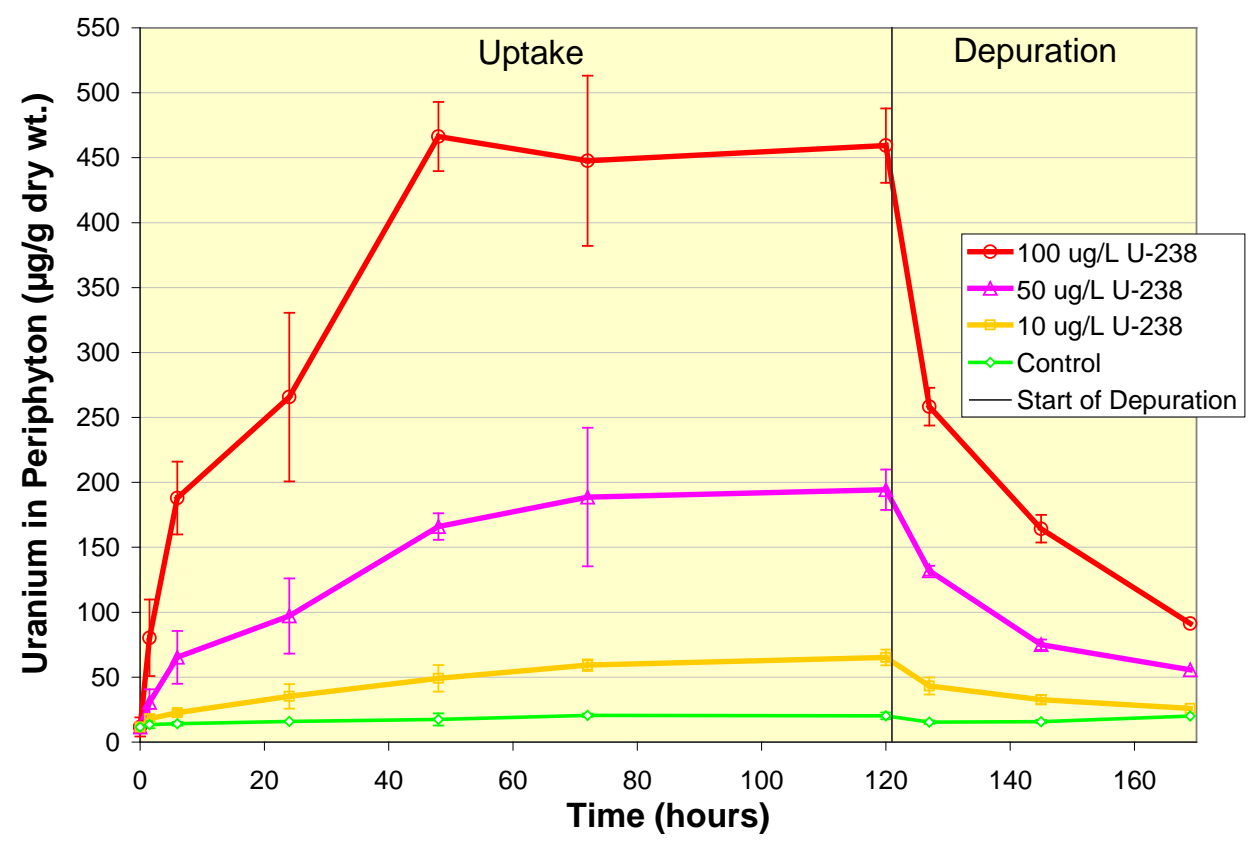

Figure 3.3. Uptake and Depuration of Uranium by Periphyton based in Laboratory Exposure Studies

Other indicators of periphyton response to the presence of uranium also did not indicate a decrease in periphyton productivity. Periphyton biomass (based on dry and ash weight) measurements did not significantly change during uptake or depuration with any of the treatment concentrations (Figure 3.4). Chlorophyll from the periphyton also did not significantly change during uptake or depuration with any of the treatment concentrations (Figure 3.5).

During one exposure study with the periphyton, a pH meter was included in the un-ammended, control treatment to monitor the $\mathrm{pH}$. During one diurnal cycle, $\mathrm{pH}$ values ranged from 8.00 to 9.80. The highest $\mathrm{pH}$ in the water occurred towards the end of the $16 \mathrm{hr}$ light cycle. The $\mathrm{pH}$ decreased to 8 by the end of the dark cycle. While dissolved oxygen and redox potential (Eh) were not measured over this time frame, experience with periphyton experiments indicates that the conditions in the exposure system remained high in terms of dissolved oxygen. Based on Eh-pH diagram (Figure 2.1), the uranium was always U(VI) but the species of the uranium likely fluctuated during the diurnal cycle. 


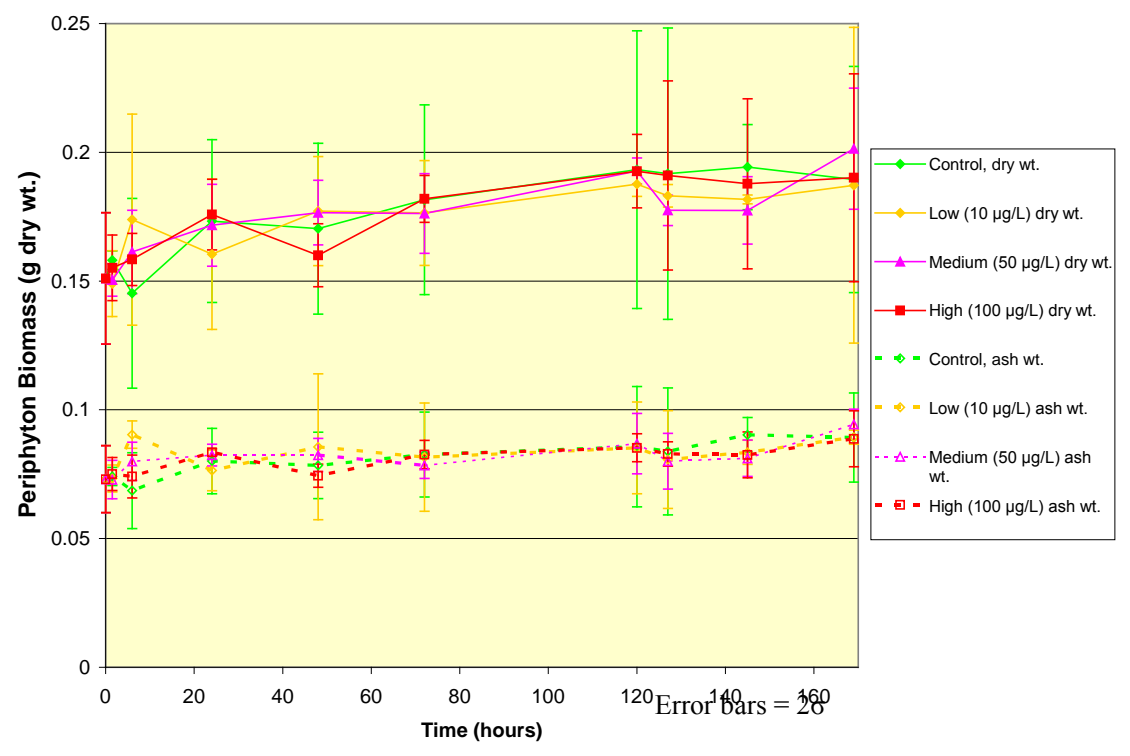

Figure 3.4. Periphyton Biomass Measurements From Uranium Uptake and Depuration Laboratory Exposure Studies

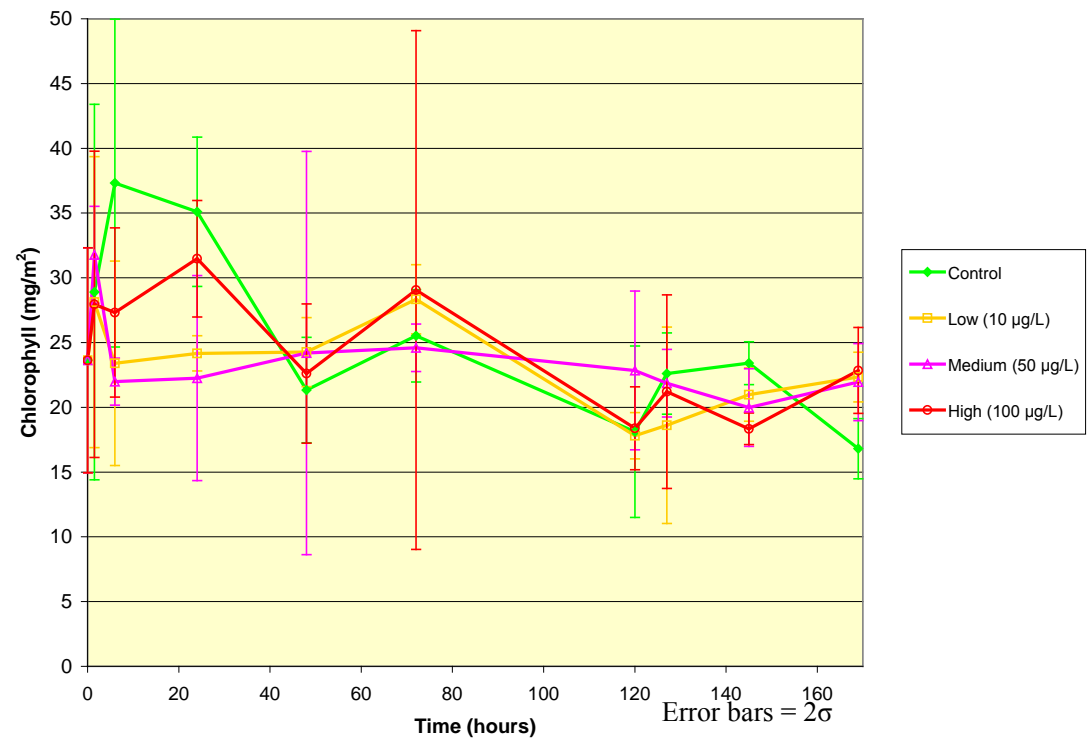

Figure 3.5. Chlorophyll Measurements From Uranium Uptake and Depuration Laboratory Exposure Studies

\subsection{Uranium Uptake by Asian Clams}

Three experiments were conducted to evaluate uptake and depuration of uranium by Asian clams. The first two studies were to evaluate accumulation of uranium in the clam's soft tissue during uptake and depuration phases. The third experiment was used to examine accumulation of uranium in clam soft tissue based on pulsed exposures of uranium, similar to the conditions that the biota in the near-shore 
environment of the Hanford Reach experience as water levels change and mix with groundwater. Clam shells were not analyzed because the duration of the exposure studies was too short for appreciable growth of the clam and any potential for subsequent determination of uranium incorporation into the shell matrix from growth. The following sections discuss the methods and materials, and the results of the Asian clam exposure studies with uranium, with emphasis on the results from the last two exposure studies.

\subsubsection{Uptake and Depuration Studies with Asian Clams}

The first two experiments with Asian clams were performed to understand the accumulation of uranium in the soft tissue of the clams from continuous exposure to uranium (uptake phase) followed with continuous exposure to river water (depuration phase). The first experiment was used to as a range finding study to determine the sensitivity of the clams to uranium and to determine the length of time to reach an apparent equilibrium between the concentration of uranium in the water and the clam's soft tissue. The second experiment was to evaluate uptake and depuration.

\subsubsection{Methods and Materials for Uptake and Depuration Studies with Asian Clams}

Asian clams (Corbicula fluminea) were collected from the Columbia River, upstream from the Hanford Site (at approximately river mile 390, near Vernita Bridge (Figure 2.5)). The clams were brought into the aquatics facility in the 331 Building and placed in the same growth system used for the periphyton studies. The clams were not feed, however, the raw river water contained materials that are typically consumed by the clams and the basins developed a film of periphyton over time from organisms in the raw river water. The clams were acclimated to the laboratory conditions for at least two weeks prior to exposure.

The uranium exposures for the clams were conducted in the same manner as the exposures for the periphyton. Figure 3.6 shows the clams in the uranium exposure system. Table 3.3 summarizes the environmental conditions for the periphyton studies.

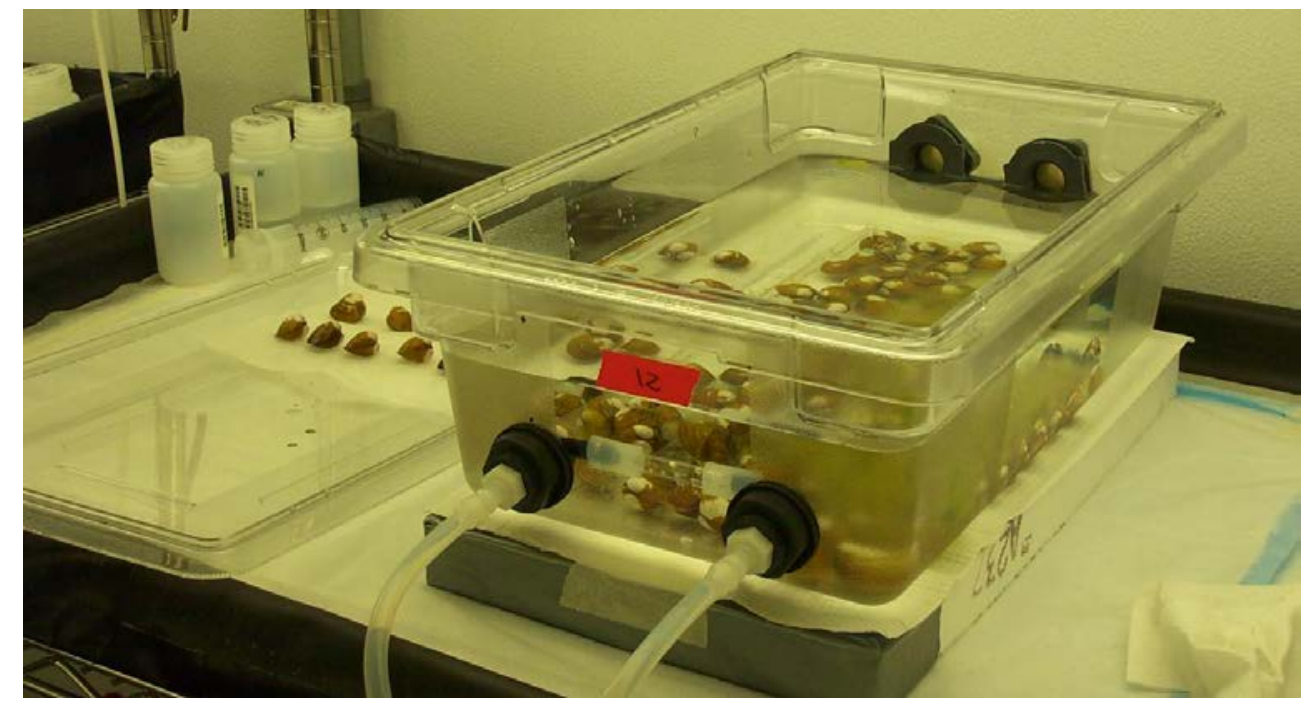

Figure 3.6. Uranium Uptake Exposure Studies With Corbicula 
Table 3.3. Environmental Conditions for the Asian clam Laboratory Studies

\begin{tabular}{||l|c||}
\hline \hline Environmental Conditions & Value for Asian Clam Studies \\
\hline \hline Light/Dark period & $16 \mathrm{hr} / 8 \mathrm{hr}$ \\
\hline Air Temperature & $18 \pm 2^{\circ} \mathrm{C}$ \\
\hline Water Temperature & $18.4 \pm 0.5^{\circ} \mathrm{C}$ \\
\hline $\mathrm{pH}$ & $7.78 \pm 0.32$ \\
\hline Hardness & $56.3 \pm 12.3 \mathrm{mg} / \mathrm{L}$ as $\mathrm{CaCO}_{3}$ \\
\hline Alkalinity & $41.8 \pm 9.0 \mathrm{mg} / \mathrm{L}$ as $\mathrm{CaCO}_{3}$ \\
\hline Dissolved Oxygen & $8 \pm 2 \mathrm{mg} / \mathrm{L}$ \\
\hline
\end{tabular}

Samples of water and clams were collected for analysis at different times for the two studies. Samples were collected for the first range finding study at: 0, 48, 96, 120, 144, and $264 \mathrm{hrs}$. Samples were collected for the first range finding study at: $0,1.5,6,24,48,96,102,120,216$, and $360 \mathrm{hrs}$. Water samples were collected and analyzed in the same manner as for the periphyton studies. The method detection limit (MDL) was $0.02 \mu \mathrm{g} / \mathrm{L}$ with analytical accuracy $>98 \%$ and precision $<1 \%$ relative percent difference (RPD).

Triplicate clam samples were collected for uranium analyses at each sampling time. Each replicate sample consisted of the soft tissue from 5 clams. Stainless steel forceps were used to remove the soft tissue from the shells. Samples were freeze-dried and homogenized using a ball-mill prior to digestion (Battelle SOP MSL-C-003). Tissue samples were digested (Battelle SOP MSL-I-024). Approximately 500-mg aliquot of each dried, homogeneous sample was combined with nitric and hydrochloric acids (aqua regia) in a Teflon vessel and heated in an oven at $130^{\circ} \mathrm{C}\left( \pm 10^{\circ} \mathrm{C}\right)$ for a minimum of eight hours. After heating and cooling, deionized water was added to the acid-digested tissue to achieve analysis volume and the digestates were submitted for analysis. Digested samples were analyzed for total U using ICP-MS (Battelle SOP MSL-I-022). All results are reported in units of $\mu \mathrm{g} / \mathrm{g}$ dry weight. The MDL was $0.0002 \mu \mathrm{g} / \mathrm{g}$ dry weight. The initial and final concentrations of uranium in the water for these tests are in Table 3.4.

Table 3.4. Exposure Concentrations in the Water Phase for Uranium Uptake by Clams

\begin{tabular}{|c|c|}
\hline \hline Initial Concentration of Uranium in Water $(\mu \mathrm{g} / \mathrm{L})$ & Final Concentration of Uranium in Water $(\mu \mathrm{g} / \mathrm{L})$ \\
\hline \hline 1.45 & 2.00 \\
\hline 4.71 & 4.21 \\
\hline 11.70 & 8.62 \\
\hline 14.10 & 9.39 \\
\hline 14.40 & 12.20 \\
\hline 82.60 & 70.50 \\
\hline 109.00 & 91.10 \\
\hline 114.00 & 67.20 \\
\hline
\end{tabular}

\subsubsection{Results for Uptake and Depuration Studies with Asian Clams}

Uranium was readily sorbed to the Asian clam's soft tissue. The range finding study indicated that an apparent equilibrium between the uranium in the water and in the soft tissue was reached within 96 to $144 \mathrm{hrs}$. The uptake period for the second study was $120 \mathrm{hrs}$. When the clams were moved from the water with the uranium to un-amended river water for the depuration period, the uranium decreased in the 
soft tissue, but at a slower rate than the uptake of uranium in the tissue. The depuration phase for the clams was longer than that for the periphyton studies: 120 hrs for the range finding study; and 240 hrs for the second study.

Figure 3.7 shows the results of the water and clam soft tissue concentrations for both studies. The figure is divided among the concentration ranges that were tested. The upper portion of the figure (A) is for the uranium exposures where the initial concentration was 82.60 to $114.00 \mu \mathrm{g} / \mathrm{L}$ uranium. The lower portion of the figure (B) is for the uranium exposures where the initial concentration was 11.70 to $14.40 \mu \mathrm{g} / \mathrm{L}$ uranium. The control concentrations (1.45 and $4.71 \mu \mathrm{g} / \mathrm{L}$ uranium) did not change significantly throughout the exposure time and are not shown in order to simplify the figure.
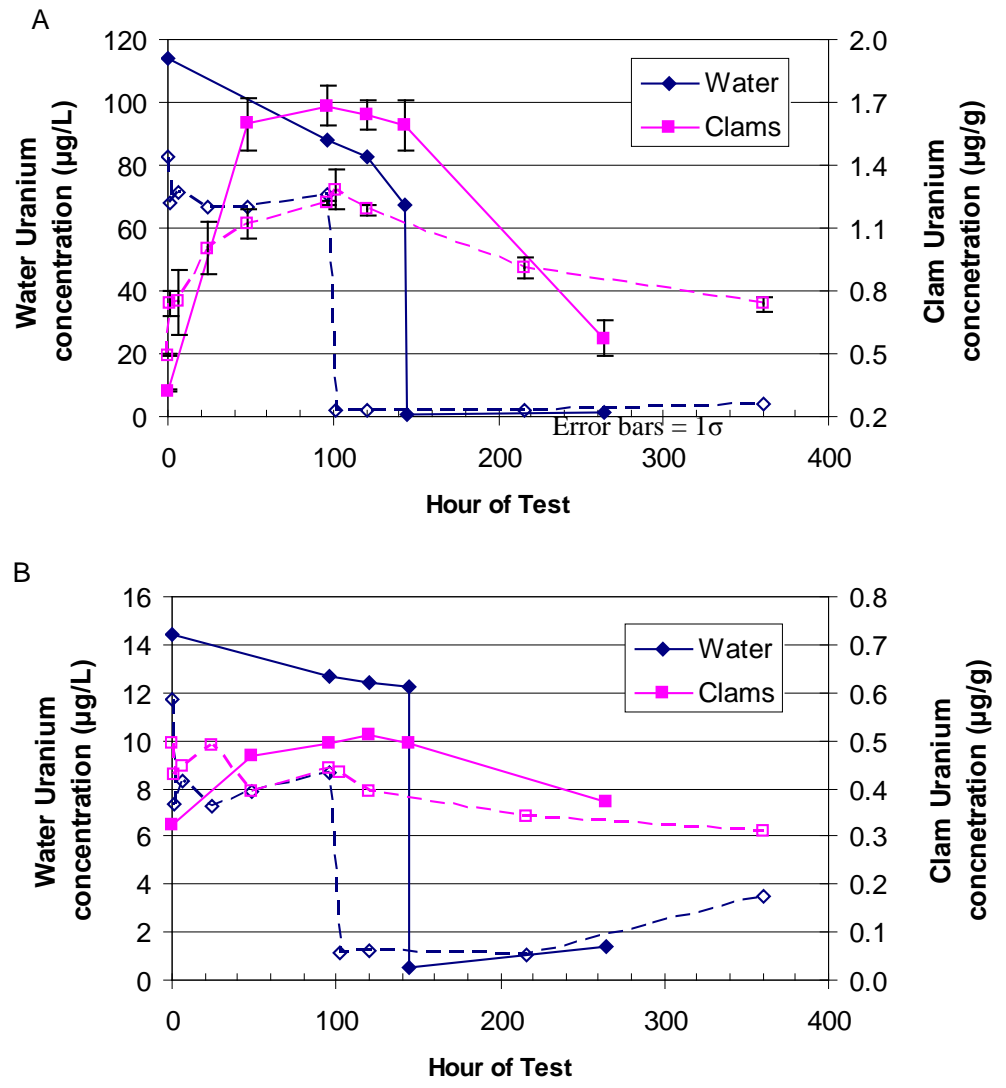

Figure 3.7. Concentrations of Uranium in Water and Clam Soft Tissue in the Uptake and Depuration Studies

As discussed in Fritz et al. 2007, the ramifications of these initial uptake studies are significant. These studies indicate that contaminants in clam soft tissue only provide an indication of short-term exposure, not long-term exposure. Making assumptions about the long-term average uranium concentration of water to which a clam has been exposed based on the uranium concentration in soft tissue would appear to be a very poor assumption at this point. The third study conducted was designed to investigate how the soft tissue of the clams responds to pulsed-exposures of uranium in comparison to the continuous exposures used in the first two studies. 


\subsubsection{Pulsed-Exposure Studies with Asian Clams}

Pulsed exposures of uranium were conducted to evaluate uptake and depuration rates using Asian clams. Flow of groundwater contaminants into surface waters can vary daily or seasonally based on such factors as river stage (Fritz et al. 2007). As a result, the exposure of contaminants to benthic organisms at the groundwater/surface water interface changes regularly. The continual change in contaminant concentration is not typically studied in laboratory exposure studies. The term "pulsed-exposure” is used to refer to the kind of changes in uranium observed at the groundwater/surface water interface. This experiment was designed to look at short-term, repeated exposures, as well as long-term, repeated exposures to understand how the soft tissue of the clams accumulated and eliminated uranium based on the exposure history.

\subsubsection{Methods and Materials for Pulsed-Exposure Studies with Asian Clams}

The collection and care of clams, laboratory exposure systems, and uranium analytical procedures used during the pulsed-exposure studies were the same as those used during the uptake and depuration studies described in Section 3.2.1. To simulate the pulsed-exposure of uranium to clams, the clams were moved from exposure systems with water at $\sim 100 \mu \mathrm{g} / \mathrm{L}$ uranium to exposure systems with un-amended river water. The clams used in the short-term and long-term pulsed-exposure studies were maintained in separate exposure systems in the laboratory.

The short-term pulsed-exposures consisted of three cycles. Each cycle consisted of 24 hrs in water amended to $\sim 100 \mu \mathrm{g} / \mathrm{L}$ uranium, followed by $24 \mathrm{hrs}$ in water un-amended with uranium. Exposure of 24 hrs was used to allow the clams to complete one complete photo period (16 hrs light : 8 hrs dark), and minimize variability associated with the clam's behavior and light exposure. Three cycles were chosen because the total exposure time for the three cycles, $120 \mathrm{hrs}$, corresponded with the continuous uptake phase used in the second clam study. After three cycles of uranium exposure, the remaining clams were allowed to depurate in un-amended water for 240 hrs.

The long-term pulsed-exposure studies consisted of two cycles. Each cycle consisted of 120 hrs in water amended to $\sim 100 \mu \mathrm{g} / \mathrm{L}$ uranium, followed by $240 \mathrm{hrs}$ in water un-amended with uranium. The exposure period for each cycle was based on the uptake and depuration phases used in the second clam study. The first cycle's uptake phase corresponded with the completion of the three short-term pulsedexposures.

Clams were observed siphoning, pedal-feeding and moving around the exposure system throughout the exposure. They would open their shells within minutes of each transfer into a new exposure system. This indicates that the clams were not inhibited by the presence of uranium in these experiments.

\subsubsection{Results for Pulsed-Exposure Studies with Asian Clams}

The results of the short-term pulsed-exposures of uranium in water with Asian clams are shown in Figure 3.8. The results of the long-term pulsed-exposures of uranium in water with Asian clams are shown in Figure 3.9. The concentration of uranium in the soft-tissue from both the short- and long-term pulsed-exposures is shown in Figure 3.10. 


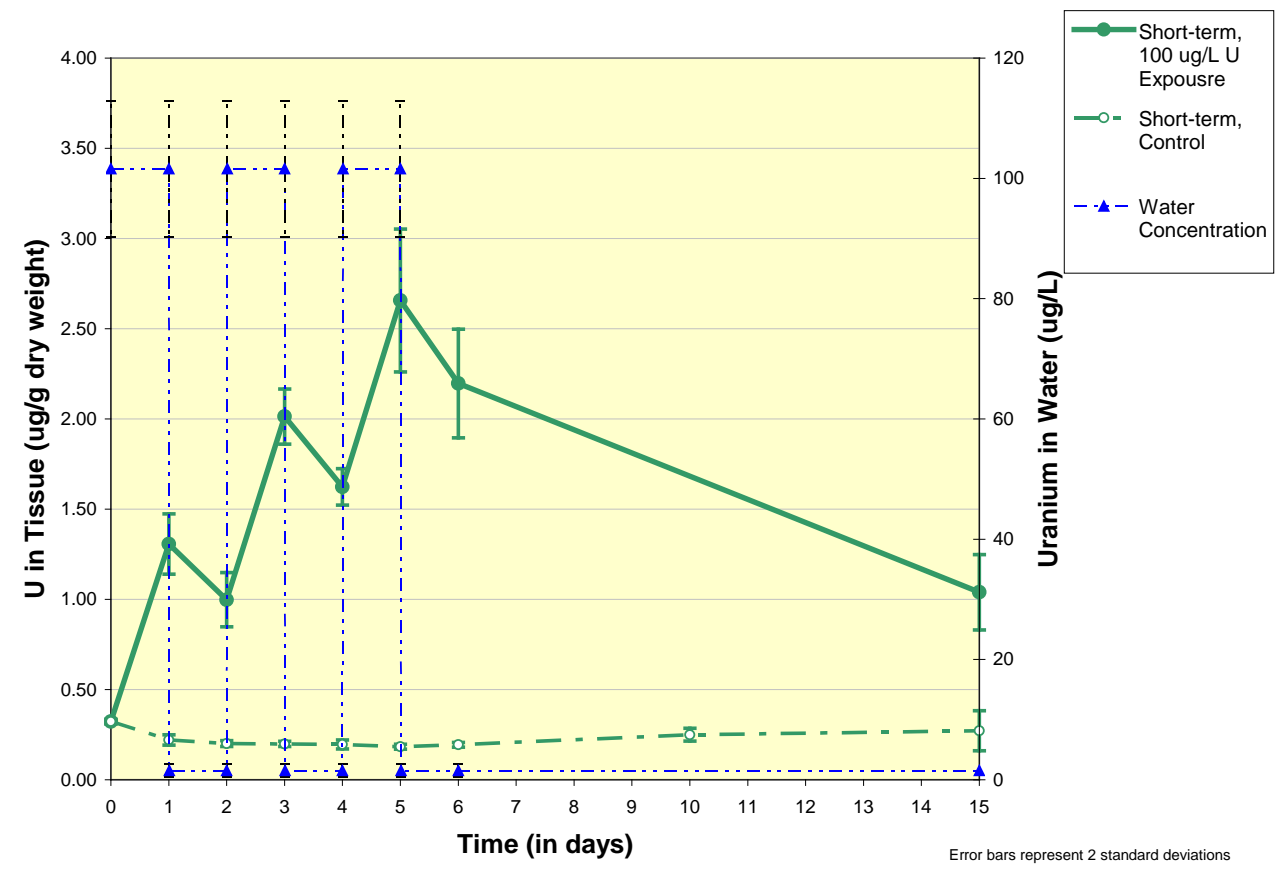

Figure 3.8. Concentration of Uranium in Water and Soft Tissue of Clams in the Short-Term PulsedExposures With Asian Clams

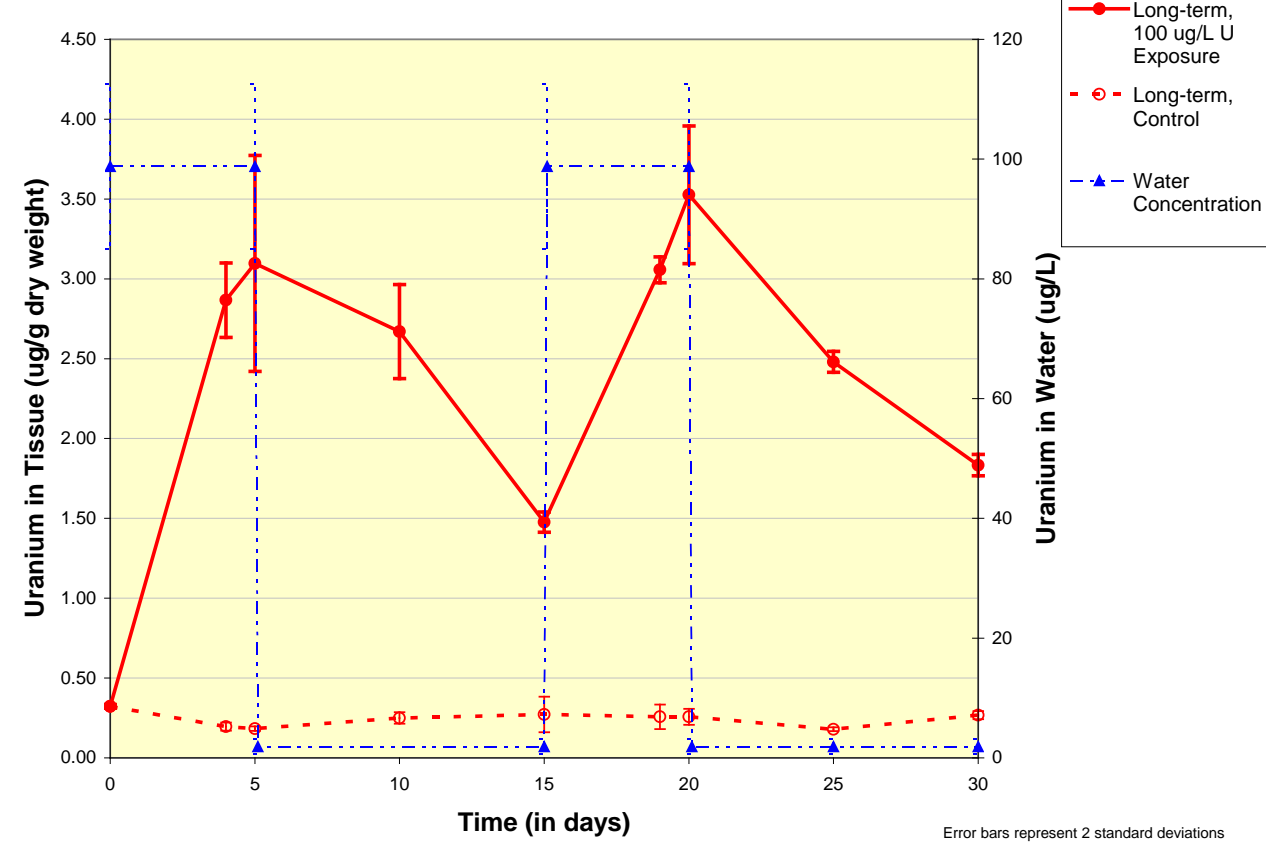

Figure 3.9. Concentration of Uranium in Water and Soft Tissue of Clams in the Long-Term PulsedExposures With Asian Clams 


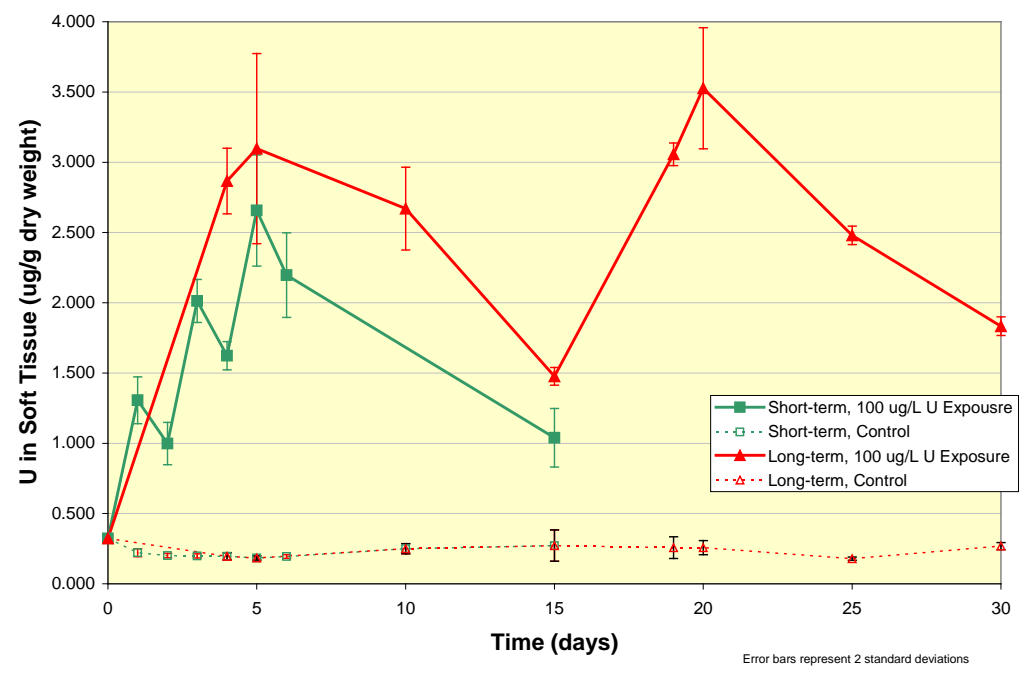

Figure 3.10. Concentration of Uranium in Soft Tissue of Clams for Both the Short- and Long-Term Pulsed-Exposures With Asian Clams

During the short-term pulsed-exposure study, there was a significant difference in the uranium concentration in the soft tissue for each cycle. This is illustrated in Figure 3.8 where the error bars (two standard deviations) do not overlap each other at with each cycle's uptake and depuration phases. At the end of the last depuration phase, the uranium concentration in the soft tissue is still higher than the initial uranium concentration at the beginning of the study and higher than the control clams throughout the study.

During the long-term pulsed exposure study, there was no significant difference in the uranium concentration in the soft tissue for each uptake phase. This is illustrated in Figure 3.9where the error bars (two standard deviations) overlap each other at 5 and 20 days. At the end of the each depuration phase, the uranium concentration in the soft tissue is higher than the initial uranium concentration at the beginning of the study and higher than the control clams throughout the study. After the second cycle and at the end of the depuration phase (30 days), the uranium in the soft tissue is significantly greater than the concentration in the soft tissue at the end of the first cycle (15 days).

The response of Asian clams to their exposure history in uranium-amended and un-amended water is illustrated in Figure 3.10. At day 5, the uranium concentration in the clams after three cycles of exposure during the short-term pulsed-exposure study is not significantly different from the uranium concentration in the clams after one cycle of exposure during the long-term pulsed-exposure study. However, the depuration rates were different between the short- and long-term pulsed-exposures based on the loss of uranium seen in the tissues from days 5 to 15 . The final uranium concentration in the clams at the end of the short-term study (day 15) is significantly lower than the uranium concentration in the clams at the end of each cycle's depuration phase for the long-term study.

The results from this study suggest have some implications on the use of Asian clams as a bioindicator of uranium contamination in the near-shore environment. All exposure studies summarized in this report indicate that clam soft tissue accumulates uranium from a water exposure. The pulsedexposure study shows that the concentration in the tissues can increase or decrease quickly in response to a change in water concentration. 


\subsection{Calculation of BCFs from Laboratory Studies}

Biological concentration factor (BCF) is an important parameter in the calculation of the uranium body burden in an organism, as discussed further in Section 4. BCF is a ratio of the concentration of a contaminant in the organism to the concentration of the contaminant in water. Values for the BCF for uranium in periphyton and clams (as well as for the organisms consumed by the clams) have been collected from literature and used in ecological risk models for risk assessments of areas at the Hanford Site. The values in the literature for uranium and these organisms range over several orders of magnitude and were collected from environments or laboratories with water that may or may not be similar to the Columbia River's water.

For this report, BCFs were calculated from the laboratory exposure studies of periphyton and clams. The BCFs are based on the tissue concentration and the water concentration at the exposure times when steady-state equilibrium conditions were apparent. For periphyton, equilibrium between the concentration of uranium in the biomass and the water was apparent after 48 hrs of exposure (Figure 3.3). Figure 3.11 shows the BCFs for periphyton and uranium that were calculated for the samples collected at 48, 72 and 120 hrs. For clams, equilibrium between the concentration of uranium in the soft tissue and water was apparent after 96 hrs of exposure (Figure 3.6). Figure 3.12 shows the BCFs for periphyton and uranium that were calculated for the samples collected at 96, 120 and 144 hrs.

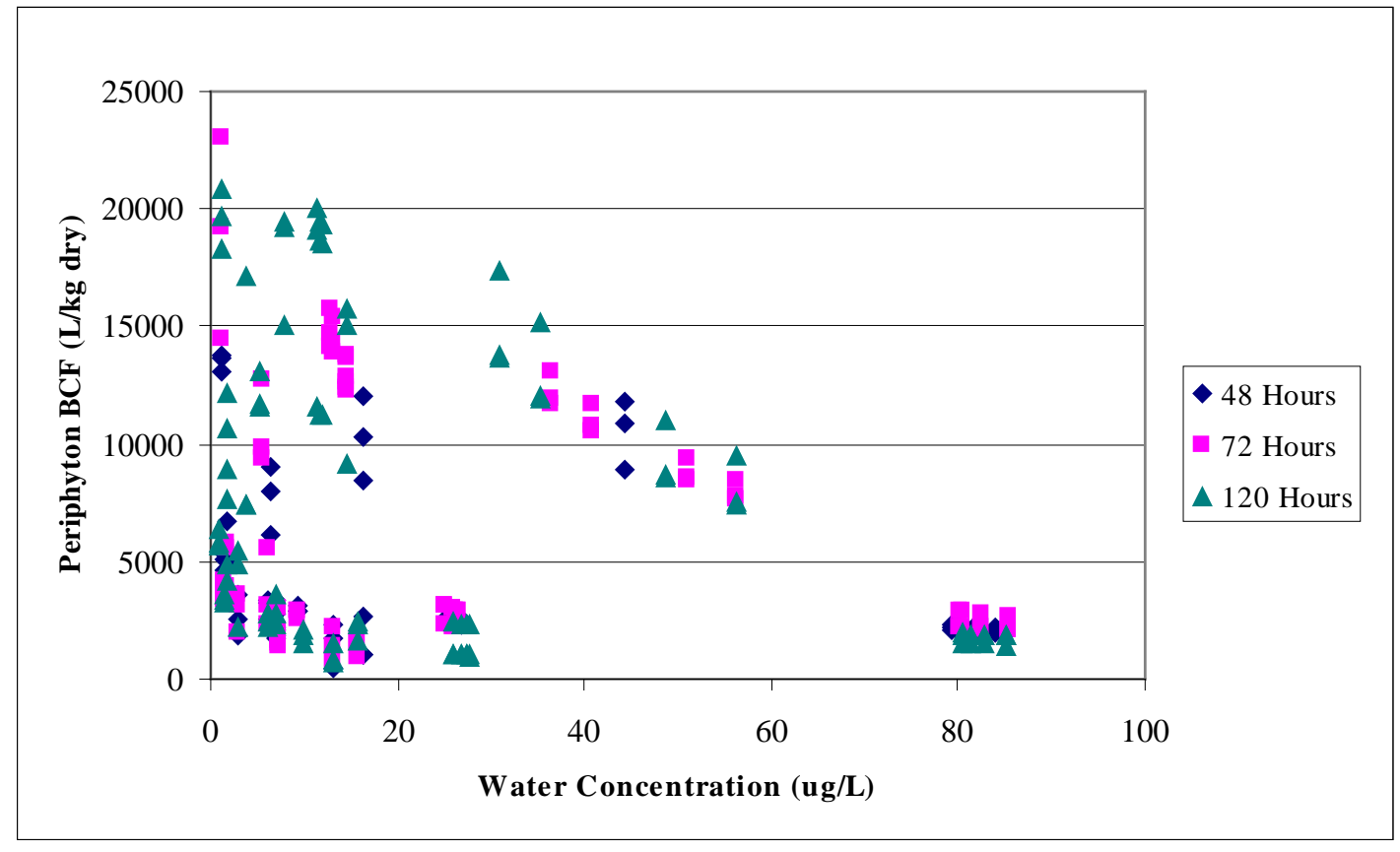

Figure 3.11. Periphyton BCF vs. Water Concentration Based on Laboratory Exposure Studies 


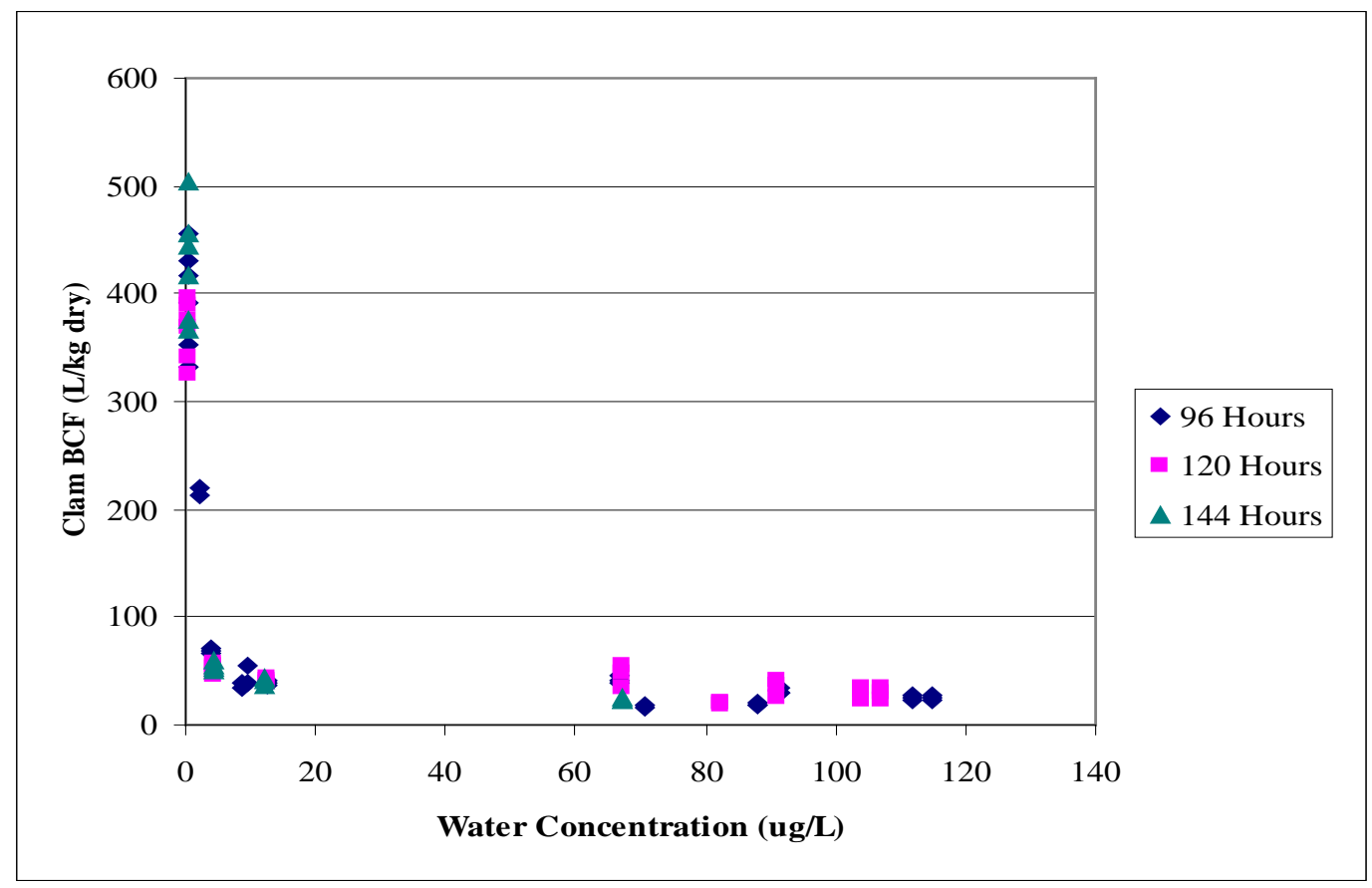

Figure 3.12. Corbicula BCF vs. Water Concentration Based on Laboratory Exposure Studies

Periphyton and clams accumulate uranium differently. Figure 3.11 and Figure 3.12 show that the BCFs for periphyton and clams is not dependent on time once an apparent equilibrium between the tissues and water concentrations is reached. The BCF for periphyton is generally higher than the BCF for clams (Figure 3.11). While there is a downward trend in BCF with higher water concentrations, the most predominant pattern is that the BCF ranges over three orders of magnitude (Figure 3.11). The BCF for clams is clearly a function of water concentration. 



\subsection{Field Monitoring Data for Uranium in the Aquatic Environment}

Environmental and biological monitoring along the Hanford Reach of the Columbia River has been on-going since 1945 (Becker 1990). Environmental data to support the evaluation of modeled and laboratory- uptake of uranium in benthic aquatic organisms were assembled from existing monitoring data. This section includes a discussion of uranium in surface water, pore water and sediment collected from the 300 Area at the Hanford Site for the comparison of the measured field values to the modeled values. Detailed data tables and plots of media concentrations over time can be found in Appendix A.

\subsection{Abiotic Media Data}

The key abiotic media for benthic aquatic organisms are pore water, surface water and sediment. Media concentrations were obtained from the Surface Environmental Surveillance Project (SESP). SESP is a multimedia environmental monitoring effort to measure the concentration of radionuclides and chemicals in environmental media and assess the integrated effects of these materials on the environment and the public. Project personnel collect samples of air, surface water, sediments, soil and natural vegetation, agricultural products, fish, and wildlife. Samples are analyzed for very low environmental concentrations of radionuclides and nonradiological chemicals including metals, anions, and volatile organic compounds (DOE 2000). The project focuses on routine releases from DOE facilities on the Hanford Site; however, the project is also responsive to unplanned releases and releases from non-DOE operations on and near the site. Surveillance results are provided annually through the Hanford Site Environmental Report (e.g., Poston et al. 2007).

\subsection{Calculation of Exposure Point Concentrations}

The exposure concentrations for the various environmental media were calculated using the abiotic media data described above. These calculations relied upon a number of assumptions regarding interconverting chemical concentrations and isotopic concentrations for uranium, the appropriateness of near-shore aquifer tube and drive point data for use as pore water, and surrogation to fill in for missing media data.

While the interim cleanup standard for uranium is based on chemical uranium, it is important in a risk assessment to consider the carcinogenic effects of uranium isotopes, e.g., uranium-234, -235, and -238. Health effects are a function of concentration and radioactivity. Uranium isotopes have very long halflives: 244,000 years for uranium-234; 710 million years for uranium-235; and 4.5 billion years for uranium 238. More radiation is released per unit time from a given quantity of the shorter half-life isotope compared to the longer half-life isotope. That is, for one gram of each isotope side by side, the uranium-234 will be about 20,000 times more radioactive, and the uranium-235 will be 6 times more radioactive, than the uranium-238 (ATSDR 1999). The natural abundance of uranium isotopes is $99.27 \%$ uranium-238, 0.72\% uranium-235, and 0.0055\% uranium-234 (Lide 2000). One gram of natural uranium having this relative isotopic abundance has an activity of $0.67 \mu \mathrm{Ci}$. From this activity of natural uranium, $48.9 \%$ of the activity is attributable to uranium-234, $2.2 \%$ of the activity is attributable to uranium-235, and $48.9 \%$ of the activity is attributable to uranium-238. Although the relative mass abundance of uranium-234 is only $0.0055 \%$, this accounts for exactly one-half of the total activity (ATSDR 1999). Thus, all the isotopes of uranium are important to consider in a health assessment, especially for long lived aquatic organisms like some species of mussels. 
Some of the media in the 300 Area did not have measured data for both chemical and isotopic uranium. Where isotopic uranium values were not provided, specific activity and natural abundance were used to estimate isotopic uranium values. The uranium isotopic compositions in groundwater samples taken south of the 300 Area were not significantly different from natural ratios (Dresel et al. 2002). Patton et al. (2003) showed that the uranium isotopic ratios in the 300 Area seeps were similar for all locations and did not reveal isotopic enrichment from fuel production processes in the 300 Area.

Pore water, the interstitial water in the riverbed sediments, is the critical medium for impacts to aquatic organisms. Through food chain impacts, pore water exposure is also important to terrestrial animals and humans. While it is well known that there is a zone of groundwater/river water interaction, the relative proportion of groundwater to surface water at any point within the ZOI is not well known and has been shown to vary with time. Rather than use a ratio of the groundwater and surface water to estimate the pore water concentration, direct measurements made through aquifer tubes and drive point samples were used (Figure 2.4).

The depth to which river water becomes entrained in riverbed sediment can vary widely, along with the degree of contaminant dilution that might occur when river water mixes with upwelling groundwater. Frtiz et al. 2007 discusses the variation of uranium in the near-shore hyporheic environment of the 300 Area through intensive sampling in river tubes, aquifer tubes, and near-shore groundwater, as well as in hydraulic conductivity testing. Because no new field data were collected for this study, surrogate data for groundwater in riverbed habitat were used. The surrogate data were maximum values for observations from aquifer tubes located along the shoreline, which typically provide samples from the aquifer at depths below ground surface ranging from 2 to $8 \mathrm{~m}$, and from drive points positioned offshore in the riverbed, with sample port at depths less than $2 \mathrm{~m}$ below the riverbed surface.

Table 4.1 summarizes the abiotic media data for this report. In essentially all instances, the maximum value for a contaminant of interest would come from an aquifer tube sample, since those samples rarely show dilution by river water except for occasional dilution at the shallowest of the tube completions. The data plots in Appendix A show that the aquifer tube and drive point data appear to represent nearly the same subsurface conditions, with some evidence for dilution of contaminant concentrations in the drive point data. Consequently, the data from the two types of sampling sites were combined to develop the pore water dataset that will be used in Section 6.

\subsection{Biotic Media Data}

Asian clams are the most common benthic aquatic organism collected for biological monitoring along the Hanford Reach. In the past few years, several monitoring programs for the Hanford Site have been using this organism as a sentinel species for finding regions where contaminated groundwater is entering the Columbia River. Uranium analyses of the soft tissue from Asian clams collected in the Hanford Reach of the Columbia River are shown in Figure 4.1 and are discussed further in Appendix A. This data could be used for calculation of a BCF if a water sample was taken concurrent with the collection of the clams and that water sample represents the concentration of uranium that the clams were exposed to for at least the last 48 hrs prior to collection. The assumptions for calculation of a BCF using field measured values are discussed further in Section 6. 
Table 4.1. Summary of Abiotic Media Data for Uranium in Pore Water, Surface Water and Sediment

\begin{tabular}{|c|c|c|c|c|c|c|}
\hline Contaminant & \multicolumn{3}{|c|}{ Pore Water Concentrations } & \multicolumn{3}{|c|}{ Surface Water Concentrations } \\
\hline $\begin{array}{l}\text { Nonradionuclides } \\
(\mu \mathrm{g} / \mathrm{L})\end{array}$ & $\begin{array}{l}\text { Geometric } \\
\text { Mean }\end{array}$ & $\begin{array}{c}\text { Geometric } \\
\text { Standard } \\
\text { Deviation }\end{array}$ & Best Estimate & $\begin{array}{c}\text { Geometric } \\
\text { Mean }\end{array}$ & $\begin{array}{c}\text { Geometric } \\
\text { Standard } \\
\text { Deviation }\end{array}$ & Best Estimate \\
\hline Uranium & 81.3 & 2.48 & 81.3 & 1.01 & 3.40 & 1.01 \\
\hline $\begin{array}{l}\text { Radionuclides } \\
\text { (pCi/L) }\end{array}$ & & & & & & \\
\hline Uranium-234 & 28.0 & 2.55 & 28.0 & 0.37 & 2.38 & 0.37 \\
\hline Uranium-235 & 1.16 & 2.50 & 1.16 & 0.011 & 4.22 & 0.011 \\
\hline Uranium-238 & 24.5 & 2.37 & 24.5 & 0.31 & 2.52 & 0.31 \\
\hline Contaminant & \multicolumn{3}{|c|}{ Sediment Concentrations } & & & \\
\hline $\begin{array}{l}\text { Non- } \\
\text { Radionuclides } \\
(\mu \mathrm{g} / \mathrm{g})\end{array}$ & $\begin{array}{l}\text { Geometric } \\
\text { Mean }\end{array}$ & $\begin{array}{l}\text { Geometric } \\
\text { Standard } \\
\text { Deviation }\end{array}$ & Best Estimate & & & \\
\hline Uranium & 4.77 & 3.16 & 4.77 & & & \\
\hline $\begin{array}{l}\text { Radionuclides } \\
\text { (pCi/g) }\end{array}$ & & & & & & \\
\hline Uranium-234 & 1.45 & 3.16 & 1.45 & & & \\
\hline Uranium-235 & 0.071 & 3.04 & 0.071 & & & \\
\hline Uranium-238 & 1.59 & 2.86 & 1.59 & & & \\
\hline
\end{tabular}

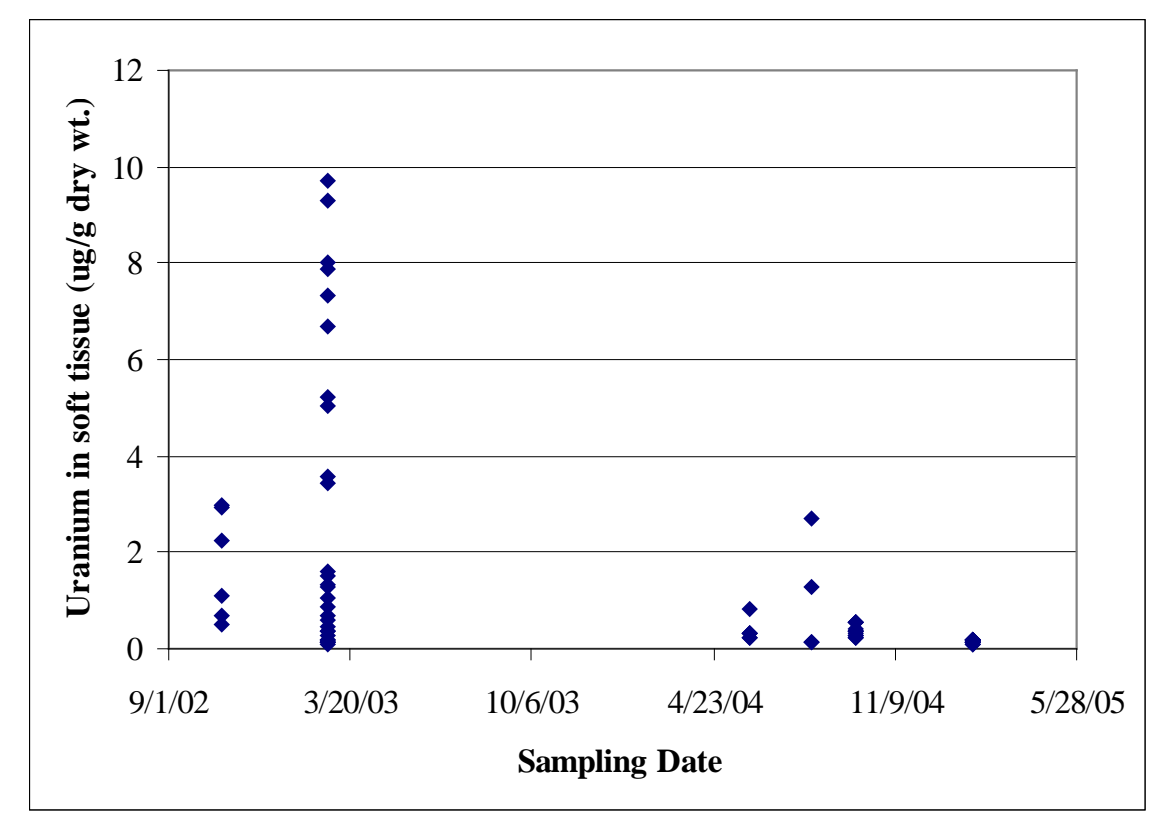

Figure 4.1. Uranium Concentration in Soft Tissues From Corbicula Collected in the Hanford Reach of the Columbia River.

Periphyton is not commonly collected for biological monitoring along the Hanford Reach. However, the community is a critical food source for numerous aquatic organisms. There have been more recent programs looking at periphyton and uranium uptake in the river, but the data was not available for this report. 



\subsection{Ecological Contaminant Exposure Model}

This section describes the mathematical basis for ecological risk modeling, an overview of the Ecological Contaminant Exposure Model (ECEM), and the parameters that have been used for assessing risk to aquatic organisms at Hanford using ECEM and literature values. The information in this section will be applied to the model runs in Section 6.

\subsection{Background for Ecological Risk Assessment Modeling}

Exposure estimation modeling is a central component of risk assessments. Examining effects of pastpractice discharges to the environment, estimating the consequences of accidental releases of hazardous materials, and determining if and how chemicals may be used in an environmental setting (for pesticide registration, for example) are the kinds of assessments that can be conducted with exposure estimation modeling. Ecological exposure models exhibit an array of complexity, ranging from relatively simplistic single-species, single-chemical, single-environmental-compartment models (such as in EPA 1999) to more sophisticated multi-species, multi chemical. multi-compartment models (such as in Gobas et al. 1998, Freeman et al. 2004, and Zakikhani et al. 2006). Regulators and stakeholders occasionally require complex models to accommodate ecological or environmental conditions that are thought to be inadequately represented by simple or generalized models.

A number of existing ecological exposure models are able to accommodate one or more aspects of complex ecosystems and exposure pathways. The Wildlife Contaminants Exposure Model, which was developed by the Canadian Wildlife Service through a cooperative agreement with the National Center for Environmental Assessment of the U.S. Environmental Protection Agency's Office of Research and Development, estimates wildlife exposure to organic and inorganic contaminants through inhalation and ingestion of food, water and soil (MESO 2004). The model addresses 24 species of birds, 17 mammals, 5 reptiles, and 3 amphibians from North American environments (Freeman et al. 2004).

The Terrestrial Wildlife Exposure Model, which is a component of the U.S. Army Corps of Engineers' Army Risk Assessment Modeling System (ARAMS), addresses ingestion of food, soil, and surface water for 26 species of birds, 21 mammals, and 8 reptiles representing North American fauna (CH2M HILL 2001). Limitations of this model include its taxonomic coverage, limited exposure pathways, and lack of mechanistic components to address aquatic ecosystems (Zakikhani et al. 2006). Aquatic species in ARAMS are addressed by a combination of databases (Environmental Residue Effects Database, biota/sediment accumulation factor database) and single-compartment models (such as the Theoretical Bioaccumulation Potential Model) that estimate tissue concentrations using measured sediment concentrations and the biota/sediment accumulation factor database (Zakikhani et al. 2006). However, ARAMS does include a component module that accommodates species with home ranges that encompass spatially varying environmental concentrations of contaminants (the Spatially Explicit Exposure Model (Von Stackelberg et al, 2005). 
A number of models address biological accumulation in aquatic food webs, including AQUAWEB (Arnot and Gobas 2004), the EcoFate Model (Thomann 1998), and other unnamed models (Thomann 1989; Thomann et al. 1992; Thomann et al. 1995). AQUAWEB and EcoFate are limited to organic chemicals, as is the Thomann 1989 and Thomann et al. 1992 models, while the Thomann et al. 1995 model addresses only metals in sediment. These models address exposure of aquatic species through ingestion and gill uptake pathways from water and/or sediment compartments, and include at least two components of a larger food web.

A number of ecological exposure and bioaccumulation models have been developed to address radionuclide transport in the environment. Most of these models have the human food supply as their primary output, including milk, meat, and eggs (for example, GENII (Napier 2002) and ERMYN (Wu 2003)). Most rely upon transfer factors or coefficients to convert abiotic media concentrations into specific tissue concentrations for common species of interest, such as cattle, sheep, and pigs (e.g., $\mathrm{Ng}$ et al. 1982), although coefficients for less common wild foods such as seals and walrus have been developed to support specific components of society (e.g., Layton et al. 1997). These models primarily address exposure and accumulation within a single receptor from radionuclides where the model uses only one or two environmental compartments, e.g., RESRAD (Yu et al. 2002). The GENII code provides a more complete analytical framework, including problematic radionuclides such as tritium and ${ }^{14} \mathrm{C}$ occurring in multiple abiotic compartments and a limited food chain capability.

A single, multimedia modeling system capable of addressing metals and radionuclide contaminants in both aquatic and terrestrial systems is lacking. This produces a potentially significant stumbling block to analyses of complex environmental systems at the Hanford Site where many classes of contaminants have been introduced to the environment since nuclear operations began on the site in 1943.

Because the history of contamination at the Hanford Site is one of past-practice disposal, the nature of biological exposures is chronic rather than acute. This is borne out by the long-term monitoring programs that look at environmental and biological concentration of key contaminants (Poston et al. 2007; Hartmann et al. 2007). Therefore, the assessment approach uses equilibrium models where exposure effects are estimated using the assumption that each organism spends enough time in a given location that the concentration of contaminants in the organism's tissue is in equilibrium with the environment; there is no net gain or loss of contaminant from the organism. As a system of equations, an associated implicit assumption is that that the entire food web continues to function, even in the presence of potentially deadly levels of contaminants.

The discussion of the mathematical basis for modeling contaminant uptake in aquatic environments can be found in Appendix B. The portion of the aquatic environment discussed in the appendix is focused on the primary producers (periphyton, plankton, plants), herbivores, and carnivores or omnivores (consumers of both flesh and plant material) as generalized in Figure 2.3. Contaminants to be modeled include metals and radioactive elements. Solutions produced include body burdens for all contaminants and radioactive dose from internal and external pathways for radioactive contaminants. For aquatic species and metals, estimates of tissue concentration can be compared to toxicological benchmarks to obtain a chemical hazard quotient. 


\subsection{Structure of the Ecological Contaminant Exposure Model}

The Ecological Contaminant Exposure Model (ECEM) is a multimedia, food chain-based chronic exposure model. It is intended for use in situations where chemicals of concern are temporally invariant or are sufficiently static such that exposed organisms reach equilibrium with the environment. Contaminant concentration may vary spatially, however, on any scale.

The ECEM code accommodates radioactive, inorganic, and organic contaminants. Multimedia exposure results are provided as tissue concentrations or dose for chemicals and radionuclides; health risks are quantified by converting these exposure metrics into hazard quotients, which are the dimensionless ratio of the estimated exposure to a toxicological reference benchmark. ECEM implements a series of ecological risk models that have been developed for applications in only terrestrial or aquatic systems, or only for plants or animals, to assess the entire range of organisms present at the Hanford Site.

Ecological risk is based on a comparison of the concentration in the species to a standard that is known to be a measure of risk, such as a regulatory standard like EPS's Ambient Water Quality Criteria. The contaminant concentration in the species is the total body burden, which is a sum of the accumulation of the contaminant from all pathways. In a laboratory or field study, the concentration in an organism's tissues is the total body burden. Whereas, in ecological risk models, the total body burden is a calculation based on what is known about the contaminant concentration in the environment (e.g., water and sediment) and what is known about how an organism accumulates the contaminant from all the pathways of exposure.

The pathways of exposure that can lead to accumulation and the process for determining the total body burden in aquatic species is represented in Figure 5.1. These include accumulation of the contaminant from the water and food. The body burdens of aquatic animals and plants are based on mass-balance equilibrium models that estimate exposures of aquatic organisms to the contaminants in sediments, pore water, surface water, and the subsequent transfer through the food chain (Thomann 1989; Thomann et al. 1992, 1995; Baker and Soldat 1992; EPA 1993b). More specifically, direct exposure of a contaminant like uranium through water can result in accumulation of the contaminant in the tissues. However, direct exposure to uranium bound in sediment results in insignificant accumulation in the tissues. Uranium bound to sediment is a more significant contributor to the total body burden through the food pathway. A species is also able to change the contaminant concentration in its tissues, known as regulation. If a contaminant is actually an essential nutrient, the organism can actively uptake the chemical from the environment (e.g., with calcium). In contrast, if the contaminant can cause harm, the organism can actively eliminate the chemical from its tissues (e.g., with mercury). The ability of the organism to regulate contaminants is represented in Figure 5.1 (and in ECEM) by the biological concentration factor (BCF), assimilation, depuration and growth in the organism as well as in the prey of that organism. Terms in the figure, such as BCF, are further defined in the next section of this report.

While Figure 5.1 implies that single values are used, ECEM is actually a stochastic code, accommodating uncertainty in environmental conditions and biological transport. The code accepts definition of parameters according to best-estimate, maximum, and minimum values, and type of distribution (uniform, triangular, normal, or lognormal). For this report, only the input contaminant concentrations were modeled stochastically. All of the uncertainty in the ecological results is due to variability in the input concentrations and not to variability in the ECEM parameters. 


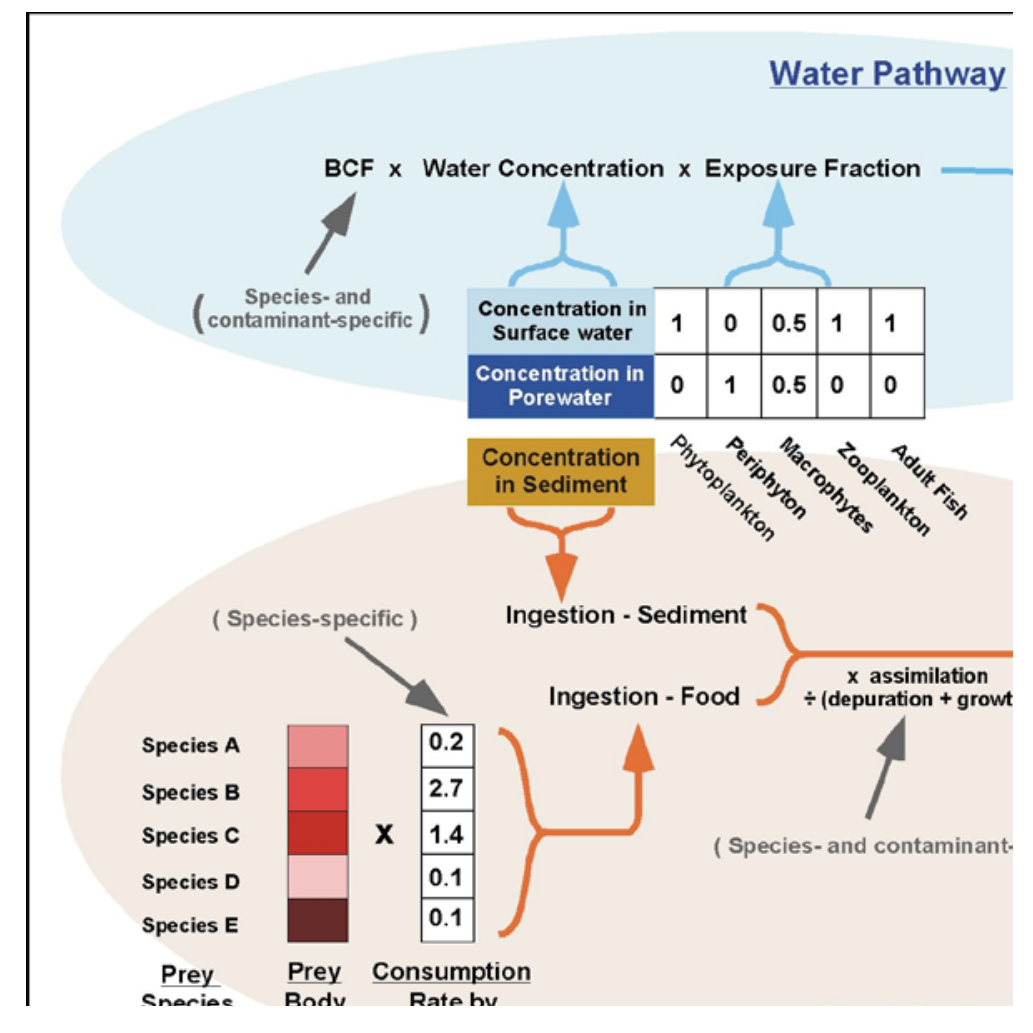

Figure 5.1. Representation of the Accumulation of Contaminants and the Process for Determining the Total Body Burden in Aquatic Species Using ECEM.

\subsection{Parameterization of ECEM}

The following section describes the parameters used in ECEM for this report. The equations for the ECEM code are documented in Volume 2 of the updated User Instructions for the System Assessment Capability, Rev. 1, Computer Codes (Eslinger et al. 2006). The equations used in this report are discussed further in Appendix B. The ECEM code has been used in previous risk assessments for the Columbia River Comprehensive Impact Assessment: Screening Assessment and Requirements for a Complete Assessment (DOE 1998a) and Hanford site-wide assessments (Bryce et al. 2002), 100-NR-2 Groundwater Operable Unit (DOE 2006a), 200-ZP-1 Groundwater Operable Unit (DOE 2006b), and 300-FF-5 Groundwater Operable Unit (Miley et al. 2007).

Table 5.1 lists the parameters used in modeling the simplified benthic aquatic food chain for this report. Further discussion of these parameters can be found in Eslinger et al. 2002 and 2006. Table 5.2 lists the non-stochastic values, and Table 5.3 lists the stochastic values. The basis and references for the values in Table 5.2 and Table 5.3 can be found in Miley et al. 2006 and 2007. There are some stochastic values that are only specific to the species being analyzed, and others that are species and analyte specific. One of the stochastic values is the BCF. Note that the range and distribution of the stochastic values that has been collected from the literature and used in past assessments with ECEM do not represent the range and distribution measured in the laboratory studies for periphyton and clams, as illustrated in Figure 3.11 and Figure 3.12. 
Table 5.1. Description of Parameters Associated With the ECEM Model for Assessing Uranium in the Aquatic Food Chain

\begin{tabular}{|c|c|}
\hline Parameter & $\begin{array}{ll}\text { Description } \\
\end{array}$ \\
\hline $\mathrm{AE}$ & $\begin{array}{l}\text { The assimilation efficiency of the species. Value is unitless. AE defaults } \\
\text { to zero. }\end{array}$ \\
\hline ALPHAIJ & $\begin{array}{l}\alpha_{\mathrm{ij}} \text {, the chemical assimilation efficiency for an analyte specific to a species. } \\
\text { Value has units of g contaminant assimilated per g contaminant ingested. }\end{array}$ \\
\hline AWD & $\begin{array}{l}\text { Wet-to-dry weight ratio of the species. Value has units of g wet/g dry. } \\
\text { Entry of this modifier is optional. If it is not present, the value of AWD } \\
\text { defaults to zero. }\end{array}$ \\
\hline BCF & $\begin{array}{l}\text { Biological concentration factor for metals and radionuclides. Value has } \\
\text { units of L/kg. }\end{array}$ \\
\hline BPORE & $\begin{array}{l}\mathrm{b}_{\text {pore }} \text {, the relative exposure time to pore water. This value is unitless, and } \\
\text { ranges from } 0 \text { to } 1 \text {, where } 0 \text { is for an organism that is always exposed to } \\
\text { pore water and in the sediments. }\end{array}$ \\
\hline DEPRATE & $\begin{array}{l}\mathrm{K}_{\mathrm{e} i} \text {, the depuration rate for an organism for an analyte specific to a species. } \\
\text { Units are in } 1 / \text { day. }\end{array}$ \\
\hline ENERGY & $\begin{array}{l}\varepsilon \square \text {,c), the effective absorbed energy rate for nuclide c per unit activity in } \\
\text { organism. Units are in } \mathrm{kg} \mathrm{rad} / \mathrm{pCi} / \mathrm{d} \text {. }\end{array}$ \\
\hline FABOVE & $\begin{array}{l}\mathrm{F}_{\text {above }} \text {, the fractional time for exposure of organism above the sediment. } \\
\text { This value is unitless, and ranges from } 0 \text { to } 1 \text {, where } 0 \text { is for an organism } \\
\text { that is entirely below substrate and shielded from radiological exposure. }\end{array}$ \\
\hline FLIPID & $\begin{array}{l}\text { Lipid fraction of the species. Value has units of g lipid/g wet. Entry of this } \\
\text { modifier is optional. If it is not present, the value of FLIPID defaults to } \\
\text { zero. }\end{array}$ \\
\hline FOC & $\begin{array}{l}\text { Organic carbon fraction of the species. Value has units of g organic } \\
\text { carbon/g dry weight. Entry of this modifier is optional. If it is not present, } \\
\text { the value of FOC defaults to zero. }\end{array}$ \\
\hline GE & $\begin{array}{l}\text { Gross energy for the species. Value has units of kcal/kg wet weight. Entry } \\
\text { of this modifier is optional. If it is not present, the value of GE defaults to } \\
\text { zero. }\end{array}$ \\
\hline OCAR & $\begin{array}{l}\text { Organic carbon assimilation rate for the species. Value has units of g } \\
\text { organic carbon assimilated/g ingested. Entry of this modifier is optional. If } \\
\text { it is not present, the value of OCAR defaults to zero. }\end{array}$ \\
\hline RADIUS & $\begin{array}{l}\text { Radius of the species. Value has units of cm. Entry of this modifier is } \\
\text { optional. If it is not present, the value of RADIUS defaults to zero. }\end{array}$ \\
\hline WBMASS & $\begin{array}{l}\text { Wet body mass for the species. Value has units of grams. Entry of this } \\
\text { modifier is optional. If it is not present, the value of WBMASS defaults to } \\
\text { zero. }\end{array}$ \\
\hline
\end{tabular}

Table 5.2. Values for the Non-Stochastic Parameters in the ECEM Model for Assessing Uranium in the Aquatic Food Chain

\begin{tabular}{||l|c|c|c|c|c|c|c||}
\hline \hline Species Name & AWD & FOC & OCAR & RADIUS & WBMASS & AE & GE \\
\hline \hline Clams & 3.85 & 0.399 & 0.5 & 1.4 & 5 & 0.77 & 800 \\
\hline Daphnia & 6 & 0.518 & 0.3 & 1.4 & 0.000035 & 0.77 & 740 \\
\hline Hyallela & 6 & 0.518 & 0.3 & 1.4 & 0.006 & 0.77 & 1100 \\
\hline periphyton & 10 & 0.35 & NA & 1.4 & 0.000035 & 0.23 & 510 \\
\hline phytoplankton & 10 & 0.35 & NA & 1.4 & 0.000035 & 0.23 & 510 \\
\hline \hline
\end{tabular}


Table 5.3. Values for the Stochastic Parameters the ECEM Model for Assessing Uranium in the Aquatic Food Chain

\begin{tabular}{|c|c|c|c|c|c|c|c|}
\hline $\begin{array}{l}\text { Species } \\
\text { Name }\end{array}$ & Variable & $\begin{array}{c}\text { Analyte- } \\
\text { Dependent? }\end{array}$ & Distribution & $\begin{array}{l}\text { Lower } \\
\text { Limit }\end{array}$ & Mode & $\begin{array}{l}\text { Upper } \\
\text { Limit }\end{array}$ & $\begin{array}{c}\text { Best } \\
\text { Estimate }\end{array}$ \\
\hline \multirow[t]{5}{*}{ Clams } & ALPHAIJ & $\mathrm{X}$ & Triangular & 0.0004 & 0.05 & 0.31 & 0.05 \\
\hline & BCF & $\mathrm{X}$ & Triangular & 27.9 & 31 & 34.1 & 31 \\
\hline & BPORE & & Triangular & 0.45 & 0.8 & 1 & 0.8 \\
\hline & DEPRATE & $X$ & Triangular & 0.0126 & 0.014 & 0.0154 & 0.014 \\
\hline & FABOVE & & Triangular & 0.3 & 0.5 & 0.7 & 0.5 \\
\hline \multirow[t]{5}{*}{ Daphnia } & ALPHAIJ & $\mathrm{X}$ & Triangular & 0.0004 & 0.05 & 0.31 & 0.05 \\
\hline & BCF & $X$ & Triangular & 27.9 & 31 & 34.1 & 31 \\
\hline & BPORE & & Constant & & 0 & & 0 \\
\hline & DEPRATE & $X$ & Triangular & 0.0126 & 0.014 & 0.0154 & 0.014 \\
\hline & FABOVE & & Constant & & 1 & & 1 \\
\hline \multirow[t]{5}{*}{ Hyallela } & ALPHAIJ & $\mathrm{X}$ & Triangular & 0.0004 & 0.05 & 0.31 & 0.05 \\
\hline & BCF & $\mathrm{X}$ & Triangular & 27.9 & 31 & 34.1 & 31 \\
\hline & BPORE & & Constant & & 1 & & 1 \\
\hline & DEPRATE & $\mathrm{X}$ & Triangular & 0.0126 & 0.014 & 0.0154 & 0.014 \\
\hline & FABOVE & & Triangular & 0.3 & 0.5 & 0.7 & 0.5 \\
\hline \multirow[t]{3}{*}{ periphyton } & BCF & $\mathrm{X}$ & Triangular & 414 & 460 & 506 & 460 \\
\hline & BPORE & & Constant & & 1 & & 0 \\
\hline & FABOVE & & Triangular & 0.45 & 0.5 & 0.55 & 0.5 \\
\hline \multirow{3}{*}{$\begin{array}{l}\text { phytoplankt } \\
\text { on }\end{array}$} & BCF & $\mathrm{X}$ & Triangular & 333 & 370 & 407 & 370 \\
\hline & BPORE & & Constant & & 0 & & 0 \\
\hline & FABOVE & & Constant & & 1 & & 1 \\
\hline
\end{tabular}




\subsection{Comparison of Measured Field Values to Laboratory Values Using ECEM}

The measured field values for the uptake of uranium in the soft tissues of Asian clams were compared to modeled body burdens using ECEM. In addition, the BCFs derived from the laboratory exposure studies for uranium/periphyton and uranium/clams are used in the model. The results are compared to the measured field values and the original ECEM parameters.

\subsection{Measured vs. Modeled Uranium Body Burdens in Asian Clams}

The ECEM model was run for 240 stochastic realizations to evaluate the range of uranium body burdens in clams that could occur given the range of input data. The input data for the stochastic assessment include: the stochastic environmental concentrations from Table 4.1, the non-stochastic species parameter data in Table 5.2, and the stochastic species parameter data in Table 5.3. A cumulative distribution function of the ECEM body burden results is shown in Figure 6.1, along with the measured clam tissue concentration data given in Table A.13 and the deterministic best estimate body burden result. The best estimate for a species parameter is the most representative value chosen from literature, which may be an average of several representative values. The best estimate value for environmental concentrations is the average measured value.

The measured clam body burdens ranged from $359 \mu \mathrm{g} / \mathrm{kg}$ dry to $37,350 \mu \mathrm{g} / \mathrm{kg}$ dry. The modeled stochastic body burden estimates ranged from $899 \mu \mathrm{g} / \mathrm{kg}$ dry to $161,000 \mu \mathrm{g} / \mathrm{kg}$ dry. The modeled best estimate body burden is $2360 \mu \mathrm{g} / \mathrm{kg}$ dry. For the best estimate case, $85.59 \%$ of the clam body burden is due to the exposure to water, $14.4 \%$ is due to food ingestion, and $0.01 \%$ is due to sediment ingestion.

Figure 6.1 shows that the best estimate is a little high in comparison to all the measured values and the range of the stochastic modeled results for body burden in the clams. Optimally, the best estimate would cross the measured and modeled body burdens at a cumulative probability of 0.5 . The modeled body burden results in particularly suggest that some parameters within ECEM could be improved. These parameters are associated with the values associated with calculating the body burden from water and food ingestion, including the BCF, assimilation efficiency (ALPHAIJ), and the depuration (DEPRATE). The next section uses the results from the laboratory (Section 3) and the field (Section 4) with the ECEM parameters (Section 5) to evaluate the results against the best estimate for body burden. Note that the experimental designs of the laboratory studies in Section 3 are not appropriate for evaluation of estimates of other ECEM parameters, e.g. assimilation efficiency and depuration.

\subsection{Application of Laboratory Exposure Studies to Modeled Body Burdens in Asian Clam}

The comparison of measured and modeled uranium body burdens in clams were evaluated by changing the BCF of the clam as well as changing the diet for the clams. Figure 6.2 summarizes the best estimate and stochastic results based on several changes to the ECEM's parameters. The results are compared to those used in the original model and discussed in Section 5 and Appendix B. 


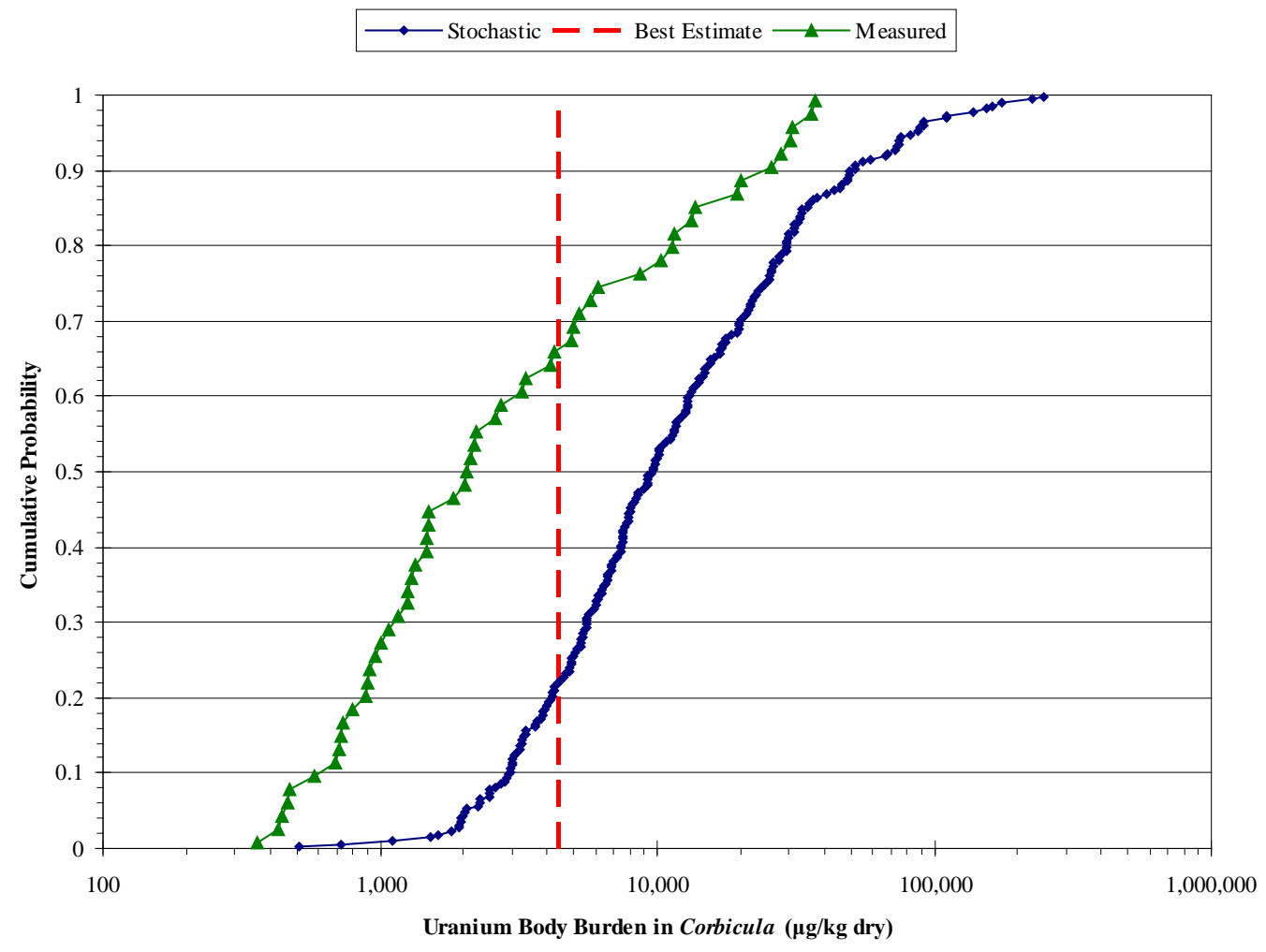

Figure 6.1. Comparison of Uranium Body Burden in Asian Clam, Measured and Modeled

In Figure 6.2, results are shown for modifications of the diet of the clam as well as for modification of the BCF. As discussed in Sections 1.2 and 4.3, the clam can have a varied diet, including phytoplankton, periphyton, and other invertebrates, and this diet was used in the stochastic results that are shown in the figure and labeled "Original Model" and "Modified BCF". The BCFs for the "Original Model" are from the literature (Miley et al. 2006) and are listed in Table 5.3. The BCFs for uranium and clams in the "Modified BCF" results are from the laboratory studies, and are shown in Figure 3.12. The abiotic media concentrations are the same as those in Table 4.1.

The diet for the clam was changed to look at the uranium body burdens based on 100\% consumption of periphyton. The laboratory results for the periphyton BCFs were included in the model as well as the laboratory results for the clam BCFs (Figure 3.11 and Figure 3.12). The abiotic media concentrations are the same as those in Table 4.1. The stochastic results are called "Modified BCF \& Diet" and the most reasonable estimate is called "Best Estimate - Diet \& BCF". These results are more than one order of magnitude greater than the original results due to the significantly higher periphyton BCFs from the laboratory studies (Figure 3.11) compared to the literature values (Table 5.3).

The stochastic results in the "Modified BCF" are slightly better than the stochastic results shown in the "Original Model" in comparison to "Field Measurements". However, there is a tradeoff in where the stochastic results intersect the "Modified Best Estimate" line and neither the measured nor the modified BCF are closer to 0.5 on the cumulative probability axis. 
Finally, the water concentrations were modified to match the conditions used in the laboratory exposures (Table 3.2 and Table 3.4). The periphyton and clam BCFs developed in the laboratory studies were used in this evaluation and summarized in the results shown as "Modified BCF \& Diet". The stochastic results for the uranium body burden in Corbicula were less than those for the field measured values. There is a plateau in the results around 500 to $1000 \mu \mathrm{g} / \mathrm{kg}$ dry body uranium body burden that is related to the concentrations in the water used in the exposure study. The highest concentrations evaluated are above 0.56 cumulative probability, whereas the lowest concentrations are represented in the stochastic results that are less than 0.55 cumulative probability. This is related to the concentrationdependent BCF results illustrated in Figure 3.12.

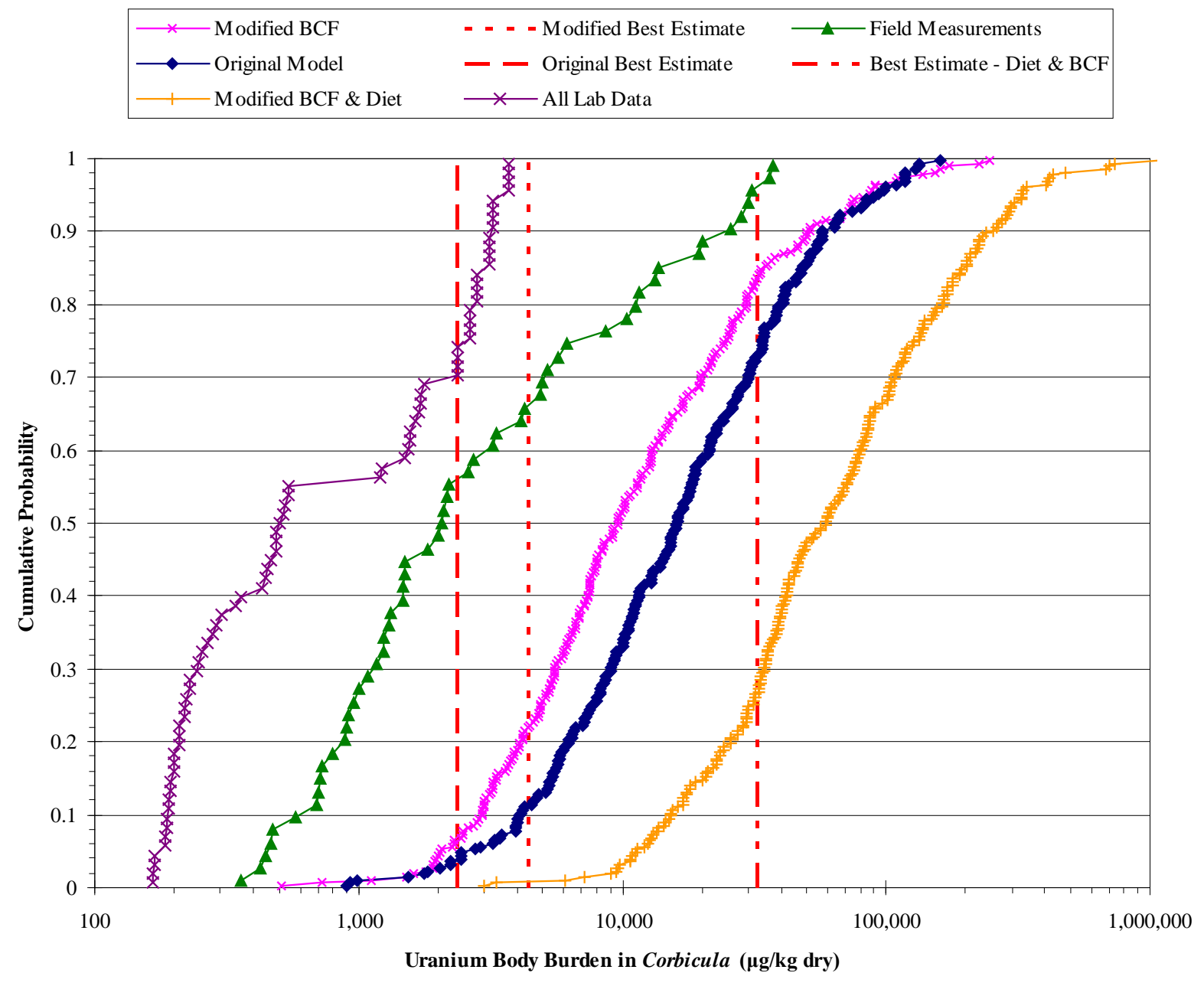

Figure 6.2. Comparison of Uranium Body Burden in Corbicula with Laboratory-Derived Parameters 



\subsection{Conclusions}

This report is a summary of efforts to provide site-specific parameters for evaluating ecological risk to aquatic organisms in the Hanford Reach of the Columbia River and Hanford-derived contaminants entering the river system. There are several conclusions that are important for consideration in environmental remediation at the Hanford Site based on the collection of measured field data, laboratory exposure studies, and evaluation of both data sets with ecological risk models.

Collection of biota and measured concentrations of contaminants in the environmental media should be co-located in order to interpret the concentration in the biota's tissues with the exposure conditions in the field. The home range of an organism is often greater than the point where a water or sediment sample is collected. Yet without collection of the environmental media, there is great uncertainty in the quality of the environment that leads to the accumulation of contaminants in biota. The environmental monitoring programs at the Hanford Site have started co-locating samples, which will lead to decreased uncertainty in future risk assessments.

The laboratory exposure studies (Section 3) have shown that periphyton accumulates uranium readily, yet there is little evidence that the uranium is impacting the organisms. Measures of biomass and chlorophyll production were used to investigate impacts of uranium exposure on periphyton. Productivity as measured by biomass was not affected by concentrations up to $100 \mu \mathrm{g} / \mathrm{L}$ uranium. Chlorophyll concentration was not found to change based on uranium concentration in the water.

The absence of apparent impacts to the periphyton community from exposure to uranium discussed in this report contrasts with results published in the literature on species of algae that are found in the water column. Studies on single algal species in suspension have shown growth rate inhibition, as determined by cell density, at $72 \mathrm{hr}$ between minimum detectable effect concentrations of $1.7 \mu \mathrm{g} / \mathrm{L}$ uranium with a water hardness of $40 \mathrm{mg} / \mathrm{L}$ as $\mathrm{CaCO}_{3}, \mathrm{pH}=7$, and $4.4 \mu \mathrm{g} / \mathrm{L}$ uranium with a water hardness of $100 \mathrm{mg} / \mathrm{L}$ as $\mathrm{CaCO}_{3}, \mathrm{pH}=7$ (Charles et al. 2002). Uranium growth inhibition on cultures of Chlorella sp. is also affected by pH. Franklin et al. (2000) found a $72 \mathrm{hr}$ growth inhibition minimum detectable effect concentration of $34 \mu \mathrm{g} / \mathrm{L}$ uranium at $\mathrm{pH}=5.7$, but an increase in $\mathrm{pH}$ to 6.5 produced a lower EC50 of $13 \mu \mathrm{g} / \mathrm{L}$ uranium (at water hardness of $2-4 \mathrm{mg} / \mathrm{L}$ as $\mathrm{CaCO}_{3}$ ).

There are no federal standards for uranium and aquatic organisms. Sheppard et al. 2005 derived a "predicted no-effect concentration" for uranium chemical toxicity to freshwater aquatic plants, e.g., periphyton, $5 \mu \mathrm{g} / \mathrm{L}$ in water based on the results of Charles et al. (2002) and Franklin et al. (2000). This is almost 2 orders of magnitude lower than the concentrations in the laboratory exposure studies reported in this report (Section 3), and significantly less than the $30 \mu \mathrm{g} / \mathrm{L}$ federal drinking water standard for protection of human health (EPA 2000). The elevated water hardness and $\mathrm{pH}$ of the exposure studies with Columbia River water may have effectively increased the minimum detectable effect concentration in the periphyton community. Water hardness in the exposure studies with Columbia River water and periphyton was $52 \pm 5 \mathrm{mg} / \mathrm{L}$ as $\mathrm{CaCO}_{3}$, and the $\mathrm{pH}$ averaged $9.16 \pm 0.16$ in all the exposure studies. This illustrates the need for performing site-specific studies in support of environmental remediation activities.

Uptake of uranium in aquatic biota is a function of the environmental conditions as well as the speciation and geochemistry of the element itself. BCFs for uranium uptake by the periphyton community ranged over 2 orders of magnitude (Figure 3.11), and the average was an order of magnitude 
greater than the most representative value used in ECEM (Table 5.3). There appeared to be a correlation between uptake of uranium in periphyton and water chemistry, but not strong enough to suggest using a non-steady state model to estimate body burdens for periphyton. Further investigation of the uranium speciation might reveal correlations in the BCF to changing conditions. Water in the periphyton exposure system is influenced by the photosynthesis of the community, ranging from $\mathrm{pH} 7$ when lights are off to $\sim \mathrm{pH} 10$ after the lights have been on for most of the photo period (data not shown). Several uranium complexes with carbonates are known to change over this $\mathrm{pH}$ range (Figure 2.1). This information could be used for adapting the calculation of uranium body burdens in ECEM, improving the modeled results in comparison to measured field results.

The results of the Asian clam exposure studies indicated that uptake of uranium in the soft tissue was dependent on the water concentration. This has implications for evaluating clams as a sentinel species in biomonitoring as well as in the use of current models for estimating body burdens. The distribution of measured concentrations in clams collected from the Hanford Reach ranges over 2 orders of magnitude. Since co-located water samples were not collected when the clams were sampled, it is not clear if there is a direct correlation with high soft tissue concentrations and pore water concentrations. However, the laboratory exposure studies indicate that such a correlation should exist, but not enough data has been collected to propose a new method for estimating the body burdens. In addition, the results from adding laboratory exposure conditions to ECEM in order to improve the prediction of body burden showed that the BCF is not the most sensitive parameter.

The next steps for improving the model estimates of uranium body burdens include evaluating the depuration rates from the laboratory exposure studies and investigating the models' sensitivity to changes in other assimilation parameters (e.g., ALPHAIJ). Results indicate that the uptake of uranium through the food chain to Asian clams is not well understood. The organisms that the clams are consuming are not included in current biomonitoring programs. The keys parameters for evaluating clams as a sentinel species still need to be investigated. 


\subsection{References}

40 CFR 192. "Health and Environmental Protection Standards for Uranium and Thorium Mill Tailings" U.S. Code of Federal Regulations. Available URL: http://www.epa.gov/superfund/health/conmedia/soil/cleanup.htm.

Arnot, JA, and FAPC Gobas. 2004. A food web bioaccumulation model for organic chemicals in aquatic ecosystems. Environmental Toxicology and Chemistry, 23:2343-2355.

Baker, DA, and JK Soldat. 1992. Methods for Estimating Doses to Organisms from Radioactive Materials Released into the Aquatic Environment. PNL-8150. Pacific Northwest National Laboratory, Richland, WA.

Becker, CD. 1990. Aquatic Bioenvironmental Studies: The Hanford Experience 1944-84. Studies in Environmental Science 39. Elsevier, Amsterdam, The Netherlands.

Bryce, RW, CT Kincaid, PW Eslinger, and LF Morasch LF, eds. 2002. An Initial Sssessment of Hanford Impact Performed with the System Assessment Capability. PNNL-14027. Pacific Northwest National Laboratory, Richland, WA.

Bunn, AL, JA Small, CA McKinstry, RE Durham, BM Miller, JA Stegen, DL Saunders, JM Brandenberger, A Dohnalkova, V Bailey, JK Magnuson, SE Baker, and EA Panisko. 2007. Periphyton Community Response to Environmentally Relevant Uranium Concentrations Evaluated Using Ecotoxicological, Electron Microscopy and Molecular Methods. Presented at Society for Environmental Toxicology and Chemistry, Europe, 17th Annual Meeting, May 20-25, Porto, Portugal.

CH2M HILL. 2001. Development of terrestrial exposure and bioaccumulation information for the Army Risk Assessment Modeling System (ARAMS). DAAD050-00-P-8365. U.S. Army Center for Health Promotion and Preventive Medicine, Aberdeen Proving Ground, MD.

Charles, AL, SJ Markich, JL Stauber, and LF De Filippis. 2002. The effect of water hardness on the toxicity of uranium to a tropical freshwater alga (Chlorella sp.). Aquatic Toxicology, 60:61-73.

Cherry, DS, and DJ Soucek. 2007. Case Study: Comparison of Asian Clam (Corbicula fluminea) in Situ Testing to Several Nontarget Test Organism Responses to Biocidal Dosing at a Nuclear Power Plant. In Farris, JL, and JH Van Hassel, eds. Freshwater Bivalve Ecotocicology. Society of Environmental Toxicology and Chemistry, Pensacola, FL.

Clesceri, LS, AE Greenberg, and AD Eaton, eds. 1998. Standard Methods for the Examination of Water and Wastewater. $20^{\text {th }}$ Edition. American Public Health Association, Washington, DC.

Cushing C.E., Allan J.D. 2001. Streams: Their Ecology and Life. Academic Press, Philadelphia, PA.

DOE. 1998. Columbia River Comprehensive Impact Assessment: Screening Assessment and Requirements for a Complete Assessment. DOE-RL 96-16 Rev. 1, U.S. Department of Energy, Richland, WA. 
DOE. 2004. Risk Assessment Work Plan for the 100 Area and 300 Area Component of the RCBRA. DOE/RL-2004-37, Rev. 2. U.S. Department of Energy, Richland Operations Office, Richland, WA.

DOE. 2005. Work Plan for Phase III Feasibility Study, 300-FF-5 Operable Unit. DOE/RL-2005-41, Rev. 0. U.S. Department of Energy, Richland, Washington.

DOE. 2006a. Aquatic and Riparian Receptor Impact Information for the 100-NR-2 Groundwater Operable Unit. DOE/RL-2006-26, Draft A, Re-Issue, U.S. Department of Energy, Richland, WA.

DOE. 2006b. Remedial Investigation Report for the 200-ZP-1 Groundwater Operable Unit. DOE/RL 2006-24, Rev. 0. U.S. Department of Energy, Richland Operations Office, Richland, WA.

Duncan, J.P., ed. 2007. Hanford Site National Environmental Policy Act (NEPA) Characterization. PNL-6415, Rev. 18. Pacific Northwest National Laboratory, Richland, WA.

EPA. 1996. Record of Decision for USDOE Hanford 300-FF-1 and 300-FF-5 Operable Units Remedial Actions. Agreement Between U.S. Department of Energy and U.S. Environmental Protection Agency, with Concurrence by the Washington State Department of Ecology, July 17, 1996.

EPA. 1999. Screening level ecological risk assessment protocol for hazardous waste combustion facilities. EPA/530-D-99-001A. U.S. Environmental Protection Agency Office of Solid Waste and Emergency Response, Washington, D.C.

EPA. 2000. National Primary Drinking Water Regulations; Radionuclides. Final Rule. 65 FR 236. December 7, 2000.

EPA. 2001a. USDOE Hanford Site: First Five Year Review Report. April 2001. Prepared by U.S. Environmental Protection Agency, Region 10, Hanford Project Office, Richland, Washington.

EPA. 2001b. Method 200.7: Trace Elements in Water, Solids and Biosolids by Inductively Coupled Plasma-Atomic Emission Spectrometry. Rev. 5. EPA-821-R-01-010. U.S. Environmental Protection Agency, Washington, D.C.

Eslinger, PW, C Arimescu, BA Kanyid, and TB Miley. 2002. User Instructions for the Systems Assessment Capability, Rev. 1, Computer Codes. Volume 2 Revised: Impact Modules. PNNL-13932Volume 2 Revised. Pacific Northwest National Laboratory, Richland, WA.

Eslinger, PW, TB Miley, C Arimescu, and BA Kanyid. 2006. User Instructions for the Systems Assessment Capability, Rev. 1, Computer Codes. Volume 2: Impact Modules. PNNL-14852, Volume 2, Pacific Northwest National Laboratory, Richland, WA.

Farris, JL, and JH Van Hassel. 2007. Freshwater Bivalve Ecotocicology. Society of Environmental Toxicology and Chemistry, Pensacola, FL.

Franklin, NM, JL Stauber, SJ Markich, and RP Lim. 2000. pH-dependent toxicity of copper and uranium to a tropical freshwater alga (Chlorella sp.). Aquatic Toxicology, 48:275-289. 
Freeman, S, M McVey, S Norton, and L Rao. 2004. Wildlife Scenario Builder of the Wildlife Contaminants Exposure Model. U.S. Environmental Protection Agency, National Center for Environmental Assessment, Washington, D.C.

Fritz BG, NP Kohn, TJ Gilmore, D McFarland, EV Arntzen, RD Mackley, GW Patton, DP Mendoza, and AL Bunn. 2007. Investigation of the Hyporheic Zone at the 300 Area, Hanford Site. PNNL-16805, Pacific Northwest National Laboratory, Richland, WA.

Gobas, FAPC, JP Pasternak, K Lien, and RK Duncan. 1998. Development and field validation of a multimedia exposure assessment model for waste load allocation in aquatic ecosystems: application to 2,3,7,8-tetrachlorodibenzo-p-dioxin and 2,3,7,8-tetrachlorodibenzofuran in the Fraser River watershed. Environmental Science and Technology, 32:2442-2449.

Guckert, JB, SC Nold, HL Boston, and DC White. 1992. Periphyton Response in an Industrial Receiving Stream - Lipid-Based Physiological Stress-Analysis and Pattern-Recognition of Microbial Community Structure. Can. J. Fish. Aquat. Sci., 49(12):2579-2587.

Hartman, MJ, LF Morasch, and WD Webber, eds. 2007. Hanford Site Groundwater Monitoring for Fiscal Year 2006. PNNL-16346, Pacific Northwest National Laboratory, Richland, WA.

Hill, BH, AT Herlihy, PR Kaufmann, RJ Stevenson, FH McCormick, and CB Johnson. 2000. Use of periphyton assemblage data as an index of biotic integrity. Journal of the North American Benthological Society, 19(1):50-67.

Kent, RA, T Crommentuijn, CW Hickey, and FJ Keating, Jr. 2003. A Review of Current Approaches and Furture Directions in National Ambient Water-Quality Criteria for Aquatic Life Protection: Canada, Netherlands, New Zealand, USA. In Reiley MC, WA Stubblefield, WJ Adams, DM Di Toro, PV Hodson, RJ Erickson, and FJ Keating, Jr., eds. Reevaluation of the State of Science for Water-Quality Criteria Development. Society of Environmental Toxicology and Chemistry, Pensacola, FL.

Kim, JL, DS Rhee, H Wimmer, G Buckau, and R Klenze. 1993. Complexation of Trivalent Actinide Ions $\left(\mathrm{Am}^{3+}, \mathrm{Cm}^{3+}\right)$ with Humic Acid: A Comparison of Different Experimental Methods. Radiochimica. Acta., 62:35-43.

Layton, D, M Varela, R Edson, and BA Napier. 1997. Radionuclides in arctic seas from the former soviet union: potential health and ecological risks. Arctic Nuclear Waste Assessment Program, Office of Naval Research, Washington, D.C.

MESO. 2004. Hydrodynamic and Watershed Modeling Resources on the Internet. Marine Environmental Support Office, Department of the Navy, Space and Naval Warfare Systems Center, San Diego, CA. Available at: http://meso.spawar.navy.mil/modeling.html

Miley TB, AL Bunn, BA Napier, PW Eslinger, and CA Brandt. 2006. Ecological and Human Health Risk Data Package for Hanford Assessments. PNNL-15907, Pacific Northwest National Laboratory, Richland, WA.

Miley, TB, AL Bunn, BA Napier, RE Peterson, and JM Becker. 2007. 300-FF-5 Operable Unit Current Conditions Risk Assessment . PNNL-16454. Pacific Northwest National Laboratory, Richland, WA. 
Napier, BA, DL Strenge, JV Ramsdell, Jr, PW Eslinger, and CJ Fosmire. 2002. GENII version 2: software design document. PNNL-14584. Pacific Northwest National Laboratory, Richland, WA.

Neitzel, D. A., ed. 2005. Hanford Site National Environmental Policy Act (NEPA) Characterization. PNL-6415, Rev. 17. Pacific Northwest National Laboratory, Richland, Washington.

Ng, YC, CS Colsher, and SE Thompson. 1982. Transfer coefficients for assessing the dose from radionuclides in meat and eggs: Final report. NUREG/CR-2976. US Nuclear Regulatory Commission, Washington, DC.

Palms, J, R Patrick, D Kreeger, and C Harris. 2007. 25-Y Study of Radionuclide Monitoring with Terrestrial and Aquatic Biomonitors. Health Physics, 92:219-225.

Patton GW, SP Van Verst, BL Tiller, EJ Antonio, and TM Poston. 2003. Survey of Radiological and Chemical Contaminants in the Near-Shore Environment at the Hanford Site 300 Area. PNNL-13692 Rev. 1, Pacific Northwest National Laboratory, Richland, Washington.

Peterson RE, and MP Connelly. 2001. Zone of Interaction Between Hanford Site Groundwater and Adjacent Columbia River. PNNL-13674, Pacific Northwest National Laboratory, Richland, WA.

Pennack, RW. 1989. Freshwater Invertebrates of the US. 3rd Edition. John Wiley \& Sons, New York, New York.

Poston, TM, RW Hanf, Jr, JP Duncan and RL Dirkes, eds. 2007. Hanford Site Environmental Report for Calendar Year 2006. PNNL-16623. Pacific Northwest National Laboratory, Richland, WA.

Robertson, DE, DA Cataldo, BA Napier, KM Krupka, and LB Sasser. 2003. Literature Review and Assessment of Plant and Animal Transfer Factors Used in Performance Assessment Modeling. NUREG/CR-6825, PNNL-14321, Pacific Northwest National Laboratory, Richland, WA.

Sandino, A, and J Bruno. 1992. The Solubility of $\left(\mathrm{UO}_{2}\right)_{3}\left(\mathrm{PO}_{4}\right)_{2} \cdot 4 \mathrm{H}_{2} \mathrm{O}(\mathrm{s})$ and the Formation of U(VI) Phosphate Complexes: Their Influence in Uranium Speciation in Natural Waters. Geochimica. et Cosmochimica. Acta., 56:4135-4145.

Sheppard, SC, MI Sheppard, MO Gallerand, and B Sanipelli. 2005. Derivation of ecotoxicity thresholds for uranium. Journal of Environmental Radioactivity, 79(1):55-83.

Small, JA, AL Bunn, CA McKinstry, AD Peacock, and AL Miracle. 2007. Investigating Freshwater Periphyton Community Response to Uranium with Phospholipid Fatty Acid and Denaturing Gradient Gel Electrophoresis Analyses. Journal of Environmental Radioactivity, in press.

Suter, GW. 1996. Toxicological Benchmarks for Screening Contaminants of Potential Concern for Effects on Freshwater Biota. Environmental Toxicology and Chemistry, 15(7):1232-1241

Thomann, RV. 1989. Bioaccumulation model of organic chemical distribution in aquatic food chains. Environmental Science and Technology, 23:699-707. 
Thomann, RV, JP Connolly, and TF Parkerton. 1992. An equilibrium model of organic chemical accumulation in aquatic food webs with sediment interaction. Environmental Toxicology and Chemistry 11:615-629.

Thomann, RV, JD Mahony, and R Mueller. 1995. Steady-state model of biota sediment accumulation factor for metals in two marine bivalves. Environmental Toxicology and Chemistry, 14(11):1989-1998.

Thomann, RV. 1998. The future "golden age" of predictive models for surface water quality and ecosystem management. Journal of Environmental Engineering, 124(2):94-103.

Vadeboncoeur, Y, KS McCann, MJ VanderZanden, and JB Rasmussen. 2005. Effects of multi-chain omnivory on the strength of trophic control in lakes. Ecosystems, 8(6):682-693.

Von Stackelberg, KE, WT Wickwire, and D Burmistrov. 2005. Spatially-explicit wildlife exposure modeling tools for use in human health and ecological risk assessment: SEEM and FISHRANDmigration. WIT Transactions on Ecology and the Environment, 85:279-289.

Wu, DW. 2003. Biosphere model report. MDL-MGR-MD-000001 REV 00. Bechtel SAIC Co, Inc. Las Vegas, NV.

Zachara, J.M., ed. 2005. Uranium Geochemistry in Vadose Zone and Aquifer Sediments from the 300 Area Uranium Plume. PNNL-15121, Pacific Northwest National Laboratory, Richland, Washington.

Zachara JM, CF Brown, JN Christensen, JA Davis, PE Dresel, C Liu, SD Kelly, JP McKinley, RJ Serne, and W Um. 2007. A Site Wide Perspective on Uranium Geochemistry at the Hanford Site. PNNL17031, Pacific Northwest National Laboratory, Richland, WA.

Zakikhani, M, DL Brandon, MS Dortch, and JA Gerald. 2006. Demonstration Applications of ARAMS for Aquatic and Terrestrial Ecological Risk Assessment. ERDC/EL TR-06-1. U.S. Army Corps of Engineers, Engineeer Research and Development Center, Vicksburg, MS. 



\section{Appendix A}

\section{Data for Modeling Uptake by Aquatic Food Chain}





\section{Appendix A - Data for Modeling Uptake by Aquatic Food Chain}

The data for modeling the uptake by aquatic food chain were provided by the Surface Environmental Surveillance Project (SESP). All uranium data used in this assessment are available in the Hanford Environmental Information System (HEIS), including chemical and isotopic analyses for uranium. Data were gathered from 1994 through 2005. Figure 2.4 in Section 2 of this report shows the various media from which data were collected. The maximum value for each contaminant/medium combination is identified in the corresponding data plot. The line in the data table corresponding to the maximum value is shown in bold text.

\section{A.1 Surface Water Data}

The surface water data were provided by staff from SESP. Data were provided for the 300 Area vicinity and for the Richland Pumphouse location at the end of Snyder Street in Richland, Washington.

\section{A.1.1 Uranium Surface Water Data}

There were five surface water samples of uranium at the 300 Area location and none at the Richland Pumphouse location. The samples were collected between 6/10/2004 and 9/15/2005. The values are plotted in Figure A.1, and the data are presented in Table A.1.

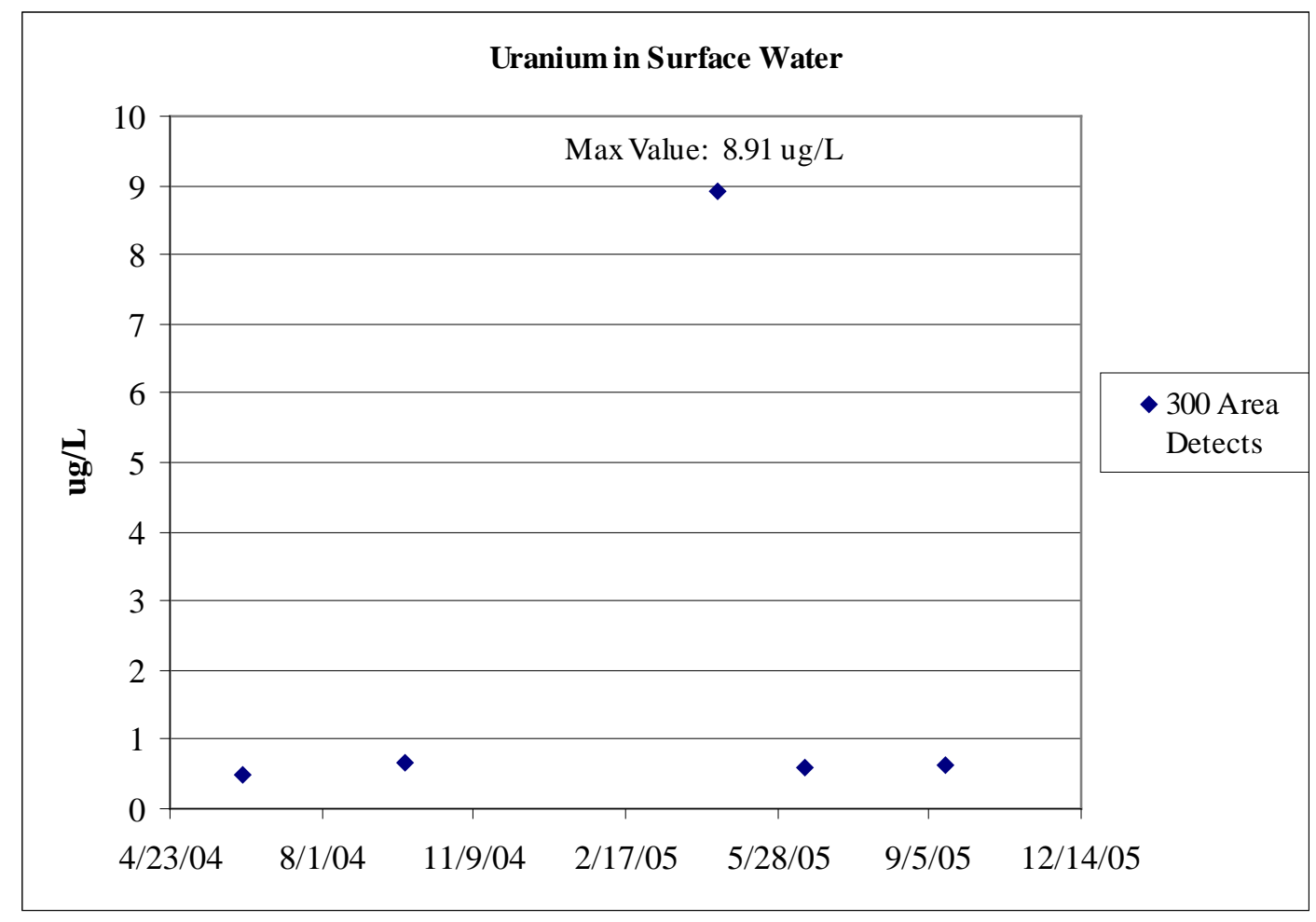

Figure A.1. Uranium in Surface Water 
Table A.1. Uranium Data in Surface Water

\begin{tabular}{|c|c|c|c|c|c|c|c|}
\hline Analyte & Location & $\begin{array}{c}\text { Sample } \\
\text { Number }\end{array}$ & $\begin{array}{c}\text { Sampled } \\
\text { From } \\
\end{array}$ & $\begin{array}{c}\text { Filtered } \\
\text { Flag } \\
\end{array}$ & $\begin{array}{c}\text { Sample } \\
\text { Date }\end{array}$ & $\begin{array}{l}\text { Value } \\
(\mu \mathrm{g} / \mathrm{L}) \\
\end{array}$ & Quali-fier \\
\hline Uranium & 300 Area & & River & $\mathrm{Y}$ & $6 / 10 / 04$ & 0.482 & $\mathrm{X}$ \\
\hline Uranium & 300 Area & & River & $\mathrm{N}$ & $9 / 24 / 04$ & 0.647 & $\mathrm{X}$ \\
\hline Uranium & 300 Area & & River & $\mathrm{Y}$ & $4 / 19 / 05$ & 8.91 & $\mathrm{X}$ \\
\hline Uranium & 300 Area & & River & $\mathrm{Y}$ & $6 / 15 / 05$ & 0.609 & $\mathrm{X}$ \\
\hline Uranium & 300 Area & & River & $\mathrm{Y}$ & $9 / 15 / 05$ & 0.615 & $\mathrm{X}$ \\
\hline
\end{tabular}

\section{A.1.2 Uranium-234 Surface Water Data}

There were 164 surface water samples of uranium-234 at the 300 Area location and none at the Richland Pumphouse location. The samples were collected between 3/29/1994 and 12/19/2004. The values are plotted in Figure A.2 and the data are presented in Table A.2.

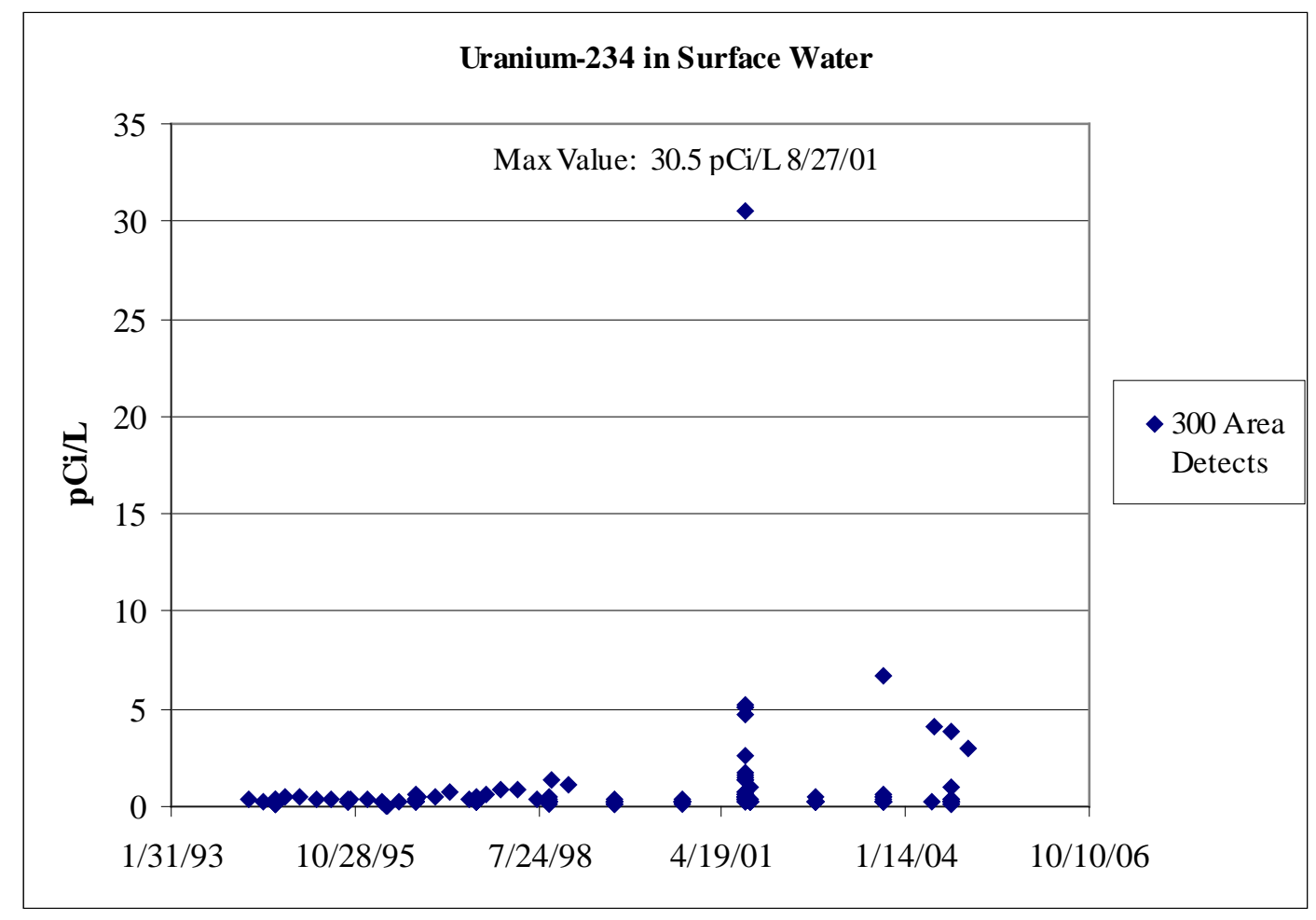

Figure A.2. Uranium-234 in Surface Water 
Table A.2. Uranium-234 Data in Surface Water

\begin{tabular}{|c|c|c|c|c|c|c|c|c|c|}
\hline Analyte & Location & $\begin{array}{l}\text { Sample } \\
\text { Number }\end{array}$ & $\begin{array}{c}\text { Sampled } \\
\text { From }\end{array}$ & $\begin{array}{c}\text { Filter } \\
\text { Flag } \\
\end{array}$ & $\begin{array}{c}\text { Sample } \\
\text { Date }\end{array}$ & $\begin{array}{c}\text { Value } \\
(\mathrm{pCi} / \mathrm{L})\end{array}$ & \begin{tabular}{|c|}
$\begin{array}{c}\text { Counting } \\
\text { Error }\end{array}$ \\
\end{tabular} & MDA & \begin{tabular}{|l} 
Quali- \\
fier \\
\end{tabular} \\
\hline Uranium-234 & 331 Bldg. 300 Area & B0HRH1 & Drinking & $\mathrm{NN}$ & 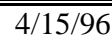 & 0.0565 & 0.0257 & & \\
\hline Uranium-234 & 300 Spr DR $9-4$ & B12T19 & River & $\mathrm{N}$ & $8 / 27 / 01$ & 0.315 & 0.042 & 0.00756 & \\
\hline Uranium-234 & 300 Spr DR 9 -3 & B12RV9 & River & $\mathrm{N}$ & $8 / 27 / 01$ & 1.67 & 0.095 & 0.0148 & \\
\hline Uranium-234 & 300 Spr DR 9 -2 & B12RV7 & River & $\mathrm{N}$ & $8 / 27 / 01$ & 5.27 & 0.18 & 0.0102 & \\
\hline Uranium-234 & 300 Spr DR 9 -1 & B12RV5 & River & $\mathrm{N}$ & $8 / 27 / 01$ & 4.7 & 0.16 & 0.0169 & \\
\hline Uranium-234 & 300 Spr DR 7 -4 & B12T15 & River & $\mathrm{N}$ & $8 / 27 / 01$ & 0.267 & 0.041 & 0.00866 & \\
\hline Uranium-234 & 300 Spr DR 7 -3 & B12RT5 & River & $\mathrm{N}$ & $8 / 27 / 01$ & 0.418 & 0.049 & 0.00946 & \\
\hline Uranium-234 & 300 Spr DR 7 -2 & B12RT3 & River & $\mathrm{N}$ & 8/27/01 & 0.606 & 0.057 & 0.00907 & \\
\hline Uranium-234 & 300 Spr DR 7 -1 & B12RT1 & River & $\mathrm{N}$ & 8/27/01 & 1.43 & 0.089 & 0.00779 & \\
\hline Uranium-234 & 300 Spr DR $11-4$ & B12T23 & River & $\mathrm{N}$ & $8 / 27 / 01$ & 0.384 & 0.054 & 0.0183 & \\
\hline Uranium-234 & 300 Spr DR $11-3$ & B12RX5 & River & $\mathrm{N}$ & 8/27/01 & 0.493 & 0.064 & 0.023 & \\
\hline Uranium-234 & 300 Spr DR $11-2$ & B12RX3 & River & $\mathrm{N}$ & $8 / 27 / 01$ & 0.652 & 0.061 & 0.00802 & \\
\hline Uranium-234 & 300 Spr DR $11-1$ & B12RX1 & River & $\mathrm{N}$ & $8 / 27 / 01$ & 2.59 & 0.12 & 0.0102 & \\
\hline Uranium-234 & 300 Spr 9 thru Spr 11 & B12RW1 & River & $\mathrm{N}$ & $8 / 27 / 01$ & 0.538 & 0.055 & 0.00778 & \\
\hline Uranium-234 & 300 Spr $9-4$ & B12T17 & River & $\mathrm{N}$ & $8 / 27 / 01$ & 0.263 & 0.046 & 0.0214 & \\
\hline Uranium-234 & 300 Spr $9-3$ & B12RV3 & River & $\mathrm{N}$ & $8 / 27 / 01$ & 0.356 & 0.052 & 0.0178 & \\
\hline Uranium-234 & 300 Spr $9-2$ & B12RV1 & River & $\mathrm{N}$ & $8 / 27 / 01$ & 1.31 & 0.11 & 0.0212 & \\
\hline Uranium-234 & 300 Spr 9 -1 & B12RT9 & River & $\mathbf{N}$ & $8 / 27 / 01$ & 30.5 & 0.42 & 0.00828 & \\
\hline Uranium-234 & 300 Spr 7 thru Spr 9 & B12RT7 & River & $\mathrm{N}$ & $8 / 27 / 01$ & 0.479 & 0.055 & 0.0107 & \\
\hline Uranium-234 & 300 Spr $7-4$ & $\mathrm{~B} 12 \mathrm{~T} 13$ & River & $\mathrm{N}$ & $8 / 27 / 01$ & 0.418 & 0.05 & 0.00836 & \\
\hline Uranium-234 & 300 Spr $7-3$ & B12RR9 & River & $\mathrm{N}$ & $8 / 27 / 01$ & 0.56 & 0.054 & 0.00348 & \\
\hline Uranium-234 & 300 Spr $7-2$ & B12RR7 & River & $\mathrm{N}$ & 8/27/01 & 1.77 & 0.1 & 0.0125 & \\
\hline Uranium-234 & 300 Spr $7-1$ & B12RR5 & River & $\mathrm{N}$ & $8 / 27 / 01$ & 5.14 & 0.17 & 0.00979 & \\
\hline Uranium-234 & 300 Spr $14-4$ & B12T25 & River & $\mathrm{N}$ & $8 / 27 / 01$ & 0.371 & 0.047 & 0.00801 & \\
\hline Uranium-234 & 300 Spr $14-3$ & B12RY3 & River & $\mathrm{N}$ & $8 / 27 / 01$ & 0.542 & 0.057 & 0.00825 & \\
\hline Uranium-234 & 300 Spr $14-2$ & B12RY1 & River & $\mathrm{N}$ & $8 / 27 / 01$ & 0.431 & 0.05 & 0.0148 & \\
\hline Uranium-234 & 300 Spr $14-1$ & B12RX9 & River & $\mathrm{N}$ & $8 / 27 / 01$ & 0.459 & 0.058 & 0.0207 & \\
\hline Uranium-234 & 300 Spr $11-4$ & B12T21 & River & $\mathrm{N}$ & $8 / 27 / 01$ & 0.719 & 0.064 & 0.00803 & \\
\hline Uranium-234 & 300 Spr $11-3$ & B12RW9 & River & $\mathrm{N}$ & $8 / 27 / 01$ & 1.39 & 0.086 & 0.00896 & \\
\hline Uranium-234 & 300 Spr $11-2$ & B12RW7 & River & $\mathrm{N}$ & $8 / 27 / 01$ & 0.703 & 0.061 & 0.00909 & \\
\hline Uranium-234 & 300 Spr $11-1$ & B12RW5 & River & $\mathrm{N}$ & $8 / 27 / 01$ & 5.05 & 0.16 & 0.0101 & \\
\hline Uranium-234 & 300 Area-10 HRM 43.1 & B0C5C6 & River & $\mathrm{N}$ & $8 / 26 / 94$ & 0.279 & 0.139 & & \\
\hline Uranium-234 & 300 Area-10 HRM 43.1 & B0G8B2 & River & $\mathrm{N}$ & $9 / 18 / 95$ & 0.322 & 0.0621 & & \\
\hline Uranium-234 & 300 Area-10 HRM 43.1 & B0J8Y6 & River & $\mathrm{N}$ & 9/20/96 & 0.421 & 0.0659 & & \\
\hline Uranium-234 & 300 Area-10 HRM 43.1 & B0LVW6 & River & $\mathrm{N}$ & $8 / 25 / 97$ & 0.464 & 0.0618 & & \\
\hline Uranium-234 & 300 Area-10 HRM 43.1 & B0PVR3 & River & $\mathrm{N}$ & $9 / 15 / 98$ & 0.451 & 0.114 & & \\
\hline Uranium-234 & 300 Area-10 HRM 43.1 & B0WB28 & River & $\mathrm{N}$ & $9 / 16 / 99$ & 0.368 & 0.05 & 0.0182 & \\
\hline Uranium-234 & 300 Area-10 HRM 43.1 & B106Y3 & River & $\mathrm{N}$ & $9 / 19 / 00$ & 0.296 & 0.044 & 0.0117 & \\
\hline Uranium-234 & 300 Area-10 HRM 43.1 & B12TC6 & River & $\mathrm{N}$ & $9 / 13 / 01$ & 0.972 & 0.077 & 0.00844 & \\
\hline Uranium-234 & 300 Area-10 HRM 43.1 & B158M0 & River & $\mathrm{N}$ & $9 / 10 / 02$ & 0.439 & 0.059 & 0.018 & \\
\hline Uranium-234 & 300 Area-10 HRM 43.1 & B17CK0 & River & $\mathrm{N}$ & $9 / 9 / 03$ & 0.467 & 0.059 & 0.0213 & \\
\hline Uranium-234 & 300 Area-10 HRM 43.1 & B1B725 & River & $\mathrm{N}$ & $9 / 15 / 04$ & 0.976 & 0.089 & 0.0146 & \\
\hline Uranium-234 & 300 Area Shr HRM42.9 & B0WB56 & River & $\mathrm{N}$ & $9 / 16 / 99$ & 0.181 & 0.037 & 0.0265 & \\
\hline Uranium-234 & 300 Area Shr HRM42.9 & B10782 & River & $\mathrm{N}$ & $9 / 19 / 00$ & 0.264 & 0.039 & 0.00405 & \\
\hline Uranium-234 & 300 Area Shr HRM42.9 & B12TR6 & River & $\mathrm{N}$ & $9 / 13 / 01$ & 0.249 & 0.038 & 0.00376 & \\
\hline Uranium-234 & 300 Area Shr HRM42.9 & B158Y9 & River & $\mathrm{N}$ & $9 / 10 / 02$ & 0.226 & 0.053 & 0.00808 & \\
\hline Uranium-234 & 300 Area Shr HRM42.9 & B17CX7 & River & $\mathrm{N}$ & $9 / 9 / 03$ & 0.601 & 0.056 & 0.012 & \\
\hline Uranium-234 & 300 Area Shr HRM42.9 & B1B7C7 & River & $\mathrm{N}$ & $9 / 15 / 04$ & 0.243 & 0.04 & 0.0116 & \\
\hline
\end{tabular}


Table A.2. (contd)

\begin{tabular}{|c|c|c|c|c|c|c|c|c|c|}
\hline Analyte & Location & $\begin{array}{c}\text { Sample } \\
\text { Number }\end{array}$ & $\begin{array}{l}\text { Sampled } \\
\text { From }\end{array}$ & $\begin{array}{l}\text { Filter } \\
\text { Flag }\end{array}$ & $\begin{array}{l}\text { Sample } \\
\text { Date }\end{array}$ & $\begin{array}{c}\text { Value } \\
\text { (pCi/L) }\end{array}$ & $\begin{array}{c}\text { Counting } \\
\text { Error }\end{array}$ & MDA & $\begin{array}{l}\text { Quali- } \\
\text { fier }\end{array}$ \\
\hline Uranium-234 & 300 Area Shr HRM42.5 & B0WB55 & River & $\mathrm{N}$ & 9/16/99 & 0.309 & 0.046 & 0.0119 & \\
\hline Uranium-234 & 300 Area Shr HRM42.5 & B10779 & River & $\mathrm{N}$ & 9/19/00 & 0.204 & 0.032 & 0.00749 & \\
\hline Uranium-234 & 300 Area Shr HRM42.5 & B12TR2 & River & $\mathrm{N}$ & 9/13/01 & 0.262 & 0.043 & 0.00943 & \\
\hline Uranium-234 & 300 Area Shr HRM42.5 & B158Y6 & River & $\mathrm{N}$ & 9/10/02 & 0.237 & 0.036 & 0.00358 & \\
\hline Uranium-234 & 300 Area Shr HRM42.5 & B17CX3 & River & $\mathrm{N}$ & 9/9/03 & 6.72 & 0.18 & 0.022 & \\
\hline Uranium-234 & 300 Area Shr HRM42.4 & B1B7H3 & River & $\mathrm{N}$ & 9/15/04 & 0.386 & 0.056 & 0.00541 & \\
\hline Uranium-234 & 300 Area Shr HRM42.1 & B0WB54 & River & $\mathrm{N}$ & 9/16/99 & 0.303 & 0.045 & 0.0182 & \\
\hline Uranium-234 & 300 Area Shr HRM42.1 & B10776 & River & $\mathrm{N}$ & 9/19/00 & 0.335 & 0.039 & 0.00924 & \\
\hline Uranium-234 & 300 Area Shr HRM42.1 & В12ТР8 & River & $\mathrm{N}$ & 9/13/01 & 0.351 & 0.045 & 0.0146 & \\
\hline Uranium-234 & 300 Area Shr HRM42.1 & B158Y3 & River & $\mathrm{N}$ & $9 / 10 / 02$ & 0.198 & 0.035 & 0.00823 & \\
\hline Uranium-234 & 300 Area Shr HRM42.1 & B17CW9 & River & $\mathrm{N}$ & 9/9/03 & 0.373 & 0.045 & 0.00988 & \\
\hline Uranium-234 & 300 Area Shr HRM42.1 & B1B7C3 & River & $\mathrm{N}$ & $9 / 15 / 04$ & 0.322 & 0.049 & 0.00495 & \\
\hline Uranium-234 & 300 Area Shr HRM41.5 & B0WB53 & River & $\mathrm{N}$ & 9/16/99 & 0.225 & 0.039 & 0.0161 & \\
\hline Uranium-234 & 300 Area Shr HRM41.5 & B10773 & River & $\mathrm{N}$ & $9 / 19 / 00$ & 0.196 & 0.037 & 0.0138 & \\
\hline Uranium-234 & 300 Area Shr HRM41.5 & B12TP4 & River & $\mathrm{N}$ & 9/13/01 & 0.249 & 0.046 & 0.0158 & \\
\hline Uranium-234 & 300 Area Shr HRM41.5 & B158Y0 & River & $\mathrm{N}$ & 9/10/02 & 0.214 & 0.04 & 0.0162 & \\
\hline Uranium-234 & 300 Area Shr HRM41.5 & B17CW5 & River & $\mathrm{N}$ & 9/9/03 & 0.27 & 0.039 & 0.0036 & \\
\hline Uranium-234 & 300 Area Shr HRM41.5 & B1B7B9 & River & $\mathrm{N}$ & 9/15/04 & 0.265 & 0.054 & 0.0071 & \\
\hline Uranium-234 & 300 Area Outfl13 & B19JC4 & River & $\mathrm{N}$ & $6 / 24 / 04$ & 4.07 & 0.19 & 0.0326 & \\
\hline Uranium-234 & 300 Area Outfl13 & B1B7H7 & River & $\mathrm{N}$ & 9/15/04 & 3.89 & 0.17 & 0.005 & \\
\hline Uranium-234 & 300 Area Outfl13 & B1BW54 & River & $\mathrm{N}$ & $12 / 19 / 04$ & 2.99 & 0.14 & 0.0267 & \\
\hline Uranium-234 & 300 Area -9 HRM 43.1 & B0C5C5 & River & $\mathrm{N}$ & 8/26/94 & 0.167 & 0.126 & & \\
\hline Uranium-234 & 300 Area -9 HRM 43.1 & B0G8B1 & River & $\mathrm{N}$ & 9/18/95 & 0.262 & 0.0515 & & \\
\hline Uranium-234 & 300 Area -9 HRM 43.1 & B0J8Y5 & River & $\mathrm{N}$ & 9/20/96 & 0.268 & 0.0506 & & \\
\hline Uranium-234 & 300 Area -9 HRM 43.1 & B0LVW5 & River & $\mathrm{N}$ & $8 / 25 / 97$ & 0.277 & 0.047 & & \\
\hline Uranium-234 & 300 Area -8 HRM 43.1 & B0C5C4 & River & $\mathrm{N}$ & $8 / 26 / 94$ & 0.356 & 0.114 & & \\
\hline Uranium-234 & 300 Area -8 HRM 43.1 & B0G8B0 & River & $\mathrm{N}$ & 9/18/95 & 0.305 & 0.0536 & & \\
\hline Uranium-234 & 300 Area -8 HRM 43.1 & B0J8Y4 & River & $\mathrm{N}$ & 9/20/96 & 0.231 & 0.0454 & & \\
\hline Uranium-234 & 300 Area -8 HRM 43.1 & B0LVW4 & River & $\mathrm{N}$ & $8 / 25 / 97$ & 0.298 & 0.0492 & & \\
\hline Uranium-234 & 300 Area -8 HRM 43.1 & B0PVR1 & River & $\mathrm{N}$ & 9/15/98 & 0.224 & 0.0505 & & \\
\hline Uranium-234 & 300 Area -7 HRM 43.1 & B0C5C3 & River & $\mathrm{N}$ & $8 / 26 / 94$ & 0.16 & 0.0798 & & \\
\hline Uranium-234 & 300 Area -7 HRM 43.1 & B0G899 & River & $\mathrm{N}$ & 9/18/95 & 0.287 & 0.0543 & & \\
\hline Uranium-234 & 300 Area -7 HRM 43.1 & B0J8Y3 & River & $\mathrm{N}$ & 9/20/96 & 0.299 & 0.0609 & & \\
\hline Uranium-234 & 300 Area -7 HRM 43.1 & B0LVW3 & River & $\mathrm{N}$ & $8 / 25 / 97$ & 0.277 & 0.0498 & & \\
\hline Uranium-234 & 300 Area -7 HRM 43.1 & B0PVR0 & River & $\mathrm{N}$ & 9/15/98 & 0.347 & 0.119 & & \\
\hline Uranium-234 & 300 Area -7 HRM 43.1 & B0WB27 & River & $\mathrm{N}$ & 9/16/99 & 0.203 & 0.036 & 0.0116 & \\
\hline Uranium-234 & 300 Area -7 HRM 43.1 & B106Y1 & River & $\mathrm{N}$ & $9 / 19 / 00$ & 0.21 & 0.039 & 0.0171 & \\
\hline Uranium-234 & 300 Area -7 HRM 43.1 & B12TC4 & River & $\mathrm{N}$ & 9/13/01 & 0.234 & 0.038 & 0.00822 & \\
\hline Uranium-234 & 300 Area -7 HRM 43.1 & B158L9 & River & $\mathrm{N}$ & 9/10/02 & 0.293 & 0.049 & 0.00542 & \\
\hline Uranium-234 & 300 Area -7 HRM 43.1 & B17CJ8 & River & $\mathrm{N}$ & 9/9/03 & 0.252 & 0.038 & 0.00799 & \\
\hline Uranium-234 & 300 Area -7 HRM 43.1 & B1B724 & River & $\mathrm{N}$ & 9/15/04 & 0.297 & 0.055 & 0.0257 & \\
\hline Uranium-234 & 300 Area -6 HRM 43.1 & B0C5C2 & River & $\mathrm{N}$ & 8/26/94 & 0.168 & 0.0802 & & \\
\hline Uranium-234 & 300 Area -6 HRM 43.1 & B0G898 & River & $\mathrm{N}$ & 9/18/95 & 0.264 & 0.0504 & & \\
\hline Uranium-234 & 300 Area -6 HRM 43.1 & B0J8Y2 & River & $\mathrm{N}$ & 9/20/96 & 0.308 & 0.0563 & & \\
\hline Uranium-234 & 300 Area -6 HRM 43.1 & B0LVW2 & River & $\mathrm{N}$ & $8 / 25 / 97$ & 0.239 & 0.0421 & & \\
\hline Uranium-234 & 300 Area -5 HRM 43.1 & B0C5C1 & River & $\mathrm{N}$ & $8 / 26 / 94$ & 0.237 & 0.071 & & \\
\hline Uranium-234 & 300 Area -5 HRM 43.1 & B0G897 & River & $\mathrm{N}$ & 9/18/95 & 0.221 & 0.0519 & & \\
\hline Uranium-234 & 300 Area -5 HRM 43.1 & B0J8Y0 & River & $\mathrm{N}$ & 9/20/96 & 0.198 & 0.0401 & & \\
\hline Uranium-234 & 300 Area -5 HRM 43.1 & B0LVW1 & River & $\mathrm{N}$ & 8/25/97 & 0.266 & 0.0476 & & \\
\hline Uranium-234 & 300 Area -5 HRM 43.1 & B0PVP8 & River & $\mathrm{N}$ & 9/15/98 & 0.195 & 0.0442 & & \\
\hline
\end{tabular}


Table A.2. (contd)

\begin{tabular}{|c|c|c|c|c|c|c|c|c|c|}
\hline Analyte & Location & $\begin{array}{c}\text { Sample } \\
\text { Number }\end{array}$ & $\begin{array}{c}\text { Sampled } \\
\text { From }\end{array}$ & $\begin{array}{c}\text { Filter } \\
\text { Flag }\end{array}$ & $\begin{array}{c}\text { Sample } \\
\text { Date }\end{array}$ & $\begin{array}{c}\text { Value } \\
(\mathrm{pCi} / \mathrm{L})\end{array}$ & \begin{tabular}{|c|} 
Counting \\
Error
\end{tabular} & MDA & \begin{tabular}{|c} 
Quali- \\
fier
\end{tabular} \\
\hline Uranium-234 & 300 Area -5 HRM 43.1 & $\overline{\text { B0WB26 }}$ & River & $\overline{\mathrm{N}}$ & 9/16/99 & 0.166 & 0.036 & 0.0265 & \\
\hline Uranium-234 & 300 Area -5 HRM 43.1 & B106X9 & River & $\mathrm{N}$ & $9 / 19 / 00$ & 0.197 & 0.039 & 0.0209 & \\
\hline Uranium-234 & 300 Area -5 HRM 43.1 & B12TC2 & River & $\mathrm{N}$ & $9 / 13 / 01$ & 0.269 & 0.04 & 0.00393 & \\
\hline Uranium-234 & 300 Area -5 HRM 43.1 & B158L8 & River & $\mathrm{N}$ & $9 / 10 / 02$ & 0.217 & 0.038 & 0.0181 & \\
\hline Uranium-234 & 300 Area -5 HRM 43.1 & B17CJ6 & River & $\mathrm{N}$ & 9/9/03 & 0.228 & 0.04 & 0.0127 & \\
\hline Uranium-234 & 300 Area -5 HRM 43.1 & B1B723 & River & $\mathrm{N}$ & $9 / 15 / 04$ & 0.223 & 0.048 & 0.0217 & \\
\hline Uranium-234 & 300 Area -4 HRM 43.1 & B0C5C0 & River & $\mathrm{N}$ & $8 / 26 / 94$ & 0.125 & 0.0675 & & \\
\hline Uranium-234 & 300 Area -4 HRM 43.1 & B0G896 & River & $\mathrm{N}$ & 9/18/95 & 0.211 & 0.0439 & & \\
\hline Uranium-234 & 300 Area -4 HRM 43.1 & B0J8X8 & River & $\mathrm{N}$ & $9 / 20 / 96$ & 0.317 & 0.0555 & & \\
\hline Uranium-234 & 300 Area -4 HRM 43.1 & BOLVW0 & River & $\mathrm{N}$ & $8 / 25 / 97$ & 0.234 & 0.0449 & & \\
\hline Uranium-234 & 300 Area -4 HRM 43.1 & B0PVP7 & River & $\mathrm{N}$ & 9/15/98 & 0.192 & 0.0448 & & \\
\hline Uranium-234 & 300 Area -3 HRM 43.1 & B0С5B9 & River & $\mathrm{N}$ & $8 / 26 / 94$ & 0.265 & 0.201 & & \\
\hline Uranium-234 & 300 Area -3 HRM 43.1 & B0G895 & River & $\mathrm{N}$ & 9/18/95 & 0.233 & 0.0456 & & \\
\hline Uranium-234 & 300 Area -3 HRM 43.1 & B0J8X6 & River & $\mathrm{N}$ & 9/20/96 & 0.212 & 0.0449 & & \\
\hline Uranium-234 & 300 Area -3 HRM 43.1 & B0LVV9 & River & $\mathrm{N}$ & $8 / 25 / 97$ & 0.248 & 0.047 & & \\
\hline Uranium-234 & 300 Area -3 HRM 43.1 & B0PVP6 & River & $\mathrm{N}$ & 9/15/98 & 0.178 & 0.0752 & & \\
\hline Uranium-234 & 300 Area -3 HRM 43.1 & B0WB25 & River & $\mathrm{N}$ & 9/16/99 & 0.197 & 0.036 & 0.012 & \\
\hline Uranium-234 & 300 Area -3 HRM 43.1 & B106X7 & River & $\mathrm{N}$ & $9 / 19 / 00$ & 0.196 & 0.031 & 0.00352 & \\
\hline Uranium-234 & 300 Area -3 HRM 43.1 & B12TC0 & River & $\mathrm{N}$ & $9 / 13 / 01$ & 0.24 & 0.037 & 0.0114 & \\
\hline Uranium-234 & 300 Area -3 HRM 43.1 & B158L7 & River & $\mathrm{N}$ & $9 / 10 / 02$ & 0.21 & 0.034 & 0.00917 & \\
\hline Uranium-234 & 300 Area -3 HRM 43.1 & B17CJ4 & River & $\mathrm{N}$ & $9 / 9 / 03$ & 0.254 & 0.041 & 0.0115 & \\
\hline Uranium-234 & 300 Area -3 HRM 43.1 & B1B722 & River & $\mathrm{N}$ & $9 / 15 / 04$ & 0.199 & 0.046 & 0.00683 & \\
\hline Uranium-234 & 300 Area -2 HRM 43.1 & B0C5B8 & River & $\mathrm{N}$ & $8 / 26 / 94$ & 0.112 & 0.0788 & & \\
\hline Uranium-234 & 300 Area -2 HRM 43.1 & B0G894 & River & $\mathrm{N}$ & 9/18/95 & 0.215 & 0.0521 & & \\
\hline Uranium-234 & 300 Area -2 HRM 43.1 & B0J8X4 & River & $\mathrm{N}$ & 9/20/96 & 0.325 & 0.0554 & & \\
\hline Uranium-234 & 300 Area -2 HRM 43.1 & B0LVV8 & River & $\mathrm{N}$ & $8 / 25 / 97$ & 0.245 & 0.0456 & & \\
\hline Uranium-234 & 300 Area -2 HRM 43.1 & B0PVP5 & River & $\mathrm{N}$ & 9/15/98 & 0.201 & 0.0509 & & \\
\hline Uranium-234 & 300 Area -2 HRM 43.1 & B0WB24 & River & $\mathrm{N}$ & $9 / 16 / 99$ & 0.182 & 0.037 & 0.0237 & \\
\hline Uranium-234 & 300 Area -2 HRM 43.1 & B106X5 & River & $\mathrm{N}$ & $9 / 19 / 00$ & 0.212 & 0.033 & 0.00364 & \\
\hline Uranium-234 & 300 Area -2 HRM 43.1 & B12TB8 & River & $\mathrm{N}$ & $9 / 13 / 01$ & 0.227 & 0.036 & 0.00932 & \\
\hline Uranium-234 & 300 Area -2 HRM 43.1 & B158L6 & River & $\mathrm{N}$ & $9 / 10 / 02$ & 0.223 & 0.035 & 0.0109 & \\
\hline Uranium-234 & 300 Area -2 HRM 43.1 & B17CJ2 & River & $\mathrm{N}$ & $9 / 9 / 03$ & 0.264 & 0.042 & 0.0148 & \\
\hline Uranium-234 & 300 Area -2 HRM 43.1 & B1B721 & River & $\mathrm{N}$ & $9 / 15 / 04$ & 0.172 & 0.04 & 0.00595 & \\
\hline Uranium-234 & 300 Area -1 HRM 43.1 & B0C5B7 & River & $\mathrm{N}$ & $8 / 26 / 94$ & 0.317 & 0.141 & & \\
\hline Uranium-234 & 300 Area -1 HRM 43.1 & B0G893 & River & $\mathrm{N}$ & 9/18/95 & 0.299 & 0.0513 & & \\
\hline Uranium-234 & 300 Area -1 HRM 43.1 & B0J8X2 & River & $\mathrm{N}$ & 9/20/96 & 0.591 & 0.0671 & & \\
\hline Uranium-234 & 300 Area -1 HRM 43.1 & B0LVV7 & River & $\mathrm{N}$ & $8 / 25 / 97$ & 0.244 & 0.0436 & & \\
\hline Uranium-234 & 300 Area -1 HRM 43.1 & B0PVP4 & River & $\mathrm{N}$ & 9/15/98 & 0.21 & 0.0466 & & \\
\hline Uranium-234 & 300 Area -1 HRM 43.1 & B0WB23 & River & $\mathrm{N}$ & 9/16/99 & 0.23 & 0.042 & 0.0172 & \\
\hline Uranium-234 & 300 Area -1 HRM 43.1 & B106X3 & River & $\mathrm{N}$ & $9 / 19 / 00$ & 0.174 & 0.028 & 0.00823 & \\
\hline Uranium-234 & 300 Area -1 HRM 43.1 & B12TB6 & River & $\mathrm{N}$ & $9 / 13 / 01$ & 0.215 & 0.034 & 0.00351 & \\
\hline Uranium-234 & 300 Area -1 HRM 43.1 & B158L5 & River & $\mathrm{N}$ & $9 / 10 / 02$ & 0.2 & 0.034 & 0.0105 & \\
\hline Uranium-234 & 300 Area -1 HRM 43.1 & B17CJ0 & River & $\mathrm{N}$ & 9 9/9/03 & 0.487 & 0.055 & 0.024 & \\
\hline Uranium-234 & 300 Area -1 HRM 43.1 & B1B720 & River & $\mathrm{N}$ & 9/15/04 & 0.256 & 0.055 & 0.00768 & \\
\hline Uranium-234 & 300 Area & B09QT2 & Drinking & $\mathrm{N}$ & $3 / 29 / 94$ & 0.382 & 0.0625 & & \\
\hline Uranium-234 & 300 Area & B0BP89 & Drinking & $\mathrm{N}$ & $6 / 21 / 94$ & 0.291 & 0.048 & & \\
\hline Uranium-234 & 300 Area & B0C477 & Drinking & $\mathrm{N}$ & $10 / 11 / 94$ & 0.544 & 0.0716 & & \\
\hline Uranium-234 & 300 Area & B0D0Y8 & Drinking & $\mathrm{N}$ & $1 / 3 / 95$ & 0.515 & 0.0772 & & \\
\hline Uranium-234 & 300 Area & B0DKB6 & Drinking & $\mathrm{N}$ & $3 / 27 / 95$ & 0.391 & 0.084 & & \\
\hline Uranium-234 & 300 Area & B0F909 & Drinking & $\mathrm{N}$ & 6/20/95 & 0.352 & 0.0544 & & \\
\hline
\end{tabular}


Table A.2. (contd)

\begin{tabular}{|c|c|c|c|c|c|c|c|c|c|}
\hline Analyte & Location & $\begin{array}{l}\text { Sample } \\
\text { Number }\end{array}$ & $\begin{array}{c}\text { Sampled } \\
\text { From }\end{array}$ & $\begin{array}{c}\text { Filter } \\
\text { Flag } \\
\end{array}$ & $\begin{array}{c}\text { Sample } \\
\text { Date }\end{array}$ & $\begin{array}{c}\text { Value } \\
\text { (pCi/L) }\end{array}$ & $\begin{array}{c}\text { Counting } \\
\text { Error } \\
\end{array}$ & MDA & $\begin{array}{l}\text { Quali- } \\
\text { fier }\end{array}$ \\
\hline Uranium-234 & 300 Area & B0G537 & Drinking & $\mathrm{N}$ & $10 / 10 / 95$ & 0.331 & 0.0573 & & \\
\hline Uranium-234 & 300 Area & B0GML6 & Drinking & $\mathrm{N}$ & $1 / 4 / 96$ & 0.322 & 0.0507 & & \\
\hline Uranium-234 & 300 Area & B0H524 & Drinking & $\mathrm{N}$ & 3/27/96 & 0.228 & 0.0448 & & \\
\hline Uranium-234 & 300 Area & B0HPT1 & Drinking & $\mathrm{N}$ & $6 / 19 / 96$ & 0.293 & 0.0537 & & \\
\hline Uranium-234 & 300 Area & B0J464 & Drinking & $\mathrm{N}$ & $10 / 9 / 96$ & 0.531 & 0.0724 & & \\
\hline Uranium-234 & 300 Area & B0JFJ4 & Drinking & $\mathrm{N}$ & $1 / 6 / 97$ & 0.493 & 0.131 & & \\
\hline Uranium-234 & 300 Area & B0JV31 & Drinking & $\mathrm{N}$ & $3 / 25 / 97$ & 0.706 & 0.112 & & \\
\hline Uranium-234 & 300 Area & B0K6X1 & Drinking & $\mathrm{N}$ & 7/17/97 & 0.38 & 0.0552 & & \\
\hline Uranium-234 & 300 Area & B0LHF7 & Drinking & $\mathrm{N}$ & $10 / 8 / 97$ & 0.676 & 0.0819 & & \\
\hline Uranium-234 & 300 Area & S0LWT9 & Drinking & $\mathrm{N}$ & $12 / 30 / 97$ & 0.81 & 0.0819 & & \\
\hline Uranium-234 & 300 Area & B0MTB2 & Drinking & $\mathrm{N}$ & $3 / 27 / 98$ & 0.847 & 0.0898 & & \\
\hline Uranium-234 & 300 Area & B0NHR3 & Drinking & $\mathrm{N}$ & $7 / 15 / 98$ & 0.323 & 0.0517 & & \\
\hline Uranium-234 & 300 Area & B0P8V0 & Drinking & $\mathrm{N}$ & $10 / 8 / 98$ & 1.33 & 0.11 & 0.0184 & \\
\hline Uranium-234 & 300 Area & B0R233 & Drinking & $\mathrm{N}$ & $12 / 30 / 98$ & 1.15 & 0.1 & 0.0158 & \\
\hline Uranium-234 & 300 Area & B19HD4 & River & $\mathrm{N}$ & $6 / 10 / 04$ & 0.235 & 0.046 & 0.0159 & \\
\hline Uranium-234 & 300 Area & B1BCB0 & River & $\mathrm{N}$ & $9 / 24 / 04$ & 0.179 & 0.036 & 0.0222 & \\
\hline
\end{tabular}

\section{A.1.3 Uranium-235 Surface Water Data}

There were 205 (169 nondetect) surface water samples of uranium-235 at the Richland Pumphouse location and 177 (116 nondetect) at the 300 Area location. The samples were collected between 1/25/1994 and 9/29/2005. The values are plotted in Figure A.3, and the data are presented in Table A.3.

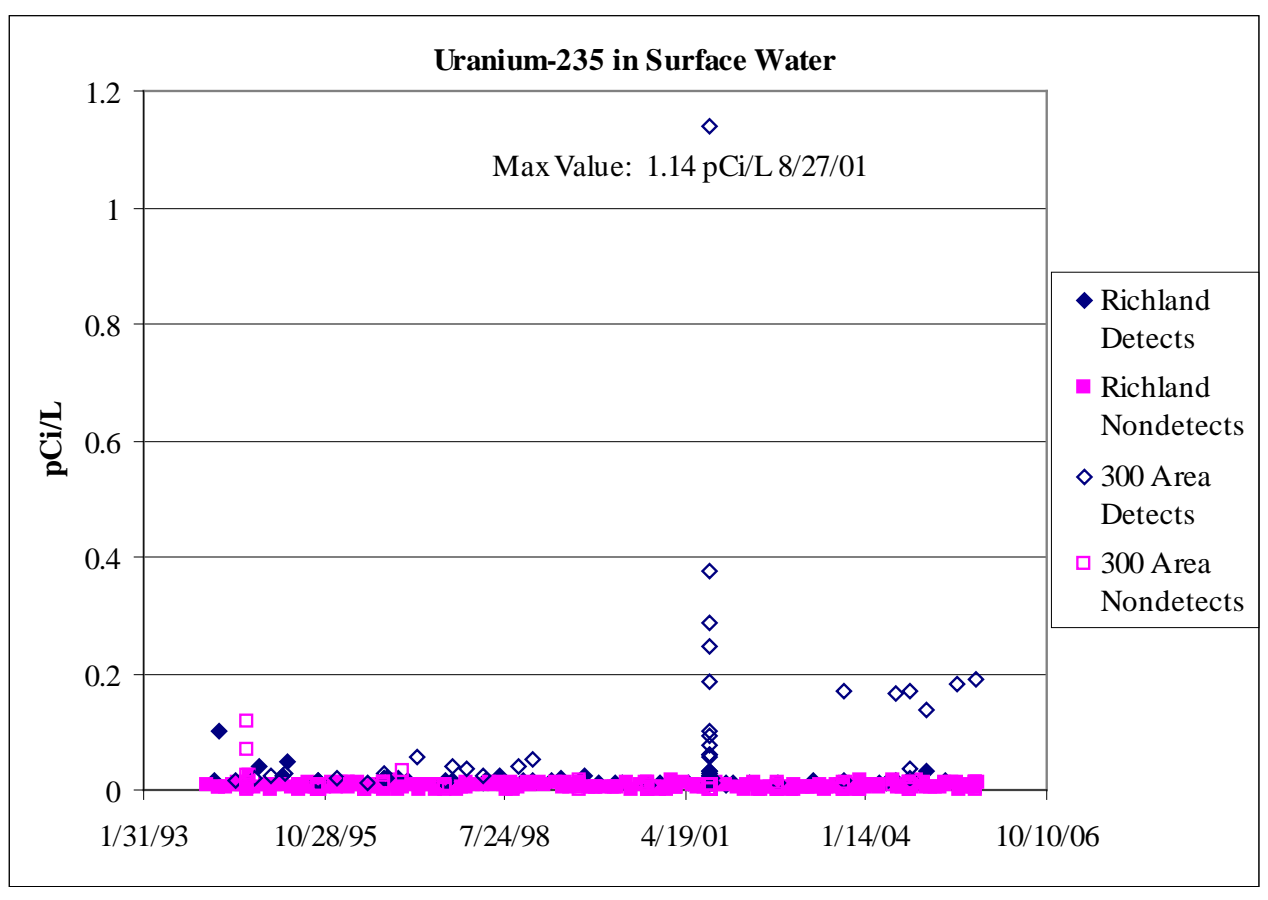

Figure A.3. Uranium-235 in Surface Water 
Table A.3. Uranium-235 Data in Surface Water

\begin{tabular}{|c|c|c|c|c|c|c|c|c|c|}
\hline Analyte & Location & $\begin{array}{l}\text { Sample } \\
\text { Number }\end{array}$ & $\begin{array}{c}\text { Sampled } \\
\text { From }\end{array}$ & $\begin{array}{c}\text { Filter } \\
\text { Flag }\end{array}$ & $\begin{array}{l}\text { Sample } \\
\text { Date } \\
\end{array}$ & $\begin{array}{c}\text { Value } \\
\text { (pCi/L) }\end{array}$ & $\begin{array}{c}\text { Counting } \\
\text { Error }\end{array}$ & MDA & $\begin{array}{l}\text { Quali- } \\
\text { fier } \\
\end{array}$ \\
\hline Uranium-235 & "Rich.Pmphs-1 HRM46.4 & & $\begin{array}{l}\text { River } \\
\end{array}$ & $\mathrm{NN}$ & $\begin{array}{ll}7 / 1 / 94 \\
\end{array}$ & 0.00804 & 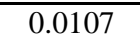 & & $\overline{\mathrm{U}}$ \\
\hline Uranium-235 & Rich.Pmphs-1 HRM46.4 & & River & $\mathrm{N}$ & $8 / 26 / 94$ & 0.00514 & 0.0561 & & $\mathrm{U}$ \\
\hline Uranium-235 & Rich.Pmphs-1 HRM46.4 & & River & $\mathrm{N}$ & $12 / 21 / 94$ & 0.00619 & 0.045 & & $\mathrm{U}$ \\
\hline Uranium-235 & Rich.Pmphs-1 HRM46.4 & & River & $\mathrm{N}$ & $3 / 17 / 95$ & 0.00627 & 0.00787 & & $\mathrm{U}$ \\
\hline Uranium-235 & Rich.Pmphs-1 HRM46.4 & & River & $\mathrm{N}$ & $6 / 16 / 95$ & 0.00899 & 0.0109 & & $\mathrm{U}$ \\
\hline Uranium-235 & Rich.Pmphs-1 HRM46.4 & & River & $\mathrm{N}$ & $9 / 18 / 95$ & 0.00664 & 0.00956 & & $\mathrm{U}$ \\
\hline Uranium-235 & Rich.Pmphs-1 HRM46.4 & & River & $\mathrm{N}$ & $12 / 7 / 95$ & 0.0084 & 0.0116 & & $\mathrm{U}$ \\
\hline Uranium-235 & Rich.Pmphs-1 HRM46.4 & & River & $\mathrm{N}$ & $3 / 18 / 96$ & 0.0118 & 0.0127 & & $\mathrm{U}$ \\
\hline Uranium-235 & Rich.Pmphs-1 HRM46.4 & & River & $\mathrm{N}$ & $3 / 18 / 96$ & 0.0112 & 0.0149 & & $\mathrm{U}$ \\
\hline Uranium-235 & Rich.Pmphs-1 HRM46.4 & & River & $\mathrm{N}$ & $6 / 7 / 96$ & 0.00142 & 0.00644 & & $\mathrm{U}$ \\
\hline Uranium-235 & Rich.Pmphs-1 HRM46.4 & & River & $\mathrm{N}$ & 9/20/96 & 0.000609 & 0.00558 & & $\mathrm{U}$ \\
\hline Uranium-235 & Rich.Pmphs-1 HRM46.4 & & River & $\mathrm{N}$ & $12 / 9 / 96$ & -0.000659 & 0.0068 & & $\mathrm{U}$ \\
\hline Uranium-235 & Rich.Pmphs-1 HRM46.4 & & River & $\mathrm{N}$ & $4 / 1 / 97$ & -0.000702 & 0.00516 & & $\mathrm{U}$ \\
\hline Uranium-235 & Rich.Pmphs-1 HRM46.4 & & River & $\mathrm{N}$ & 8/25/97 & 0.00394 & 0.008 & & $\mathrm{U}$ \\
\hline Uranium-235 & Rich.Pmphs-1 HRM46.4 & & River & $\mathrm{N}$ & $12 / 19 / 97$ & 0.00214 & 0.00603 & & U \\
\hline Uranium-235 & Rich.Pmphs-1 HRM46.4 & & River & $\mathrm{N}$ & $12 / 19 / 97$ & 0.00722 & 0.00927 & & $\mathrm{U}$ \\
\hline Uranium-235 & Rich.Pmphs-1 HRM46.4 & & River & $\mathrm{N}$ & $3 / 24 / 98$ & 0.00711 & 0.00806 & & $\mathrm{U}$ \\
\hline Uranium-235 & Rich.Pmphs-1 HRM46.4 & & River & $\mathrm{N}$ & $6 / 23 / 98$ & 0.0105 & 0.016 & & $\mathrm{U}$ \\
\hline Uranium-235 & Rich.Pmphs-1 HRM46.4 & & River & $\mathrm{N}$ & 9/15/98 & 0.00608 & 0.00833 & & $\mathrm{U}$ \\
\hline Uranium-235 & Rich.Pmphs-1 HRM46.4 & & River & $\mathrm{N}$ & $12 / 15 / 98$ & 0.00814 & 0.011 & 0.0179 & $\mathrm{U}$ \\
\hline Uranium-235 & Rich.Pmphs-1 HRM46.4 & & River & $\mathrm{N}$ & $12 / 15 / 98$ & 0.00845 & 0.011 & 0.0159 & $\mathrm{U}$ \\
\hline Uranium-235 & Rich.Pmphs-1 HRM46.4 & & River & $\mathrm{N}$ & 6/14/99 & 0.00794 & 0.0069 & 0.0125 & $\mathrm{U}$ \\
\hline Uranium-235 & Rich.Pmphs-1 HRM46.4 & & River & $\mathrm{N}$ & $6 / 14 / 99$ & 0.00221 & 0.0029 & 0.0119 & $\mathrm{U}$ \\
\hline Uranium-235 & Rich.Pmphs-1 HRM46.4 & & River & $\mathrm{N}$ & 9/16/99 & -0.00542 & 0.0031 & 0.0135 & $\mathrm{U}$ \\
\hline Uranium-235 & Rich.Pmphs-1 HRM46.4 & & River & $\mathrm{N}$ & $12 / 6 / 99$ & 0.00572 & 0.0057 & 0.0111 & $\bar{U}$ \\
\hline Uranium-235 & Rich.Pmphs-1 HRM46.4 & & River & $\mathrm{N}$ & $12 / 6 / 99$ & 0.00543 & 0.0069 & 0.0202 & $\bar{U}$ \\
\hline Uranium-235 & Rich.Pmphs-1 HRM46.4 & & River & $\mathrm{N}$ & $3 / 28 / 00$ & 0.00421 & 0.0042 & 0.00927 & $\bar{U}$ \\
\hline Uranium-235 & Rich.Pmphs-1 HRM46.4 & & River & $\mathrm{N}$ & $6 / 20 / 00$ & -0.00113 & 0.0029 & 0.0126 & $\mathrm{U}$ \\
\hline Uranium-235 & Rich.Pmphs-1 HRM46.4 & & River & $\mathrm{N}$ & 9/19/00 & 0.000331 & 0.00045 & 0.00798 & $\mathrm{U}$ \\
\hline Uranium-235 & Rich.Pmphs-1 HRM46.4 & & River & $\mathrm{N}$ & $12 / 5 / 00$ & 0.00199 & 0.006 & 0.00837 & $\mathrm{U}$ \\
\hline Uranium-235 & Rich.Pmphs-1 HRM46.4 & & River & $\mathrm{N}$ & $12 / 5 / 00$ & 0.00338 & 0.006 & 0.00364 & $\mathrm{U}$ \\
\hline Uranium-235 & Rich.Pmphs-1 HRM46.4 & & River & $\mathrm{N}$ & $2 / 26 / 01$ & 0.00542 & 0.0076 & 0.0097 & $\bar{U}$ \\
\hline Uranium-235 & Rich.Pmphs-1 HRM46.4 & & River & $\mathrm{N}$ & $2 / 26 / 01$ & 0.00542 & 0.0066 & 0.00339 & $\bar{U}$ \\
\hline Uranium-235 & Rich.Pmphs-1 HRM46.4 & & River & $\mathrm{N}$ & $6 / 12 / 01$ & 0.00833 & 0.0073 & 0.00923 & $\mathrm{U}$ \\
\hline Uranium-235 & Rich.Pmphs-1 HRM46.4 & & River & $\mathrm{N}$ & $9 / 13 / 01$ & 0.00759 & 0.0077 & 0.0037 & $\mathrm{U}$ \\
\hline Uranium-235 & Rich.Pmphs-1 HRM46.4 & & River & $\mathrm{N}$ & $12 / 4 / 01$ & 0.00698 & 0.0078 & 0.00399 & $\mathrm{U}$ \\
\hline Uranium-235 & Rich.Pmphs-1 HRM46.4 & & River & $\mathrm{N}$ & $3 / 26 / 02$ & 0.00687 & 0.0077 & 0.00395 & $\mathrm{U}$ \\
\hline Uranium-235 & Rich.Pmphs-1 HRM46.4 & & River & $\mathrm{N}$ & 6/11/02 & 0.000467 & 0.0044 & 0.00344 & $\mathrm{U}$ \\
\hline Uranium-235 & Rich.Pmphs-1 HRM46.4 & & River & $\mathrm{N}$ & 9/10/02 & 0.00475 & 0.0066 & 0.00366 & $\mathrm{U}$ \\
\hline Uranium-235 & Rich.Pmphs-1 HRM46.4 & & River & $\mathrm{N}$ & $12 / 10 / 02$ & -0.00117 & 0.0074 & 0.0157 & $\mathrm{U}$ \\
\hline Uranium-235 & Rich.Pmphs-1 HRM46.4 & & River & $\mathrm{N}$ & $12 / 10 / 02$ & 0.00689 & 0.0083 & 0.00462 & $\mathrm{U}$ \\
\hline Uranium-235 & Rich.Pmphs-1 HRM46.4 & & River & $\mathrm{N}$ & $3 / 25 / 03$ & 0.00452 & 0.0064 & 0.00352 & $\mathrm{U}$ \\
\hline Uranium-235 & Rich.Pmphs-1 HRM46.4 & & River & $\mathrm{N}$ & $3 / 25 / 03$ & 0.0058 & 0.0068 & 0.00351 & $\mathrm{U}$ \\
\hline Uranium-235 & Rich.Pmphs-1 HRM46.4 & & River & $\mathrm{N}$ & $6 / 10 / 03$ & 0.00554 & 0.011 & 0.0163 & $\mathrm{U}$ \\
\hline Uranium-235 & Rich.Pmphs-1 HRM46.4 & & River & $\mathrm{N}$ & 9/9/03 & 0.00623 & 0.0099 & 0.0147 & $\mathrm{U}$ \\
\hline Uranium-235 & Rich.Pmphs-1 HRM46.4 & & River & $\mathrm{N}$ & $12 / 8 / 03$ & 0.0153 & 0.015 & 0.0193 & $\mathrm{U}$ \\
\hline Uranium-235 & Rich.Pmphs-1 HRM46.4 & & River & $\mathrm{N}$ & $12 / 8 / 03$ & -0.000594 & 0.015 & 0.0296 & $\overline{\mathrm{U}}$ \\
\hline Uranium-235 & Rich.Pmphs-1 HRM46.4 & & River & $\mathrm{N}$ & $3 / 30 / 04$ & 0.00411 & 0.0089 & 0.0137 & $\mathrm{U}$ \\
\hline Uranium-235 & Rich.Pmphs-1 HRM46.4 & & River & $\mathrm{N}$ & 9/15/04 & 0.00374 & 0.0065 & 0.00622 & $\mathrm{U}$ \\
\hline
\end{tabular}


Table A.3. (contd)

\begin{tabular}{|c|c|c|c|c|c|c|c|c|c|}
\hline Analyte & Location & $\begin{array}{l}\text { Sample } \\
\text { Number }\end{array}$ & $\begin{array}{c}\text { Sampled } \\
\text { From }\end{array}$ & $\begin{array}{c}\overline{\text { Filter }} \\
\text { Flag }\end{array}$ & $\begin{array}{l}\text { Sample } \\
\text { Date }\end{array}$ & $\begin{array}{l}\text { Value } \\
\text { (pCi/L) }\end{array}$ & $\begin{array}{c}\text { Counting } \\
\text { Error }\end{array}$ & MDA & $\begin{array}{l}\text { Quali- } \\
\text { fier }\end{array}$ \\
\hline Uranium-235 & Rich.Pmphs-1 HRM46.4 & & River & 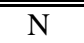 & 12/19/04 & 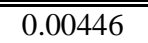 & ( 0.0065 & 年 0.00977 & 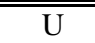 \\
\hline Uranium-235 & Rich.Pmphs-1 HRM46.4 & & River & $\mathrm{N}$ & $3 / 29 / 05$ & 0.00805 & 0.0076 & 0.00936 & $\mathrm{U}$ \\
\hline Uranium-235 & Rich.Pmphs-1 HRM46.4 & & River & $\mathrm{N}$ & $6 / 7 / 05$ & 0.0102 & 0.0074 & 0.00334 & $\mathrm{U}$ \\
\hline Uranium-235 & Rich.Pmphs-1 HRM46.4 & & River & $\mathrm{N}$ & $9 / 14 / 05$ & 0.0117 & 0.0084 & 0.00378 & $\mathrm{U}$ \\
\hline Uranium-235 & Rich.Pmphs HRM 46.4 & & River & $\mathrm{N}$ & $1 / 25 / 94$ & 0.00771 & 0.0111 & & $\mathrm{U}$ \\
\hline Uranium-235 & Rich.Pmphs HRM 46.4 & & River & $\mathrm{N}$ & $3 / 29 / 94$ & 0.00456 & 0.011 & & $\mathrm{U}$ \\
\hline Uranium-235 & Rich.Pmphs HRM 46.4 & & River & $\mathrm{N}$ & $5 / 3 / 94$ & 0.00349 & 0.00859 & & $\bar{U}$ \\
\hline Uranium-235 & Rich.Pmphs HRM 46.4 & & River & $\mathrm{N}$ & $6 / 7 / 94$ & 0.0101 & 0.0117 & & $\mathrm{U}$ \\
\hline Uranium-235 & Rich.Pmphs HRM 46.4 & & River & $\mathrm{N}$ & $7 / 6 / 94$ & 0.0104 & 0.0113 & & $\mathrm{U}$ \\
\hline Uranium-235 & Rich.Pmphs HRM 46.4 & & River & $\mathrm{N}$ & $8 / 1 / 94$ & 0.00835 & 0.00914 & & $\mathrm{U}$ \\
\hline Uranium-235 & Rich.Pmphs HRM 46.4 & & River & $\mathrm{N}$ & $9 / 6 / 94$ & 0.0248 & 0.0314 & & $\mathrm{U}$ \\
\hline Uranium-235 & Rich.Pmphs HRM 46.4 & & River & $\mathrm{N}$ & $10 / 4 / 94$ & 0.00432 & 0.00724 & & $\bar{U}$ \\
\hline Uranium-235 & Rich.Pmphs HRM 46.4 & & River & $\mathrm{N}$ & $12 / 6 / 94$ & 0.00978 & 0.0135 & & $\mathrm{U}$ \\
\hline Uranium-235 & Rich.Pmphs HRM 46.4 & & River & $\mathrm{N}$ & $1 / 3 / 95$ & $8.26 \mathrm{E}-06$ & $9.13 \mathrm{E}-06$ & & $\bar{U}$ \\
\hline Uranium-235 & Rich.Pmphs HRM 46.4 & & River & $\mathrm{N}$ & $2 / 7 / 95$ & 0.00676 & 0.0108 & & $\bar{U}$ \\
\hline Uranium-235 & Rich.Pmphs HRM 46.4 & & River & $\mathrm{N}$ & $5 / 2 / 95$ & 0.00292 & 0.00675 & & $\bar{U}$ \\
\hline Uranium-235 & Rich.Pmphs HRM 46.4 & & River & $\mathrm{N}$ & $6 / 6 / 95$ & -0.000244 & 0.00679 & & $\bar{U}$ \\
\hline Uranium-235 & Rich.Pmphs HRM 46.4 & & River & $\mathrm{N}$ & $7 / 5 / 95$ & 0.00477 & 0.0116 & & $\mathrm{U}$ \\
\hline Uranium-235 & Rich.Pmphs HRM 46.4 & & River & $\mathrm{N}$ & $8 / 1 / 95$ & 0.0107 & 0.0117 & & $\mathrm{U}$ \\
\hline Uranium-235 & Rich.Pmphs HRM 46.4 & & River & $\mathrm{N}$ & 9/6/95 & 0.00408 & 0.00912 & & $\mathrm{U}$ \\
\hline Uranium-235 & Rich.Pmphs HRM 46.4 & & River & $\mathrm{N}$ & $10 / 3 / 95$ & -0.000739 & 0.0112 & & $\mathrm{U}$ \\
\hline Uranium-235 & Rich.Pmphs HRM 46.4 & & River & $\mathrm{N}$ & $11 / 8 / 95$ & 0.00382 & 0.00763 & & $\mathrm{U}$ \\
\hline Uranium-235 & Rich.Pmphs HRM 46.4 & & River & $\mathrm{N}$ & $12 / 5 / 95$ & 0.0102 & 0.0106 & & $\bar{U}$ \\
\hline Uranium-235 & Rich.Pmphs HRM 46.4 & & River & $\mathrm{N}$ & $1 / 3 / 96$ & 0.00346 & 0.00883 & & $\bar{U}$ \\
\hline Uranium-235 & Rich.Pmphs HRM 46.4 & & River & $\mathrm{N}$ & $2 / 7 / 96$ & 0.0127 & 0.0129 & & $\bar{U}$ \\
\hline Uranium-235 & Rich.Pmphs HRM 46.4 & & River & $\mathrm{N}$ & $3 / 6 / 96$ & 0.00385 & 0.01 & & $\mathrm{U}$ \\
\hline Uranium-235 & Rich.Pmphs HRM 46.4 & & River & $\mathrm{N}$ & $4 / 3 / 96$ & 0.01 & 0.012 & & $\mathrm{U}$ \\
\hline Uranium-235 & Rich.Pmphs HRM 46.4 & & River & $\mathrm{N}$ & $5 / 8 / 96$ & 0.0106 & 0.0119 & & $\mathrm{U}$ \\
\hline Uranium-235 & Rich.Pmphs HRM 46.4 & & River & $\mathrm{N}$ & $6 / 5 / 96$ & 0.00143 & 0.00652 & & $\mathrm{U}$ \\
\hline Uranium-235 & Rich.Pmphs HRM 46.4 & & River & $\mathrm{N}$ & $7 / 2 / 96$ & 0.00279 & 0.00927 & & $\mathrm{U}$ \\
\hline Uranium-235 & Rich.Pmphs HRM 46.4 & & River & $\mathrm{N}$ & $8 / 7 / 96$ & 0.0068 & 0.00828 & & $\mathrm{U}$ \\
\hline Uranium-235 & Rich.Pmphs HRM 46.4 & & River & $\mathrm{N}$ & $9 / 4 / 96$ & 0.00521 & 0.00936 & & $\mathrm{U}$ \\
\hline Uranium-235 & Rich.Pmphs HRM 46.4 & & River & $\mathrm{N}$ & $10 / 9 / 96$ & 0.0084 & 0.0105 & & $\mathrm{U}$ \\
\hline Uranium-235 & Rich.Pmphs HRM 46.4 & & River & $\mathrm{N}$ & $11 / 6 / 96$ & 0.0146 & 0.0233 & & $\mathrm{U}$ \\
\hline Uranium-235 & Rich.Pmphs HRM 46.4 & & River & $\mathrm{N}$ & $12 / 30 / 96$ & 0.00288 & 0.00987 & & $\mathrm{U}$ \\
\hline Uranium-235 & Rich.Pmphs HRM 46.4 & & River & $\mathrm{N}$ & $3 / 5 / 97$ & 0.00806 & 0.00928 & & $\mathrm{U}$ \\
\hline Uranium-235 & Rich.Pmphs HRM 46.4 & & River & $\mathrm{N}$ & $4 / 9 / 97$ & 0.00685 & 0.0102 & & $\mathrm{U}$ \\
\hline Uranium-235 & Rich.Pmphs HRM 46.4 & & River & $\mathrm{N}$ & $5 / 7 / 97$ & 0.00903 & 0.0132 & & $\overline{\mathrm{U}}$ \\
\hline Uranium-235 & Rich.Pmphs HRM 46.4 & & River & $\mathrm{N}$ & $6 / 4 / 97$ & 0.00938 & 0.0103 & & $\bar{U}$ \\
\hline Uranium-235 & Rich.Pmphs HRM 46.4 & & River & $\mathrm{N}$ & $7 / 9 / 97$ & 0.00152 & 0.00897 & & $\bar{U}$ \\
\hline Uranium-235 & Rich.Pmphs HRM 46.4 & & River & $\mathrm{N}$ & $8 / 6 / 97$ & 0.0099 & 0.00987 & & $\mathrm{U}$ \\
\hline Uranium-235 & Rich.Pmphs HRM 46.4 & & River & $\mathrm{N}$ & $11 / 5 / 97$ & -0.000591 & 0.0221 & & $\mathrm{U}$ \\
\hline Uranium-235 & Rich.Pmphs HRM 46.4 & & River & $\mathrm{N}$ & $12 / 3 / 97$ & 0.00346 & 0.0077 & & $\mathrm{U}$ \\
\hline Uranium-235 & Rich.Pmphs HRM 46.4 & & River & $\mathrm{N}$ & $12 / 30 / 97$ & 0.0125 & 0.0133 & & $\mathrm{U}$ \\
\hline Uranium-235 & Rich.Pmphs HRM 46.4 & & River & $\mathrm{N}$ & $2 / 4 / 98$ & 0.00815 & 0.00925 & & $\mathrm{U}$ \\
\hline Uranium-235 & Rich.Pmphs HRM 46.4 & & River & $\mathrm{N}$ & $3 / 4 / 98$ & -0.00679 & 0.0173 & & $\mathrm{U}$ \\
\hline Uranium-235 & Rich.Pmphs HRM 46.4 & & River & $\mathrm{N}$ & $5 / 7 / 98$ & 0.0115 & 0.0133 & & $\mathrm{U}$ \\
\hline Uranium-235 & Rich.Pmphs HRM 46.4 & & River & $\mathrm{N}$ & $6 / 4 / 98$ & 0.00994 & 0.0148 & & $\mathrm{U}$ \\
\hline Uranium-235 & Rich.Pmphs HRM 46.4 & & River & $\mathrm{N}$ & $7 / 29 / 98$ & 0.000704 & 0.0113 & & $\mathrm{U}$ \\
\hline
\end{tabular}


Table A.3. (contd)

\begin{tabular}{|c|c|c|c|c|c|c|c|c|c|}
\hline Analyte & Location & $\begin{array}{l}\text { Sample } \\
\text { Number }\end{array}$ & $\begin{array}{c}\text { Sampled } \\
\text { From }\end{array}$ & $\begin{array}{c}\text { Filter } \\
\text { Flag }\end{array}$ & $\begin{array}{l}\text { Sample } \\
\text { Date } \\
\end{array}$ & $\begin{array}{c}\text { Value } \\
\text { (pCi/L) }\end{array}$ & $\begin{array}{c}\text { Counting } \\
\text { Error }\end{array}$ & MDA & $\begin{array}{l}\text { Quali- } \\
\text { fier } \\
\end{array}$ \\
\hline Uranium-235 & "Rich.Pmphs HRM 46.4 & & $\begin{array}{l}\text { River } \\
\end{array}$ & $\overline{\mathrm{N}}$ & $\begin{array}{l}9 / 2 / 98 \\
\end{array}$ & 0.0115 & 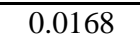 & & $\bar{U}$ \\
\hline Uranium-235 & Rich.Pmphs HRM 46.4 & & $\begin{array}{l}\text { River } \\
\end{array}$ & $\mathrm{N}$ & 10/8/98 & 0.00222 & 0.0089 & 0.0172 & $\bar{U}$ \\
\hline Uranium-235 & Rich.Pmphs HRM 46.4 & & $\begin{array}{l}\text { River } \\
\end{array}$ & $\mathrm{N}$ & $12 / 3 / 98$ & 0.0102 & 0.012 & 0.0191 & $\mathrm{U}$ \\
\hline Uranium-235 & Rich.Pmphs HRM 46.4 & & River & $\mathrm{N}$ & $2 / 3 / 99$ & 0.0123 & 0.011 & 0.0143 & $\mathrm{U}$ \\
\hline Uranium-235 & Rich.Pmphs HRM 46.4 & & River & $\mathrm{N}$ & $3 / 3 / 99$ & 0.00858 & 0.0095 & 0.0113 & $\mathrm{U}$ \\
\hline Uranium-235 & Rich.Pmphs HRM 46.4 & & River & $\mathrm{N}$ & $5 / 5 / 99$ & 0.0133 & 0.01 & 0.0133 & $\mathrm{U}$ \\
\hline Uranium-235 & Rich.Pmphs HRM 46.4 & & River & $\mathrm{N}$ & $6 / 30 / 99$ & 0.0115 & 0.0095 & 0.0185 & $\mathrm{U}$ \\
\hline Uranium-235 & Rich.Pmphs HRM 46.4 & & River & $\mathrm{N}$ & $7 / 28 / 99$ & 0.00357 & 0.0039 & 0.0113 & $\mathrm{U}$ \\
\hline Uranium-235 & Rich.Pmphs HRM 46.4 & & River & $\mathrm{N}$ & $9 / 1 / 99$ & 0.0081 & 0.0066 & 0.0098 & $\mathrm{U}$ \\
\hline Uranium-235 & Rich.Pmphs HRM 46.4 & & River & $\mathrm{N}$ & $11 / 3 / 99$ & 0.00436 & 0.0046 & 0.0125 & $\mathrm{U}$ \\
\hline Uranium-235 & Rich.Pmphs HRM 46.4 & & River & $\mathrm{N}$ & $12 / 1 / 99$ & 0.00552 & 0.0045 & 0.004 & $\mathrm{U}$ \\
\hline Uranium-235 & Rich.Pmphs HRM 46.4 & & River & $\mathrm{N}$ & $2 / 2 / 00$ & 0.00296 & 0.0029 & 0.00774 & $\mathrm{U}$ \\
\hline Uranium-235 & Rich.Pmphs HRM 46.4 & & River & $\mathrm{N}$ & $3 / 8 / 00$ & 0.00254 & 0.0046 & 0.0211 & $\mathrm{U}$ \\
\hline Uranium-235 & Rich.Pmphs HRM 46.4 & & River & $\mathrm{N}$ & $4 / 5 / 00$ & 0.00317 & 0.0039 & 0.0134 & $\mathrm{U}$ \\
\hline Uranium-235 & Rich.Pmphs HRM 46.4 & & River & $\mathrm{N}$ & $5 / 31 / 00$ & 0.0129 & 0.01 & 0.0195 & $\mathrm{U}$ \\
\hline Uranium-235 & Rich.Pmphs HRM 46.4 & & River & $\mathrm{N}$ & $6 / 29 / 00$ & -0.00209 & 0.0049 & 0.0118 & $\mathrm{U}$ \\
\hline Uranium-235 & Rich.Pmphs HRM 46.4 & & River & $\mathrm{N}$ & $8 / 10 / 00$ & 0.00897 & 0.0087 & 0.0163 & $\mathrm{U}$ \\
\hline Uranium-235 & Rich.Pmphs HRM 46.4 & & River & $\mathrm{N}$ & $9 / 7 / 00$ & 0.011 & 0.0088 & 0.0136 & $\mathrm{U}$ \\
\hline Uranium-235 & Rich.Pmphs HRM 46.4 & & River & $\mathrm{N}$ & $10 / 5 / 00$ & 0.00215 & 0.0024 & 0.00899 & $\mathrm{U}$ \\
\hline Uranium-235 & Rich.Pmphs HRM 46.4 & & River & $\mathrm{N}$ & $11 / 2 / 00$ & 0.00567 & 0.0043 & 0.00348 & $\mathrm{U}$ \\
\hline Uranium-235 & Rich.Pmphs HRM 46.4 & & River & $\mathrm{N}$ & $1 / 4 / 01$ & -0.000368 & 0.0041 & 0.00646 & $\mathrm{U}$ \\
\hline Uranium-235 & Rich.Pmphs HRM 46.4 & & River & $\mathrm{N}$ & $1 / 31 / 01$ & 0.0157 & 0.021 & 0.0354 & $\mathrm{U}$ \\
\hline Uranium-235 & Rich.Pmphs HRM 46.4 & & River & $\mathrm{N}$ & $3 / 1 / 01$ & 0.00513 & 0.0087 & 0.0135 & $\bar{U}$ \\
\hline Uranium-235 & Rich.Pmphs HRM 46.4 & & River & $\mathrm{N}$ & $4 / 4 / 01$ & 0.0124 & 0.013 & 0.0182 & $\mathrm{U}$ \\
\hline Uranium-235 & Rich.Pmphs HRM 46.4 & & River & $\mathrm{N}$ & $5 / 30 / 01$ & 0.00638 & 0.0062 & 0.00842 & $\mathrm{U}$ \\
\hline Uranium-235 & Rich.Pmphs HRM 46.4 & & River & $\mathrm{N}$ & $6 / 28 / 01$ & 0.0039 & 0.0072 & 0.00491 & $\mathrm{U}$ \\
\hline Uranium-235 & Rich.Pmphs HRM 46.4 & & River & $\mathrm{N}$ & $8 / 9 / 01$ & 0.00501 & 0.0089 & 0.0136 & $\mathrm{U}$ \\
\hline Uranium-235 & Rich.Pmphs HRM 46.4 & & River & $\mathrm{N}$ & $9 / 5 / 01$ & 0.00776 & 0.009 & 0.00497 & $\mathrm{U}$ \\
\hline Uranium-235 & Rich.Pmphs HRM 46.4 & & River & $\mathrm{N}$ & $10 / 2 / 01$ & 0.0113 & 0.011 & 0.00568 & $\mathrm{U}$ \\
\hline Uranium-235 & Rich.Pmphs HRM 46.4 & & River & $\mathrm{N}$ & 11/1/01 & 0.00873 & 0.0084 & 0.00901 & $\mathrm{U}$ \\
\hline Uranium-235 & Rich.Pmphs HRM 46.4 & & River & $\mathrm{N}$ & $2 / 6 / 02$ & 0.00442 & 0.0063 & 0.0035 & $\bar{U}$ \\
\hline Uranium-235 & Rich.Pmphs HRM 46.4 & & River & $\mathrm{N}$ & $3 / 7 / 02$ & 0.00183 & 0.006 & 0.00467 & $\mathrm{U}$ \\
\hline Uranium-235 & Rich.Pmphs HRM 46.4 & & River & $\mathrm{N}$ & $5 / 1 / 02$ & 0.0121 & 0.014 & 0.0154 & $\mathrm{U}$ \\
\hline Uranium-235 & Rich.Pmphs HRM 46.4 & & River & $\mathrm{N}$ & $5 / 29 / 02$ & 0.0017 & 0.005 & 0.00341 & $\mathrm{U}$ \\
\hline Uranium-235 & Rich.Pmphs HRM 46.4 & & River & $\mathrm{N}$ & $6 / 27 / 02$ & 0.00205 & 0.008 & 0.0131 & $\mathrm{U}$ \\
\hline Uranium-235 & Rich.Pmphs HRM 46.4 & & River & $\mathrm{N}$ & $8 / 7 / 02$ & 0.00251 & 0.0064 & 0.00957 & $\mathrm{U}$ \\
\hline Uranium-235 & Rich.Pmphs HRM 46.4 & & River & $\mathrm{N}$ & $10 / 2 / 02$ & 0.00411 & 0.0047 & 0.00371 & $\mathrm{U}$ \\
\hline Uranium-235 & Rich.Pmphs HRM 46.4 & & River & $\mathrm{N}$ & $10 / 30 / 02$ & 0.00419 & 0.0067 & 0.00408 & $\bar{U}$ \\
\hline Uranium-235 & Rich.Pmphs HRM 46.4 & & River & $\mathrm{N}$ & $11 / 26 / 02$ & 0.00182 & 0.0051 & 0.00346 & $\mathrm{U}$ \\
\hline Uranium-235 & Rich.Pmphs HRM 46.4 & & River & $\mathrm{N}$ & $1 / 8 / 03$ & 0.00597 & 0.007 & 0.0036 & $\bar{U}$ \\
\hline Uranium-235 & Rich.Pmphs HRM 46.4 & & River & $\mathrm{N}$ & $2 / 5 / 03$ & 0.00576 & 0.0067 & 0.00345 & $\mathrm{U}$ \\
\hline Uranium-235 & Rich.Pmphs HRM 46.4 & & River & $\mathrm{N}$ & $3 / 5 / 03$ & 0.00208 & 0.0053 & 0.00357 & $\mathrm{U}$ \\
\hline Uranium-235 & Rich.Pmphs HRM 46.4 & & River & $\mathrm{N}$ & $4 / 30 / 03$ & 0.00844 & 0.0097 & 0.0151 & $\mathrm{U}$ \\
\hline Uranium-235 & Rich.Pmphs HRM 46.4 & & River & $\mathrm{N}$ & $5 / 28 / 03$ & 0.000688 & 0.008 & 0.0148 & $\mathrm{U}$ \\
\hline Uranium-235 & Rich.Pmphs HRM 46.4 & & River & $\mathrm{N}$ & $7 / 10 / 03$ & 0.00319 & 0.0064 & 0.00798 & $\bar{U}$ \\
\hline Uranium-235 & Rich.Pmphs HRM 46.4 & & River & $\mathrm{N}$ & $8 / 8 / 03$ & 0.0101 & 0.01 & 0.01 & $\mathrm{U}$ \\
\hline Uranium-235 & Rich.Pmphs HRM 46.4 & & River & $\mathrm{N}$ & $9 / 3 / 03$ & 0.00905 & 0.0091 & 0.00613 & $\mathrm{U}$ \\
\hline Uranium-235 & Rich.Pmphs HRM 46.4 & & River & $\mathrm{N}$ & $9 / 30 / 03$ & 0.0105 & 0.012 & 0.0165 & $\bar{U}$ \\
\hline Uranium-235 & Rich.Pmphs HRM 46.4 & & River & $\mathrm{N}$ & $10 / 29 / 03$ & 0.00628 & 0.0096 & 0.00649 & $\mathrm{U}$ \\
\hline
\end{tabular}


Table A.3. (contd)

\begin{tabular}{|c|c|c|c|c|c|c|c|c|c|}
\hline Analyte & Location & $\begin{array}{l}\text { Sample } \\
\text { Number }\end{array}$ & $\begin{array}{c}\text { Sampled } \\
\text { From }\end{array}$ & $\begin{array}{l}\text { Filter } \\
\text { Flag }\end{array}$ & $\begin{array}{l}\text { Sample } \\
\text { Date }\end{array}$ & $\begin{array}{l}\text { Value } \\
\text { (pCi/L) }\end{array}$ & $\begin{array}{c}\text { Counting } \\
\text { Error }\end{array}$ & MDA & $\begin{array}{l}\text { Quali- } \\
\text { fier }\end{array}$ \\
\hline Uranium-235 & "Rich.Pmphs HRM 46.4 & & River & $\mathrm{N}$ & $111 / 25 / 03$ & 0.00125 & 0.0053 & 0.00415 & $\mathrm{U}$ \\
\hline Uranium-235 & Rich.Pmphs HRM 46.4 & & River & $\mathrm{N}$ & $1 / 8 / 04$ & 0.00594 & 0.0092 & 0.00623 & $\mathrm{U}$ \\
\hline Uranium-235 & Rich.Pmphs HRM 46.4 & & $\begin{array}{l}\text { River } \\
\end{array}$ & $\mathrm{N}$ & $2 / 4 / 04$ & 0.00854 & 0.009 & 0.0046 & $\mathrm{U}$ \\
\hline Uranium-235 & Rich.Pmphs HRM 46.4 & & River & $\mathrm{N}$ & $3 / 2 / 04$ & 0.0085 & 0.0075 & 0.00858 & $\mathrm{U}$ \\
\hline Uranium-235 & Rich.Pmphs HRM 46.4 & & River & $\mathrm{N}$ & $4 / 1 / 04$ & 0.00818 & 0.012 & 0.0201 & $\mathrm{U}$ \\
\hline Uranium-235 & Rich.Pmphs HRM 46.4 & & River & $\mathrm{N}$ & $6 / 8 / 04$ & 0.0176 & 0.018 & 0.022 & $\mathrm{U}$ \\
\hline Uranium-235 & Rich.Pmphs HRM 46.4 & & River & $\mathrm{N}$ & $7 / 8 / 04$ & 0.00329 & 0.0086 & 0.0142 & $\mathrm{U}$ \\
\hline Uranium-235 & Rich.Pmphs HRM 46.4 & & River & $\mathrm{N}$ & $8 / 4 / 04$ & 0.00499 & 0.0074 & 0.00451 & $\mathrm{U}$ \\
\hline Uranium-235 & Rich.Pmphs HRM 46.4 & & River & $\mathrm{N}$ & $8 / 31 / 04$ & 0.00608 & 0.0069 & 0.0047 & $\overline{\mathrm{U}}$ \\
\hline Uranium-235 & Rich.Pmphs HRM 46.4 & & River & $\mathrm{N}$ & $10 / 1 / 04$ & 0.00605 & 0.0073 & 0.0112 & $\overline{\mathrm{U}}$ \\
\hline Uranium-235 & Rich.Pmphs HRM 46.4 & & River & $\mathrm{N}$ & $10 / 28 / 04$ & 0.0144 & 0.014 & 0.00827 & $\bar{U}$ \\
\hline Uranium-235 & Rich.Pmphs HRM 46.4 & & River & $\mathrm{N}$ & $12 / 1 / 04$ & 0.0113 & 0.0097 & 0.0125 & $\mathrm{U}$ \\
\hline Uranium-235 & Rich.Pmphs HRM 46.4 & & River & $\mathrm{N}$ & $1 / 5 / 05$ & 0.00453 & 0.0054 & 0.00364 & $\mathrm{U}$ \\
\hline Uranium-235 & Rich.Pmphs HRM 46.4 & & River & $\mathrm{N}$ & $2 / 3 / 05$ & 0.00423 & 0.0059 & 0.00459 & $\overline{\mathrm{U}}$ \\
\hline Uranium-235 & Rich.Pmphs HRM 46.4 & & River & $\mathrm{N}$ & $3 / 2 / 05$ & 0.00564 & 0.0065 & 0.00439 & $\mathrm{U}$ \\
\hline Uranium-235 & Rich.Pmphs HRM 46.4 & & River & $\mathrm{N}$ & $3 / 31 / 05$ & 0.0111 & 0.009 & 0.00462 & $\overline{\mathrm{U}}$ \\
\hline Uranium-235 & Rich.Pmphs HRM 46.4 & & River & $\mathrm{N}$ & $5 / 3 / 05$ & 0.0137 & 0.0097 & 0.00438 & $\overline{\mathrm{U}}$ \\
\hline Uranium-235 & Rich.Pmphs HRM 46.4 & & River & $\mathrm{N}$ & $6 / 9 / 05$ & 0.000519 & 0.0027 & 0.00368 & $\overline{\mathrm{U}}$ \\
\hline Uranium-235 & Rich.Pmphs HRM 46.4 & & River & $\mathrm{N}$ & $7 / 7 / 05$ & 0.00797 & 0.0067 & 0.00341 & $\overline{\mathrm{U}}$ \\
\hline Uranium-235 & Rich.Pmphs HRM 46.4 & & River & $\mathrm{N}$ & $8 / 4 / 05$ & 0.00532 & 0.0061 & 0.00753 & $\mathrm{U}$ \\
\hline Uranium-235 & Rich.Pmphs HRM 46.4 & & River & $\mathrm{N}$ & $8 / 31 / 05$ & 0.00479 & 0.0069 & 0.0104 & $\bar{U}$ \\
\hline Uranium-235 & Rich.Pmphs HRM 46.4 & & River & $\mathrm{N}$ & $9 / 29 / 05$ & 0.0102 & 0.0083 & 0.00425 & $\mathrm{U}$ \\
\hline Uranium-235 & Rich.Pmphs-1 HRM46.4 & & River & $\mathrm{N}$ & $3 / 28 / 00$ & 0.0124 & 0.0087 & 0.0117 & $\mathrm{~J}$ \\
\hline Uranium-235 & Rich.Pmphs HRM 46.4 & & River & $\mathrm{N}$ & $10 / 28 / 98$ & 0.0168 & 0.012 & 0.0114 & $\mathrm{~J}$ \\
\hline Uranium-235 & Rich.Pmphs HRM 46.4 & & River & $\mathrm{N}$ & $12 / 30 / 98$ & 0.0143 & 0.012 & 0.0104 & $\mathrm{~J}$ \\
\hline Uranium-235 & Rich.Pmphs HRM 46.4 & & River & $\mathrm{N}$ & $4 / 7 / 99$ & 0.0146 & 0.011 & 0.00958 & $\mathrm{~J}$ \\
\hline Uranium-235 & Rich.Pmphs HRM 46.4 & & River & $\mathrm{N}$ & $6 / 2 / 99$ & 0.0191 & 0.011 & 0.00934 & $\bar{J}$ \\
\hline Uranium-235 & Rich.Pmphs HRM 46.4 & & River & $\mathrm{N}$ & $10 / 6 / 99$ & 0.0227 & 0.013 & 0.018 & $\mathrm{~J}$ \\
\hline Uranium-235 & Rich.Pmphs HRM 46.4 & & River & $\mathrm{N}$ & $12 / 29 / 99$ & 0.0128 & 0.0085 & 0.00951 & $\mathrm{~J}$ \\
\hline Uranium-235 & Rich.Pmphs HRM 46.4 & & River & $\mathrm{N}$ & $5 / 3 / 00$ & 0.0135 & 0.0089 & 0.00989 & $\mathrm{~J}$ \\
\hline Uranium-235 & Rich.Pmphs HRM 46.4 & & River & $\mathrm{N}$ & $11 / 29 / 00$ & 0.0135 & 0.013 & 0.00652 & $\mathrm{~J}$ \\
\hline Uranium-235 & Rich.Pmphs-1 HRM46.4 & & River & $\mathrm{N}$ & $3 / 31 / 94$ & 0.1 & 0.0273 & & \\
\hline Uranium-235 & Rich.Pmphs-1 HRM46.4 & & River & $\mathrm{N}$ & $12 / 9 / 96$ & 0.0211 & 0.0147 & & \\
\hline Uranium-235 & Rich.Pmphs-1 HRM46.4 & & River & $\mathrm{N}$ & $3 / 24 / 98$ & 0.0139 & 0.0114 & & \\
\hline Uranium-235 & Rich.Pmphs-1 HRM46.4 & & River & $\mathrm{N}$ & $12 / 4 / 01$ & 0.00974 & 0.0087 & 0.00768 & \\
\hline Uranium-235 & Rich.Pmphs-1 HRM46.4 & & River & $\mathrm{N}$ & $3 / 26 / 02$ & 0.00934 & 0.0085 & 0.00382 & \\
\hline Uranium-235 & Rich.Pmphs-1 HRM46.4 & & River & $\mathrm{N}$ & $3 / 30 / 04$ & 0.0105 & 0.0092 & 0.00416 & \\
\hline Uranium-235 & Rich.Pmphs-1 HRM46.4 & & River & $\mathrm{N}$ & $6 / 24 / 04$ & 0.0158 & 0.011 & 0.0101 & \\
\hline Uranium-235 & Rich.Pmphs-1 HRM46.4 & & River & $\mathrm{N}$ & $12 / 19 / 04$ & 0.0311 & 0.013 & 0.00361 & \\
\hline Uranium-235 & Rich.Pmphs-1 HRM46.4 & & River & $\mathrm{N}$ & $3 / 29 / 05$ & 0.0174 & 0.012 & 0.014 & \\
\hline Uranium-235 & Rich.Pmphs HRM 46.4 & & River & $\mathrm{N}$ & $2 / 22 / 94$ & 0.0143 & 0.0127 & & \\
\hline Uranium-235 & Rich.Pmphs HRM 46.4 & & River & $\mathrm{N}$ & $11 / 1 / 94$ & 0.0386 & 0.024 & & \\
\hline Uranium-235 & Rich.Pmphs HRM 46.4 & & River & $\mathrm{N}$ & $12 / 21 / 94$ & & & & \\
\hline Uranium-235 & Rich.Pmphs HRM 46.4 & & River & $\mathrm{N}$ & $3 / 7 / 95$ & 0.0244 & 0.0193 & & \\
\hline Uranium-235 & Rich.Pmphs HRM 46.4 & & River & $\mathrm{N}$ & $4 / 4 / 95$ & 0.0481 & 0.0213 & & \\
\hline Uranium-235 & Rich.Pmphs HRM 46.4 & & River & $\mathrm{N}$ & $12 / 4 / 96$ & 0.0151 & 0.0128 & & \\
\hline Uranium-235 & Rich.Pmphs HRM 46.4 & & River & $\mathrm{N}$ & $2 / 3 / 97$ & 0.016 & 0.0137 & & \\
\hline Uranium-235 & Rich.Pmphs HRM 46.4 & & River & $\mathrm{N}$ & 9/3/97 & 0.0131 & 0.0107 & & \\
\hline
\end{tabular}


Table A.3. (contd)

\begin{tabular}{|c|c|c|c|c|c|c|c|c|c|}
\hline Analyte & Location & $\begin{array}{l}\text { Sample } \\
\text { Number }\end{array}$ & $\begin{array}{c}\text { Sampled } \\
\text { From }\end{array}$ & $\begin{array}{c}\text { Filter } \\
\text { Flag }\end{array}$ & $\begin{array}{l}\text { Sample } \\
\text { Date }\end{array}$ & $\begin{array}{l}\text { Value } \\
\text { (pCi/L) }\end{array}$ & $\begin{array}{c}\text { Counting } \\
\text { Error }\end{array}$ & MDA & $\begin{array}{l}\text { Quali- } \\
\text { fier }\end{array}$ \\
\hline Uranium-235 & "Rich.Pmphs HRM 46.4 & & River & $\mathrm{N \textrm {N }}$ & $\begin{array}{ll}10 / 8 / 97 \\
\end{array}$ & $\begin{array}{c}0.0168 \\
\end{array}$ & $\begin{array}{c}0.0139 \\
\end{array}$ & & \\
\hline Uranium-235 & Rich.Pmphs HRM 46.4 & & River & $\mathrm{N}$ & $4 / 8 / 98$ & 0.0172 & 0.0135 & & \\
\hline Uranium-235 & Rich.Pmphs HRM 46.4 & & River & $\mathrm{N}$ & $6 / 30 / 98$ & 0.0237 & 0.0145 & & \\
\hline Uranium-235 & Rich.Pmphs HRM 46.4 & & River & $\mathrm{N}$ & $5 / 2 / 01$ & 0.0111 & 0.0083 & 0.00326 & \\
\hline Uranium-235 & Rich.Pmphs HRM 46.4 & & River & $\mathrm{N}$ & $11 / 27 / 01$ & 0.0119 & 0.0089 & 0.01 & \\
\hline Uranium-235 & Rich.Pmphs HRM 46.4 & & River & $\mathrm{N}$ & $1 / 3 / 02$ & 0.0121 & 0.0097 & 0.00822 & \\
\hline Uranium-235 & Rich.Pmphs HRM 46.4 & & River & $\mathrm{N}$ & $4 / 3 / 02$ & 0.0106 & 0.0093 & 0.00419 & \\
\hline Uranium-235 & Rich.Pmphs HRM 46.4 & & River & $\mathrm{N}$ & $9 / 4 / 02$ & 0.00959 & 0.0086 & 0.00389 & \\
\hline Uranium-235 & Rich.Pmphs HRM 46.4 & & River & $\mathrm{N}$ & $4 / 2 / 03$ & 0.0149 & 0.011 & 0.0112 & \\
\hline Uranium-235 & Rich.Pmphs HRM 46.4 & & River & $\mathrm{N}$ & $5 / 6 / 04$ & 0.0118 & 0.0083 & 0.00399 & \\
\hline Uranium-235 & 331 Bldg. 300 Area & B0HRH1 & \begin{tabular}{|l} 
Drinking \\
\end{tabular} & $\mathrm{N}$ & $4 / 15 / 96$ & -0.00106 & 0.0089 & & $\mathrm{U}$ \\
\hline Uranium-235 & 300 Spr DR 7 -4 & B12T15 & River & $\mathrm{N}$ & $8 / 27 / 01$ & 0.00739 & 0.0081 & 0.00415 & $\bar{U}$ \\
\hline Uranium-235 & 300 Spr $9-4$ & B12T17 & River & $\mathrm{N}$ & $8 / 27 / 01$ & 0.00187 & 0.0079 & 0.0145 & $\mathrm{U}$ \\
\hline Uranium-235 & 300 Spr 7 -4 & B12T13 & River & $\mathrm{N}$ & $8 / 27 / 01$ & 0.0085 & 0.0084 & 0.00401 & $\mathrm{U}$ \\
\hline Uranium-235 & 300 Spr 7 -3 & B12RR9 & River & $\mathrm{N}$ & $8 / 27 / 01$ & 0.00849 & 0.0083 & 0.00883 & $\mathrm{U}$ \\
\hline Uranium-235 & 300 Spr $14-4$ & B12T25 & River & $\mathrm{N}$ & $8 / 27 / 01$ & 0.0066 & 0.0075 & 0.00384 & $\mathrm{U}$ \\
\hline Uranium-235 & 300 Spr $14-1$ & B12RX9 & River & $\mathrm{N}$ & $8 / 27 / 01$ & 0.00885 & 0.01 & 0.014 & $\bar{U}$ \\
\hline Uranium-235 & 300 Area-10 HRM 43.1 & B0C5C6 & River & $\mathrm{N}$ & $8 / 26 / 94$ & 0.00269 & 0.0347 & & $\mathrm{U}$ \\
\hline Uranium-235 & 300 Area-10 HRM 43.1 & B0J8Y6 & River & $\mathrm{N}$ & $9 / 20 / 96$ & 0.0116 & 0.0122 & & $\mathrm{U}$ \\
\hline Uranium-235 & 300 Area-10 HRM 43.1 & B0PVR3 & River & $\mathrm{N}$ & 9/15/98 & 0.000768 & 0.0146 & & $\overline{\mathrm{U}}$ \\
\hline Uranium-235 & 300 Area-10 HRM 43.1 & B0WB28 & River & $\mathrm{N}$ & $9 / 16 / 99$ & 0.00986 & 0.0074 & 0.00981 & $\overline{\mathrm{U}}$ \\
\hline Uranium-235 & 300 Area-10 HRM 43.1 & B106Y3 & River & $\mathrm{N}$ & $9 / 19 / 00$ & 0.00209 & 0.0027 & 0.0117 & $\bar{U}$ \\
\hline Uranium-235 & 300 Area-10 HRM 43.1 & B158M0 & River & $\mathrm{N}$ & $9 / 10 / 02$ & 0.0117 & 0.012 & 0.0151 & $\mathrm{U}$ \\
\hline Uranium-235 & 300 Area-10 HRM 43.1 & B17CK0 & River & $\mathrm{N}$ & 9/9/03 & 0.0112 & 0.011 & 0.0122 & $\bar{U}$ \\
\hline Uranium-235 & 300 Area-10 HRM 43.1 & & River & $\overline{\mathrm{N}}$ & $9 / 15 / 05$ & 0.0118 & 0.011 & 0.0133 & $\bar{U}$ \\
\hline Uranium-235 & 300 Area SPRING 42-2 & & River & $\mathrm{N}$ & $9 / 15 / 05$ & 0.01 & 0.0095 & 0.0121 & $\bar{U}$ \\
\hline Uranium-235 & 300 Area Spr DR 42-2 & & River & $\mathrm{N}$ & $9 / 15 / 05$ & 0.00763 & 0.014 & 0.0264 & $\bar{U}$ \\
\hline Uranium-235 & 300 Area Shr HRM42.9 & B0WB56 & River & $\mathrm{N}$ & $9 / 16 / 99$ & 0.00436 & 0.0059 & 0.0192 & $\bar{U}$ \\
\hline Uranium-235 & 300 Area Shr HRM42.9 & B10782 & River & $\mathrm{N}$ & $9 / 19 / 00$ & 0.00264 & 0.0026 & 0.00405 & $\bar{U}$ \\
\hline Uranium-235 & 300 Area Shr HRM42.9 & B12TR6 & River & $\mathrm{N}$ & $9 / 13 / 01$ & 0.00777 & 0.0079 & 0.00376 & $\mathrm{U}$ \\
\hline Uranium-235 & 300 Area Shr HRM42.9 & B158Y9 & River & $\mathrm{N}$ & $9 / 10 / 02$ & -0.000357 & 0.006 & 0.00808 & $\mathrm{U}$ \\
\hline Uranium-235 & 300 Area Shr HRM42.9 & B1B7C7 & River & $\mathrm{N}$ & $9 / 15 / 04$ & 0.0118 & 0.0089 & 0.00427 & $\bar{U}$ \\
\hline Uranium-235 & 300 Area Shr HRM42.9 & & River & $\mathrm{N}$ & $9 / 15 / 05$ & 0.00648 & 0.0073 & 0.00495 & $\bar{U}$ \\
\hline Uranium-235 & 300 Area Shr HRM42.5 & B0WB55 & River & $\mathrm{N}$ & 9/16/99 & -0.00126 & 0.0032 & 0.0119 & $\bar{U}$ \\
\hline Uranium-235 & 300 Area Shr HRM42.5 & B10779 & River & $\mathrm{N}$ & $9 / 19 / 00$ & 0.00674 & 0.0051 & 0.00749 & $\bar{U}$ \\
\hline Uranium-235 & 300 Area Shr HRM42.5 & B12TR2 & River & $\mathrm{N}$ & $9 / 13 / 01$ & 0.000331 & 0.0061 & 0.0115 & $\mathrm{U}$ \\
\hline Uranium-235 & 300 Area Shr HRM42.5 & B158Y6 & River & $\mathrm{N}$ & $9 / 10 / 02$ & -0.000699 & 0.0037 & 0.00358 & $\mathrm{U}$ \\
\hline Uranium-235 & 300 Area Shr HRM42.1 & B0WB54 & River & $\mathrm{N}$ & 9/16/99 & 0.0079 & 0.0068 & 0.0129 & $\mathrm{U}$ \\
\hline Uranium-235 & 300 Area Shr HRM42.1 & B10776 & River & $\mathrm{N}$ & $9 / 19 / 00$ & 0.0014 & 0.0014 & 0.00321 & $\bar{U}$ \\
\hline Uranium-235 & 300 Area Shr HRM42.1 & B158Y3 & River & $\mathrm{N}$ & $9 / 10 / 02$ & 0.00452 & 0.008 & 0.0125 & $\bar{U}$ \\
\hline Uranium-235 & 300 Area Shr HRM42.1 & B17CW9 & River & $\mathrm{N}$ & $9 / 9 / 03$ & 0.00339 & 0.006 & 0.00364 & $\overline{\mathrm{U}}$ \\
\hline Uranium-235 & 300 Area Shr HRM42.1 & B1B7C3 & River & $\overline{\mathrm{N}}$ & $9 / 15 / 04$ & 0.0119 & 0.0097 & 0.00495 & $\bar{U}$ \\
\hline Uranium-235 & 300 Area Shr HRM41.5 & B0WB53 & River & $\mathrm{N}$ & $9 / 16 / 99$ & 0.0074 & 0.0076 & 0.0182 & $\bar{U}$ \\
\hline Uranium-235 & 300 Area Shr HRM41.5 & B10773 & River & $\mathrm{N}$ & $9 / 19 / 00$ & 0.00198 & 0.0032 & 0.0165 & $\mathrm{U}$ \\
\hline Uranium-235 & 300 Area Shr HRM41.5 & B12TP4 & River & $\mathrm{N}$ & $9 / 13 / 01$ & 0.000713 & 0.0057 & 0.00548 & $\mathrm{U}$ \\
\hline Uranium-235 & 300 Area Shr HRM41.5 & B17CW5 & River & $\mathrm{N}$ & 9/9/03 & 0.00331 & 0.0059 & 0.0036 & $\mathrm{U}$ \\
\hline Uranium-235 & 300 Area Shr HRM41.5 & B1B7B9 & River & $\mathrm{N}$ & $9 / 15 / 04$ & 0.00177 & 0.0052 & 0.0071 & $\mathrm{U}$ \\
\hline Uranium-235 & 300 Area Shr HRM41.5 & & River & $\mathrm{N}$ & $9 / 15 / 05$ & 0.00785 & 0.0071 & 0.00392 & $\mathrm{U}$ \\
\hline
\end{tabular}


Table A.3. (contd)

\begin{tabular}{|c|c|c|c|c|c|c|c|c|c|}
\hline Analyte & Location & $\begin{array}{l}\text { Sample } \\
\text { Number }\end{array}$ & $\begin{array}{c}\text { Sampled } \\
\text { From }\end{array}$ & $\begin{array}{c}\text { Filter } \\
\text { Flag } \\
\end{array}$ & $\begin{array}{c}\text { Sample } \\
\text { Date }\end{array}$ & $\begin{array}{c}\text { Value } \\
\text { (pCi/L) }\end{array}$ & $\begin{array}{c}\text { Counting } \\
\text { Error }\end{array}$ & MDA & $\begin{array}{c}\text { Quali- } \\
\text { fier } \\
\end{array}$ \\
\hline Uranium-235 & 300 Area -9 HRM 43.1 & B0C5C5 & River & $\mathrm{N}$ & $8 / 26 / 94$ & 0.0255 & 0.052 & & $\mathrm{U}$ \\
\hline Uranium-235 & 300 Area -9 HRM 43.1 & B0G8B1 & River & $\mathrm{N}$ & 9/18/95 & 0.00274 & 0.0102 & & $\mathrm{U}$ \\
\hline Uranium-235 & 300 Area -9 HRM 43.1 & B0J8Y5 & River & $\mathrm{N}$ & 9/20/96 & 0.0116 & 0.0121 & & $\mathrm{U}$ \\
\hline Uranium-235 & 300 Area -8 HRM 43.1 & B0C5C4 & River & $\mathrm{N}$ & $8 / 26 / 94$ & 0.00514 & 0.0177 & & $\mathrm{U}$ \\
\hline Uranium-235 & 300 Area -8 HRM 43.1 & B0J8Y4 & River & $\mathrm{N}$ & $9 / 20 / 96$ & 0.0052 & 0.00854 & & $\mathrm{U}$ \\
\hline Uranium-235 & 300 Area -8 HRM 43.1 & B0PVR1 & River & $\mathrm{N}$ & $9 / 15 / 98$ & -0.00333 & 0.00867 & & $\bar{U}$ \\
\hline Uranium-235 & 300 Area -7 HRM 43.1 & B0C5C3 & River & $\mathrm{N}$ & $8 / 26 / 94$ & 0.000346 & 0.0189 & & $\bar{U}$ \\
\hline Uranium-235 & 300 Area -7 HRM 43.1 & B0G899 & River & $\mathrm{N}$ & 9/18/95 & 0.000862 & 0.0105 & & $\bar{U}$ \\
\hline Uranium-235 & 300 Area -7 HRM 43.1 & B0J8Y3 & River & $\mathrm{N}$ & $9 / 20 / 96$ & 0.0106 & 0.0148 & & $\bar{U}$ \\
\hline Uranium-235 & 300 Area -7 HRM 43.1 & B0LVW3 & River & $\mathrm{N}$ & $8 / 25 / 97$ & 0.0000148 & 0.00933 & & $\bar{U}$ \\
\hline Uranium-235 & 300 Area -7 HRM 43.1 & B0PVR0 & River & $\mathrm{N}$ & $9 / 15 / 98$ & -0.0154 & 0.0244 & & $\bar{U}$ \\
\hline Uranium-235 & 300 Area -7 HRM 43.1 & B0WB27 & River & $\mathrm{N}$ & $9 / 16 / 99$ & 0.00978 & 0.0077 & 0.0131 & $\bar{U}$ \\
\hline Uranium-235 & 300 Area -7 HRM 43.1 & B106Y1 & River & $\mathrm{N}$ & $9 / 19 / 00$ & 0.011 & 0.0087 & 0.0144 & $\mathrm{U}$ \\
\hline Uranium-235 & 300 Area -7 HRM 43.1 & B12TC4 & River & $\mathrm{N}$ & $9 / 13 / 01$ & -0.00101 & 0.0043 & 0.00822 & $\mathrm{U}$ \\
\hline Uranium-235 & 300 Area -7 HRM 43.1 & B158L9 & River & $\mathrm{N}$ & $9 / 10 / 02$ & 0.00866 & 0.0098 & 0.00542 & $\mathrm{U}$ \\
\hline Uranium-235 & 300 Area -7 HRM 43.1 & B17CJ8 & River & $\mathrm{N}$ & $9 / 9 / 03$ & 0.000897 & 0.0049 & 0.00383 & $\mathrm{U}$ \\
\hline Uranium-235 & 300 Area -7 HRM 43.1 & B1B724 & River & $\mathrm{N}$ & $9 / 15 / 04$ & 0.00153 & 0.011 & 0.0222 & $\mathrm{U}$ \\
\hline Uranium-235 & 300 Area -7 HRM 43.1 & & River & $\mathrm{N}$ & 9/15/05 & 0.00624 & 0.011 & 0.0174 & $\mathrm{U}$ \\
\hline Uranium-235 & 300 Area -6 HRM 43.1 & B0C5C2 & River & $\mathrm{N}$ & $8 / 26 / 94$ & 0.00907 & 0.0283 & & $\mathrm{U}$ \\
\hline Uranium-235 & 300 Area -6 HRM 43.1 & B0G898 & River & $\mathrm{N}$ & $9 / 18 / 95$ & 0.00597 & 0.0116 & & $\bar{U}$ \\
\hline Uranium-235 & 300 Area -5 HRM 43.1 & B0C5C1 & River & $\mathrm{N}$ & $8 / 26 / 94$ & -0.00775 & 0.0129 & & $\bar{U}$ \\
\hline Uranium-235 & 300 Area -5 HRM 43.1 & B0G897 & River & $\mathrm{N}$ & $9 / 18 / 95$ & 0.00783 & 0.014 & & $\mathrm{U}$ \\
\hline Uranium-235 & 300 Area -5 HRM 43.1 & B0J8Y0 & River & $\mathrm{N}$ & 9/20/96 & 0.00951 & 0.011 & & $\mathrm{U}$ \\
\hline Uranium-235 & 300 Area -5 HRM 43.1 & B0LVW1 & River & $\mathrm{N}$ & $8 / 25 / 97$ & 0.00475 & 0.011 & & $\mathrm{U}$ \\
\hline Uranium-235 & 300 Area -5 HRM 43.1 & B0PVP8 & River & $\mathrm{N}$ & 9/15/98 & 0.00412 & 0.00966 & & $\mathrm{U}$ \\
\hline Uranium-235 & 300 Area -5 HRM 43.1 & B0WB26 & River & $\mathrm{N}$ & 9/16/99 & 0.0158 & 0.012 & 0.0197 & $\mathrm{U}$ \\
\hline Uranium-235 & 300 Area -5 HRM 43.1 & B106X9 & River & $\mathrm{N}$ & $9 / 19 / 00$ & 0.0114 & 0.0096 & 0.0172 & $\mathrm{U}$ \\
\hline Uranium-235 & 300 Area -5 HRM 43.1 & B12TC2 & River & $\mathrm{N}$ & $9 / 13 / 01$ & -0.000425 & 0.0041 & 0.00393 & $\bar{U}$ \\
\hline Uranium-235 & 300 Area -5 HRM 43.1 & B158L8 & River & $\mathrm{N}$ & $9 / 10 / 02$ & $\begin{array}{l}-0.00062 \\
\end{array}$ & 0.0076 & 0.0167 & $\bar{U}$ \\
\hline Uranium-235 & 300 Area -5 HRM 43.1 & B17CJ6 & River & $\mathrm{N}$ & $9 / 9 / 03$ & -0.00172 & 0.0063 & 0.0151 & $\mathrm{U}$ \\
\hline Uranium-235 & 300 Area -5 HRM 43.1 & B1B723 & River & $\mathrm{N}$ & $9 / 15 / 04$ & 0.0131 & 0.017 & 0.028 & $\mathrm{U}$ \\
\hline Uranium-235 & 300 Area -5 HRM 43.1 & & River & $\mathrm{N}$ & $9 / 15 / 05$ & 0.00209 & 0.011 & 0.0207 & $\mathrm{U}$ \\
\hline Uranium-235 & 300 Area -4 HRM 43.1 & B0С5C0 & River & $\mathrm{N}$ & $8 / 26 / 94$ & 0.0103 & 0.0213 & & $\mathrm{U}$ \\
\hline Uranium-235 & 300 Area -4 HRM 43.1 & B0G896 & River & $\mathrm{N}$ & 9/18/95 & 0.000782 & 0.00767 & & $\mathrm{U}$ \\
\hline Uranium-235 & 300 Area -4 HRM 43.1 & B0J8X8 & River & $\mathrm{N}$ & 9/20/96 & -0.00288 & 0.00936 & & $\mathrm{U}$ \\
\hline Uranium-235 & 300 Area -4 HRM 43.1 & B0LVW0 & River & $\mathrm{N}$ & $8 / 25 / 97$ & 0.00866 & 0.00979 & & $\mathrm{U}$ \\
\hline Uranium-235 & 300 Area -4 HRM 43.1 & B0PVP7 & River & $\mathrm{N}$ & 9/15/98 & 0.00292 & 0.00849 & & $\mathrm{U}$ \\
\hline Uranium-235 & 300 Area -3 HRM 43.1 & B0С5B9 & River & $\mathrm{N}$ & 8/26/94 & 0.117 & 0.129 & & $\mathrm{U}$ \\
\hline Uranium-235 & 300 Area -3 HRM 43.1 & B0G895 & River & $\mathrm{N}$ & 9/18/95 & 0.00775 & 0.0109 & & $\mathrm{U}$ \\
\hline Uranium-235 & 300 Area -3 HRM 43.1 & B0J8X6 & River & $\mathrm{N}$ & 9/20/96 & -0.00334 & 0.00726 & & $\mathrm{U}$ \\
\hline Uranium-235 & 300 Area -3 HRM 43.1 & B0LVV9 & River & $\mathrm{N}$ & $8 / 25 / 97$ & 0.00301 & 0.00733 & & $\mathrm{U}$ \\
\hline Uranium-235 & 300 Area -3 HRM 43.1 & B0PVP6 & River & $\mathrm{N}$ & $9 / 15 / 98$ & -0.00844 & 0.00725 & & $\mathrm{U}$ \\
\hline Uranium-235 & 300 Area -3 HRM 43.1 & B0WB25 & River & $\mathrm{N}$ & $9 / 16 / 99$ & 0.00749 & 0.0065 & 0.012 & $\mathrm{U}$ \\
\hline Uranium-235 & 300 Area -3 HRM 43.1 & B106X7 & River & $\mathrm{N}$ & $9 / 19 / 00$ & -0.00178 & 0.0044 & 0.00893 & $\mathrm{U}$ \\
\hline Uranium-235 & 300 Area -3 HRM 43.1 & B158L7 & River & $\mathrm{N}$ & $9 / 10 / 02$ & 0.00333 & 0.006 & 0.00362 & $\mathrm{U}$ \\
\hline Uranium-235 & 300 Area -3 HRM 43.1 & B17CJ4 & River & $\mathrm{N}$ & 9/9/03 & 0.00294 & 0.0063 & 0.00425 & $\mathrm{U}$ \\
\hline Uranium-235 & 300 Area -3 HRM 43.1 & B1B722 & River & $\mathrm{N}$ & $9 / 15 / 04$ & 0.00671 & 0.0087 & 0.00683 & $\mathrm{U}$ \\
\hline Uranium-235 & 300 Area -3 HRM 43.1 & & River & $\mathrm{N}$ & $9 / 15 / 05$ & 0.0135 & 0.018 & 0.0286 & $\mathrm{U}$ \\
\hline
\end{tabular}


Table A.3. (contd)

\begin{tabular}{|c|c|c|c|c|c|c|c|c|c|}
\hline Analyte & Location & $\begin{array}{l}\text { Sample } \\
\text { Number }\end{array}$ & $\begin{array}{c}\text { Sampled } \\
\text { From }\end{array}$ & $\begin{array}{c}\text { Filter } \\
\text { Flag }\end{array}$ & $\begin{array}{l}\text { Sample } \\
\text { Date } \\
\end{array}$ & $\begin{array}{c}\text { Value } \\
\text { (pCi/L) }\end{array}$ & $\begin{array}{c}\text { Counting } \\
\text { Error }\end{array}$ & MDA & $\begin{array}{l}\text { Quali- } \\
\text { fier } \\
\end{array}$ \\
\hline Uranium-235 & 300 Area -2 HRM 43.1 & B0C5B8 & $\begin{array}{l}\text { River } \\
\end{array}$ & $\mathrm{N}$ & $8 / 26 / 94$ & 0.00282 & 0.0335 & & 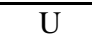 \\
\hline Uranium-235 & 300 Area -2 HRM 43.1 & B0G894 & River & $\mathrm{N}$ & $9 / 18 / 95$ & 0.00484 & 0.015 & & $\mathrm{U}$ \\
\hline Uranium-235 & 300 Area -2 HRM 43.1 & B0LVV8 & River & $\mathrm{N}$ & $8 / 25 / 97$ & 0.00783 & 0.0099 & & $\mathrm{U}$ \\
\hline Uranium-235 & 300 Area -2 HRM 43.1 & B0PVP5 & River & $\mathrm{N}$ & 9/15/98 & 0.00333 & 0.011 & & $\mathrm{U}$ \\
\hline Uranium-235 & 300 Area -2 HRM 43.1 & B0WB24 & River & $\mathrm{N}$ & 9/16/99 & 0.0121 & 0.0094 & 0.0158 & $\mathrm{U}$ \\
\hline Uranium-235 & 300 Area -2 HRM 43.1 & B12TB8 & River & $\mathrm{N}$ & $9 / 13 / 01$ & 0.00779 & 0.0083 & 0.00932 & $\mathrm{U}$ \\
\hline Uranium-235 & 300 Area -2 HRM 43.1 & B158L6 & River & $\mathrm{N}$ & $9 / 10 / 02$ & 0.00249 & 0.0058 & 0.00716 & $\mathrm{U}$ \\
\hline Uranium-235 & 300 Area -2 HRM 43.1 & B17CJ2 & River & $\mathrm{N}$ & 9/9/03 & 0.00785 & 0.0085 & 0.00433 & $\mathrm{U}$ \\
\hline Uranium-235 & 300 Area -2 HRM 43.1 & B1B721 & River & $\mathrm{N}$ & $9 / 15 / 04$ & 0.00354 & 0.0062 & 0.00595 & $\mathrm{U}$ \\
\hline Uranium-235 & 300 Area -2 HRM 43.1 & & River & $\mathrm{N}$ & $9 / 15 / 05$ & 0.00525 & 0.0061 & 0.00414 & $\mathrm{U}$ \\
\hline Uranium-235 & 300 Area -1 HRM 43.1 & B0C5B7 & River & $\mathrm{N}$ & $8 / 26 / 94$ & 0.0695 & 0.0976 & & $\mathrm{U}$ \\
\hline Uranium-235 & 300 Area -1 HRM 43.1 & B0LVV7 & River & $\mathrm{N}$ & $8 / 25 / 97$ & 0.00225 & 0.00645 & & $\mathrm{U}$ \\
\hline Uranium-235 & 300 Area -1 HRM 43.1 & B0PVP4 & River & $\mathrm{N}$ & $9 / 15 / 98$ & 0.00421 & 0.00977 & & $\mathrm{U}$ \\
\hline Uranium-235 & 300 Area -1 HRM 43.1 & B0WB23 & River & $\mathrm{N}$ & 9/16/99 & -0.00334 & 0.0069 & 0.0186 & $\mathrm{U}$ \\
\hline Uranium-235 & 300 Area -1 HRM 43.1 & B106X3 & River & $\mathrm{N}$ & $9 / 19 / 00$ & 0.00385 & 0.0031 & 0.00325 & $\mathrm{U}$ \\
\hline Uranium-235 & 300 Area -1 HRM 43.1 & B12TB6 & River & $\mathrm{N}$ & $9 / 13 / 01$ & 0.00652 & 0.0074 & 0.00731 & $\mathrm{U}$ \\
\hline Uranium-235 & 300 Area -1 HRM 43.1 & B158L5 & River & $\mathrm{N}$ & $9 / 10 / 02$ & 0.00339 & 0.006 & 0.00365 & $\mathrm{U}$ \\
\hline Uranium-235 & 300 Area -1 HRM 43.1 & B17CJ0 & River & $\mathrm{N}$ & $9 / 9 / 03$ & 0.00244 & 0.01 & 0.0173 & $\mathrm{U}$ \\
\hline Uranium-235 & 300 Area -1 HRM 43.1 & B1B720 & River & $\mathrm{N}$ & 9/15/04 & 0.00765 & 0.0098 & 0.00768 & $\mathrm{U}$ \\
\hline Uranium-235 & 300 Area -1 HRM 43.1 & & River & $\mathrm{N}$ & $9 / 15 / 05$ & -0.000848 & 0.0066 & 0.0173 & $\mathrm{U}$ \\
\hline Uranium-235 & 300 Area & B09QT2 & Drinking & $\mathrm{N}$ & $3 / 29 / 94$ & 0.00496 & 0.00855 & & $\mathrm{U}$ \\
\hline Uranium-235 & 300 Area & B0F909 & Drinking & $\mathrm{N}$ & $6 / 20 / 95$ & 0.00777 & 0.0109 & & $\mathrm{U}$ \\
\hline Uranium-235 & 300 Area & B0G537 & Drinking & $\mathrm{N}$ & $10 / 10 / 95$ & 0.00975 & 0.014 & & $\bar{U}$ \\
\hline Uranium-235 & 300 Area & B0H524 & Drinking & $\mathrm{N}$ & $3 / 27 / 96$ & 0.00782 & 0.0114 & & $\mathrm{U}$ \\
\hline Uranium-235 & 300 Area & B0JFJ4 & Drinking & $\mathrm{N}$ & $1 / 6 / 97$ & 0.0312 & 0.0379 & & $\mathrm{U}$ \\
\hline Uranium-235 & 300 Area & B0K6X1 & Drinking & $\mathrm{N}$ & 7/17/97 & 0.00979 & 0.0112 & & $\mathrm{U}$ \\
\hline Uranium-235 & 300 Area & B0NHR3 & Drinking & $\mathrm{N}$ & $7 / 15 / 98$ & 0.00956 & 0.0123 & & $\mathrm{U}$ \\
\hline Uranium-235 & 300 Area & B19HD4 & River & $\mathrm{N}$ & $6 / 10 / 04$ & 0.00965 & 0.012 & 0.0159 & $\mathrm{U}$ \\
\hline Uranium-235 & 300 Area & B1BCB0 & River & $\mathrm{N}$ & 9/24/04 & 0.00861 & 0.011 & 0.017 & $\mathrm{U}$ \\
\hline Uranium-235 & 300 Area & & River & $\mathrm{N}$ & $9 / 15 / 05$ & 0.0119 & 0.011 & 0.0148 & $\mathrm{U}$ \\
\hline Uranium-235 & 300 Area -2 HRM 43.1 & B106X5 & River & $\mathrm{N}$ & $9 / 19 / 00$ & 0.00875 & 0.0058 & 0.00364 & $\mathrm{~J}$ \\
\hline Uranium-235 & 300 Area & B0P8V0 & \begin{tabular}{|l|} 
Drinking \\
\end{tabular} & $\mathrm{N}$ & $10 / 8 / 98$ & 0.0422 & 0.02 & 0.0147 & $\mathrm{~J}$ \\
\hline Uranium-235 & 300 Area & B0R233 & \begin{tabular}{|l|} 
Drinking \\
\end{tabular} & $\mathrm{N}$ & $12 / 30 / 98$ & 0.0542 & 0.023 & 0.00623 & $\mathrm{~J}$ \\
\hline Uranium-235 & 300 Spr DR 9 -4 & B12T19 & River & $\mathrm{N}$ & $8 / 27 / 01$ & 0.0103 & 0.009 & 0.00919 & \\
\hline Uranium-235 & 300 Spr DR 9 -3 & B12RV9 & River & $\mathrm{N}$ & $8 / 27 / 01$ & 0.0782 & 0.021 & 0.0076 & \\
\hline Uranium-235 & 300 Spr DR 9 -2 & B12RV7 & River & $\mathrm{N}$ & $8 / 27 / 01$ & 0.374 & 0.047 & 0.0102 & \\
\hline Uranium-235 & 300 Spr DR 9 -1 & B12RV5 & River & $\mathrm{N}$ & $8 / 27 / 01$ & 0.288 & 0.041 & 0.00797 & \\
\hline Uranium-235 & 300 Spr DR 7 -3 & B12RT5 & River & $\mathrm{N}$ & $8 / 27 / 01$ & 0.0132 & 0.0095 & 0.00373 & \\
\hline Uranium-235 & 300 Spr DR 7 -2 & B12RT3 & River & $\mathrm{N}$ & $8 / 27 / 01$ & 0.0141 & 0.01 & 0.00907 & \\
\hline Uranium-235 & 300 Spr DR 7 -1 & B12RT1 & River & $\mathrm{N}$ & $8 / 27 / 01$ & 0.0617 & 0.019 & 0.00947 & \\
\hline Uranium-235 & 300 Spr DR $11-4$ & B12T23 & River & $\mathrm{N}$ & $8 / 27 / 01$ & 0.017 & 0.012 & 0.00499 & \\
\hline Uranium-235 & 300 Spr DR 11 -3 & B12RX5 & River & $\mathrm{N}$ & $8 / 27 / 01$ & 0.0307 & 0.016 & 0.00541 & \\
\hline Uranium-235 & 300 Spr DR 11 -2 & B12RX3 & River & $\mathrm{N}$ & $8 / 27 / 01$ & 0.0251 & 0.013 & 0.00385 & \\
\hline Uranium-235 & 300 Spr DR $11-1$ & B12RX1 & River & $\mathrm{N}$ & $8 / 27 / 01$ & 0.0937 & 0.024 & 0.00404 & \\
\hline Uranium-235 & 300 Spr 9 THRU Spr 11 & B12RW1 & River & $\mathrm{N}$ & $8 / 27 / 01$ & 0.0187 & 0.011 & 0.00373 & \\
\hline Uranium-235 & 300 Spr $9-3$ & B12RV3 & River & $\mathrm{N}$ & $8 / 27 / 01$ & 0.0139 & 0.011 & 0.0101 & \\
\hline Uranium-235 & 300 Spr $9-2$ & B12RV1 & River & $\mathrm{N}$ & $8 / 27 / 01$ & 0.0607 & 0.023 & 0.00578 & \\
\hline Uranium-235 & 300 Spr $9-1$ & B12RT9 & River & $\mathrm{N}$ & $8 / 27 / 01$ & 1.14 & 0.082 & 0.00828 & \\
\hline
\end{tabular}


Table A.3. (contd)

\begin{tabular}{|c|c|c|c|c|c|c|c|c|c|}
\hline Analyte & Location & $\begin{array}{c}\text { Sample } \\
\text { Number }\end{array}$ & $\begin{array}{c}\text { Sampled } \\
\text { From }\end{array}$ & $\begin{array}{c}\text { Filter } \\
\text { Flag }\end{array}$ & $\begin{array}{c}\text { Sample } \\
\text { Date }\end{array}$ & $\begin{array}{c}\text { Value } \\
(\mathrm{pCi} / \mathrm{L})\end{array}$ & $\begin{array}{c}\text { Counting } \\
\text { Error }\end{array}$ & MDA & $\begin{array}{l}\text { Quali- } \\
\text { fier }\end{array}$ \\
\hline Uranium-235 & 300 Spr 7 THRU Spr 9 & B12RT7 & $\begin{array}{l}\text { River } \\
\end{array}$ & $\overline{\mathrm{N}}$ & $8 / 27 / 01$ & 0.0107 & 0.0094 & 0.00424 & \\
\hline Uranium-235 & 300 Spr $7-2$ & B12RR7 & River & $\mathrm{N}$ & $8 / 27 / 01$ & 0.101 & 0.025 & 0.00822 & \\
\hline Uranium-235 & 300 Spr $7-1$ & B12RR5 & River & $\mathrm{N}$ & $8 / 27 / 01$ & 0.184 & 0.033 & 0.00979 & \\
\hline Uranium-235 & 300 Spr $14-3$ & B12RY3 & River & $\mathrm{N}$ & $8 / 27 / 01$ & 0.0116 & 0.0098 & 0.01 & \\
\hline Uranium-235 & 300 Spr $14-2$ & B12RY1 & River & $\mathrm{N}$ & $8 / 27 / 01$ & 0.0223 & 0.012 & 0.00969 & \\
\hline Uranium-235 & 300 Spr $11-4$ & B12T21 & River & $\mathrm{N}$ & $8 / 27 / 01$ & 0.0322 & 0.014 & 0.00385 & \\
\hline Uranium-235 & 300 Spr $11-3$ & B12RW9 & River & $\mathrm{N}$ & $8 / 27 / 01$ & 0.058 & 0.018 & 0.00353 & \\
\hline Uranium-235 & 300 Spr $11-2$ & B12RW7 & River & $\mathrm{N}$ & $8 / 27 / 01$ & 0.0274 & 0.013 & 0.00909 & \\
\hline Uranium-235 & 300 Spr $11-1$ & B12RW5 & River & $\mathrm{N}$ & $8 / 27 / 01$ & 0.248 & 0.036 & 0.00889 & \\
\hline Uranium-235 & 300 Area-10 HRM 43.1 & \begin{tabular}{|l|} 
B0G8B2 \\
\end{tabular} & River & $\mathrm{N}$ & $9 / 18 / 95$ & 0.0171 & 0.016 & & \\
\hline Uranium-235 & 300 Area-10 HRM 43.1 & B0LVW6 & River & $\mathrm{N}$ & $8 / 25 / 97$ & 0.0126 & 0.0113 & & \\
\hline Uranium-235 & 300 Area-10 HRM 43.1 & B12TC6 & River & $\mathrm{N}$ & $9 / 13 / 01$ & 0.0191 & 0.012 & 0.00405 & \\
\hline Uranium-235 & 300 Area-10 HRM 43.1 & B1B725 & River & $\mathrm{N}$ & $9 / 15 / 04$ & 0.0348 & 0.017 & 0.00537 & \\
\hline Uranium-235 & 300 Area Shr HRM42.9 & B17CX7 & River & $\mathrm{N}$ & $9 / 9 / 03$ & 0.0161 & 0.01 & 0.0035 & \\
\hline Uranium-235 & 300 Area Shr HRM42.5 & B17CX3 & River & $\mathrm{N}$ & $9 / 9 / 03$ & 0.169 & 0.029 & 0.014 & \\
\hline Uranium-235 & 300 Area Shr HRM42.4 & B1B7H3 & River & $\mathrm{N}$ & $9 / 15 / 04$ & 0.0211 & 0.013 & 0.00541 & \\
\hline Uranium-235 & 300 Area Shr HRM42.1 & B12TP8 & River & $\mathrm{N}$ & $9 / 13 / 01$ & 0.0117 & 0.0098 & 0.0109 & \\
\hline Uranium-235 & 300 Area Shr HRM41.5 & B158Y0 & River & $\mathrm{N}$ & $9 / 10 / 02$ & 0.0106 & 0.0099 & 0.00472 & \\
\hline Uranium-235 & 300 Area Outfl13 & B19JC4 & River & $\mathrm{N}$ & $6 / 24 / 04$ & 0.166 & 0.038 & 0.00588 & \\
\hline Uranium-235 & 300 Area Outfl13 & B1B7H7 & River & $\mathrm{N}$ & $9 / 15 / 04$ & 0.169 & 0.037 & 0.0199 & \\
\hline Uranium-235 & 300 Area Outfl13 & B1BW54 & River & $\mathrm{N}$ & $12 / 19 / 04$ & 0.139 & 0.03 & 0.0165 & \\
\hline Uranium-235 & 300 Area Outfl13 & & River & $\mathrm{N}$ & $6 / 7 / 05$ & 0.182 & 0.032 & 0.0174 & \\
\hline Uranium-235 & 300 Area Outfl13 & & River & $\mathrm{N}$ & $9 / 15 / 05$ & 0.19 & 0.043 & 0.0199 & \\
\hline Uranium-235 & 300 Area -9 HRM 43.1 & \begin{tabular}{|l|l} 
B0LVW5 \\
\end{tabular} & River & $\mathrm{N}$ & $8 / 25 / 97$ & 0.0119 & 0.0108 & & \\
\hline Uranium-235 & 300 Area -8 HRM 43.1 & B0G8B0 & River & $\mathrm{N}$ & $9 / 18 / 95$ & 0.0132 & 0.0129 & & \\
\hline Uranium-235 & 300 Area -8 HRM 43.1 & B0LVW4 & River & $\mathrm{N}$ & $8 / 25 / 97$ & 0.0173 & 0.0135 & & \\
\hline Uranium-235 & 300 Area -6 HRM 43.1 & \begin{tabular}{|l|} 
B0J8Y2 \\
\end{tabular} & River & $\mathrm{N}$ & 9/20/96 & 0.0286 & 0.0188 & & \\
\hline Uranium-235 & 300 Area -6 HRM 43.1 & B0LVW2 & River & $\mathrm{N}$ & $8 / 25 / 97$ & 0.0108 & 0.01 & & \\
\hline Uranium-235 & 300 Area -3 HRM 43.1 & B12TC0 & River & $\mathrm{N}$ & $9 / 13 / 01$ & 0.0126 & 0.0092 & 0.0036 & \\
\hline Uranium-235 & 300 Area -2 HRM 43.1 & B0J8X4 & River & $\mathrm{N}$ & 9/20/96 & 0.0191 & 0.0142 & & \\
\hline Uranium-235 & 300 Area -1 HRM 43.1 & B0G893 & River & $\mathrm{N}$ & 9/18/95 & 0.0161 & 0.0133 & & \\
\hline Uranium-235 & 300 Area -1 HRM 43.1 & B0J8X2 & River & $\mathrm{N}$ & $9 / 20 / 96$ & 0.0214 & 0.0146 & & \\
\hline Uranium-235 & 300 Area & B0BP89 & Drinking & $\mathrm{N}$ & $6 / 21 / 94$ & 0.0178 & 0.0131 & & \\
\hline Uranium-235 & 300 Area & B0C477 & Drinking & $\mathrm{N}$ & $10 / 11 / 94$ & 0.0209 & 0.0152 & & \\
\hline Uranium-235 & 300 Area & B0D0Y8 & Drinking & $\mathrm{N}$ & $1 / 3 / 95$ & 0.0233 & 0.0177 & & \\
\hline Uranium-235 & 300 Area & B0DKB6 & Drinking & $\mathrm{N}$ & $3 / 27 / 95$ & 0.0287 & 0.0275 & & \\
\hline Uranium-235 & 300 Area & B0GML6 & Drinking & $\mathrm{N}$ & $1 / 4 / 96$ & 0.0208 & 0.0139 & & \\
\hline Uranium-235 & 300 Area & B0HPT1 & Drinking & $\mathrm{N}$ & $6 / 19 / 96$ & 0.0131 & 0.0124 & & \\
\hline Uranium-235 & 300 Area & B0J464 & Drinking & $\mathrm{N}$ & $10 / 9 / 96$ & 0.0184 & 0.0145 & & \\
\hline Uranium-235 & 300 Area & B0JV31 & Drinking & $\mathrm{N}$ & $3 / 25 / 97$ & 0.0561 & 0.0357 & & \\
\hline Uranium-235 & 300 Area & B0LHF7 & Drinking & $\mathrm{N}$ & 10/8/97 & 0.0412 & 0.0215 & & \\
\hline Uranium-235 & 300 Area & \begin{tabular}{|l|} 
S0LWT9 \\
\end{tabular} & Drinking & $\mathrm{N}$ & $12 / 30 / 97$ & 0.0375 & 0.0183 & & \\
\hline Uranium-235 & 300 Area & B0MTB2 & Drinking & $\mathrm{N}$ & $3 / 27 / 98$ & 0.0259 & 0.0208 & & \\
\hline
\end{tabular}

\section{A.1.4 Uranium-238 Surface Water Data}

There were 204 surface water samples of uranium-238 at the Richland Pumphouse location and 181 at the 300 Area location. The samples were collected between 1/25/1994 and 10/6/2005. The values are plotted in Figure A.4, and the data are presented in Table A.4. 


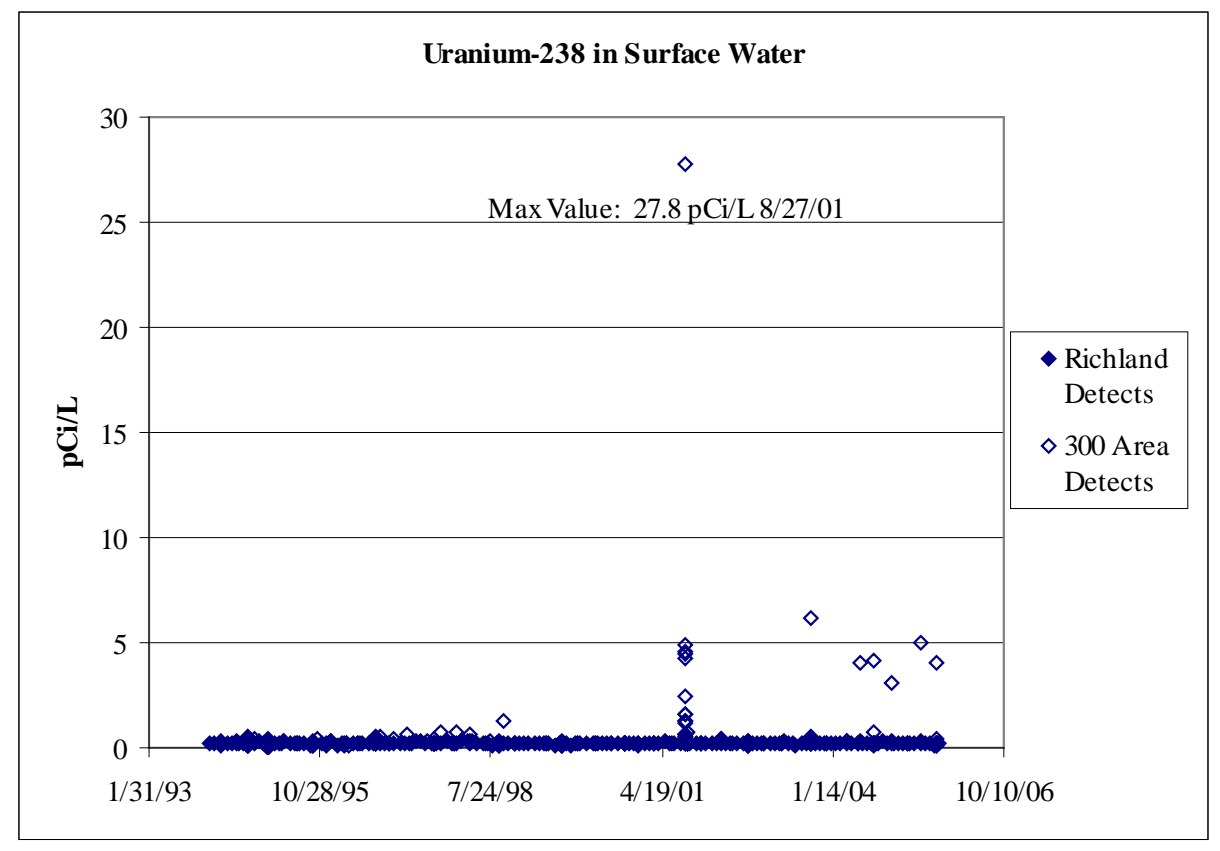

Figure A.4. Uranium-238 in Surface Water

Table A.4. Uranium-238 Data in Surface Water

\begin{tabular}{|c|c|c|c|c|c|c|c|c|c|}
\hline Analyte & Location & $\begin{array}{l}\text { Sample } \\
\text { Number }\end{array}$ & $\begin{array}{l}\text { Sampled } \\
\text { From }\end{array}$ & $\begin{array}{l}\text { Filter } \\
\text { Flag }\end{array}$ & $\begin{array}{c}\text { Sample } \\
\text { Date }\end{array}$ & $\begin{array}{c}\text { Value } \\
\text { (pCi/L) }\end{array}$ & $\begin{array}{c}\text { Counting } \\
\text { Error }\end{array}$ & MDA & $\begin{array}{l}\text { Quali- } \\
\text { fier }\end{array}$ \\
\hline "Uranium-238 & "Rich.Pmphs-1 HRM46.4 & & River & $\overline{\mathrm{N}}$ & $12 / 15 / 98$ & 0.233 & 0.039 & 0.0193 & $\overline{\mathrm{J}}$ \\
\hline Uranium-238 & Rich.Pmphs-1 HRM46.4 & & River & $\mathrm{N}$ & $12 / 15 / 98$ & 0.226 & 0.044 & 0.0159 & $\mathrm{~J}$ \\
\hline Uranium-238 & Rich.Pmphs HRM 46.4 & & River & $\mathrm{N}$ & $10 / 8 / 98$ & 0.223 & 0.042 & 0.0214 & $\mathrm{~J}$ \\
\hline Uranium-238 & Rich.Pmphs HRM 46.4 & & River & $\mathrm{N}$ & $10 / 28 / 98$ & 0.209 & 0.038 & 0.0142 & $\mathrm{~J}$ \\
\hline Uranium-238 & Rich.Pmphs HRM 46.4 & & River & $\mathrm{N}$ & $12 / 3 / 98$ & 0.228 & 0.041 & 0.0172 & $\mathrm{~J}$ \\
\hline Uranium-238 & Rich.Pmphs HRM 46.4 & & River & $\mathrm{N}$ & $12 / 30 / 98$ & 0.182 & 0.037 & 0.0126 & $\mathrm{~J}$ \\
\hline Uranium-238 & Rich.Pmphs HRM 46.4 & & River & $\mathrm{N}$ & 2/3/99 & 0.232 & 0.04 & 0.0143 & $\mathrm{~J}$ \\
\hline Uranium-238 & Rich.Pmphs HRM 46.4 & & River & $\mathrm{N}$ & 3/3/99 & 0.218 & 0.039 & 0.0141 & $\mathrm{~J}$ \\
\hline Uranium-238 & Rich.Pmphs HRM 46.4 & & River & $\mathrm{N}$ & $4 / 7 / 99$ & 0.201 & 0.038 & 0.0132 & $\mathrm{~J}$ \\
\hline Uranium-238 & Rich.Pmphs-1 HRM46.4 & & River & $\mathrm{N}$ & $3 / 31 / 94$ & 0.141 & 0.0329 & & \\
\hline Uranium-238 & Rich.Pmphs-1 HRM46.4 & & River & $\mathrm{N}$ & $7 / 1 / 94$ & 0.176 & 0.0421 & & \\
\hline Uranium-238 & Rich.Pmphs-1 HRM46.4 & & River & $\mathrm{N}$ & $8 / 26 / 94$ & 0.337 & 0.202 & & \\
\hline Uranium-238 & Rich.Pmphs-1 HRM46.4 & & River & $\mathrm{N}$ & $12 / 21 / 94$ & 0.329 & 0.12 & & \\
\hline Uranium-238 & Rich.Pmphs-1 HRM46.4 & & River & $\mathrm{N}$ & $3 / 17 / 95$ & 0.164 & 0.0336 & & \\
\hline Uranium-238 & Rich.Pmphs-1 HRM46.4 & & River & $\mathrm{N}$ & $6 / 16 / 95$ & 0.202 & 0.04 & & \\
\hline Uranium-238 & Rich.Pmphs-1 HRM46.4 & & River & $\mathrm{N}$ & 9/18/95 & 0.156 & 0.04 & & \\
\hline Uranium-238 & Rich.Pmphs-1 HRM46.4 & & River & $\mathrm{N}$ & $12 / 7 / 95$ & 0.156 & 0.041 & & \\
\hline Uranium-238 & Rich.Pmphs-1 HRM46.4 & & River & $\mathrm{N}$ & $3 / 18 / 96$ & 0.154 & 0.0362 & & \\
\hline Uranium-238 & Rich.Pmphs-1 HRM46.4 & & River & $\mathrm{N}$ & $3 / 18 / 96$ & 0.207 & 0.0483 & & \\
\hline Uranium-238 & Rich.Pmphs-1 HRM46.4 & & River & $\mathrm{N}$ & $6 / 7 / 96$ & 0.17 & 0.0357 & & \\
\hline Uranium-238 & Rich.Pmphs-1 HRM46.4 & & River & $\mathrm{N}$ & 9/20/96 & 0.2 & 0.0403 & & \\
\hline Uranium-238 & Rich.Pmphs-1 HRM46.4 & & River & $\mathrm{N}$ & $12 / 9 / 96$ & 0.209 & 0.0428 & & \\
\hline
\end{tabular}


Table A.4. (contd)

\begin{tabular}{|c|c|c|c|c|c|c|c|c|c|}
\hline Analyte & Location & $\begin{array}{l}\text { Sample } \\
\text { Number }\end{array}$ & $\begin{array}{c}\text { Sampled } \\
\text { From }\end{array}$ & \begin{tabular}{|c|} 
Filter \\
Flag \\
\end{tabular} & $\begin{array}{l}\text { Sample } \\
\text { Date }\end{array}$ & $\begin{array}{c}\text { Value } \\
\text { (pCi/L) }\end{array}$ & $\begin{array}{c}\text { Counting } \\
\text { Error }\end{array}$ & MDA & $\begin{array}{l}\text { Quali- } \\
\text { fier }\end{array}$ \\
\hline Uranium-238 & Rich.Pmphs-1 HRM46.4 & & 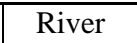 & $\mathrm{N}$ & $\begin{array}{ll}12 / 9 / 96 \\
\end{array}$ & $\begin{array}{l}0.196 \\
\end{array}$ & 0.0427 & & \\
\hline Uranium-238 & Rich.Pmphs-1 HRM46.4 & & River & $\mathrm{N}$ & $4 / 1 / 97$ & 0.218 & 0.0482 & & \\
\hline Uranium-238 & Rich.Pmphs-1 HRM46.4 & & River & $\mathrm{N}$ & $8 / 25 / 97$ & 0.161 & 0.034 & & \\
\hline Uranium-238 & Rich.Pmphs-1 HRM46.4 & & River & $\mathrm{N}$ & $12 / 19 / 97$ & 0.208 & 0.0387 & & \\
\hline Uranium-238 & Rich.Pmphs-1 HRM46.4 & & River & $\mathrm{N}$ & $12 / 19 / 97$ & 0.166 & 0.0359 & & \\
\hline Uranium-238 & Rich.Pmphs-1 HRM46.4 & & River & $\mathrm{N}$ & $3 / 24 / 98$ & 0.246 & 0.0442 & & \\
\hline Uranium-238 & Rich.Pmphs-1 HRM46.4 & & River & $\mathrm{N}$ & $3 / 24 / 98$ & 0.273 & 0.0507 & & \\
\hline Uranium-238 & Rich.Pmphs-1 HRM46.4 & & River & $\mathrm{N}$ & 6/23/98 & 0.221 & 0.0494 & & \\
\hline Uranium-238 & Rich.Pmphs-1 HRM46.4 & & River & $\mathrm{N}$ & 9/15/98 & 0.161 & 0.0338 & & \\
\hline Uranium-238 & Rich.Pmphs-1 HRM46.4 & & River & $\mathrm{N}$ & $6 / 14 / 99$ & 0.207 & 0.038 & 0.0119 & \\
\hline Uranium-238 & Rich.Pmphs-1 HRM46.4 & & River & $\mathrm{N}$ & $6 / 14 / 99$ & 0.221 & 0.04 & 0.0125 & \\
\hline Uranium-238 & Rich.Pmphs-1 HRM46.4 & & River & $\mathrm{N}$ & 9/16/99 & 0.151 & 0.032 & 0.0172 & \\
\hline Uranium-238 & Rich.Pmphs-1 HRM46.4 & & River & $\mathrm{N}$ & 12/6/99 & 0.173 & 0.039 & 0.0381 & \\
\hline Uranium-238 & Rich.Pmphs-1 HRM46.4 & & River & $\mathrm{N}$ & 12/6/99 & 0.192 & 0.039 & 0.0169 & \\
\hline Uranium-238 & Rich.Pmphs-1 HRM46.4 & & River & $\mathrm{N}$ & $3 / 28 / 00$ & 0.222 & 0.041 & 0.0389 & \\
\hline Uranium-238 & Rich.Pmphs-1 HRM46.4 & & River & $\mathrm{N}$ & $3 / 28 / 00$ & 0.212 & 0.038 & 0.0159 & \\
\hline Uranium-238 & Rich.Pmphs-1 HRM46.4 & & River & $\mathrm{N}$ & $6 / 20 / 00$ & 0.17 & 0.035 & 0.0126 & \\
\hline Uranium-238 & Rich.Pmphs-1 HRM46.4 & & River & $\mathrm{N}$ & 9/19/00 & 0.166 & 0.03 & 0.0097 & \\
\hline Uranium-238 & Rich.Pmphs-1 HRM46.4 & & River & $\mathrm{N}$ & $12 / 5 / 00$ & 0.156 & 0.029 & 0.00364 & \\
\hline Uranium-238 & Rich.Pmphs-1 HRM46.4 & & River & $\mathrm{N}$ & $12 / 5 / 00$ & 0.201 & 0.035 & 0.00837 & \\
\hline Uranium-238 & Rich.Pmphs-1 HRM46.4 & & River & $\mathrm{N}$ & $2 / 26 / 01$ & 0.226 & 0.034 & 0.00339 & \\
\hline Uranium-238 & Rich.Pmphs-1 HRM46.4 & & River & $\mathrm{N}$ & $2 / 26 / 01$ & 0.232 & 0.037 & 0.00383 & \\
\hline Uranium-238 & Rich.Pmphs-1 HRM46.4 & & River & $\mathrm{N}$ & $6 / 12 / 01$ & 0.223 & 0.035 & 0.0105 & \\
\hline Uranium-238 & Rich.Pmphs-1 HRM46.4 & & River & $\mathrm{N}$ & 9/13/01 & 0.183 & 0.032 & 0.00772 & \\
\hline Uranium-238 & Rich.Pmphs-1 HRM46.4 & & River & $\mathrm{N}$ & $12 / 4 / 01$ & 0.227 & 0.036 & 0.00368 & \\
\hline Uranium-238 & Rich.Pmphs-1 HRM46.4 & & River & $\mathrm{N}$ & $12 / 4 / 01$ & 0.205 & 0.035 & 0.00833 & \\
\hline Uranium-238 & Rich.Pmphs-1 HRM46.4 & & River & $\mathrm{N}$ & $3 / 26 / 02$ & 0.385 & 0.048 & 0.00395 & \\
\hline Uranium-238 & Rich.Pmphs-1 HRM46.4 & & River & $\mathrm{N}$ & $3 / 26 / 02$ & 0.373 & 0.046 & 0.011 & \\
\hline Uranium-238 & Rich.Pmphs-1 HRM46.4 & & River & $\mathrm{N}$ & $6 / 11 / 02$ & 0.161 & 0.029 & 0.00934 & \\
\hline Uranium-238 & Rich.Pmphs-1 HRM46.4 & & River & $\mathrm{N}$ & $9 / 10 / 02$ & 0.162 & 0.03 & 0.00366 & \\
\hline Uranium-238 & Rich.Pmphs-1 HRM46.4 & & River & $\mathrm{N}$ & $12 / 10 / 02$ & 0.19 & 0.037 & 0.00462 & \\
\hline Uranium-238 & Rich.Pmphs-1 HRM46.4 & & River & $\mathrm{N}$ & $12 / 10 / 02$ & 0.187 & 0.041 & 0.00579 & \\
\hline Uranium-238 & Rich.Pmphs-1 HRM46.4 & & River & $\mathrm{N}$ & $3 / 25 / 03$ & 0.215 & 0.034 & 0.00352 & \\
\hline Uranium-238 & Rich.Pmphs-1 HRM46.4 & & River & $\mathrm{N}$ & $3 / 25 / 03$ & 0.212 & 0.034 & 0.00351 & \\
\hline Uranium-238 & Rich.Pmphs-1 HRM46.4 & & River & $\mathrm{N}$ & $6 / 10 / 03$ & 0.143 & 0.041 & 0.0386 & \\
\hline Uranium-238 & Rich.Pmphs-1 HRM46.4 & & River & $\mathrm{N}$ & 9/9/03 & 0.252 & 0.038 & 0.0164 & \\
\hline Uranium-238 & Rich.Pmphs-1 HRM46.4 & & River & $\mathrm{N}$ & $12 / 8 / 03$ & 0.202 & 0.043 & 0.0249 & \\
\hline Uranium-238 & Rich.Pmphs-1 HRM46.4 & & River & $\mathrm{N}$ & $12 / 8 / 03$ & 0.231 & 0.052 & 0.0255 & \\
\hline Uranium-238 & Rich.Pmphs-1 HRM46.4 & & River & $\mathrm{N}$ & $3 / 30 / 04$ & 0.264 & 0.041 & 0.0142 & \\
\hline Uranium-238 & Rich.Pmphs-1 HRM46.4 & & River & $\mathrm{N}$ & $3 / 30 / 04$ & 0.291 & 0.042 & 0.00401 & \\
\hline Uranium-238 & Rich.Pmphs-1 HRM46.4 & & River & $\mathrm{N}$ & $6 / 24 / 04$ & 0.303 & 0.042 & 0.0193 & \\
\hline Uranium-238 & Rich.Pmphs-1 HRM46.4 & & River & $\mathrm{N}$ & $9 / 15 / 04$ & 0.228 & 0.047 & 0.00622 & \\
\hline Uranium-238 & Rich.Pmphs-1 HRM46.4 & & River & $\mathrm{N}$ & $12 / 19 / 04$ & 0.231 & 0.036 & 0.0123 & \\
\hline Uranium-238 & Rich.Pmphs-1 HRM46.4 & & River & $\mathrm{N}$ & $12 / 19 / 04$ & 0.354 & 0.045 & 0.0143 & \\
\hline Uranium-238 & Rich.Pmphs-1 HRM46.4 & & River & $\mathrm{N}$ & $3 / 29 / 05$ & 0.256 & 0.038 & 0.017 & \\
\hline Uranium-238 & Rich.Pmphs-1 HRM46.4 & & River & $\mathrm{N}$ & $3 / 29 / 05$ & 0.208 & 0.034 & 0.0153 & \\
\hline Uranium-238 & Rich.Pmphs-1 HRM46.4 & & River & $\mathrm{N}$ & $6 / 7 / 05$ & 0.333 & 0.041 & 0.00906 & \\
\hline Uranium-238 & Rich.Pmphs-1 HRM46.4 & & River & $\mathrm{N}$ & $9 / 14 / 05$ & 0.214 & 0.036 & 0.0129 & \\
\hline Uranium-238 & Rich.Pmphs HRM 46.4 & & River & $\mathrm{N}$ & $1 / 25 / 94$ & 0.254 & 0.0505 & & \\
\hline Uranium-238 & Rich.Pmphs HRM 46.4 & & River & $\mathrm{N}$ & $2 / 22 / 94$ & 0.173 & 0.0422 & & \\
\hline
\end{tabular}


Table A.4. (contd)

\begin{tabular}{|c|c|c|c|c|c|c|c|c|c|}
\hline Analyte & Location & $\begin{array}{c}\text { Sample } \\
\text { Number }\end{array}$ & $\begin{array}{c}\text { Sampled } \\
\text { From }\end{array}$ & \begin{tabular}{|c|} 
Filter \\
Flag
\end{tabular} & $\begin{array}{l}\text { Sample } \\
\text { Date }\end{array}$ & $\begin{array}{c}\text { Value } \\
(\mathrm{pCi} / \mathrm{L})\end{array}$ & $\begin{array}{l}\text { Counting } \\
\text { Error }\end{array}$ & MDA & $\begin{array}{l}\text { Quali- } \\
\text { fier }\end{array}$ \\
\hline Uranium-238 & Rich.Pmphs HRM 46.4 & & $\begin{array}{l}\text { River } \\
\end{array}$ & $\mathrm{N}$ & 3/29/94 & $\begin{array}{l}0.229 \\
\end{array}$ & 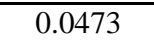 & & \\
\hline Uranium-238 & Rich.Pmphs HRM 46.4 & & River & $\mathrm{N}$ & $5 / 3 / 94$ & 0.198 & 0.0412 & & \\
\hline Uranium-238 & Rich.Pmphs HRM 46.4 & & River & $\mathrm{N}$ & $6 / 7 / 94$ & 0.185 & 0.041 & & \\
\hline Uranium-238 & Rich.Pmphs HRM 46.4 & & River & $\mathrm{N}$ & $7 / 6 / 94$ & 0.165 & 0.0404 & & \\
\hline Uranium-238 & Rich.Pmphs HRM 46.4 & & River & $\mathrm{N}$ & $8 / 1 / 94$ & 0.166 & 0.0379 & & \\
\hline Uranium-238 & Rich.Pmphs HRM 46.4 & & River & $\mathrm{N}$ & 9/6/94 & 0.528 & 0.124 & & \\
\hline Uranium-238 & Rich.Pmphs HRM 46.4 & & River & $\mathrm{N}$ & $10 / 4 / 94$ & 0.162 & 0.0356 & & \\
\hline Uranium-238 & Rich.Pmphs HRM 46.4 & & River & $\mathrm{N}$ & $11 / 1 / 94$ & 0.358 & 0.0718 & & \\
\hline Uranium-238 & Rich.Pmphs HRM 46.4 & & River & $\mathrm{N}$ & $12 / 6 / 94$ & 0.177 & 0.045 & & \\
\hline Uranium-238 & Rich.Pmphs HRM 46.4 & & River & $\mathrm{N}$ & $1 / 3 / 95$ & 0.000245 & 0.0000443 & & \\
\hline Uranium-238 & Rich.Pmphs HRM 46.4 & & River & $\mathrm{N}$ & $2 / 7 / 95$ & 0.193 & 0.042 & & \\
\hline Uranium-238 & Rich.Pmphs HRM 46.4 & & River & $\mathrm{N}$ & $3 / 7 / 95$ & 0.234 & 0.0507 & & \\
\hline Uranium-238 & Rich.Pmphs HRM 46.4 & & River & $\mathrm{N}$ & $4 / 4 / 95$ & 0.286 & 0.0514 & & \\
\hline Uranium-238 & Rich.Pmphs HRM 46.4 & & River & $\mathrm{N}$ & $5 / 2 / 95$ & 0.213 & 0.0418 & & \\
\hline Uranium-238 & Rich.Pmphs HRM 46.4 & & River & $\mathrm{N}$ & $6 / 6 / 95$ & 0.17 & 0.0402 & & \\
\hline Uranium-238 & Rich.Pmphs HRM 46.4 & & River & $\mathrm{N}$ & $7 / 5 / 95$ & 0.164 & 0.0441 & & \\
\hline Uranium-238 & Rich.Pmphs HRM 46.4 & & River & $\mathrm{N}$ & $8 / 1 / 95$ & 0.192 & 0.0408 & & \\
\hline Uranium-238 & Rich.Pmphs HRM 46.4 & & River & $\mathrm{N}$ & 9/6/95 & 0.142 & 0.0329 & & \\
\hline Uranium-238 & Rich.Pmphs HRM 46.4 & & River & $\mathrm{N}$ & $10 / 3 / 95$ & 0.233 & 0.0471 & & \\
\hline Uranium-238 & Rich.Pmphs HRM 46.4 & & River & $\mathrm{N}$ & $11 / 8 / 95$ & 0.2 & 0.0396 & & \\
\hline Uranium-238 & Rich.Pmphs HRM 46.4 & & River & $\mathrm{N}$ & $12 / 5 / 95$ & 0.189 & 0.0402 & & \\
\hline Uranium-238 & Rich.Pmphs HRM 46.4 & & River & $\mathrm{N}$ & $1 / 3 / 96$ & 0.269 & 0.0483 & & \\
\hline Uranium-238 & Rich.Pmphs HRM 46.4 & & River & $\mathrm{N}$ & $2 / 7 / 96$ & 0.158 & 0.0388 & & \\
\hline Uranium-238 & Rich.Pmphs HRM 46.4 & & River & $\mathrm{N}$ & $3 / 6 / 96$ & 0.209 & 0.0427 & & \\
\hline Uranium-238 & Rich.Pmphs HRM 46.4 & & River & $\mathrm{N}$ & $4 / 3 / 96$ & 0.222 & 0.042 & & \\
\hline Uranium-238 & Rich.Pmphs HRM 46.4 & & River & $\mathrm{N}$ & $5 / 8 / 96$ & 0.233 & 0.0444 & & \\
\hline Uranium-238 & Rich.Pmphs HRM 46.4 & & River & $\mathrm{N}$ & $6 / 5 / 96$ & 0.184 & 0.0375 & & \\
\hline Uranium-238 & Rich.Pmphs HRM 46.4 & & River & $\mathrm{N}$ & $7 / 2 / 96$ & 0.213 & 0.0444 & & \\
\hline Uranium-238 & Rich.Pmphs HRM 46.4 & & River & $\mathrm{N}$ & $8 / 7 / 96$ & 0.187 & 0.0361 & & \\
\hline Uranium-238 & Rich.Pmphs HRM 46.4 & & River & $\mathrm{N}$ & 9/4/96 & 0.204 & 0.0417 & & \\
\hline Uranium-238 & Rich.Pmphs HRM 46.4 & & River & $\mathrm{N}$ & 10/9/96 & 0.219 & 0.046 & & \\
\hline Uranium-238 & Rich.Pmphs HRM 46.4 & & River & $\mathrm{N}$ & 11/6/96 & 0.182 & 0.0668 & & \\
\hline Uranium-238 & Rich.Pmphs HRM 46.4 & & River & $\mathrm{N}$ & $12 / 4 / 96$ & 0.186 & 0.0392 & & \\
\hline Uranium-238 & Rich.Pmphs HRM 46.4 & & River & $\mathrm{N}$ & $12 / 30 / 96$ & 0.241 & 0.0517 & & \\
\hline Uranium-238 & Rich.Pmphs HRM 46.4 & & River & $\mathrm{N}$ & $2 / 3 / 97$ & 0.252 & 0.05 & & \\
\hline Uranium-238 & Rich.Pmphs HRM 46.4 & & River & $\mathrm{N}$ & $3 / 5 / 97$ & 0.25 & 0.044 & & \\
\hline Uranium-238 & Rich.Pmphs HRM 46.4 & & River & $\mathrm{N}$ & 4/9/97 & 0.227 & 0.049 & & \\
\hline Uranium-238 & Rich.Pmphs HRM 46.4 & & River & $\mathrm{N}$ & $5 / 7 / 97$ & 0.273 & 0.05 & & \\
\hline Uranium-238 & Rich.Pmphs HRM 46.4 & & River & $\mathrm{N}$ & $6 / 4 / 97$ & 0.29 & 0.0478 & & \\
\hline Uranium-238 & Rich.Pmphs HRM 46.4 & & River & $\mathrm{N}$ & 7/9/97 & 0.161 & 0.0359 & & \\
\hline Uranium-238 & Rich.Pmphs HRM 46.4 & & River & $\mathrm{N}$ & 8/6/97 & 0.191 & 0.0369 & & \\
\hline Uranium-238 & Rich.Pmphs HRM 46.4 & & River & $\mathrm{N}$ & 9/3/97 & 0.248 & 0.0412 & & \\
\hline Uranium-238 & Rich.Pmphs HRM 46.4 & & River & $\mathrm{N}$ & 10/8/97 & 0.196 & 0.0392 & & \\
\hline Uranium-238 & Rich.Pmphs HRM 46.4 & & River & $\mathrm{N}$ & $11 / 5 / 97$ & 0.274 & 0.0902 & & \\
\hline Uranium-238 & Rich.Pmphs HRM 46.4 & & River & $\mathrm{N}$ & $12 / 3 / 97$ & 0.255 & 0.0445 & & \\
\hline Uranium-238 & Rich.Pmphs HRM 46.4 & & River & $\mathrm{N}$ & $12 / 30 / 97$ & 0.251 & 0.0478 & & \\
\hline Uranium-238 & Rich.Pmphs HRM 46.4 & & River & $\mathrm{N}$ & $2 / 4 / 98$ & 0.291 & 0.0454 & & \\
\hline Uranium-238 & Rich.Pmphs HRM 46.4 & & River & $\mathrm{N}$ & $3 / 4 / 98$ & 0.291 & 0.105 & & \\
\hline Uranium-238 & Rich.Pmphs HRM 46.4 & & River & $\mathrm{N}$ & $4 / 8 / 98$ & 0.296 & 0.0508 & & \\
\hline Uranium-238 & Rich.Pmphs HRM 46.4 & & River & $\mathrm{N}$ & $5 / 7 / 98$ & 0.21 & 0.0508 & & \\
\hline
\end{tabular}


Table A.4. (contd)

\begin{tabular}{|c|c|c|c|c|c|c|c|c|c|}
\hline Analyte & Location & $\begin{array}{c}\text { Sample } \\
\text { Number }\end{array}$ & \begin{tabular}{|c|} 
Sampled \\
From
\end{tabular} & $\begin{array}{c}\text { Filter } \\
\text { Flag }\end{array}$ & $\begin{array}{c}\text { Sample } \\
\text { Date }\end{array}$ & $\begin{array}{c}\text { Value } \\
(\mathrm{pCi} / \mathrm{L})\end{array}$ & $\begin{array}{c}\text { Counting } \\
\text { Error }\end{array}$ & MDA & $\begin{array}{l}\text { Quali- } \\
\text { fier }\end{array}$ \\
\hline Uranium-238 & 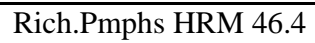 & & $\begin{array}{l}\text { River } \\
\end{array}$ & $\overline{\mathrm{N}}$ & $\begin{array}{ll}6 / 4 / 98 \\
\end{array}$ & $\begin{array}{l}0.227 \\
\end{array}$ & 0.0511 & & \\
\hline Uranium-238 & Rich.Pmphs HRM 46.4 & & River & $\mathrm{N}$ & $6 / 30 / 98$ & 0.21 & 0.041 & & \\
\hline Uranium-238 & Rich.Pmphs HRM 46.4 & & River & $\mathrm{N}$ & 7/29/98 & 0.148 & 0.0413 & & \\
\hline Uranium-238 & Rich.Pmphs HRM 46.4 & & River & $\mathrm{N}$ & 9/2/98 & 0.243 & 0.0647 & & \\
\hline Uranium-238 & Rich.Pmphs HRM 46.4 & & River & $\mathrm{N}$ & $5 / 5 / 99$ & 0.249 & 0.042 & 0.0146 & \\
\hline Uranium-238 & Rich.Pmphs HRM 46.4 & & River & $\mathrm{N}$ & $6 / 2 / 99$ & 0.24 & 0.04 & 0.0142 & \\
\hline Uranium-238 & Rich.Pmphs HRM 46.4 & & River & $\mathrm{N}$ & 6/30/99 & 0.188 & 0.036 & 0.0193 & \\
\hline Uranium-238 & Rich.Pmphs HRM 46.4 & & River & $\mathrm{N}$ & 7/28/99 & 0.151 & 0.031 & 0.0128 & \\
\hline Uranium-238 & Rich.Pmphs HRM 46.4 & & River & $\mathrm{N}$ & 9/1/99 & 0.176 & 0.035 & 0.0172 & \\
\hline Uranium-238 & Rich.Pmphs HRM 46.4 & & River & $\mathrm{N}$ & 10/6/99 & 0.239 & 0.04 & 0.0147 & \\
\hline Uranium-238 & Rich.Pmphs HRM 46.4 & & River & $\mathrm{N}$ & $11 / 3 / 99$ & 0.155 & 0.032 & 0.0177 & \\
\hline Uranium-238 & Rich.Pmphs HRM 46.4 & & River & $\mathrm{N}$ & $12 / 1 / 99$ & 0.233 & 0.037 & 0.00835 & \\
\hline Uranium-238 & Rich.Pmphs HRM 46.4 & & River & $\mathrm{N}$ & $12 / 29 / 99$ & 0.213 & 0.038 & 0.0156 & \\
\hline Uranium-238 & Rich.Pmphs HRM 46.4 & & River & $\mathrm{N}$ & $2 / 2 / 00$ & 0.189 & 0.032 & 0.00941 & \\
\hline Uranium-238 & Rich.Pmphs HRM 46.4 & & River & $\mathrm{N}$ & $3 / 8 / 00$ & 0.23 & 0.047 & 0.0168 & \\
\hline Uranium-238 & Rich.Pmphs HRM 46.4 & & River & $\mathrm{N}$ & $4 / 5 / 00$ & 0.231 & 0.04 & 0.0134 & \\
\hline Uranium-238 & Rich.Pmphs HRM 46.4 & & River & $\mathrm{N}$ & $5 / 3 / 00$ & 0.187 & 0.036 & 0.0193 & \\
\hline Uranium-238 & Rich.Pmphs HRM 46.4 & & River & $\mathrm{N}$ & $5 / 31 / 00$ & 0.181 & 0.034 & 0.0151 & \\
\hline Uranium-238 & Rich.Pmphs HRM 46.4 & & River & $\mathrm{N}$ & $6 / 29 / 00$ & 0.166 & 0.037 & 0.00565 & \\
\hline Uranium-238 & Rich.Pmphs HRM 46.4 & & River & $\mathrm{N}$ & $8 / 10 / 00$ & 0.163 & 0.039 & 0.022 & \\
\hline Uranium-238 & Rich.Pmphs HRM 46.4 & & River & $\mathrm{N}$ & $9 / 7 / 00$ & 0.229 & 0.042 & 0.0136 & \\
\hline Uranium-238 & Rich.Pmphs HRM 46.4 & & River & $\mathrm{N}$ & $10 / 5 / 00$ & 0.206 & 0.032 & 0.00739 & \\
\hline Uranium-238 & Rich.Pmphs HRM 46.4 & & River & $\mathrm{N}$ & $11 / 2 / 00$ & 0.195 & 0.031 & 0.00726 & \\
\hline Uranium-238 & Rich.Pmphs HRM 46.4 & & River & $\mathrm{N}$ & $11 / 29 / 00$ & 0.175 & 0.042 & 0.00652 & \\
\hline Uranium-238 & Rich.Pmphs HRM 46.4 & & River & $\mathrm{N}$ & $1 / 4 / 01$ & 0.171 & 0.028 & 0.00646 & \\
\hline Uranium-238 & Rich.Pmphs HRM 46.4 & & River & $\mathrm{N}$ & $1 / 31 / 01$ & 0.23 & 0.061 & 0.0297 & \\
\hline Uranium-238 & Rich.Pmphs HRM 46.4 & & River & $\mathrm{N}$ & $3 / 1 / 01$ & 0.25 & 0.04 & 0.0155 & \\
\hline Uranium-238 & Rich.Pmphs HRM 46.4 & & River & $\mathrm{N}$ & $4 / 4 / 01$ & 0.24 & 0.044 & 0.0182 & \\
\hline Uranium-238 & Rich.Pmphs HRM 46.4 & & River & $\mathrm{N}$ & $5 / 2 / 01$ & 0.305 & 0.039 & 0.00679 & \\
\hline Uranium-238 & Rich.Pmphs HRM 46.4 & & River & $\mathrm{N}$ & $5 / 30 / 01$ & 0.239 & 0.034 & 0.00332 & \\
\hline Uranium-238 & Rich.Pmphs HRM 46.4 & & River & $\mathrm{N}$ & $6 / 28 / 01$ & 0.189 & 0.038 & 0.0102 & \\
\hline Uranium-238 & Rich.Pmphs HRM 46.4 & & River & $\mathrm{N}$ & 8/9/01 & 0.215 & 0.039 & 0.0136 & \\
\hline Uranium-238 & Rich.Pmphs HRM 46.4 & & River & $\mathrm{N}$ & $9 / 5 / 01$ & 0.172 & 0.036 & 0.0104 & \\
\hline Uranium-238 & Rich.Pmphs HRM 46.4 & & River & $\mathrm{N}$ & $10 / 2 / 01$ & 0.223 & 0.044 & 0.00568 & \\
\hline Uranium-238 & Rich.Pmphs HRM 46.4 & & River & $\mathrm{N}$ & $11 / 1 / 01$ & 0.185 & 0.032 & 0.0113 & \\
\hline Uranium-238 & Rich.Pmphs HRM 46.4 & & River & $\mathrm{N}$ & $11 / 27 / 01$ & 0.221 & 0.036 & 0.0114 & \\
\hline Uranium-238 & Rich.Pmphs HRM 46.4 & & River & $\mathrm{N}$ & $1 / 3 / 02$ & 0.225 & 0.037 & 0.00822 & \\
\hline Uranium-238 & Rich.Pmphs HRM 46.4 & & River & $\mathrm{N}$ & $2 / 6 / 02$ & 0.195 & 0.032 & 0.0035 & \\
\hline Uranium-238 & Rich.Pmphs HRM 46.4 & & River & $\mathrm{N}$ & $3 / 7 / 02$ & 0.239 & 0.041 & 0.0135 & \\
\hline Uranium-238 & Rich.Pmphs HRM 46.4 & & River & $\mathrm{N}$ & $4 / 3 / 02$ & 0.26 & 0.041 & 0.0121 & \\
\hline Uranium-238 & Rich.Pmphs HRM 46.4 & & River & $\mathrm{N}$ & $5 / 1 / 02$ & 0.232 & 0.051 & 0.0213 & \\
\hline Uranium-238 & Rich.Pmphs HRM 46.4 & & River & $\mathrm{N}$ & $5 / 29 / 02$ & 0.195 & 0.032 & 0.00983 & \\
\hline Uranium-238 & Rich.Pmphs HRM 46.4 & & River & $\mathrm{N}$ & $6 / 27 / 02$ & 0.189 & 0.038 & 0.0165 & \\
\hline Uranium-238 & Rich.Pmphs HRM 46.4 & & River & $\mathrm{N}$ & $8 / 7 / 02$ & 0.195 & 0.033 & 0.00787 & \\
\hline Uranium-238 & Rich.Pmphs HRM 46.4 & & River & $\mathrm{N}$ & $9 / 4 / 02$ & 0.292 & 0.041 & 0.00389 & \\
\hline Uranium-238 & Rich.Pmphs HRM 46.4 & & River & $\mathrm{N}$ & $10 / 2 / 02$ & 0.23 & 0.036 & 0.0127 & \\
\hline Uranium-238 & Rich.Pmphs HRM 46.4 & & River & $\mathrm{N}$ & $10 / 30 / 02$ & 0.196 & 0.035 & 0.014 & \\
\hline Uranium-238 & Rich.Pmphs HRM 46.4 & & River & $\mathrm{N}$ & $11 / 26 / 02$ & 0.166 & 0.03 & 0.00346 & \\
\hline Uranium-238 & Rich.Pmphs HRM 46.4 & & River & $\mathrm{N}$ & $1 / 8 / 03$ & 0.185 & 0.032 & 0.00978 & \\
\hline Uranium-238 & Rich.Pmphs HRM 46.4 & & River & $\mathrm{N}$ & $2 / 5 / 03$ & 0.199 & 0.032 & 0.00938 & \\
\hline
\end{tabular}


Table A.4. (contd)

\begin{tabular}{|c|c|c|c|c|c|c|c|c|c|}
\hline Analyte & Location & $\begin{array}{c}\text { Sample } \\
\text { Number }\end{array}$ & \begin{tabular}{|c|} 
Sampled \\
From
\end{tabular} & \begin{tabular}{|c} 
Filter \\
Flag
\end{tabular} & $\begin{array}{c}\text { Sample } \\
\text { Date }\end{array}$ & $\begin{array}{c}\text { Value } \\
(\mathrm{pCi} / \mathrm{L})\end{array}$ & $\begin{array}{c}\text { Counting } \\
\text { Error }\end{array}$ & MDA & $\begin{array}{l}\text { Quali- } \\
\text { fier }\end{array}$ \\
\hline Uranium-238 & 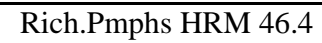 & & $\begin{array}{c}\text { River } \\
\end{array}$ & $\mathrm{N}$ & $\begin{array}{l}3 / 5 / 03 \\
\end{array}$ & 0.255 & 0.037 & 0.00357 & \\
\hline Uranium-238 & Rich.Pmphs HRM 46.4 & & River & $\mathrm{N}$ & $4 / 2 / 03$ & 0.301 & 0.044 & 0.0182 & \\
\hline Uranium-238 & Rich.Pmphs HRM 46.4 & & River & $\mathrm{N}$ & $4 / 30 / 03$ & 0.238 & 0.037 & 0.0131 & \\
\hline Uranium-238 & Rich.Pmphs HRM 46.4 & & River & $\mathrm{N}$ & $5 / 28 / 03$ & 0.18 & 0.04 & 0.0216 & \\
\hline Uranium-238 & Rich.Pmphs HRM 46.4 & & River & $\mathrm{N}$ & $7 / 10 / 03$ & 0.192 & 0.033 & 0.00383 & \\
\hline Uranium-238 & Rich.Pmphs HRM 46.4 & & River & $\mathrm{N}$ & $8 / 8 / 03$ & 0.214 & 0.039 & 0.0048 & \\
\hline Uranium-238 & Rich.Pmphs HRM 46.4 & & River & $\mathrm{N}$ & 9/3/03 & 0.232 & 0.046 & 0.0128 & \\
\hline Uranium-238 & Rich.Pmphs HRM 46.4 & & River & $\mathrm{N}$ & $9 / 30 / 03$ & 0.203 & 0.037 & 0.0216 & \\
\hline Uranium-238 & Rich.Pmphs HRM 46.4 & & River & $\mathrm{N}$ & $10 / 29 / 03$ & 0.217 & 0.046 & 0.00649 & \\
\hline Uranium-238 & Rich.Pmphs HRM 46.4 & & River & $\mathrm{N}$ & $11 / 25 / 03$ & 0.19 & 0.035 & 0.00415 & \\
\hline Uranium-238 & Rich.Pmphs HRM 46.4 & & River & $\mathrm{N}$ & $1 / 8 / 04$ & 0.227 & 0.046 & 0.00623 & \\
\hline Uranium-238 & Rich.Pmphs HRM 46.4 & & River & $\mathrm{N}$ & $2 / 4 / 04$ & 0.185 & 0.036 & 0.0046 & \\
\hline Uranium-238 & Rich.Pmphs HRM 46.4 & & River & $\mathrm{N}$ & $3 / 2 / 04$ & 0.208 & 0.036 & 0.0104 & \\
\hline Uranium-238 & Rich.Pmphs HRM 46.4 & & River & $\mathrm{N}$ & $4 / 1 / 04$ & 0.273 & 0.055 & 0.00739 & \\
\hline Uranium-238 & Rich.Pmphs HRM 46.4 & & River & $\mathrm{N}$ & $5 / 6 / 04$ & 0.209 & 0.036 & 0.0137 & \\
\hline Uranium-238 & Rich.Pmphs HRM 46.4 & & River & $\mathrm{N}$ & $6 / 8 / 04$ & 0.249 & 0.058 & 0.0392 & \\
\hline Uranium-238 & Rich.Pmphs HRM 46.4 & & River & $\mathrm{N}$ & $7 / 8 / 04$ & 0.163 & 0.038 & 0.0142 & \\
\hline Uranium-238 & Rich.Pmphs HRM 46.4 & & River & $\mathrm{N}$ & $8 / 4 / 04$ & 0.161 & 0.034 & 0.0123 & \\
\hline Uranium-238 & Rich.Pmphs HRM 46.4 & & River & $\mathrm{N}$ & $8 / 31 / 04$ & 0.164 & 0.035 & 0.0047 & \\
\hline Uranium-238 & Rich.Pmphs HRM 46.4 & & River & $\mathrm{N}$ & $10 / 1 / 04$ & 0.201 & 0.035 & 0.0166 & \\
\hline Uranium-238 & Rich.Pmphs HRM 46.4 & & River & $\mathrm{N}$ & $10 / 28 / 04$ & 0.267 & 0.058 & 0.00827 & \\
\hline Uranium-238 & Rich.Pmphs HRM 46.4 & & River & $\mathrm{N}$ & $12 / 1 / 04$ & 0.185 & 0.035 & 0.0263 & \\
\hline Uranium-238 & Rich.Pmphs HRM 46.4 & & River & $\mathrm{N}$ & $1 / 5 / 05$ & 0.195 & 0.033 & 0.00364 & \\
\hline Uranium-238 & Rich.Pmphs HRM 46.4 & & River & $\mathrm{N}$ & $2 / 3 / 05$ & 0.191 & 0.037 & 0.00459 & \\
\hline Uranium-238 & Rich.Pmphs HRM 46.4 & & River & $\mathrm{N}$ & $3 / 2 / 05$ & 0.218 & 0.039 & 0.00439 & \\
\hline Uranium-238 & Rich.Pmphs HRM 46.4 & & River & $\mathrm{N}$ & 3/31/05 & 0.171 & 0.036 & 0.0183 & \\
\hline Uranium-238 & Rich.Pmphs HRM 46.4 & & River & $\mathrm{N}$ & $5 / 3 / 05$ & 0.204 & 0.037 & 0.00914 & \\
\hline Uranium-238 & Rich.Pmphs HRM 46.4 & & River & $\mathrm{N}$ & $6 / 9 / 05$ & 0.181 & 0.032 & 0.00368 & \\
\hline Uranium-238 & Rich.Pmphs HRM 46.4 & & River & $\mathrm{N}$ & $7 / 7 / 05$ & 0.205 & 0.033 & 0.0117 & \\
\hline Uranium-238 & Rich.Pmphs HRM 46.4 & & River & $\mathrm{N}$ & $8 / 4 / 05$ & 0.193 & 0.033 & 0.00753 & \\
\hline Uranium-238 & Rich.Pmphs HRM 46.4 & & River & $\mathrm{N}$ & $8 / 31 / 05$ & 0.157 & 0.031 & 0.0152 & \\
\hline Uranium-238 & Rich.Pmphs HRM 46.4 & & River & $\mathrm{N}$ & 9/29/05 & 0.181 & 0.035 & 0.0116 & \\
\hline Uranium-238 & 300 Area & B0R233 & Drinking & $\mathrm{N}$ & $12 / 30 / 98$ & 0.95 & 0.094 & 0.00623 & $\mathrm{~J}$ \\
\hline Uranium-238 & 331 Bldg. 300 Area & B0HRH1 & Drinking & $\mathrm{N}$ & $4 / 15 / 96$ & 0.0681 & 0.0264 & & \\
\hline Uranium-238 & 300 Spr DR 9 -4 & B12T19 & River & $\mathrm{N}$ & $8 / 27 / 01$ & 0.254 & 0.037 & 0.00919 & \\
\hline Uranium-238 & 300 Spr DR 9 -3 & B12RV9 & River & $\mathrm{N}$ & $8 / 27 / 01$ & 1.57 & 0.092 & 0.0076 & \\
\hline Uranium-238 & 300 Spr DR 9 -2 & B12RV7 & River & $\mathrm{N}$ & $8 / 27 / 01$ & 4.62 & 0.17 & 0.0128 & \\
\hline Uranium-238 & 300 Spr DR 9 -1 & B12RV5 & River & $\mathrm{N}$ & $8 / 27 / 01$ & 4.26 & 0.16 & 0.00797 & \\
\hline Uranium-238 & 300 Spr DR 7 -4 & B12T15 & River & $\mathrm{N}$ & $8 / 27 / 01$ & 0.255 & 0.04 & 0.00415 & \\
\hline Uranium-238 & 300 Spr DR 7 -3 & B12RT5 & River & $\mathrm{N}$ & $8 / 27 / 01$ & 0.354 & 0.045 & 0.00946 & \\
\hline Uranium-238 & 300 Spr DR 7 -2 & B12RT3 & River & $\mathrm{N}$ & $8 / 27 / 01$ & 0.482 & 0.051 & 0.00746 & \\
\hline Uranium-238 & 300 Spr DR 7 -1 & B12RT1 & River & $\mathrm{N}$ & 8/27/01 & 1.27 & 0.084 & 0.00947 & \\
\hline Uranium-238 & 300 Spr DR $11-4$ & B12T23 & River & $\mathrm{N}$ & $8 / 27 / 01$ & 0.287 & 0.046 & 0.0104 & \\
\hline Uranium-238 & 300 Spr DR $11-3$ & B12RX5 & River & $\mathrm{N}$ & $8 / 27 / 01$ & 0.437 & 0.06 & 0.0113 & \\
\hline Uranium-238 & 300 Spr DR $11-2$ & B12RX3 & River & $\mathrm{N}$ & $8 / 27 / 01$ & 0.609 & 0.059 & 0.00385 & \\
\hline Uranium-238 & 300 Spr DR 11 -1 & B12RX1 & River & $\mathrm{N}$ & $8 / 27 / 01$ & 2.48 & 0.12 & 0.00404 & \\
\hline Uranium-238 & 300 Spr 9 THRU Spr 11 & B12RW1 & River & $\mathrm{N}$ & $8 / 27 / 01$ & 0.542 & 0.055 & 0.00373 & \\
\hline Uranium-238 & 300 Spr $9-4$ & B12T17 & River & $\mathrm{N}$ & $8 / 27 / 01$ & 0.222 & 0.041 & 0.016 & \\
\hline Uranium-238 & 300 Spr $9-3$ & B12RV3 & River & $\mathrm{N}$ & $8 / 27 / 01$ & 0.348 & 0.05 & 0.00486 & \\
\hline Uranium-238 & 300 Spr $9-2$ & B12RV1 & River & $\mathrm{N}$ & $8 / 27 / 01$ & 1.17 & 0.1 & 0.0121 & \\
\hline
\end{tabular}


Table A.4. (contd)

\begin{tabular}{|c|c|c|c|c|c|c|c|c|c|}
\hline Analyte & Location & $\begin{array}{c}\text { Sample } \\
\text { Number }\end{array}$ & \begin{tabular}{|c|} 
Sampled \\
From
\end{tabular} & $\begin{array}{c}\text { Filter } \\
\text { Flag }\end{array}$ & $\begin{array}{c}\text { Sample } \\
\text { Date }\end{array}$ & $\begin{array}{c}\text { Value } \\
(\mathrm{pCi} / \mathrm{L})\end{array}$ & $\begin{array}{c}\text { Counting } \\
\text { Error }\end{array}$ & MDA & $\begin{array}{l}\text { Quali- } \\
\text { fier }\end{array}$ \\
\hline Uranium-238 & 300 Spr 9 -1 & B12RT9 & $\begin{array}{l}\text { River } \\
\end{array}$ & $\overline{\mathbf{N}}$ & 8/27/01 & 27.8 & $\begin{array}{lll}0.4 & \end{array}$ & 0.00828 & \\
\hline Uranium-238 & 300 Spr 7 THRU Spr 9 & B12RT7 & River & $\mathrm{N}$ & $8 / 27 / 01$ & 0.374 & 0.049 & 0.00424 & \\
\hline Uranium-238 & 300 Spr $7-4$ & B12T13 & River & $\mathrm{N}$ & $8 / 27 / 01$ & 0.378 & 0.048 & 0.00401 & \\
\hline Uranium-238 & 300 Spr $7-3$ & B12RR9 & River & $\mathrm{N}$ & $8 / 27 / 01$ & 0.442 & 0.048 & 0.00727 & \\
\hline Uranium-238 & 300 Spr $7-2$ & B12RR7 & River & $\mathrm{N}$ & $8 / 27 / 01$ & 1.56 & 0.096 & 0.00394 & \\
\hline Uranium-238 & 300 Spr 7 -1 & B12RR5 & River & $\mathrm{N}$ & $8 / 27 / 01$ & 4.85 & 0.17 & 0.0123 & \\
\hline Uranium-238 & 300 Spr $14-4$ & B12T25 & River & $\mathrm{N}$ & $8 / 27 / 01$ & 0.278 & 0.04 & 0.00384 & \\
\hline Uranium-238 & 300 Spr $14-3$ & B12RY3 & River & $\mathrm{N}$ & $8 / 27 / 01$ & 0.407 & 0.049 & 0.0125 & \\
\hline Uranium-238 & 300 Spr $14-2$ & B12RY1 & River & $\mathrm{N}$ & $8 / 27 / 01$ & 0.433 & 0.05 & 0.00797 & \\
\hline Uranium-238 & 300 Spr $14-1$ & B12RX9 & River & $\mathrm{N}$ & $8 / 27 / 01$ & 0.454 & 0.058 & 0.0178 & \\
\hline Uranium-238 & 300 Spr $11-4$ & B12T21 & River & $\mathrm{N}$ & $8 / 27 / 01$ & 0.639 & 0.061 & 0.00385 & \\
\hline Uranium-238 & 300 Spr $11-3$ & B12RW9 & River & $\mathrm{N}$ & $8 / 27 / 01$ & 1.28 & 0.082 & 0.00896 & \\
\hline Uranium-238 & 300 Spr $11-2$ & B12RW7 & River & $\mathrm{N}$ & $8 / 27 / 01$ & 0.627 & 0.058 & 0.00748 & \\
\hline Uranium-238 & 300 Spr 11 -1 & B12RW5 & River & $\mathrm{N}$ & $8 / 27 / 01$ & 4.48 & 0.15 & 0.0101 & \\
\hline Uranium-238 & 300 Area-10 HRM 43.1 & B0C5C6 & River & $\mathrm{N}$ & 8/26/94 & 0.185 & 0.116 & & \\
\hline Uranium-238 & 300 Area-10 HRM 43.1 & B0G8B2 & River & $\mathrm{N}$ & 9/18/95 & 0.27 & 0.056 & & \\
\hline Uranium-238 & 300 Area-10 HRM 43.1 & B0J8Y6 & River & $\mathrm{N}$ & 9/20/96 & 0.4 & 0.0638 & & \\
\hline Uranium-238 & 300 Area-10 HRM 43.1 & B0LVW6 & River & $\mathrm{N}$ & 8/25/97 & 0.417 & 0.0582 & & \\
\hline Uranium-238 & 300 Area-10 HRM 43.1 & B0PVR3 & River & $\mathrm{N}$ & 9/15/98 & 0.318 & 0.0942 & & \\
\hline Uranium-238 & 300 Area-10 HRM 43.1 & B0WB28 & River & $\mathrm{N}$ & 9/16/99 & 0.305 & 0.046 & 0.0136 & \\
\hline Uranium-238 & 300 Area-10 HRM 43.1 & B106Y3 & River & $\mathrm{N}$ & $9 / 19 / 00$ & 0.246 & 0.04 & 0.0046 & \\
\hline Uranium-238 & 300 Area-10 HRM 43.1 & B12TC6 & River & $\mathrm{N}$ & 9/13/01 & 0.787 & 0.069 & 0.00844 & \\
\hline Uranium-238 & 300 Area-10 HRM 43.1 & B158M0 & River & $\mathrm{N}$ & $9 / 10 / 02$ & 0.3 & 0.049 & 0.0151 & \\
\hline Uranium-238 & 300 Area-10 HRM 43.1 & B17CK0 & River & $\mathrm{N}$ & $9 / 9 / 03$ & 0.355 & 0.051 & 0.0138 & \\
\hline Uranium-238 & 300 Area-10 HRM 43.1 & B1B725 & River & $\mathrm{N}$ & 9/15/04 & 0.782 & 0.079 & 0.00537 & \\
\hline Uranium-238 & 300 Area-10 HRM 43.1 & & River & $\mathrm{N}$ & 9/15/05 & 0.447 & 0.058 & 0.0168 & \\
\hline Uranium-238 & 300 Area SPRING 42-2 & & River & $\mathrm{N}$ & 9/15/05 & 0.219 & 0.041 & 0.0194 & \\
\hline Uranium-238 & 300 Area Spr DR 42-2 & & River & $\mathrm{N}$ & $9 / 15 / 05$ & 0.22 & 0.06 & 0.03 & \\
\hline Uranium-238 & 300 Area Shr HRM42.9 & B0WB56 & River & $\mathrm{N}$ & 9/16/99 & 0.165 & 0.035 & 0.0236 & \\
\hline Uranium-238 & 300 Area Shr HRM42.9 & B10782 & River & $\mathrm{N}$ & $9 / 19 / 00$ & 0.21 & 0.035 & 0.00405 & \\
\hline Uranium-238 & 300 Area Shr HRM42.9 & B12TR6 & River & $\mathrm{N}$ & 9/13/01 & 0.213 & 0.035 & 0.00954 & \\
\hline Uranium-238 & 300 Area Shr HRM42.9 & B158Y9 & River & $\mathrm{N}$ & $9 / 10 / 02$ & 0.177 & 0.048 & 0.0277 & \\
\hline Uranium-238 & 300 Area Shr HRM42.9 & B17CX7 & River & $\mathrm{N}$ & $9 / 9 / 03$ & 0.508 & 0.052 & 0.0035 & \\
\hline Uranium-238 & 300 Area Shr HRM42.9 & B1B7C7 & River & $\mathrm{N}$ & 9/15/04 & 0.238 & 0.04 & 0.00427 & \\
\hline Uranium-238 & 300 Area Shr HRM42.9 & & River & $\mathrm{N}$ & 9/15/05 & 0.185 & 0.038 & 0.0125 & \\
\hline Uranium-238 & 300 Area Shr HRM42.5 & B0WB55 & River & $\mathrm{N}$ & 9/16/99 & 0.226 & 0.04 & 0.0172 & \\
\hline Uranium-238 & 300 Area Shr HRM42.5 & B10779 & River & $\mathrm{N}$ & 9/19/00 & 0.187 & 0.031 & 0.00911 & \\
\hline Uranium-238 & 300 Area Shr HRM42.5 & B12TR2 & River & $\mathrm{N}$ & 9/13/01 & 0.2 & 0.037 & 0.00452 & \\
\hline Uranium-238 & 300 Area Shr HRM42.5 & B158Y6 & River & $\mathrm{N}$ & $9 / 10 / 02$ & 0.183 & 0.032 & 0.00358 & \\
\hline Uranium-238 & 300 Area Shr HRM42.5 & B17CX3 & River & $\mathrm{N}$ & $\begin{array}{l}9 / 9 / 03 \\
\end{array}$ & 6.19 & 0.17 & 0.0195 & \\
\hline Uranium-238 & 300 Area Shr HRM42.4 & B1B7H3 & River & $\mathrm{N}$ & 9/15/04 & 0.26 & 0.047 & 0.00541 & \\
\hline Uranium-238 & 300 Area Shr HRM42.1 & B0WB54 & River & $\mathrm{N}$ & 9/16/99 & 0.203 & 0.037 & 0.0233 & \\
\hline Uranium-238 & 300 Area Shr HRM42.1 & B10776 & River & $\mathrm{N}$ & 9/19/00 & 0.244 & 0.034 & 0.00669 & \\
\hline Uranium-238 & 300 Area Shr HRM42.1 & B12TP8 & River & $\mathrm{N}$ & 9/13/01 & 0.293 & 0.041 & 0.00787 & \\
\hline Uranium-238 & 300 Area Shr HRM42.1 & B158Y3 & River & $\mathrm{N}$ & $9 / 10 / 02$ & 0.162 & 0.032 & 0.0135 & \\
\hline Uranium-238 & 300 Area Shr HRM42.1 & B17CW9 & River & $\mathrm{N}$ & $9 / 9 / 03$ & 0.354 & 0.044 & 0.00364 & \\
\hline Uranium-238 & 300 Area Shr HRM42.1 & B1B7C3 & River & $\mathrm{N}$ & $9 / 15 / 04$ & 0.254 & 0.045 & 0.017 & \\
\hline Uranium-238 & 300 Area Shr HRM41.5 & B0WB53 & River & $\mathrm{N}$ & 9/16/99 & 0.203 & 0.04 & 0.033 & \\
\hline Uranium-238 & 300 Area Shr HRM41.5 & B10773 & River & $\mathrm{N}$ & $9 / 19 / 00$ & 0.162 & 0.033 & 0.01 & \\
\hline Uranium-238 & 300 Area Shr HRM41.5 & B12TP4 & River & $\mathrm{N}$ & $9 / 13 / 01$ & 0.197 & 0.041 & 0.0139 & \\
\hline
\end{tabular}


Table A.4. (contd)

\begin{tabular}{|c|c|c|c|c|c|c|c|c|c|}
\hline Analyte & Location & $\begin{array}{l}\text { Sample } \\
\text { Number }\end{array}$ & $\begin{array}{c}\text { Sampled } \\
\text { From }\end{array}$ & \begin{tabular}{|c|} 
Filter \\
Flag
\end{tabular} & $\begin{array}{l}\text { Sample } \\
\text { Date }\end{array}$ & $\begin{array}{c}\text { Value } \\
(\mathrm{pCi} / \mathrm{L})\end{array}$ & $\begin{array}{c}\text { Counting } \\
\text { Error }\end{array}$ & MDA & $\begin{array}{l}\text { Quali- } \\
\text { fier }\end{array}$ \\
\hline Uranium-238 & 300 Area Shr HRM41.5 & B158Y0 & $\begin{array}{ll}\text { River } \\
\end{array}$ & $\mathrm{N}$ & $\begin{array}{l}9 / 10 / 02 \\
\end{array}$ & $\begin{array}{c}0.151 \\
\end{array}$ & 0.033 & $\begin{array}{ll}0.0128 \\
\end{array}$ & \\
\hline Uranium-238 & 300 Area Shr HRM41.5 & B17CW5 & River & $\mathrm{N}$ & 9/9/03 & 0.21 & 0.034 & 0.0036 & \\
\hline Uranium-238 & 300 Area Shr HRM41.5 & B1B7B9 & River & $\mathrm{N}$ & 9/15/04 & 0.175 & 0.045 & 0.0193 & \\
\hline Uranium-238 & 300 Area Shr HRM41.5 & & River & $\mathrm{N}$ & 9/15/05 & 0.202 & 0.035 & 0.00392 & \\
\hline Uranium-238 & 300 Area Outfl13 & B19JC4 & River & $\mathrm{N}$ & $6 / 24 / 04$ & 4.06 & 0.19 & 0.0261 & \\
\hline Uranium-238 & 300 Area Outfl13 & B1B7H7 & River & $\mathrm{N}$ & 9/15/04 & 4.14 & 0.18 & 0.0136 & \\
\hline Uranium-238 & 300 Area Outfl13 & B1BW54 & River & $\mathrm{N}$ & $12 / 19 / 04$ & 3.1 & 0.14 & 0.0184 & \\
\hline Uranium-238 & 300 Area Outfl13 & & River & $\mathrm{N}$ & $6 / 7 / 05$ & 5.05 & 0.16 & 0.0187 & \\
\hline Uranium-238 & 300 Area Outfl13 & & River & $\mathrm{N}$ & 9/15/05 & 4.06 & 0.19 & 0.00627 & \\
\hline Uranium-238 & 300 Area -9 HRM 43.1 & B0C5C5 & River & $\mathrm{N}$ & $8 / 26 / 94$ & 0.284 & 0.148 & & \\
\hline Uranium-238 & 300 Area -9 HRM 43.1 & B0G8B1 & River & $\mathrm{N}$ & 9/18/95 & 0.202 & 0.0447 & & \\
\hline Uranium-238 & 300 Area -9 HRM 43.1 & B0J8Y5 & River & $\mathrm{N}$ & 9/20/96 & 0.244 & 0.0477 & & \\
\hline Uranium-238 & 300 Area -9 HRM 43.1 & B0LVW5 & River & $\mathrm{N}$ & $8 / 25 / 97$ & 0.203 & 0.04 & & \\
\hline Uranium-238 & 300 Area -8 HRM 43.1 & B0C5C4 & River & $\mathrm{N}$ & $8 / 26 / 94$ & 0.116 & 0.0666 & & \\
\hline Uranium-238 & 300 Area -8 HRM 43.1 & B0G8B0 & River & $\mathrm{N}$ & 9/18/95 & 0.201 & 0.0436 & & \\
\hline Uranium-238 & 300 Area -8 HRM 43.1 & B0J8Y4 & River & $\mathrm{N}$ & 9/20/96 & 0.206 & 0.0425 & & \\
\hline Uranium-238 & 300 Area -8 HRM 43.1 & B0LVW4 & River & $\mathrm{N}$ & $8 / 25 / 97$ & 0.258 & 0.0451 & & \\
\hline Uranium-238 & 300 Area -8 HRM 43.1 & B0PVR1 & River & $\mathrm{N}$ & 9/15/98 & 0.195 & 0.047 & & \\
\hline Uranium-238 & 300 Area -7 HRM 43.1 & B0C5C3 & River & $\mathrm{N}$ & $8 / 26 / 94$ & 0.186 & 0.0804 & & \\
\hline Uranium-238 & 300 Area -7 HRM 43.1 & B0G899 & River & $\mathrm{N}$ & 9/18/95 & 0.236 & 0.0489 & & \\
\hline Uranium-238 & 300 Area -7 HRM 43.1 & B0J8Y3 & River & $\mathrm{N}$ & 9/20/96 & 0.274 & 0.0581 & & \\
\hline Uranium-238 & 300 Area -7 HRM 43.1 & B0LVW3 & River & $\mathrm{N}$ & $8 / 25 / 97$ & 0.224 & 0.0443 & & \\
\hline Uranium-238 & 300 Area -7 HRM 43.1 & B0PVR0 & River & $\mathrm{N}$ & 9/15/98 & 0.164 & 0.0861 & & \\
\hline Uranium-238 & 300 Area -7 HRM 43.1 & B0WB27 & River & $\mathrm{N}$ & 9/16/99 & 0.204 & 0.037 & 0.0131 & \\
\hline Uranium-238 & 300 Area -7 HRM 43.1 & B106Y1 & River & $\mathrm{N}$ & 9/19/00 & 0.202 & 0.038 & 0.0158 & \\
\hline Uranium-238 & 300 Area -7 HRM 43.1 & B12TC4 & River & $\mathrm{N}$ & 9/13/01 & 0.184 & 0.033 & 0.00394 & \\
\hline Uranium-238 & 300 Area -7 HRM 43.1 & B158L9 & River & $\mathrm{N}$ & 9/10/02 & 0.201 & 0.041 & 0.00542 & \\
\hline Uranium-238 & 300 Area -7 HRM 43.1 & B17CJ8 & River & $\mathrm{N}$ & 9/9/03 & 0.204 & 0.034 & 0.00383 & \\
\hline Uranium-238 & 300 Area -7 HRM 43.1 & B1B724 & River & $\mathrm{N}$ & 9/15/04 & 0.249 & 0.051 & 0.0257 & \\
\hline Uranium-238 & 300 Area -7 HRM 43.1 & & River & $\mathrm{N}$ & 9/15/05 & 0.174 & 0.048 & 0.046 & \\
\hline Uranium-238 & 300 Area -6 HRM 43.1 & B0C5C2 & River & $\mathrm{N}$ & $8 / 26 / 94$ & 0.181 & 0.0777 & & \\
\hline Uranium-238 & 300 Area -6 HRM 43.1 & B0G898 & River & $\mathrm{N}$ & 9/18/95 & 0.224 & 0.0458 & & \\
\hline Uranium-238 & 300 Area -6 HRM 43.1 & B0J8Y2 & River & $\mathrm{N}$ & 9/20/96 & 0.231 & 0.0484 & & \\
\hline Uranium-238 & 300 Area -6 HRM 43.1 & B0LVW2 & River & $\mathrm{N}$ & $8 / 25 / 97$ & 0.19 & 0.0373 & & \\
\hline Uranium-238 & 300 Area -5 HRM 43.1 & B0C5C1 & River & $\mathrm{N}$ & 8/26/94 & 0.15 & 0.0557 & & \\
\hline Uranium-238 & 300 Area -5 HRM 43.1 & B0G897 & River & $\mathrm{N}$ & 9/18/95 & 0.19 & 0.0479 & & \\
\hline Uranium-238 & 300 Area -5 HRM 43.1 & B0J8Y0 & River & $\mathrm{N}$ & 9/20/96 & 0.202 & 0.0399 & & \\
\hline Uranium-238 & 300 Area -5 HRM 43.1 & B0LVW1 & River & $\mathrm{N}$ & $8 / 25 / 97$ & 0.191 & 0.0402 & & \\
\hline Uranium-238 & 300 Area -5 HRM 43.1 & B0PVP8 & River & $\mathrm{N}$ & 9/15/98 & 0.167 & 0.0407 & & \\
\hline Uranium-238 & 300 Area -5 HRM 43.1 & B0WB26 & River & $\mathrm{N}$ & 9/16/99 & 0.178 & 0.037 & 0.025 & \\
\hline Uranium-238 & 300 Area -5 HRM 43.1 & B106X9 & River & $\mathrm{N}$ & $9 / 19 / 00$ & 0.165 & 0.036 & 0.0172 & \\
\hline Uranium-238 & 300 Area -5 HRM 43.1 & B12TC2 & River & $\mathrm{N}$ & 9/13/01 & 0.213 & 0.036 & 0.00393 & \\
\hline Uranium-238 & 300 Area -5 HRM 43.1 & B158L8 & River & $\mathrm{N}$ & 9/10/02 & 0.167 & 0.033 & 0.0213 & \\
\hline Uranium-238 & 300 Area -5 HRM 43.1 & B17CJ6 & River & $\mathrm{N}$ & 9/9/03 & 0.189 & 0.036 & 0.014 & \\
\hline Uranium-238 & 300 Area -5 HRM 43.1 & B1B723 & River & $\mathrm{N}$ & 9/15/04 & 0.211 & 0.047 & 0.028 & \\
\hline Uranium-238 & 300 Area -5 HRM 43.1 & & River & $\mathrm{N}$ & $9 / 15 / 05$ & 0.165 & 0.032 & 0.0108 & \\
\hline Uranium-238 & 300 Area -4 HRM 43.1 & B0C5C0 & River & $\mathrm{N}$ & $8 / 26 / 94$ & 0.143 & 0.0685 & & \\
\hline Uranium-238 & 300 Area -4 HRM 43.1 & B0G896 & River & $\mathrm{N}$ & 9/18/95 & 0.174 & 0.0394 & & \\
\hline Uranium-238 & 300 Area -4 HRM 43.1 & B0J8X8 & River & $\mathrm{N}$ & 9/20/96 & 0.187 & 0.0423 & & \\
\hline Uranium-238 & 300 Area -4 HRM 43.1 & B0LVW0 & River & $\mathrm{N}$ & $8 / 25 / 97$ & 0.187 & 0.0394 & & \\
\hline
\end{tabular}


Table A.4. (contd)

\begin{tabular}{|c|c|c|c|c|c|c|c|c|c|}
\hline Analyte & Location & $\begin{array}{c}\text { Sample } \\
\text { Number }\end{array}$ & \begin{tabular}{|c|} 
Sampled \\
From
\end{tabular} & \begin{tabular}{|l} 
Filter \\
Flag
\end{tabular} & $\begin{array}{c}\text { Sample } \\
\text { Date }\end{array}$ & $\begin{array}{c}\text { Value } \\
(\mathrm{pCi} / \mathrm{L})\end{array}$ & $\begin{array}{c}\text { Counting } \\
\text { Error }\end{array}$ & MDA & $\begin{array}{l}\text { Quali- } \\
\text { fier }\end{array}$ \\
\hline Uranium-238 & 300 Area -4 HRM 43.1 & B0PVP7 & $\begin{array}{l}\text { River } \\
\end{array}$ & $\mathrm{N}$ & 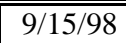 & $\begin{array}{c}0.18 \\
\end{array}$ & 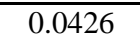 & & \\
\hline Uranium-238 & 300 Area -3 HRM 43.1 & B0C5B9 & River & $\mathrm{N}$ & $8 / 26 / 94$ & 0.287 & 0.188 & & \\
\hline Uranium-238 & 300 Area -3 HRM 43.1 & B0G895 & River & $\mathrm{N}$ & 9/18/95 & 0.139 & 0.0352 & & \\
\hline Uranium-238 & 300 Area -3 HRM 43.1 & B0J8X6 & River & $\mathrm{N}$ & 9/20/96 & 0.177 & 0.0404 & & \\
\hline Uranium-238 & 300 Area -3 HRM 43.1 & B0LVV9 & River & $\mathrm{N}$ & $8 / 25 / 97$ & 0.221 & 0.044 & & \\
\hline Uranium-238 & 300 Area -3 HRM 43.1 & B0PVP6 & River & $\mathrm{N}$ & 9/15/98 & 0.0958 & 0.0577 & & \\
\hline Uranium-238 & 300 Area -3 HRM 43.1 & B0WB25 & River & $\mathrm{N}$ & 9/16/99 & 0.157 & 0.033 & 0.0193 & \\
\hline Uranium-238 & 300 Area -3 HRM 43.1 & B106X7 & River & $\mathrm{N}$ & 9/19/00 & 0.161 & 0.028 & 0.00352 & \\
\hline Uranium-238 & 300 Area -3 HRM 43.1 & B12TC0 & River & $\mathrm{N}$ & 9/13/01 & 0.161 & 0.03 & 0.0036 & \\
\hline Uranium-238 & 300 Area -3 HRM 43.1 & B158L7 & River & $\mathrm{N}$ & $9 / 10 / 02$ & 0.158 & 0.03 & 0.00917 & \\
\hline Uranium-238 & 300 Area -3 HRM 43.1 & B17CJ4 & River & $\mathrm{N}$ & 9/9/03 & 0.22 & 0.038 & 0.0115 & \\
\hline Uranium-238 & 300 Area -3 HRM 43.1 & B1B722 & River & $\mathrm{N}$ & $9 / 15 / 04$ & 0.161 & 0.042 & 0.00683 & \\
\hline Uranium-238 & 300 Area -3 HRM 43.1 & & River & $\mathrm{N}$ & 9/15/05 & 0.163 & 0.045 & 0.0397 & \\
\hline Uranium-238 & 300 Area -2 HRM 43.1 & B0C5B8 & River & $\mathrm{N}$ & $8 / 26 / 94$ & 0.152 & 0.0861 & & \\
\hline Uranium-238 & 300 Area -2 HRM 43.1 & B0G894 & River & $\mathrm{N}$ & 9/18/95 & 0.167 & 0.0449 & & \\
\hline Uranium-238 & 300 Area -2 HRM 43.1 & B0J8X4 & River & $\mathrm{N}$ & 9/20/96 & 0.304 & 0.0532 & & \\
\hline Uranium-238 & 300 Area -2 HRM 43.1 & B0LVV8 & River & $\mathrm{N}$ & $8 / 25 / 97$ & 0.166 & 0.0373 & & \\
\hline Uranium-238 & 300 Area -2 HRM 43.1 & B0PVP5 & River & $\mathrm{N}$ & 9/15/98 & 0.15 & 0.0435 & & \\
\hline Uranium-238 & 300 Area -2 HRM 43.1 & B0WB24 & River & $\mathrm{N}$ & 9/16/99 & 0.175 & 0.039 & 0.0408 & \\
\hline Uranium-238 & 300 Area -2 HRM 43.1 & B106X5 & River & $\mathrm{N}$ & $9 / 19 / 00$ & 0.174 & 0.03 & 0.00364 & \\
\hline Uranium-238 & 300 Area -2 HRM 43.1 & B12TB8 & River & $\mathrm{N}$ & 9/13/01 & 0.191 & 0.033 & 0.00767 & \\
\hline Uranium-238 & 300 Area -2 HRM 43.1 & B158L6 & River & $\mathrm{N}$ & $9 / 10 / 02$ & 0.166 & 0.03 & 0.00871 & \\
\hline Uranium-238 & 300 Area -2 HRM 43.1 & B17CJ2 & River & $\mathrm{N}$ & $9 / 9 / 03$ & 0.206 & 0.037 & 0.0118 & \\
\hline Uranium-238 & 300 Area -2 HRM 43.1 & B1B721 & River & $\mathrm{N}$ & 9/15/04 & 0.154 & 0.039 & 0.0204 & \\
\hline Uranium-238 & 300 Area -2 HRM 43.1 & & River & $\mathrm{N}$ & 9/15/05 & 0.158 & 0.033 & 0.0142 & \\
\hline Uranium-238 & 300 Area -1 HRM 43.1 & B0C5B7 & River & $\mathrm{N}$ & $8 / 26 / 94$ & 0.156 & 0.14 & & \\
\hline Uranium-238 & 300 Area -1 HRM 43.1 & B0G893 & River & $\mathrm{N}$ & 9/18/95 & 0.246 & 0.0467 & & \\
\hline Uranium-238 & 300 Area -1 HRM 43.1 & B0J8X2 & River & $\mathrm{N}$ & 9/20/96 & 0.494 & 0.061 & & \\
\hline Uranium-238 & 300 Area -1 HRM 43.1 & B0LVV7 & River & $\mathrm{N}$ & $8 / 25 / 97$ & 0.209 & 0.0401 & & \\
\hline Uranium-238 & 300 Area -1 HRM 43.1 & B0PVP4 & River & $\mathrm{N}$ & $9 / 15 / 98$ & 0.166 & 0.0406 & & \\
\hline Uranium-238 & 300 Area -1 HRM 43.1 & B0WB23 & River & $\mathrm{N}$ & 9/16/99 & 0.144 & 0.034 & 0.0198 & \\
\hline Uranium-238 & 300 Area -1 HRM 43.1 & B106X3 & River & $\mathrm{N}$ & $9 / 19 / 00$ & 0.168 & 0.028 & 0.00325 & \\
\hline Uranium-238 & 300 Area -1 HRM 43.1 & B12TB6 & River & $\mathrm{N}$ & 9/13/01 & 0.216 & 0.034 & 0.00351 & \\
\hline Uranium-238 & 300 Area -1 HRM 43.1 & B158L5 & River & $\mathrm{N}$ & $9 / 10 / 02$ & 0.154 & 0.029 & 0.00925 & \\
\hline Uranium-238 & 300 Area -1 HRM 43.1 & B17CJ0 & River & $\mathrm{N}$ & $\begin{array}{l}9 / 9 / 03 \\
\end{array}$ & 0.403 & 0.049 & 0.0189 & \\
\hline Uranium-238 & 300 Area -1 HRM 43.1 & B1B720 & River & $\mathrm{N}$ & 9/15/04 & 0.207 & 0.05 & 0.0209 & \\
\hline Uranium-238 & 300 Area -1 HRM 43.1 & & River & $\mathrm{N}$ & 9/15/05 & 0.142 & 0.039 & 0.0218 & \\
\hline Uranium-238 & 300 Area & B09QT2 & Drinking & $\mathrm{N}$ & $3 / 29 / 94$ & 0.316 & 0.0564 & & \\
\hline Uranium-238 & 300 Area & B0BP89 & Drinking & $\mathrm{N}$ & $6 / 21 / 94$ & 0.279 & 0.0463 & & \\
\hline Uranium-238 & 300 Area & B0C477 & Drinking & $\mathrm{N}$ & $10 / 11 / 94$ & 0.431 & 0.0635 & & \\
\hline Uranium-238 & 300 Area & B0D0Y8 & Drinking & $\mathrm{N}$ & $1 / 3 / 95$ & 0.449 & 0.0721 & & \\
\hline Uranium-238 & 300 Area & B0DKB6 & Drinking & $\mathrm{N}$ & $3 / 27 / 95$ & 0.327 & 0.0767 & & \\
\hline Uranium-238 & 300 Area & B0F909 & Drinking & $\mathrm{N}$ & $6 / 20 / 95$ & 0.238 & 0.0447 & & \\
\hline Uranium-238 & 300 Area & B0G537 & Drinking & $\mathrm{N}$ & $10 / 10 / 95$ & 0.374 & 0.06 & & \\
\hline Uranium-238 & 300 Area & B0GML6 & Drinking & $\mathrm{N}$ & $1 / 4 / 96$ & 0.31 & 0.0492 & & \\
\hline Uranium-238 & 300 Area & B0H524 & Drinking & $\mathrm{N}$ & $3 / 27 / 96$ & 0.23 & 0.0444 & & \\
\hline Uranium-238 & 300 Area & B0HPT1 & Drinking & $\mathrm{N}$ & $6 / 19 / 96$ & 0.255 & 0.0496 & & \\
\hline Uranium-238 & 300 Area & B0J464 & Drinking & $\mathrm{N}$ & $10 / 9 / 96$ & 0.55 & 0.0734 & & \\
\hline Uranium-238 & 300 Area & B0JFJ4 & Drinking & $\mathrm{N}$ & $1 / 6 / 97$ & 0.448 & 0.123 & & \\
\hline Uranium-238 & 300 Area & B0JV31 & Drinking & $\mathrm{N}$ & $3 / 25 / 97$ & 0.621 & 0.105 & & \\
\hline
\end{tabular}


Table A.4. (contd)

\begin{tabular}{|c|c|c|c|c|c|c|c|c|c|}
\hline Analyte & Location & $\begin{array}{l}\text { Sample } \\
\text { Number }\end{array}$ & $\begin{array}{l}\text { Sampled } \\
\text { From }\end{array}$ & $\begin{array}{l}\text { Filter } \\
\text { Flag }\end{array}$ & $\begin{array}{l}\text { Sample } \\
\text { Date }\end{array}$ & $\begin{array}{c}\text { Value } \\
(\mathrm{pCi} / \mathrm{L})\end{array}$ & $\begin{array}{c}\text { Counting } \\
\text { Error }\end{array}$ & MDA & $\begin{array}{c}\text { Quali- } \\
\text { fier }\end{array}$ \\
\hline "Uranium-238 & 300 Area & B0K6X1 & Drinking & $\mathrm{N}$ & $7 / 17 / 97$ & "0.289 & 0.0482 & & \\
\hline Uranium-238 & 300 Area & B0LHF7 & Drinking & $\mathrm{N}$ & $10 / 8 / 97$ & 0.72 & 0.0845 & & \\
\hline Uranium-238 & 300 Area & S0LWT9 & Drinking & $\mathrm{N}$ & $12 / 30 / 97$ & 0.776 & 0.08 & & \\
\hline Uranium-238 & 300 Area & B0MTB2 & Drinking & $\mathrm{N}$ & $3 / 27 / 98$ & 0.672 & 0.0802 & & \\
\hline Uranium-238 & 300 Area & B0NHR3 & Drinking & $\mathrm{N}$ & $7 / 15 / 98$ & 0.279 & 0.0475 & & \\
\hline Uranium-238 & 300 Area & B0P8V0 & Drinking & $\mathrm{N}$ & $10 / 8 / 98$ & 1.29 & 0.11 & 0.0199 & \\
\hline Uranium-238 & 300 Area & B19HD4 & River & $\mathrm{N}$ & $6 / 10 / 04$ & 0.17 & 0.04 & 0.0201 & \\
\hline Uranium-238 & 300 Area & B1BCB0 & River & $\mathrm{N}$ & 9/24/04 & 0.174 & 0.035 & 0.0146 & \\
\hline Uranium-238 & 300 Area & & River & $\mathrm{N}$ & $9 / 15 / 05$ & 0.168 & 0.035 & 0.0209 & \\
\hline
\end{tabular}

\section{A.2 Pore Water Data}

Samples were collected from drive points and aquifer tubes for the analytes tritium, nitrate, uranium, uranium-234, uranium-235, and uranium-238. Because the plots of the data show no difference between the aquifer tube and drive point data, all of the data were used to calculate the summary statistics for pore water.

\section{A.2.1 Uranium Pore Water Data}

Both filtered and unfiltered aquifer tube and drive point data were collected for uranium at the 300 Area. After reviewing the plotted data, the data were combined for calculation of the summary statistics. For the unfiltered samples, there were 103 aquifer tube samples and 229 drive point samples. The unfiltered samples were collected between $9 / 24 / 2004$ and $2 / 24 / 2003$. For the filtered samples, there were 205 aquifer tube samples and 190 drive point samples. The filtered samples were collected between 4/12/2004 and 9/15/2005. The values are plotted in Figure A.5, and the data are presented in Table A.5.

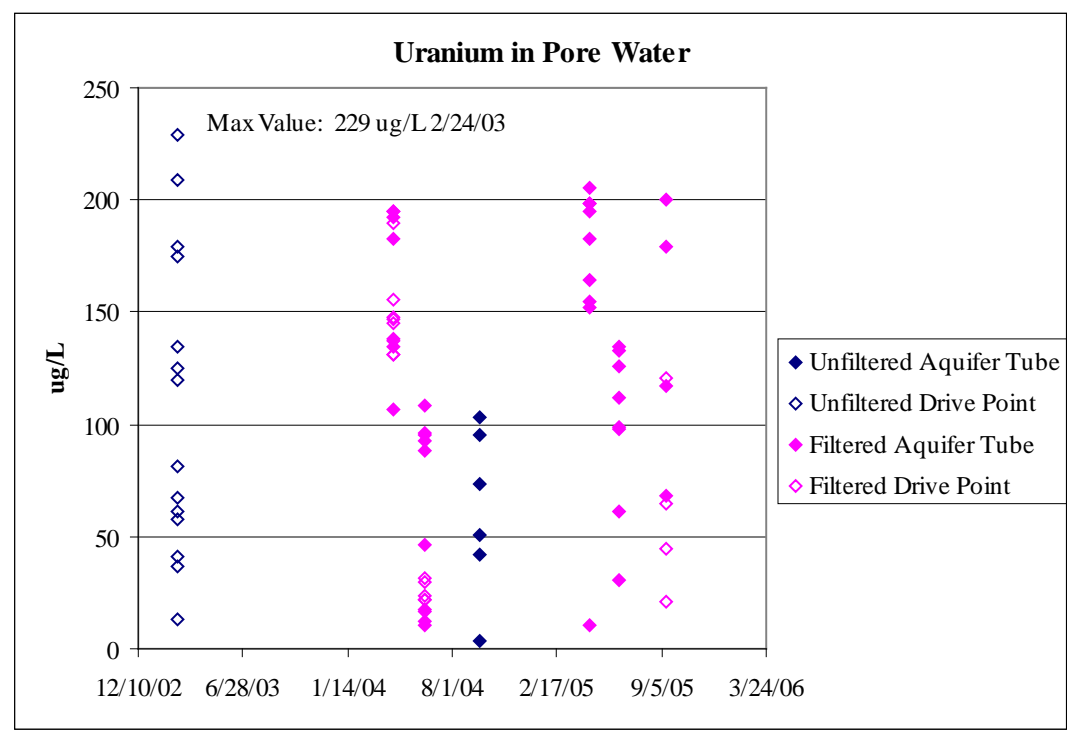

Figure A.5. Uranium in Pore Water Associated with the 300 Area 
Table A.5. Uranium Data in Aquifer Tubes and Drive Points in the 300 Area

\begin{tabular}{|c|c|c|c|c|c|c|}
\hline Analyte & Sampled From & Sample Number & Filtered Flag & Sample Date & $\begin{array}{l}\text { Value } \\
(\mu \mathrm{g} / \mathrm{L})\end{array}$ & Qualifier \\
\hline Uranium & Aquifer Tube & & $\mathrm{N}$ & $9 / 24 / 04$ & 3.53 & $\mathrm{X}$ \\
\hline Uranium & Aquifer Tube & & $\mathrm{N}$ & $9 / 24 / 04$ & 42 & $\mathrm{X}$ \\
\hline Uranium & Aquifer Tube & & $\mathrm{N}$ & $9 / 24 / 04$ & 50.5 & $\mathrm{X}$ \\
\hline Uranium & Aquifer Tube & & $\mathrm{N}$ & $9 / 24 / 04$ & 73.7 & $\mathrm{X}$ \\
\hline Uranium & Aquifer Tube & & $\mathrm{N}$ & $9 / 24 / 04$ & 94.9 & $\mathrm{X}$ \\
\hline Uranium & Aquifer Tube & & $\mathrm{N}$ & $9 / 24 / 04$ & 103 & $\mathrm{X}$ \\
\hline Uranium & Drive Point & & $\mathrm{N}$ & $2 / 24 / 03$ & 13 & $\mathrm{X}$ \\
\hline Uranium & Drive Point & & $\mathrm{N}$ & $2 / 24 / 03$ & 36.6 & $\mathrm{X}$ \\
\hline Uranium & Drive Point & & $\mathrm{N}$ & $2 / 24 / 03$ & 41.4 & $\mathrm{X}$ \\
\hline Uranium & Drive Point & & $\mathrm{N}$ & $2 / 24 / 03$ & 58.1 & $\mathrm{X}$ \\
\hline Uranium & Drive Point & & $\mathrm{N}$ & $2 / 24 / 03$ & 60.8 & $\mathrm{X}$ \\
\hline Uranium & Drive Point & & $\mathrm{N}$ & $2 / 24 / 03$ & 66.9 & $\mathrm{X}$ \\
\hline Uranium & Drive Point & & $\mathrm{N}$ & $2 / 24 / 03$ & 81.4 & $\mathrm{X}$ \\
\hline Uranium & Drive Point & & $\mathrm{N}$ & $2 / 24 / 03$ & 120 & $\mathrm{X}$ \\
\hline Uranium & Drive Point & & $\mathrm{N}$ & $2 / 24 / 03$ & 125 & $\mathrm{X}$ \\
\hline Uranium & Drive Point & & $\mathrm{N}$ & $2 / 24 / 03$ & 135 & $\mathrm{X}$ \\
\hline Uranium & Drive Point & & $\mathrm{N}$ & $2 / 24 / 03$ & 175 & $\mathrm{X}$ \\
\hline Uranium & Drive Point & & $\mathrm{N}$ & $2 / 24 / 03$ & 179 & $\mathrm{X}$ \\
\hline Uranium & Drive Point & & $\mathrm{N}$ & $2 / 24 / 03$ & 209 & $\mathrm{X}$ \\
\hline Uranium & Drive Point & & $\mathbf{N}$ & $2 / 24 / 03$ & 229 & $\mathrm{X}$ \\
\hline Uranium & Aquifer Tube & & $\mathrm{Y}$ & $4 / 19 / 05$ & 10.1 & $\mathrm{X}$ \\
\hline Uranium & Aquifer Tube & & $\mathrm{Y}$ & $6 / 10 / 04$ & 10.9 & $\mathrm{X}$ \\
\hline Uranium & Aquifer Tube & & $\mathrm{Y}$ & $6 / 10 / 04$ & 12 & $\mathrm{X}$ \\
\hline Uranium & Aquifer Tube & & $\mathrm{Y}$ & $6 / 10 / 04$ & 17.4 & $\mathrm{X}$ \\
\hline Uranium & Aquifer Tube & & $\mathrm{Y}$ & $6 / 15 / 05$ & 30.5 & $\mathrm{X}$ \\
\hline Uranium & Aquifer Tube & & $\mathrm{Y}$ & $6 / 10 / 04$ & 46.5 & $\mathrm{X}$ \\
\hline Uranium & Aquifer Tube & & $\mathrm{Y}$ & $6 / 15 / 05$ & 61.4 & $\mathrm{X}$ \\
\hline Uranium & Aquifer Tube & & $\mathrm{Y}$ & 9/15/05 & 68.6 & $\mathrm{X}$ \\
\hline Uranium & Aquifer Tube & & $\mathrm{Y}$ & $6 / 10 / 04$ & 88.2 & $\mathrm{X}$ \\
\hline Uranium & Aquifer Tube & & $\mathrm{Y}$ & $6 / 10 / 04$ & 92.7 & $\mathrm{X}$ \\
\hline Uranium & Aquifer Tube & & $\mathrm{Y}$ & $6 / 10 / 04$ & 95 & $\mathrm{X}$ \\
\hline Uranium & Aquifer Tube & & $\mathrm{Y}$ & $6 / 10 / 04$ & 96.3 & $\mathrm{X}$ \\
\hline Uranium & Aquifer Tube & & $\mathrm{Y}$ & $6 / 15 / 05$ & 97.5 & $\mathrm{X}$ \\
\hline Uranium & Aquifer Tube & & $\mathrm{Y}$ & $6 / 15 / 05$ & 99.2 & $\mathrm{X}$ \\
\hline Uranium & Aquifer Tube & & $\mathrm{Y}$ & $4 / 12 / 04$ & 107 & $\mathrm{X}$ \\
\hline Uranium & Aquifer Tube & & $\mathrm{Y}$ & $6 / 10 / 04$ & 108 & $\mathrm{X}$ \\
\hline Uranium & Aquifer Tube & & $\mathrm{Y}$ & $6 / 15 / 05$ & 112 & $\mathrm{X}$ \\
\hline Uranium & Aquifer Tube & & $\mathrm{Y}$ & $9 / 15 / 05$ & 117 & $\mathrm{X}$ \\
\hline Uranium & Aquifer Tube & & $\mathrm{Y}$ & $6 / 15 / 05$ & 126 & $\mathrm{X}$ \\
\hline Uranium & Aquifer Tube & & $\mathrm{Y}$ & $6 / 15 / 05$ & 133 & $\mathrm{X}$ \\
\hline Uranium & Aquifer Tube & & $\mathrm{Y}$ & $4 / 12 / 04$ & 135 & $\mathrm{X}$ \\
\hline Uranium & Aquifer Tube & & $\mathrm{Y}$ & $6 / 15 / 05$ & 135 & $\mathrm{X}$ \\
\hline Uranium & Aquifer Tube & & $\mathrm{Y}$ & $4 / 12 / 04$ & 138 & $\mathrm{X}$ \\
\hline
\end{tabular}


Table A.5. (contd)

\begin{tabular}{|c|c|c|c|c|c|c|}
\hline Analyte & Sampled From & Sample Number & Filtered Flag & Sample Date & $\begin{array}{l}\text { Value } \\
(\mu \mathrm{g} / \mathrm{L})\end{array}$ & Qualifier \\
\hline Uranium & Aquifer Tube & & $\overline{\mathrm{Y}}$ & $4 / 19 / 05$ & 152 & $\mathrm{X}$ \\
\hline Uranium & Aquifer Tube & & $\mathrm{Y}$ & $4 / 19 / 05$ & 155 & $\mathrm{X}$ \\
\hline Uranium & Aquifer Tube & & $\mathrm{Y}$ & $4 / 19 / 05$ & 164 & $\mathrm{X}$ \\
\hline Uranium & Aquifer Tube & & $\mathrm{Y}$ & 9/15/05 & 179 & $\mathrm{X}$ \\
\hline Uranium & Aquifer Tube & & $\mathrm{Y}$ & $4 / 12 / 04$ & 183 & $\mathrm{X}$ \\
\hline Uranium & Aquifer Tube & & $\mathrm{Y}$ & $4 / 19 / 05$ & 183 & $\mathrm{X}$ \\
\hline Uranium & Aquifer Tube & & $\mathrm{Y}$ & $4 / 12 / 04$ & 192 & $\mathrm{X}$ \\
\hline Uranium & Aquifer Tube & & $\mathrm{Y}$ & $4 / 12 / 04$ & 195 & $\mathrm{X}$ \\
\hline Uranium & Aquifer Tube & & $\mathrm{Y}$ & $4 / 12 / 04$ & 195 & $\mathrm{X}$ \\
\hline Uranium & Aquifer Tube & & $\mathrm{Y}$ & $4 / 19 / 05$ & 195 & $\mathrm{X}$ \\
\hline Uranium & Aquifer Tube & & $\mathrm{Y}$ & $4 / 19 / 05$ & 198 & $\mathrm{X}$ \\
\hline Uranium & Aquifer Tube & & $\mathrm{Y}$ & $4 / 19 / 05$ & 198 & $\mathrm{X}$ \\
\hline Uranium & Aquifer Tube & & $\mathrm{Y}$ & $9 / 15 / 05$ & 200 & $\mathrm{X}$ \\
\hline Uranium & Aquifer Tube & & $\mathrm{Y}$ & $4 / 19 / 05$ & 205 & $\mathrm{X}$ \\
\hline Uranium & Drive Point & & $\mathrm{Y}$ & $6 / 10 / 04$ & 16.6 & $\mathrm{X}$ \\
\hline Uranium & Drive Point & & $\mathrm{Y}$ & $9 / 15 / 05$ & 20.8 & $\mathrm{X}$ \\
\hline Uranium & Drive Point & & $\mathrm{Y}$ & $6 / 10 / 04$ & 21.7 & $\mathrm{X}$ \\
\hline Uranium & Drive Point & & $\mathrm{Y}$ & $6 / 10 / 04$ & 21.8 & $\mathrm{X}$ \\
\hline Uranium & Drive Point & & $\mathrm{Y}$ & $6 / 10 / 04$ & 23.9 & $\mathrm{X}$ \\
\hline Uranium & Drive Point & & $\mathrm{Y}$ & $6 / 10 / 04$ & 29.9 & $\mathrm{X}$ \\
\hline Uranium & Drive Point & & $\mathrm{Y}$ & $6 / 10 / 04$ & 31.9 & $\mathrm{X}$ \\
\hline Uranium & Drive Point & & $\mathrm{Y}$ & 9/15/05 & 44.3 & $\mathrm{X}$ \\
\hline Uranium & Drive Point & & $\mathrm{Y}$ & 9/15/05 & 64.8 & $\mathrm{X}$ \\
\hline Uranium & Drive Point & & $\mathrm{Y}$ & $9 / 15 / 05$ & 121 & $\mathrm{X}$ \\
\hline Uranium & Drive Point & & $\mathrm{Y}$ & $4 / 12 / 04$ & 131 & $\mathrm{X}$ \\
\hline Uranium & Drive Point & & $\mathrm{Y}$ & $4 / 12 / 04$ & 131 & $\mathrm{X}$ \\
\hline Uranium & Drive Point & & $\mathrm{Y}$ & $4 / 12 / 04$ & 137 & $\mathrm{X}$ \\
\hline Uranium & Drive Point & & $\mathrm{Y}$ & $4 / 12 / 04$ & 145 & $\mathrm{X}$ \\
\hline Uranium & Drive Point & & $\mathrm{Y}$ & $4 / 12 / 04$ & 147 & $\mathrm{X}$ \\
\hline Uranium & Drive Point & & $\mathrm{Y}$ & $4 / 12 / 04$ & 148 & $\mathrm{X}$ \\
\hline Uranium & Drive Point & & $\mathrm{Y}$ & $4 / 12 / 04$ & 156 & $\mathrm{X}$ \\
\hline Uranium & Drive Point & & $\mathrm{Y}$ & $4 / 12 / 04$ & 190 & $\mathrm{X}$ \\
\hline
\end{tabular}

\section{A.2.2 Uranium-234 Pore Water Data}

There were 22 aquifer tube samples of uranium-234 at the 300 Area location and 25 drive point samples. The aquifer tube samples were collected between 4/12/2004 and 9/24/2004. The drive point samples were collected between 9/17/2001 and 6/10/2004. The values are plotted in Figure A.6, and the data are presented in Table A.6. 


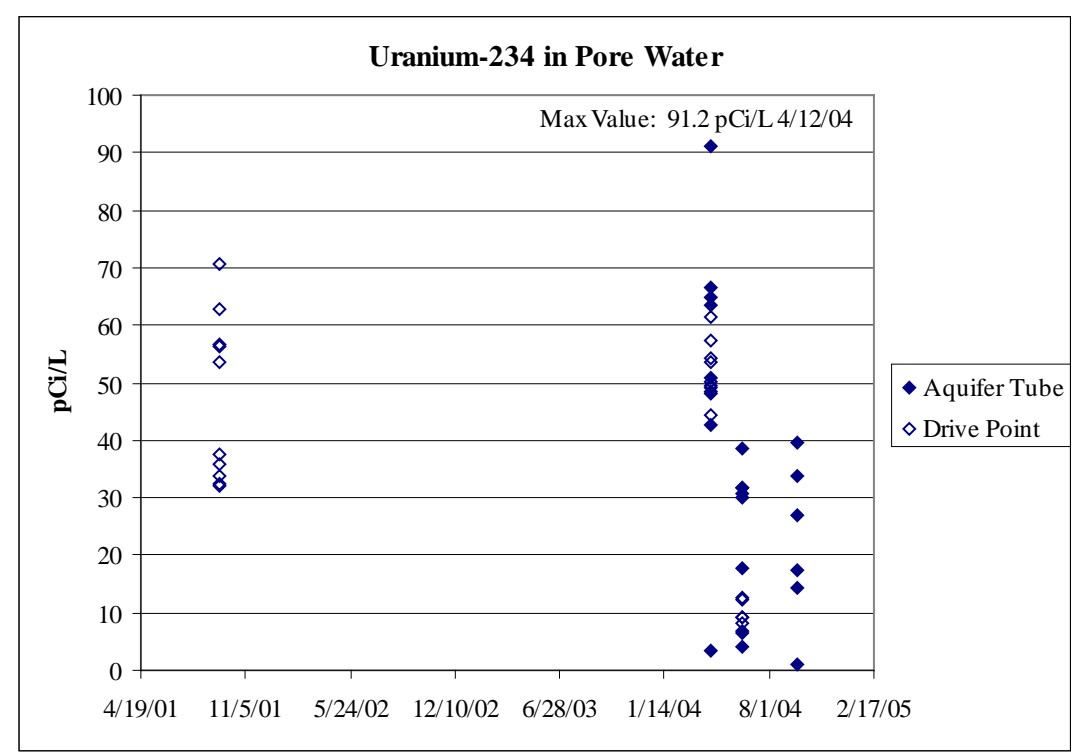

Figure A.6. Uranium-234 in Pore Water Associated with the 300 Area

Table A.6. Uranium-234 Data in Aquifer Tubes and Drive Points in the 300 Area

\begin{tabular}{|c|c|c|c|c|c|c|c|c|}
\hline Analyte & Sampled From & $\begin{array}{c}\text { Sample } \\
\text { Number }\end{array}$ & $\begin{array}{c}\text { Filtered } \\
\text { Flag }\end{array}$ & $\begin{array}{c}\text { Sample } \\
\text { Date } \\
\end{array}$ & $\begin{array}{c}\text { Value } \\
\text { (pCi/L) }\end{array}$ & $\begin{array}{c}\text { Counting } \\
\text { Error } \\
\end{array}$ & MDA & Qualifier \\
\hline Uranium-234 & Aquifer Tube & B190Y9 & $\mathrm{N}$ & $4 / 12 / 04$ & 64.8 & 0.57 & 0.00339 & \\
\hline Uranium-234 & Aquifer Tube & B190Y7 & $\mathbf{N}$ & $4 / 12 / 04$ & 91.2 & 0.94 & 0.0636 & \\
\hline Uranium-234 & Aquifer Tube & B19105 & $\mathrm{N}$ & $4 / 12 / 04$ & 48.2 & 0.52 & 0.0325 & \\
\hline Uranium-234 & Aquifer Tube & B19101 & $\mathrm{N}$ & $4 / 12 / 04$ & 42.6 & 0.52 & 0.0118 & \\
\hline Uranium-234 & Aquifer Tube & B19103 & $\mathrm{N}$ & $4 / 12 / 04$ & 50.7 & 0.58 & 0.012 & \\
\hline Uranium-234 & Aquifer Tube & B190Y3 & $\mathrm{N}$ & $4 / 12 / 04$ & 63.6 & 0.62 & 0.0228 & \\
\hline Uranium-234 & Aquifer Tube & B190Y1 & $\mathrm{N}$ & $4 / 12 / 04$ & 3.37 & 0.16 & 0.032 & \\
\hline Uranium-234 & Aquifer Tube & B190Y5 & $\mathrm{N}$ & $4 / 12 / 04$ & 66.6 & 0.61 & 0.04 & \\
\hline Uranium-234 & Aquifer Tube & B19HD8 & $\mathrm{N}$ & $6 / 10 / 04$ & 30.7 & 0.51 & 0.0166 & \\
\hline Uranium-234 & Aquifer Tube & B19HB8 & $\mathrm{N}$ & $6 / 10 / 04$ & 31.8 & 0.7 & 0.033 & \\
\hline Uranium-234 & Aquifer Tube & B19HB4 & $\mathrm{N}$ & $6 / 10 / 04$ & 38.6 & 0.51 & 0.0174 & \\
\hline Uranium-234 & Aquifer Tube & B19HD0 & $\mathrm{N}$ & $6 / 10 / 04$ & 17.6 & 0.35 & 0.0291 & \\
\hline Uranium-234 & Aquifer Tube & B19HC2 & $\mathrm{N}$ & $6 / 10 / 04$ & 4.11 & 0.19 & 0.0159 & \\
\hline Uranium-234 & Aquifer Tube & B19HC6 & $\mathrm{N}$ & $6 / 10 / 04$ & 6.54 & 0.23 & 0.00565 & \\
\hline Uranium-234 & Aquifer Tube & В19H96 & $\mathrm{N}$ & $6 / 10 / 04$ & 31.7 & 0.49 & 0.00523 & \\
\hline Uranium-234 & Aquifer Tube & B19HB0 & $\mathrm{N}$ & $6 / 10 / 04$ & 30 & 0.44 & 0.0116 & \\
\hline Uranium-234 & Aquifer Tube & B1BCB4 & $\mathrm{N}$ & $9 / 24 / 04$ & 17.3 & 0.39 & 0.0304 & \\
\hline Uranium-234 & Aquifer Tube & B1BC96 & $\mathrm{N}$ & $9 / 24 / 04$ & 33.8 & 0.44 & 0.0105 & \\
\hline Uranium-234 & Aquifer Tube & B1BC92 & $\mathrm{N}$ & $9 / 24 / 04$ & 39.6 & 0.59 & 0.0237 & \\
\hline Uranium-234 & Aquifer Tube & B1BC84 & $\mathrm{N}$ & $9 / 24 / 04$ & 27 & 0.4 & 0.0101 & \\
\hline Uranium-234 & Aquifer Tube & B1BC80 & $\mathrm{N}$ & $9 / 24 / 04$ & 1.09 & 0.087 & 0.00969 & \\
\hline Uranium-234 & Aquifer Tube & B1BC88 & $\mathrm{N}$ & $9 / 24 / 04$ & 14.4 & 0.34 & 0.0169 & \\
\hline Uranium-234 & Drive Point & B12XK8 & $\mathrm{N}$ & 9/17/01 & 35.7 & 0.52 & 0.0107 & \\
\hline Uranium-234 & Drive Point & B12XK9 & $\mathrm{N}$ & 9/17/01 & 53.7 & 0.6 & 0.013 & \\
\hline Uranium-234 & Drive Point & B12XL0 & $\mathrm{N}$ & 9/17/01 & 56.6 & 0.6 & 0.0137 & \\
\hline Uranium-234 & Drive Point & B12XL1 & $\mathrm{N}$ & 9/17/01 & 56.3 & 0.62 & 0.0116 & \\
\hline Uranium-234 & Drive Point & B12XL2 & $\mathrm{N}$ & 9/17/01 & 70.5 & 0.66 & 0.0131 & \\
\hline Uranium-234 & Drive Point & B12XK3 & $\mathrm{N}$ & 9/18/01 & 62.8 & 0.62 & 0.0121 & \\
\hline
\end{tabular}


Table A.5. (contd)

\begin{tabular}{||c|c|c|c|c|c|c|c|c||}
\hline \hline Analyte & Sampled From & $\begin{array}{c}\text { Sample } \\
\text { Number }\end{array}$ & $\begin{array}{c}\text { Filtered } \\
\text { Flag }\end{array}$ & $\begin{array}{c}\text { Sample } \\
\text { Date }\end{array}$ & $\begin{array}{c}\text { Value } \\
\text { (pCi/L) }\end{array}$ & $\begin{array}{c}\text { Counting } \\
\text { Error }\end{array}$ & MDA & Qualifier \\
\hline \hline Uranium-234 & Drive Point & B12XK4 & $\mathrm{N}$ & $9 / 18 / 01$ & 32.3 & 0.46 & 0.0125 & \\
\hline Uranium-234 & Drive Point & B12XK5 & $\mathrm{N}$ & $9 / 18 / 01$ & 33.7 & 0.57 & 0.0188 & \\
\hline Uranium-234 & Drive Point & B12XK6 & $\mathrm{N}$ & $9 / 18 / 01$ & 32.2 & 0.52 & 0.0196 & \\
\hline Uranium-234 & Drive Point & B12XK7 & $\mathrm{N}$ & $9 / 18 / 01$ & 37.4 & 0.5 & 0.0219 & \\
\hline Uranium-234 & Drive Point & B190W3 & $\mathrm{N}$ & $4 / 12 / 04$ & 48.5 & 0.49 & 0.0175 & \\
\hline Uranium-234 & Drive Point & B190W5 & $\mathrm{N}$ & $4 / 12 / 04$ & 53.6 & 0.67 & 0.0155 & \\
\hline Uranium-234 & Drive Point & B190W1 & $\mathrm{N}$ & $4 / 12 / 04$ & 49.6 & 0.52 & 0.00997 & \\
\hline Uranium-234 & Drive Point & B190W7 & $\mathrm{N}$ & $4 / 12 / 04$ & 50.1 & 0.57 & 0.0152 & \\
\hline Uranium-234 & Drive Point & B190X1 & $\mathrm{N}$ & $4 / 12 / 04$ & 54.3 & 0.55 & 0.0212 & \\
\hline Uranium-234 & Drive Point & B190W9 & $\mathrm{N}$ & $4 / 12 / 04$ & 44.5 & 0.48 & 0.0157 & \\
\hline Uranium-234 & Drive Point & B190X3 & $\mathrm{N}$ & $4 / 12 / 04$ & 49.2 & 0.51 & 0.0136 & \\
\hline Uranium-234 & Drive Point & B190X5 & $\mathrm{N}$ & $4 / 12 / 04$ & 61.5 & 0.79 & 0.0197 & \\
\hline Uranium-234 & Drive Point & B190X9 & $\mathrm{N}$ & $4 / 12 / 04$ & 57.4 & 0.61 & 0.0125 & \\
\hline Uranium-234 & Drive Point & B19H28 & $\mathrm{N}$ & $6 / 10 / 04$ & 9.19 & 0.29 & 0.0296 & \\
\hline Uranium-234 & Drive Point & B19H32 & $\mathrm{N}$ & $6 / 10 / 04$ & 8.1 & 0.25 & 0.0174 & \\
\hline Uranium-234 & Drive Point & B19H40 & $\mathrm{N}$ & $6 / 10 / 04$ & 12.3 & 0.28 & 0.0118 & \\
\hline Uranium-234 & Drive Point & B19H44 & $\mathrm{N}$ & $6 / 10 / 04$ & 12.7 & 0.29 & 0.0122 & \\
\hline Uranium-234 & Drive Point & B19H48 & $\mathrm{N}$ & $6 / 10 / 04$ & 9.15 & 0.23 & 0.0256 & \\
\hline Uranium-234 & Drive Point & B19H56 & $\mathrm{N}$ & $6 / 10 / 04$ & 6.83 & 0.2 & 0.0175 & \\
\hline
\end{tabular}

\section{A.2.3 Uranium-235 Pore Water Data}

There were 28 aquifer tube samples of uranium-235 at the 300 Area location and 35 drive point samples. The aquifer tube samples were collected between $4 / 12 / 2004$ and $9 / 29 / 2005$. The drive point samples were collected between 9/17/2001 and 9/29/2005. The values are plotted in Figure A.7, and the data are presented in Table A.7.

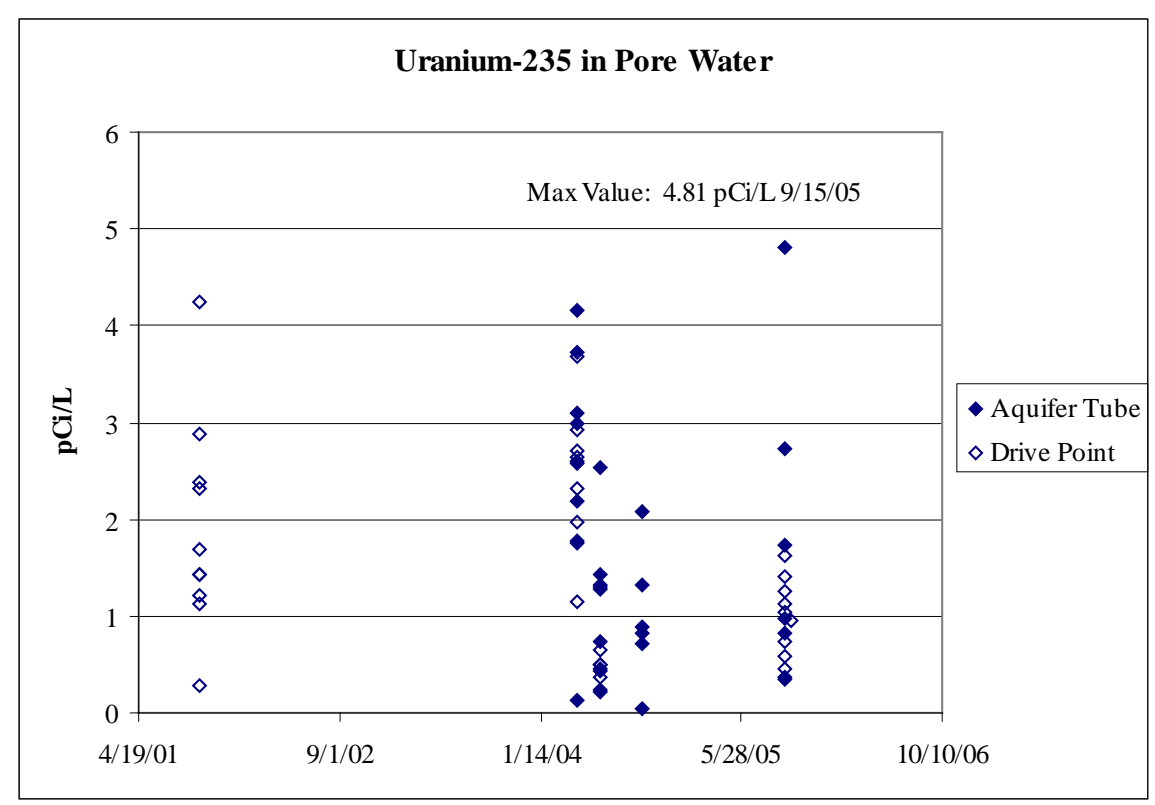

Figure A.7. Uranium-235 in Pore Water Associated with the 300 Area 
Table A.7. Uranium-235 Data in Aquifer Tubes and Drive Points in the 300 Area

\begin{tabular}{|c|c|c|c|c|c|c|c|c|}
\hline Analyte & Sampled From & $\begin{array}{l}\text { Sample } \\
\text { Number }\end{array}$ & $\begin{array}{c}\text { Filtered } \\
\text { Flag }\end{array}$ & $\begin{array}{c}\text { Sample } \\
\text { Date }\end{array}$ & $\begin{array}{c}\text { Value } \\
\text { (pCi/L) }\end{array}$ & $\begin{array}{c}\text { Counting } \\
\text { Error }\end{array}$ & MDA & Qualifier \\
\hline "Uranium-235 & Aquifer Tube & B1BC80 & $\mathrm{N}$ & 9/24/04 & 0.0451 & 0.018 & 0.0134 & \\
\hline Uranium-235 & Aquifer Tube & B190Y1 & $\mathrm{N}$ & $4 / 12 / 04$ & 0.124 & 0.031 & 0.019 & \\
\hline Uranium-235 & Aquifer Tube & B19HC2 & $\mathrm{N}$ & $6 / 10 / 04$ & 0.211 & 0.043 & 0.00586 & \\
\hline Uranium-235 & Aquifer Tube & & $\mathrm{N}$ & $9 / 15 / 05$ & 0.365 & 0.051 & 0.00991 & \\
\hline Uranium-235 & Aquifer Tube & B19HC6 & $\mathrm{N}$ & $6 / 10 / 04$ & 0.455 & 0.062 & 0.00565 & \\
\hline Uranium-235 & Aquifer Tube & B1BC88 & $\mathrm{N}$ & $9 / 24 / 04$ & 0.713 & 0.075 & 0.0154 & \\
\hline Uranium-235 & Aquifer Tube & B19HD0 & $\mathrm{N}$ & $6 / 10 / 04$ & 0.731 & 0.072 & 0.0162 & \\
\hline Uranium-235 & Aquifer Tube & & $\mathrm{N}$ & 9/15/05 & 0.822 & 0.072 & 0.0043 & \\
\hline Uranium-235 & Aquifer Tube & B1BCB4 & $\mathrm{N}$ & $9 / 24 / 04$ & 0.829 & 0.085 & 0.02 & \\
\hline Uranium-235 & Aquifer Tube & B1BC84 & $\mathrm{N}$ & $9 / 24 / 04$ & 0.882 & 0.072 & 0.00397 & \\
\hline Uranium-235 & Aquifer Tube & & $\mathrm{N}$ & 9/15/05 & 0.982 & 0.077 & 0.0117 & \\
\hline Uranium-235 & Aquifer Tube & B19HD8 & $\mathrm{N}$ & 6/10/04 & 1.28 & 0.1 & 0.00575 & \\
\hline Uranium-235 & Aquifer Tube & B19HB8 & $\mathrm{N}$ & $6 / 10 / 04$ & 1.31 & 0.14 & 0.0217 & \\
\hline Uranium-235 & Aquifer Tube & B19H96 & $\mathrm{N}$ & $6 / 10 / 04$ & 1.33 & 0.1 & 0.0142 & \\
\hline Uranium-235 & Aquifer Tube & B1BC96 & $\mathrm{N}$ & $9 / 24 / 04$ & 1.33 & 0.087 & 0.00388 & \\
\hline Uranium-235 & Aquifer Tube & B19HB0 & $\mathrm{N}$ & $6 / 10 / 04$ & 1.42 & 0.095 & 0.0116 & \\
\hline Uranium-235 & Aquifer Tube & & $\mathrm{N}$ & 9/15/05 & 1.74 & 0.095 & 0.0102 & \\
\hline Uranium-235 & Aquifer Tube & B19101 & $\mathrm{N}$ & $4 / 12 / 04$ & 1.78 & 0.11 & 0.0118 & \\
\hline Uranium-235 & Aquifer Tube & B1BC92 & $\mathrm{N}$ & $9 / 24 / 04$ & 2.08 & 0.14 & 0.00597 & \\
\hline Uranium-235 & Aquifer Tube & B190Y3 & $\mathrm{N}$ & $4 / 12 / 04$ & 2.18 & 0.12 & 0.0112 & \\
\hline Uranium-235 & Aquifer Tube & B19HB4 & $\mathrm{N}$ & $6 / 10 / 04$ & 2.53 & 0.13 & 0.0154 & \\
\hline Uranium-235 & Aquifer Tube & B190Y5 & $\mathrm{N}$ & $4 / 12 / 04$ & 2.57 & 0.12 & 0.021 & \\
\hline Uranium-235 & Aquifer Tube & & $\mathrm{N}$ & 9/15/05 & 2.73 & 0.14 & 0.00466 & \\
\hline Uranium-235 & Aquifer Tube & B19105 & $\mathrm{N}$ & $4 / 12 / 04$ & 2.98 & 0.13 & 0.0166 & \\
\hline Uranium-235 & Aquifer Tube & B19103 & $\mathrm{N}$ & $4 / 12 / 04$ & 3.1 & 0.14 & 0.00443 & \\
\hline Uranium-235 & Aquifer Tube & B190Y7 & $\mathrm{N}$ & $4 / 12 / 04$ & 3.73 & 0.19 & 0.0436 & \\
\hline Uranium-235 & Aquifer Tube & B190Y9 & $\mathrm{N}$ & $4 / 12 / 04$ & 4.15 & 0.14 & 0.00339 & \\
\hline Uranium-235 & Aquifer Tube & & $\mathbf{N}$ & 9/15/05 & 4.81 & 0.2 & 0.0147 & \\
\hline Uranium-235 & Drive Point & B19H56 & $\mathrm{N}$ & 6/10/04 & 0.228 & 0.037 & 0.0107 & \\
\hline Uranium-235 & Drive Point & B12XK7 & $\mathrm{N}$ & 9/18/01 & 0.292 & 0.045 & 0.00461 & \\
\hline Uranium-235 & Drive Point & & $\mathrm{N}$ & $9 / 15 / 05$ & 0.351 & 0.045 & 0.00822 & \\
\hline Uranium-235 & Drive Point & B19H28 & $\mathrm{N}$ & $6 / 10 / 04$ & 0.374 & 0.059 & 0.0166 & \\
\hline Uranium-235 & Drive Point & B19H48 & $\mathrm{N}$ & $6 / 10 / 04$ & 0.425 & 0.051 & 0.0158 & \\
\hline Uranium-235 & Drive Point & & $\mathrm{N}$ & $9 / 15 / 05$ & 0.463 & 0.049 & 0.0101 & \\
\hline Uranium-235 & Drive Point & B19H32 & $\mathrm{N}$ & $6 / 10 / 04$ & 0.496 & 0.061 & 0.00508 & \\
\hline Uranium-235 & Drive Point & B19H40 & $\mathrm{N}$ & $6 / 10 / 04$ & 0.499 & 0.057 & 0.00435 & \\
\hline Uranium-235 & Drive Point & & $\mathrm{N}$ & 9/15/05 & 0.577 & 0.056 & 0.00363 & \\
\hline Uranium-235 & Drive Point & B19H44 & $\mathrm{N}$ & $6 / 10 / 04$ & 0.656 & 0.066 & 0.0122 & \\
\hline Uranium-235 & Drive Point & & $\mathrm{N}$ & 9/15/05 & 0.741 & 0.064 & 0.0107 & \\
\hline Uranium-235 & Drive Point & & $\mathrm{N}$ & 9/29/05 & 0.959 & 0.085 & 0.00515 & \\
\hline Uranium-235 & Drive Point & & $\mathrm{N}$ & 9/15/05 & 1.03 & 0.075 & 0.0101 & \\
\hline Uranium-235 & Drive Point & & $\mathrm{N}$ & 9/15/05 & 1.12 & 0.076 & 0.00885 & \\
\hline Uranium-235 & Drive Point & B12XK9 & $\mathrm{N}$ & $9 / 17 / 01$ & 1.13 & 0.087 & 0.0045 & \\
\hline Uranium-235 & Drive Point & B190X3 & $\mathrm{N}$ & $4 / 12 / 04$ & 1.15 & 0.077 & 0.00351 & \\
\hline Uranium-235 & Drive Point & B12XK4 & $\mathrm{N}$ & 9/18/01 & 1.21 & 0.088 & 0.00435 & \\
\hline Uranium-235 & Drive Point & & $\mathrm{N}$ & 9/15/05 & 1.26 & 0.12 & 0.0207 & \\
\hline Uranium-235 & Drive Point & & $\mathrm{N}$ & 9/15/05 & 1.41 & 0.096 & 0.0119 & \\
\hline Uranium-235 & Drive Point & B12XK6 & $\mathrm{N}$ & 9/18/01 & 1.43 & 0.11 & 0.00573 & \\
\hline Uranium-235 & Drive Point & B12XK5 & $\mathrm{N}$ & 9/18/01 & 1.43 & 0.12 & 0.00653 & \\
\hline Uranium-235 & Drive Point & & $\mathrm{N}$ & 9/15/05 & 1.63 & 0.1 & 0.0118 & \\
\hline
\end{tabular}


Table A.7. (contd)

\begin{tabular}{|c|c|c|c|c|c|c|c|c|}
\hline Analyte & Sampled From & $\begin{array}{l}\text { Sample } \\
\text { Number }\end{array}$ & $\begin{array}{c}\text { Filtered } \\
\text { Flag }\end{array}$ & $\begin{array}{c}\text { Sample } \\
\text { Date }\end{array}$ & $\begin{array}{l}\text { Value } \\
(\mathrm{pCi} / \mathrm{L})\end{array}$ & $\begin{array}{c}\text { Counting } \\
\text { Error }\end{array}$ & MDA & Qualifier \\
\hline Uranium-235 & Drive Point & B12XK8 & $\mathrm{N}$ & 9/17/01 & 1.7 & 0.11 & 0.00515 & \\
\hline Uranium-235 & Drive Point & B190W5 & $\mathrm{N}$ & $4 / 12 / 04$ & 1.75 & 0.12 & 0.0155 & \\
\hline Uranium-235 & Drive Point & B190W9 & $\mathrm{N}$ & $4 / 12 / 04$ & 1.98 & 0.1 & 0.0169 & \\
\hline Uranium-235 & Drive Point & B190W1 & $\mathrm{N}$ & $4 / 12 / 04$ & 2.31 & 0.11 & 0.00367 & \\
\hline Uranium-235 & Drive Point & B12XL1 & $\mathrm{N}$ & 9/17/01 & 2.32 & 0.13 & 0.0116 & \\
\hline Uranium-235 & Drive Point & B12XL0 & $\mathrm{N}$ & $9 / 17 / 01$ & 2.38 & 0.12 & 0.00432 & \\
\hline Uranium-235 & Drive Point & B190W3 & $\mathrm{N}$ & $4 / 12 / 04$ & 2.6 & 0.11 & 0.00915 & \\
\hline Uranium-235 & Drive Point & B190X5 & $\mathrm{N}$ & $4 / 12 / 04$ & 2.65 & 0.16 & 0.0143 & \\
\hline Uranium-235 & Drive Point & B190X1 & $\mathrm{N}$ & $4 / 12 / 04$ & 2.7 & 0.12 & 0.00939 & \\
\hline Uranium-235 & Drive Point & B12XK3 & $\mathrm{N}$ & 9/18/01 & 2.88 & 0.13 & 0.00878 & \\
\hline Uranium-235 & Drive Point & B190X9 & $\mathrm{N}$ & $4 / 12 / 04$ & 2.92 & 0.14 & 0.00434 & \\
\hline Uranium-235 & Drive Point & B190W7 & $\mathrm{N}$ & $4 / 12 / 04$ & 3.69 & 0.16 & 0.012 & \\
\hline Uranium-235 & Drive Point & B12XL2 & $\mathrm{N}$ & $9 / 17 / 01$ & 4.25 & 0.16 & 0.00414 & \\
\hline
\end{tabular}

\section{A.2.4 Uranium-238 Pore Water Data}

There were 28 aquifer tube samples of uranium-238 at the 300 Area location and 35 drive point samples. The aquifer tube samples were collected between 4/12/2004 and 9/15/2005. The drive point samples were collected between 9/17/2001 and 9/29/2005. The values are plotted in Figure A.8, and the data are presented in Table A.8.

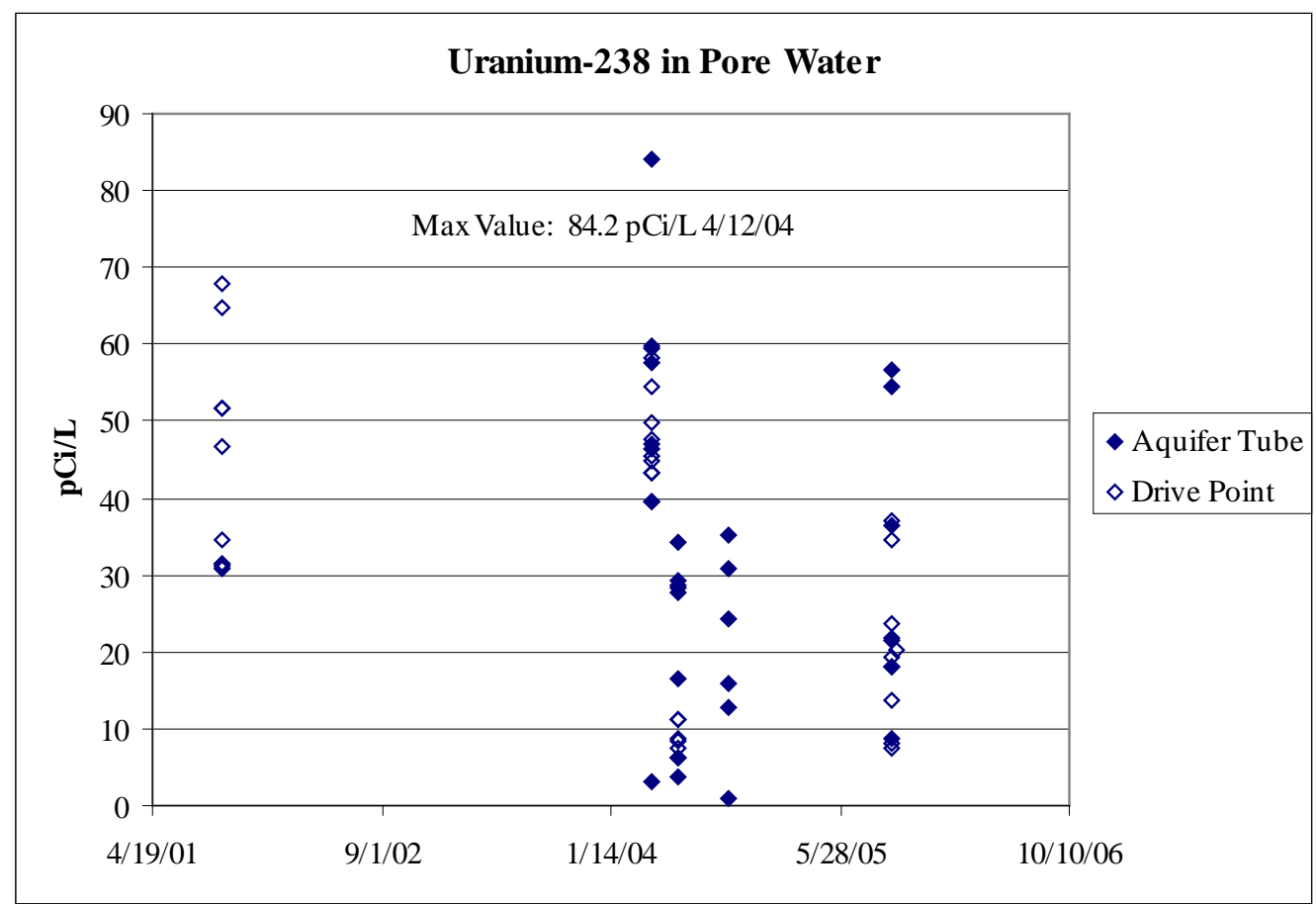

Figure A.8. Uranium-238 in Pore Water Associated with the 300 Area 
Table A.8. Uranium-238 Data in Aquifer Tubes and Drive Points in the 300 Area

\begin{tabular}{|c|c|c|c|c|c|c|c|c|}
\hline Analyte & Sampled From & $\begin{array}{l}\text { Sample } \\
\text { Number }\end{array}$ & $\begin{array}{c}\text { Filtered } \\
\text { Flag }\end{array}$ & $\begin{array}{c}\text { Sample } \\
\text { Date }\end{array}$ & $\begin{array}{c}\text { Value } \\
\text { (pCi/L) }\end{array}$ & $\begin{array}{c}\text { Counting } \\
\text { Error }\end{array}$ & MDA & Qualifier \\
\hline Uranium-238 & Aquifer Tube & B1BC80 & $\mathrm{N}$ & 9/24/04 & 1.06 & 0.086 & 0.0118 & \\
\hline Uranium-238 & Aquifer Tube & B190Y1 & $\mathrm{N}$ & $4 / 12 / 04$ & 3.24 & 0.15 & 0.028 & \\
\hline Uranium-238 & Aquifer Tube & B19HC2 & $\mathrm{N}$ & $6 / 10 / 04$ & 3.75 & 0.18 & 0.00586 & \\
\hline Uranium-238 & Aquifer Tube & B19HC6 & $\mathrm{N}$ & $6 / 10 / 04$ & 6.1 & 0.23 & 0.0153 & \\
\hline Uranium-238 & Aquifer Tube & & $\mathrm{N}$ & $9 / 15 / 05$ & 8.75 & 0.25 & 0.0163 & \\
\hline Uranium-238 & Aquifer Tube & B1BC88 & $\mathrm{N}$ & $9 / 24 / 04$ & 12.8 & 0.32 & 0.00533 & \\
\hline Uranium-238 & Aquifer Tube & B1BCB4 & $\mathrm{N}$ & $9 / 24 / 04$ & 15.9 & 0.37 & 0.02 & \\
\hline Uranium-238 & Aquifer Tube & B19HD0 & $\mathrm{N}$ & $6 / 10 / 04$ & 16.5 & 0.34 & 0.0229 & \\
\hline Uranium-238 & Aquifer Tube & & $\mathrm{N}$ & 9/15/05 & 18.2 & 0.34 & 0.0043 & \\
\hline Uranium-238 & Aquifer Tube & & $\mathrm{N}$ & 9/15/05 & 21.6 & 0.36 & 0.00848 & \\
\hline Uranium-238 & Aquifer Tube & B1BC84 & $\mathrm{N}$ & $9 / 24 / 04$ & 24.3 & 0.38 & 0.00827 & \\
\hline Uranium-238 & Aquifer Tube & B19HB0 & $\mathrm{N}$ & $6 / 10 / 04$ & 27.7 & 0.42 & 0.0146 & \\
\hline Uranium-238 & Aquifer Tube & B19HD8 & $\mathrm{N}$ & $6 / 10 / 04$ & 28.3 & 0.49 & 0.012 & \\
\hline Uranium-238 & Aquifer Tube & B19HB8 & $\mathrm{N}$ & $6 / 10 / 04$ & 28.8 & 0.67 & 0.0104 & \\
\hline Uranium-238 & Aquifer Tube & В19H96 & $\mathrm{N}$ & $6 / 10 / 04$ & 29.3 & 0.48 & 0.00523 & \\
\hline Uranium-238 & Aquifer Tube & B1BC96 & $\mathrm{N}$ & $9 / 24 / 04$ & 30.8 & 0.42 & 0.00388 & \\
\hline Uranium-238 & Aquifer Tube & B19HB4 & $\mathrm{N}$ & $6 / 10 / 04$ & 34.4 & 0.48 & 0.0164 & \\
\hline Uranium-238 & Aquifer Tube & B1BC92 & $\mathrm{N}$ & $9 / 24 / 04$ & 35.1 & 0.56 & 0.00597 & \\
\hline Uranium-238 & Aquifer Tube & & $\mathrm{N}$ & 9/15/05 & 36.5 & 0.44 & 0.0121 & \\
\hline Uranium-238 & Aquifer Tube & B19101 & $\mathrm{N}$ & $4 / 12 / 04$ & 39.5 & 0.5 & 0.0149 & \\
\hline Uranium-238 & Aquifer Tube & B19103 & $\mathrm{N}$ & $4 / 12 / 04$ & 46.4 & 0.55 & 0.00443 & \\
\hline Uranium-238 & Aquifer Tube & B19105 & $\mathrm{N}$ & $4 / 12 / 04$ & 46.9 & 0.51 & 0.026 & \\
\hline Uranium-238 & Aquifer Tube & & $\mathrm{N}$ & 9/15/05 & 54.4 & 0.61 & 0.0134 & \\
\hline Uranium-238 & Aquifer Tube & & $\mathrm{N}$ & 9/15/05 & 56.8 & 0.7 & 0.0121 & \\
\hline Uranium-238 & Aquifer Tube & B190Y3 & $\mathrm{N}$ & $4 / 12 / 04$ & 57.5 & 0.59 & 0.024 & \\
\hline Uranium-238 & Aquifer Tube & B190Y5 & $\mathrm{N}$ & $4 / 12 / 04$ & 59.5 & 0.58 & 0.0336 & \\
\hline Uranium-238 & Aquifer Tube & B190Y9 & $\mathrm{N}$ & $4 / 12 / 04$ & 59.9 & 0.55 & 0.00339 & \\
\hline Uranium-238 & Aquifer Tube & B190Y7 & $\mathbf{N}$ & $4 / 12 / 04$ & 84.2 & 0.9 & 0.0436 & \\
\hline Uranium-238 & Drive Point & B19H56 & $\mathrm{N}$ & $6 / 10 / 04$ & 6.11 & 0.19 & 0.0135 & \\
\hline Uranium-238 & Drive Point & В19H32 & $\mathrm{N}$ & $6 / 10 / 04$ & 7.41 & 0.24 & 0.0225 & \\
\hline Uranium-238 & Drive Point & & $\mathrm{N}$ & 9/15/05 & 7.57 & 0.21 & 0.0153 & \\
\hline Uranium-238 & Drive Point & & $\mathrm{N}$ & $9 / 15 / 05$ & 8.15 & 0.21 & 0.0112 & \\
\hline Uranium-238 & Drive Point & B19H28 & $\mathrm{N}$ & $6 / 10 / 04$ & 8.36 & 0.28 & 0.0394 & \\
\hline Uranium-238 & Drive Point & B19H48 & $\mathrm{N}$ & $6 / 10 / 04$ & 8.78 & 0.23 & 0.0256 & \\
\hline Uranium-238 & Drive Point & B19H40 & $\mathrm{N}$ & $6 / 10 / 04$ & 11.1 & 0.27 & 0.0173 & \\
\hline Uranium-238 & Drive Point & B19H44 & $\mathrm{N}$ & $6 / 10 / 04$ & 11.3 & 0.27 & 0.0199 & \\
\hline Uranium-238 & Drive Point & & $\mathrm{N}$ & 9/15/05 & 13.8 & 0.27 & 0.00363 & \\
\hline Uranium-238 & Drive Point & & $\mathrm{N}$ & 9/15/05 & 18.1 & 0.31 & 0.0094 & \\
\hline Uranium-238 & Drive Point & & $\mathrm{N}$ & 9/15/05 & 19.3 & 0.48 & 0.00816 & \\
\hline Uranium-238 & Drive Point & & $\mathrm{N}$ & 9/29/05 & 20.2 & 0.39 & 0.00515 & \\
\hline Uranium-238 & Drive Point & & $\mathrm{N}$ & 9/15/05 & 21.8 & 0.35 & 0.00372 & \\
\hline Uranium-238 & Drive Point & & $\mathrm{N}$ & 9/15/05 & 23.8 & 0.35 & 0.0172 & \\
\hline Uranium-238 & Drive Point & B12XK6 & $\mathrm{N}$ & 9/18/01 & 30.9 & 0.51 & 0.012 & \\
\hline Uranium-238 & Drive Point & B12XK4 & $\mathrm{N}$ & 9/18/01 & 31.2 & 0.45 & 0.00435 & \\
\hline Uranium-238 & Drive Point & B12XK5 & $\mathrm{N}$ & 9/18/01 & 31.5 & 0.55 & 0.0188 & \\
\hline Uranium-238 & Drive Point & B12XK8 & $\mathrm{N}$ & 9/17/01 & 31.6 & 0.49 & 0.0107 & \\
\hline Uranium-238 & Drive Point & B12XK7 & $\mathrm{N}$ & $9 / 18 / 01$ & 34.6 & 0.49 & 0.0188 & \\
\hline Uranium-238 & Drive Point & & $\mathrm{N}$ & 9/15/05 & 34.6 & 0.47 & 0.00439 & \\
\hline Uranium-238 & Drive Point & & $\mathrm{N}$ & 9/15/05 & 37 & 0.49 & 0.0149 & \\
\hline Uranium-238 & Drive Point & B190W9 & $\mathrm{N}$ & $4 / 12 / 04$ & 39.7 & 0.46 & 0.0169 & \\
\hline
\end{tabular}


Table A.8. (contd)

\begin{tabular}{|c|c|c|c|c|c|c|c|c|}
\hline Analyte & Sampled From & $\begin{array}{l}\text { Sample } \\
\text { Number }\end{array}$ & $\begin{array}{c}\text { Filtered } \\
\text { Flag }\end{array}$ & $\begin{array}{c}\text { Sample } \\
\text { Date }\end{array}$ & $\begin{array}{c}\text { Value } \\
\text { (pCi/L) }\end{array}$ & $\begin{array}{c}\text { Counting } \\
\text { Error }\end{array}$ & MDA & Qualifier \\
\hline Uranium-238 & Drive Point & B190W1 & $\mathrm{N}$ & $4 / 12 / 04$ & 43.2 & 0.48 & 0.0126 & \\
\hline Uranium-238 & Drive Point & B190W3 & $\mathrm{N}$ & $4 / 12 / 04$ & 43.3 & 0.46 & 0.0175 & \\
\hline Uranium-238 & Drive Point & B190X3 & $\mathrm{N}$ & $4 / 12 / 04$ & 44.9 & 0.48 & 0.0111 & \\
\hline Uranium-238 & Drive Point & B190W7 & $\mathrm{N}$ & $4 / 12 / 04$ & 45.6 & 0.55 & 0.00443 & \\
\hline Uranium-238 & Drive Point & B12XK9 & $\mathrm{N}$ & 9/17/01 & 46.8 & 0.56 & 0.0045 & \\
\hline Uranium-238 & Drive Point & B190X1 & $\mathrm{N}$ & $4 / 12 / 04$ & 47.8 & 0.51 & 0.0136 & \\
\hline Uranium-238 & Drive Point & B190W5 & $\mathrm{N}$ & $4 / 12 / 04$ & 49.9 & 0.65 & 0.0155 & \\
\hline Uranium-238 & Drive Point & B12XL1 & $\mathrm{N}$ & 9/17/01 & 51.8 & 0.59 & 0.00459 & \\
\hline Uranium-238 & Drive Point & B12XL0 & $\mathrm{N}$ & 9/17/01 & 51.8 & 0.57 & 0.00901 & \\
\hline Uranium-238 & Drive Point & B190X9 & $\mathrm{N}$ & $4 / 12 / 04$ & 54.4 & 0.59 & 0.00904 & \\
\hline Uranium-238 & Drive Point & B190X5 & $\mathrm{N}$ & $4 / 12 / 04$ & 58.2 & 0.77 & 0.0197 & \\
\hline Uranium-238 & Drive Point & B12XK3 & $\mathrm{N}$ & 9/18/01 & 64.7 & 0.63 & 0.0121 & \\
\hline Uranium-238 & Drive Point & B12XL2 & $\mathrm{N}$ & $9 / 17 / 01$ & 67.9 & 0.64 & 0.0142 & \\
\hline
\end{tabular}

\section{A.3 Sediment Data}

The sediment data were provided by staff from the SESP. Sediment samples are taken as part of the annual Hanford Site monitoring in locations near seeps and other locations along the Columbia River shoreline of the 300 Area.

\section{A.3.1 Uranium-234 Sediment Data}

There were 18 sediment samples of uranium-234 at the 300 Area location. The samples were collected between 11/1/1999 and 10/25/2004. The values are plotted in Figure A.9, and the data are presented in Table A.9.

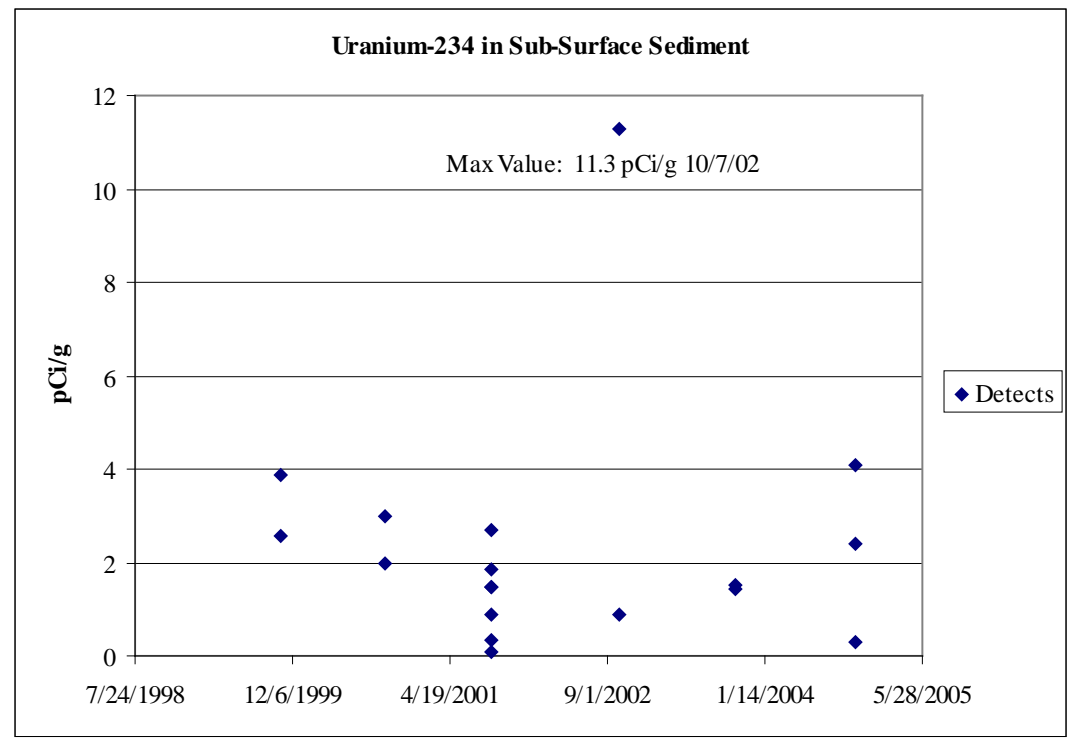

Figure A.9. Uranium-234 in Sub-Surface Sediment Associated with the 300 Area 
Table A.9. Uranium-234 Data in Sub-Surface Sediment in the 300 Area

\begin{tabular}{|c|c|c|c|c|c|c|c|c|}
\hline Analyte & Sample Site & $\begin{array}{c}\text { Sample } \\
\text { Number }\end{array}$ & $\begin{array}{l}\text { Sample } \\
\text { Date }\end{array}$ & $\begin{array}{c}\text { Value } \\
\text { (pCi/g) }\end{array}$ & $\begin{array}{c}\text { Counting } \\
\text { Error }\end{array}$ & MDA & \% Moisture & $\begin{array}{c}\text { Quali- } \\
\text { fier }\end{array}$ \\
\hline Uranium-234 & 300 Area Spr DR 42-2 & B0WDR2 & $11 / 1 / 99$ & 3.89 & 0.12 & 0.0102 & 79.5 & \\
\hline Uranium-234 & 300 Area Spring 42-2 & B0WDL8 & $11 / 1 / 99$ & 2.56 & 0.099 & 0.01 & 74.4 & \\
\hline Uranium-234 & 300 Area Spr DR 42-2 & B10922 & 9/27/00 & 3.01 & 0.094 & 0.00501 & 71.5 & \\
\hline Uranium-234 & 300 Area Spring 42-2 & B10908 & $9 / 27 / 00$ & 1.97 & 0.077 & 0.00205 & 75.2 & \\
\hline Uranium-234 & 300 Area Spr DR 42-2 & B12T05 & $8 / 27 / 01$ & 1.4704455 & & & & \\
\hline Uranium-234 & 300 Area Spring 42-2 & B12T04 & $8 / 27 / 01$ & 0.896004 & & & & \\
\hline Uranium-234 & 300 Spr 11 & B12T06 & $8 / 27 / 01$ & 1.4729431 & & & & \\
\hline Uranium-234 & 300 Spr 14 & B12T07 & $8 / 27 / 01$ & 0.0705564 & & & & \\
\hline Uranium-234 & 300 Area Spring 42-2 & B12RL9 & $8 / 27 / 01$ & 2.71 & 0.092 & 0.00537 & 75.1 & \\
\hline Uranium-234 & 300 Spr 11 & B12RY9 & $8 / 27 / 01$ & 1.85 & 0.076 & 0.00433 & 78.3 & \\
\hline Uranium-234 & 300 Spr 14 & B12T01 & $8 / 27 / 01$ & 0.328 & 0.033 & 0.00564 & 75.6 & \\
\hline Uranium-234 & 300 Area Spr DR 42-2 & B15C47 & $10 / 7 / 02$ & 11.3 & 0.18 & 0.0019 & 60.5 & \\
\hline Uranium-234 & 300 Area Spring 42-2 & B15C07 & $10 / 7 / 02$ & 0.872 & 0.051 & 0.00198 & 77 & \\
\hline Uranium-234 & 300 Area Spr DR 42-2 & B17J59 & $10 / 13 / 03$ & 1.52 & 0.075 & 0.0098 & 73.2 & \\
\hline Uranium-234 & 300 Area Spring 42-2 & B17J20 & $10 / 13 / 03$ & 1.42 & 0.068 & 0.00219 & 68.4 & \\
\hline Uranium-234 & 300 Area Spr DR 42-2 & B1BFR3 & $10 / 25 / 04$ & 4.07 & 0.1 & 0.00515 & & \\
\hline Uranium-234 & 300 Area Spring 41-9 & B1BH12 & $10 / 25 / 04$ & 0.279 & 0.028 & 0.00678 & & \\
\hline Uranium-234 & 300 Area Spring 42-2 & B1BFN9 & $10 / 25 / 04$ & 2.41 & 0.079 & 0.00988 & & \\
\hline
\end{tabular}

\section{A.3.2 Uranium-235 Sediment Data}

There were 28 (3 nondetect) sediment samples of uranium-235 at the 300 Area location. The samples were collected between 8/29/1994 and 10/6/2005. The values are plotted in Figure A.10, and the data are presented in Table A.10.

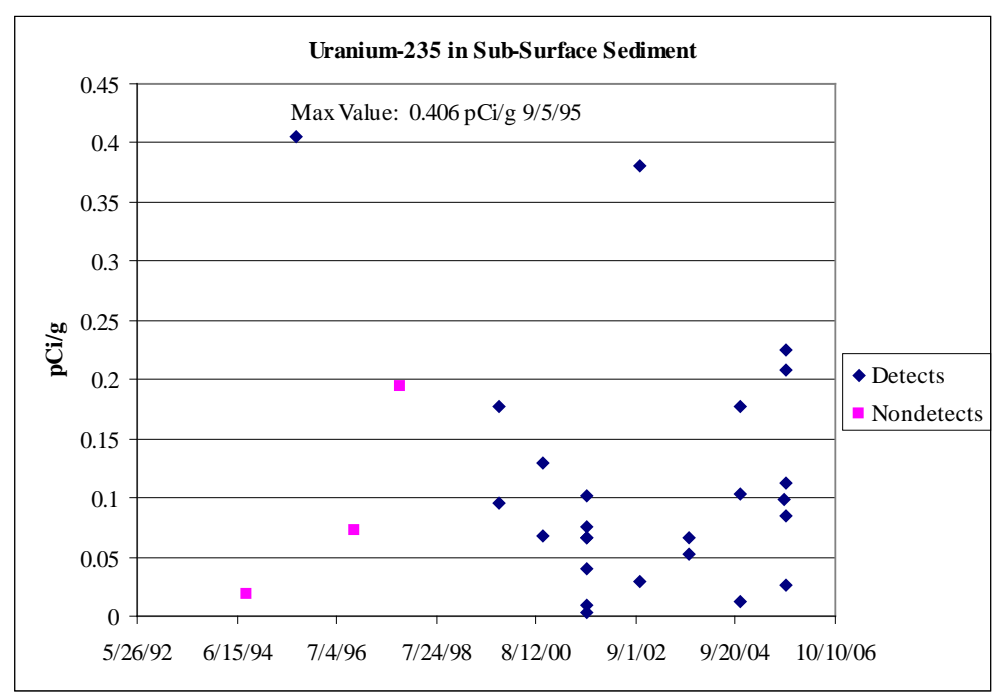

Figure A.10. Uranium-235 in Sub-Surface Sediment Associated with the 300 Area 
Table A.10. Uranium-235 Data in Sub-Surface Sediment in the 300 Area

\begin{tabular}{|c|c|c|c|c|c|c|c|c|}
\hline Analyte & Sample Site & $\begin{array}{c}\text { Sample } \\
\text { Number }\end{array}$ & $\begin{array}{c}\text { Sample } \\
\text { Date }\end{array}$ & $\begin{array}{l}\text { Value } \\
\mathrm{pCi} / \mathrm{g})\end{array}$ & $\begin{array}{c}\text { Counting } \\
\text { Error }\end{array}$ & MDA & \% Moisture & $\begin{array}{c}\text { Quali- } \\
\text { fier }\end{array}$ \\
\hline Uranium-235 & 300 Area Spring 42-2 & B0CDM6 & $8 / 29 / 94$ & 0.0188 & 0.158 & & & $\mathrm{U}$ \\
\hline Uranium-235 & 300 Area Spring 42-2 & B0J5H2 & $11 / 21 / 96$ & 0.0727 & 0.0705 & & & $\mathrm{U}$ \\
\hline Uranium-235 & 300 Area Spring 42-2 & B0M7V3 & $10 / 27 / 97$ & 0.194 & 0.112 & & & $\mathrm{U}$ \\
\hline Uranium-235 & 300 Area Spring 42-2 & B0G8W5 & 9/5/95 & 0.406 & 0.16 & & & \\
\hline Uranium-235 & 300 Area Spr DR 42-2 & B0WDR2 & $11 / 1 / 99$ & 0.177 & 0.025 & 0.0102 & 79.5 & \\
\hline Uranium-235 & 300 Area Spring 42-2 & B0WDL8 & $11 / 1 / 99$ & 0.0949 & 0.019 & 0.00655 & 74.4 & \\
\hline Uranium-235 & 300 Area Spr DR 42-2 & B10922 & $9 / 27 / 00$ & 0.129 & 0.019 & 0.00198 & 71.5 & \\
\hline Uranium-235 & 300 Area Spring 42-2 & B10908 & $9 / 27 / 00$ & 0.0677 & 0.014 & 0.00427 & 75.2 & \\
\hline Uranium-235 & 300 Spr 11 & B12RY9 & $8 / 27 / 01$ & 0.0757 & 0.015 & 0.00208 & 78.3 & \\
\hline Uranium-235 & 300 Spr 14 & B12T07 & $8 / 27 / 01$ & 0.0028695 & & & & \\
\hline Uranium-235 & 300 Area Spr DR 42-2 & B12T05 & $8 / 27 / 01$ & 0.0665435 & & & & \\
\hline Uranium-235 & 300 Spr 11 & B12T06 & $8 / 27 / 01$ & 0.0657629 & & & & \\
\hline Uranium-235 & 300 Spr 14 & B12T01 & $8 / 27 / 01$ & 0.00987 & 0.0061 & 0.00222 & 75.6 & \\
\hline Uranium-235 & 300 Area Spring 42-2 & B12T04 & $8 / 27 / 01$ & 0.0403677 & & & & \\
\hline Uranium-235 & 300 Area Spring 42-2 & B12RL9 & $8 / 27 / 01$ & 0.102 & 0.018 & 0.00212 & 75.1 & \\
\hline Uranium-235 & 300 Area Spring 42-2 & B15C07 & $10 / 7 / 02$ & 0.0297 & 0.0096 & 0.00198 & 77 & \\
\hline Uranium-235 & 300 Area Spr DR 42-2 & B15C47 & $10 / 7 / 02$ & 0.381 & 0.033 & 0.0019 & 60.5 & \\
\hline Uranium-235 & 300 Area Spr DR 42-2 & B17J59 & $10 / 13 / 03$ & 0.0667 & 0.017 & 0.0128 & 73.2 & \\
\hline Uranium-235 & 300 Area Spring 42-2 & B17J20 & $10 / 13 / 03$ & 0.052 & 0.013 & 0.00693 & 68.4 & \\
\hline Uranium-235 & 300 Area Spring 41-9 & B1BH12 & $10 / 25 / 04$ & 0.0119 & 0.0062 & 0.0047 & & \\
\hline Uranium-235 & 300 Area Spr DR 42-2 & B1BFR3 & $10 / 25 / 04$ & 0.177 & 0.022 & 0.00373 & & \\
\hline Uranium-235 & 300 Area Spring 42-2 & B1BFN9 & $10 / 25 / 04$ & 0.103 & 0.016 & 0.00547 & & \\
\hline Uranium-235 & 300 Area SHORELINE & & $9 / 26 / 05$ & 0.0991 & 0.018 & 0.0062 & 27.1 & \\
\hline Uranium-235 & 300 Area SHORELINE & & 9/28/05 & 0.225 & 0.026 & 0.00202 & 17.6 & \\
\hline Uranium-235 & 300 Area Spr DR 42-2 & & $10 / 6 / 05$ & 0.208 & 0.025 & 0.00198 & 27.5 & \\
\hline Uranium-235 & 300 Area Spring 42-2 & & $10 / 6 / 05$ & 0.0853 & 0.018 & 0.00249 & 29.9 & \\
\hline Uranium-235 & 300 Area Spring 42-7 & & $10 / 6 / 05$ & 0.113 & 0.019 & 0.00218 & 28.5 & \\
\hline Uranium-235 & 300 Area Spring 41-9 & & $10 / 6 / 05$ & 0.0269 & 0.011 & 0.00318 & 33.1 & \\
\hline
\end{tabular}

\section{A.3.3 Uranium-238 Sediment Data}

There were 28 sediment samples of uranium-238 at the 300 Area location. The samples were collected between 8/29/1994 and 10/6/2005. The values are plotted in Figure A.11, and the data are presented in Table A.11. 


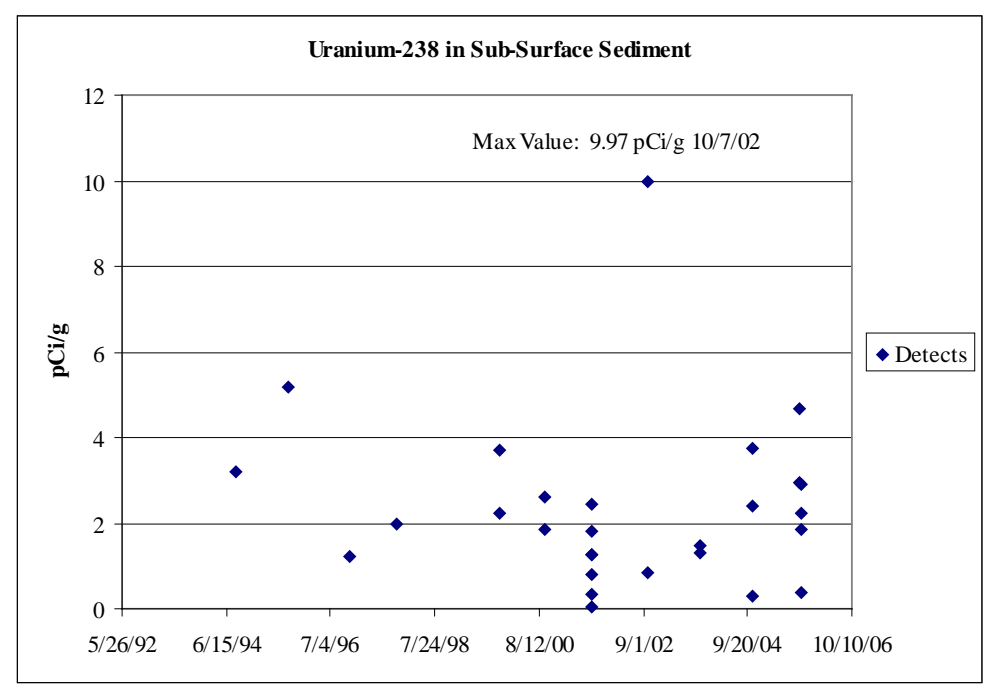

Figure A.11. Uranium-238 in Sub-Surface Sediment Associated with the 300 Area

Table A.11. Uranium-238 Data in Sub-Surface Sediment in the 300 Area

\begin{tabular}{|c|c|c|c|c|c|c|c|c|}
\hline Analyte & Sample Site & $\begin{array}{l}\text { Sample } \\
\text { Number }\end{array}$ & $\begin{array}{c}\text { Sample } \\
\text { Date }\end{array}$ & $\begin{array}{l}\text { Value } \\
\text { (pCi/g) }\end{array}$ & $\begin{array}{c}\text { Counting } \\
\text { Error }\end{array}$ & MDA & \% Moisture & $\begin{array}{c}\text { Quali- } \\
\text { fier }\end{array}$ \\
\hline "Uranium-238 & 300 Area Spring 42-2 & B0CDM6 & $8 / 29 / 94$ & 3.2 & 0.563 & & & \\
\hline Uranium-238 & 300 Area Spring 42-2 & B0G8W5 & 9/5/95 & 5.19 & 0.963 & & & \\
\hline Uranium-238 & 300 Area Spring 42-2 & B0J5H2 & $11 / 21 / 96$ & 1.22 & 0.46 & & & \\
\hline Uranium-238 & 300 Area Spring 42-2 & B0M7V3 & $10 / 27 / 97$ & 1.98 & 0.541 & & & \\
\hline Uranium-238 & 300 Area Spring 42-2 & B0WDL8 & $11 / 1 / 99$ & 2.24 & 0.092 & 0.00946 & 74.4 & \\
\hline Uranium-238 & 300 Area Spr DR 42-2 & B0WDR2 & $11 / 1 / 99$ & 3.71 & 0.11 & 0.019 & 79.5 & \\
\hline Uranium-238 & 300 Area Spr DR 42-2 & B10922 & $9 / 27 / 00$ & 2.62 & 0.087 & 0.00198 & 71.5 & \\
\hline Uranium-238 & 300 Area Spring 42-2 & B10908 & $9 / 27 / 00$ & 1.86 & 0.075 & 0.0052 & 75.2 & \\
\hline Uranium-238 & 300 Area Spring 42-2 & B12T04 & $8 / 27 / 01$ & 0.785 & & & & \\
\hline Uranium-238 & 300 Spr 14 & B12T07 & $8 / 27 / 01$ & 0.0506 & & & & \\
\hline Uranium-238 & 300 Area Spr DR 42-2 & B12T05 & $8 / 27 / 01$ & 1.27 & & & & \\
\hline Uranium-238 & 300 Spr 11 & B12RY9 & $8 / 27 / 01$ & 1.79 & 0.074 & 0.00208 & 78.3 & \\
\hline Uranium-238 & 300 Spr 11 & B12T06 & $8 / 27 / 01$ & 1.27 & & & & \\
\hline Uranium-238 & 300 Spr 14 & B12T01 & $8 / 27 / 01$ & 0.346 & 0.034 & 0.00564 & 75.6 & \\
\hline Uranium-238 & 300 Area Spring 42-2 & B12RL9 & $8 / 27 / 01$ & 2.45 & 0.088 & 0.00442 & 75.1 & \\
\hline Uranium-238 & 300 Area Spr DR 42-2 & B15C47 & $10 / 7 / 02$ & 9.97 & 0.17 & 0.00515 & 60.5 & \\
\hline Uranium-238 & 300 Area Spring 42-2 & B15C07 & $10 / 7 / 02$ & 0.832 & 0.049 & 0.00198 & 77 & \\
\hline Uranium-238 & 300 Area Spring 42-2 & B17J20 & $10 / 13 / 03$ & 1.3 & 0.065 & 0.00749 & 68.4 & \\
\hline Uranium-238 & 300 Area Spr DR 42-2 & B17J59 & $10 / 13 / 03$ & 1.46 & 0.073 & 0.00845 & 73.2 & \\
\hline Uranium-238 & 300 Area Spring 41-9 & B1BH12 & $10 / 25 / 04$ & 0.291 & 0.029 & 0.00789 & & \\
\hline Uranium-238 & 300 Area Spr DR 42-2 & B1BFR3 & $10 / 25 / 04$ & 3.75 & 0.1 & 0.00566 & & \\
\hline Uranium-238 & 300 Area Spring 42-2 & B1BFN9 & $10 / 25 / 04$ & 2.41 & 0.079 & 0.00668 & & \\
\hline Uranium-238 & 300 Area SHORELINE & & $9 / 26 / 05$ & 2.96 & 0.097 & 0.00545 & 27.1 & \\
\hline Uranium-238 & 300 Area SHORELINE & & $9 / 28 / 05$ & 4.66 & 0.12 & 0.00421 & 17.6 & \\
\hline Uranium-238 & 300 Area Spring 41-9 & & $10 / 6 / 05$ & 0.373 & 0.043 & 0.0165 & 33.1 & \\
\hline Uranium-238 & 300 Area Spring 42-2 & & $10 / 6 / 05$ & 1.85 & 0.083 & 0.00678 & 29.9 & \\
\hline Uranium-238 & 300 Area Spr DR 42-2 & & $10 / 6 / 05$ & 2.91 & 0.092 & 0.00787 & 27.5 & \\
\hline Uranium-238 & 300 Area Spring 42-7 & & $10 / 6 / 05$ & 2.25 & 0.085 & 0.00746 & 28.5 & \\
\hline
\end{tabular}




\section{A.4 Guide to Data Qualifiers}

Many of the tables in the preceding sections contain codes that are qualifiers on the data values. The codes and their meanings are presented in Table A.12.

Table A.12. Qualifiers Definitions for the 300-FF-5 Data

\begin{tabular}{|c|c|c|}
\hline Media & Qualifier & Meaning \\
\hline Seep Water & $\overline{\mathrm{D}}$ & $\begin{array}{l}\text { Analyte was identified in an analysis at a secondary dilution factor } \\
\text { (i.e., dilution factor different than 1.0) }\end{array}$ \\
\hline $\begin{array}{l}\text { Seep Water, Surface } \\
\text { Water }\end{array}$ & $\mathrm{J}$ & $\begin{array}{l}\text { Value reported is estimated because it was detected at a level } \\
\text { less than the Required Detection Limit (RDL) or Practical Quantitation Limit (PQL) and } \\
\text { greater than or equal to the MDL. }\end{array}$ \\
\hline Surface Water & $\mathrm{L}$ & $\begin{array}{l}\text { Value is between the Method Detection Limit (MDL) and the Contract-Required } \\
\text { Quantitation Limit (CRQL) }\end{array}$ \\
\hline $\begin{array}{l}\text { Seep Water, Surface } \\
\text { Water }\end{array}$ & $\mathrm{N}$ & Matrix spike duplicate is outside of the control limits \\
\hline $\begin{array}{l}\text { Pore Water, } \\
\text { Sediment, Seep } \\
\text { Water, Soil, Surface } \\
\text { Water }\end{array}$ & $\mathrm{U}$ & $\begin{array}{l}\text { Indicates constituent was analyzed for but not detected or value reported }<0 \text {; value reported } \\
<\text { counting error; value reported }<\text { total analytical error; value reported }<=\text { contract MDL, } \\
\text { IDL, Minimum Detectable Activity (MDA), or PQL. For metals, "U” qualifier may be } \\
\text { represented by the contract MDL. }\end{array}$ \\
\hline $\begin{array}{l}\text { Seep Water, Surface } \\
\text { Water }\end{array}$ & UN & Characteristics from both “U” and "N" qualifiers exist \\
\hline $\begin{array}{l}\text { Pore Water, Surface } \\
\text { Water }\end{array}$ & $\mathrm{X}$ & $\begin{array}{l}\text { The value-specific reason for this qualifier is provided in the hard copy data report and/or } \\
\text { case narrative. Additional values-specific information may also be found in the RESULT } \\
\text { COMMENT field for this record. }\end{array}$ \\
\hline
\end{tabular}

\section{A.5 Corbicula Data}

There were 70 samples of uranium in Corbicula at the 300 Area. The samples were collected between 10/30/2002 and 2/2/2005. The values are plotted in Figure A.12, and the data are presented in Table A.13.

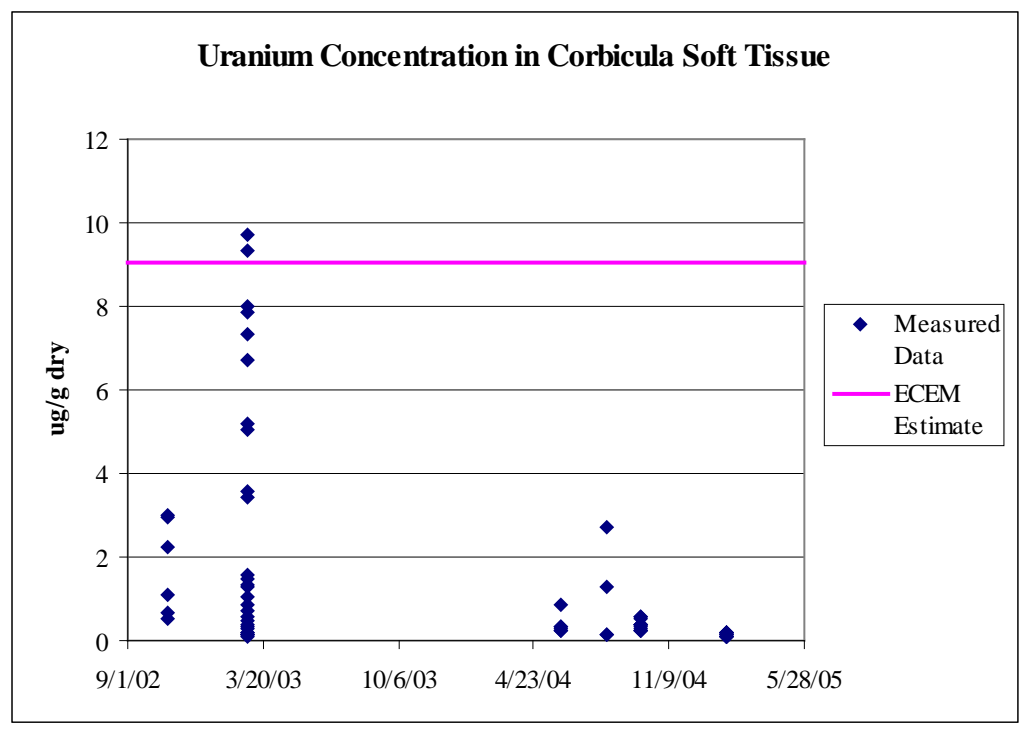

Figure A.12. Uranium in Corbicula 
Table A.13. Uranium Data in Corbicula Soft Tissue in the 300 Area

\begin{tabular}{|c|c|c|c|c|c|c|}
\hline Species & Sampled Item & Contaminant & Sample Date & Value & Units & SAMP_SITE_NAME \\
\hline Corbicula & Soft tissue & Uranium & 30-Oct-02 & 2.25 & $\mu \mathrm{g} / \mathrm{g}$ & 300 AREA spring 42-2 \\
\hline Corbicula & Soft tissue & Uranium & 30-Oct-02 & 2.94 & $\mu g / g$ & 300 AREA SPR DR 42-2 \\
\hline Corbicula & Soft tissue & Uranium & $30-$ Oct-02 & 2.99 & $\mu \mathrm{g} / \mathrm{g}$ & 300 AREA SPRING 42-2 \\
\hline Corbicula & Soft tissue & Uranium & 30-Oct-02 & 1.1 & $\mu \mathrm{g} / \mathrm{g}$ & 300 AREA SPRING 42-2 \\
\hline Corbicula & Soft tissue & Uranium & 30-Oct-02 & 0.678 & $\mu g / g$ & 300 AREA SPR DR 42-2 \\
\hline Corbicula & Soft tissue & Uranium & 30-Oct-02 & 0.524 & $\mu \mathrm{g} / \mathrm{g}$ & 300 AREA SPR DR 42-2 \\
\hline Corbicula & Soft tissue & Uranium & 24-Feb-03 & 0.109 & $\mu \mathrm{g} / \mathrm{g}$ & 300 SPR 14 \\
\hline Corbicula & Soft tissue & Uranium & 24-Feb-03 & 1.29 & $\mu \mathrm{g} / \mathrm{g}$ & 300 SPR 11 \\
\hline Corbicula & Soft tissue & Uranium & 24-Feb-03 & 1.07 & $\mu g / g$ & 300 SPR 11 \\
\hline Corbicula & Soft tissue & Uranium & 24-Feb-03 & 1.59 & $\mu \mathrm{g} / \mathrm{g}$ & 300 SPR 11 \\
\hline Corbicula & Soft tissue & Uranium & 24-Feb-03 & 1.35 & $\mu \mathrm{g} / \mathrm{g}$ & 300 SPR 11 \\
\hline Corbicula & Soft tissue & Uranium & 24-Feb-03 & 1.49 & $\mu \mathrm{g} / \mathrm{g}$ & 300 SPR 11 \\
\hline Corbicula & Soft tissue & Uranium & 24-Feb-03 & 0.126 & $\mu \mathrm{g} / \mathrm{g}$ & 300 SPR 14 \\
\hline Corbicula & Soft tissue & Uranium & 24-Feb-03 & 0.575 & $\mu \mathrm{g} / \mathrm{g}$ & 300 SPR 11 \\
\hline Corbicula & Soft tissue & Uranium & 24-Feb-03 & 0.264 & $\mu \mathrm{g} / \mathrm{g}$ & 300 SPR 14 \\
\hline Corbicula & Soft tissue & Uranium & 24-Feb-03 & 0.346 & $\mu g / g$ & 300 SPR 11 \\
\hline Corbicula & Soft tissue & Uranium & 24-Feb-03 & 0.138 & $\mu \mathrm{g} / \mathrm{g}$ & 300 SPR 14 \\
\hline Corbicula & Soft tissue & Uranium & 24-Feb-03 & 0.37 & $\mu \mathrm{g} / \mathrm{g}$ & 300 SPR 14 \\
\hline Corbicula & Soft tissue & Uranium & 24-Feb-03 & 0.196 & $\mu g / g$ & 300 SPR 14 \\
\hline Corbicula & Soft tissue & Uranium & 24-Feb-03 & 5.2 & $\mu \mathrm{g} / \mathrm{g}$ & 300 AREA SPRING 42-2 \\
\hline Corbicula & Soft tissue & Uranium & 24-Feb-03 & 7.32 & $\mu \mathrm{g} / \mathrm{g}$ & 300 AREA SPR DR 42-2 \\
\hline Corbicula & Soft tissue & Uranium & 24-Feb-03 & 9.71 & $\mu \mathrm{g} / \mathrm{g}$ & 300 AREA SPR DR 42-2 \\
\hline Corbicula & Soft tissue & Uranium & 24-Feb-03 & 9.32 & $\mu \mathrm{g} / \mathrm{g}$ & 300 AREA SPR DR 42-2 \\
\hline Corbicula & Soft tissue & Uranium & 24-Feb-03 & 3.44 & $\mu \mathrm{g} / \mathrm{g}$ & 300 SPR 11 \\
\hline Corbicula & Soft tissue & Uranium & 24-Feb-03 & 0.705 & $\mu \mathrm{g} / \mathrm{g}$ & 300 AREA SPRING 42-2 \\
\hline Corbicula & Soft tissue & Uranium & 24-Feb-03 & 6.7 & $\mu \mathrm{g} / \mathrm{g}$ & 300 AREA SPR DR 42-2 \\
\hline Corbicula & Soft tissue & Uranium & 24-Feb-03 & 3.59 & $\mu \mathrm{g} / \mathrm{g}$ & 300 AREA SPRING 42-2 \\
\hline Corbicula & Soft tissue & Uranium & 24-Feb-03 & 8.01 & $\mu \mathrm{g} / \mathrm{g}$ & 300 AREA SPR DR 42-2 \\
\hline Corbicula & Soft tissue & Uranium & 24-Feb-03 & 5.04 & $\mu \mathrm{g} / \mathrm{g}$ & 300 AREA SPR DR 42-2 \\
\hline Corbicula & Soft tissue & Uranium & 24-Feb-03 & 7.86 & $\mu \mathrm{g} / \mathrm{g}$ & 300 AREA SPR DR 42-2 \\
\hline Corbicula & Soft tissue & Uranium & 24-Feb-03 & 0.478 & $\mu \mathrm{g} / \mathrm{g}$ & 300 AREA SPR DR 42-2 \\
\hline Corbicula & Soft tissue & Uranium & 24-Feb-03 & 0.869 & $\mu \mathrm{g} / \mathrm{g}$ & 300 AREA SPR DR 42-2 \\
\hline Corbicula & Soft tissue & Uranium & 24-Feb-03 & 0.184 & $\mu \mathrm{g} / \mathrm{g}$ & 300 AREA SPR DR 42-2 \\
\hline Corbicula & Soft tissue & Uranium & 24-Feb-03 & 0.127 & $\mu \mathrm{g} / \mathrm{g}$ & 300 SPR 14 \\
\hline Corbicula & Soft tissue & Uranium & 03-Jun-04 & 0.304 & $\mu \mathrm{g} / \mathrm{g}$ & 300 AREA SPR DR 42-2 \\
\hline Corbicula & Soft tissue & Uranium & 03-Jun-04 & 0.251 & $\mu \mathrm{g} / \mathrm{g}$ & 300 AREA SPR DR 42-2 \\
\hline Corbicula & Soft tissue & Uranium & 03-Jun-04 & 0.842 & $\mu \mathrm{g} / \mathrm{g}$ & 300 AREA SPR DR 42-2 \\
\hline Corbicula & Soft tissue & Uranium & 03-Jun-04 & 0.236 & $\mu \mathrm{g} / \mathrm{g}$ & 300 AREA SPR DR 42-2 \\
\hline Corbicula & Soft tissue & Uranium & 03-Jun-04 & 0.326 & $\mu \mathrm{g} / \mathrm{g}$ & 300 AREA SPR DR 42-2 \\
\hline Corbicula & Soft tissue & Uranium & 03-Jun-04 & 0.325 & $\mu \mathrm{g} / \mathrm{g}$ & 300 AREA SPR DR 42-2 \\
\hline Corbicula & Soft tissue & Uranium & 09-Aug-04 & 1.27 & $\mu \mathrm{g} / \mathrm{g}$ & 300 AREA SPRING 42-2 \\
\hline Corbicula & Soft tissue & Uranium & 09-Aug-04 & 2.7 & $\mu \mathrm{g} / \mathrm{g}$ & 300 AREA SPR DR 42-2 \\
\hline Corbicula & Soft tissue & Uranium & 09-Aug-04 & 0.121 & $\mu \mathrm{g} / \mathrm{g}$ & 300 AREA SPR DR 42-2 \\
\hline Corbicula & Soft tissue & Uranium & 09-Aug-04 & 0.15 & $\mu \mathrm{g} / \mathrm{g}$ & 300 AREA SPRING 42-2 \\
\hline Corbicula & Soft tissue & Uranium & 27-Sep-04 & 0.538 & $\mu \mathrm{g} / \mathrm{g}$ & 300 AREA SPR DR 42-2 \\
\hline Corbicula & Soft tissue & Uranium & 27-Sep-04 & 0.261 & $\mu \mathrm{g} / \mathrm{g}$ & 300 AREA SPR DR 42-2 \\
\hline
\end{tabular}


Table A.13. (contd)

\begin{tabular}{|c|c|c|c|c|c|c|}
\hline Species & Sampled Item & Contaminant & Sample Date & Value & Units & SAMP_SITE_NAME \\
\hline Corbicula & Soft tissue & Uranium & 27-Sep-04 & 0.237 & $\overline{\mu \mu g / g}$ & "300 AREA SPR DR 42-2 \\
\hline Corbicula & Soft tissue & Uranium & 27-Sep-04 & 0.381 & $\mu g / g$ & 300 AREA SPR DR 42-2 \\
\hline Corbicula & Soft tissue & Uranium & 27-Sep-04 & 0.389 & $\mu \mathrm{g} / \mathrm{g}$ & 300 AREA SPR DR 42-2 \\
\hline Corbicula & Soft tissue & Uranium & 27-Sep-04 & 0.383 & $\mu \mathrm{g} / \mathrm{g}$ & 300 AREA SPR DR 42-2 \\
\hline Corbicula & Soft tissue & Uranium & 27-Sep-04 & 0.34 & $\mu g / g$ & 300 AREA SPR DR 42-2 \\
\hline Corbicula & Soft tissue & Uranium & 27-Sep-04 & 0.28 & $\mu \mathrm{g} / \mathrm{g}$ & 300 AREA SPR DR 42-2 \\
\hline Corbicula & Soft tissue & Uranium & 27-Sep-04 & 0.23 & $\mu g / g$ & 300 AREA SPR DR 42-2 \\
\hline Corbicula & Soft tissue & Uranium & 27-Sep-04 & 0.565 & $\mu \mathrm{g} / \mathrm{g}$ & 300 AREA SPR DR 42-2 \\
\hline Corbicula & Soft tissue & Uranium & 27-Sep-04 & 0.55 & $\mu \mathrm{g} / \mathrm{g}$ & 300 AREA SPR DR 42-2 \\
\hline Corbicula & Soft tissue & Uranium & 27-Sep-04 & 0.391 & $\mu \mathrm{g} / \mathrm{g}$ & 300 AREA SPR DR 42-2 \\
\hline Corbicula & Soft tissue & Uranium & 02-Feb-05 & 0.115 & $\mu \mathrm{g} / \mathrm{g}$ & 300 AREA SPR DR 42-2 \\
\hline Corbicula & Soft tissue & Uranium & 02-Feb-05 & 0.182 & $\mu \mathrm{g} / \mathrm{g}$ & 300 AREA DR HRM 40 \\
\hline Corbicula & Soft tissue & Uranium & 02-Feb-05 & 0.133 & $\mu \mathrm{g} / \mathrm{g}$ & 300 AREA DR HRM 40 \\
\hline Corbicula & Soft tissue & Uranium & 02-Feb-05 & 0.141 & $\mu \mathrm{g} / \mathrm{g}$ & 300 AREA DR HRM 40 \\
\hline Corbicula & Soft tissue & Uranium & 02-Feb-05 & 0.116 & $\mu \mathrm{g} / \mathrm{g}$ & 300 AREA DR HRM 40 \\
\hline Corbicula & Soft tissue & Uranium & 02-Feb-05 & 0.175 & $\mu \mathrm{g} / \mathrm{g}$ & 300 AREA DR HRM 40 \\
\hline Corbicula & Soft tissue & Uranium & 02-Feb-05 & 0.19 & $\mu \mathrm{g} / \mathrm{g}$ & 300 AREA SPR DR 42-2 \\
\hline Corbicula & Soft tissue & Uranium & 02-Feb-05 & 0.0933 & $\mu g / g$ & 300 AREA SPR DR 42-2 \\
\hline Corbicula & Soft tissue & Uranium & 02-Feb-05 & 0.18 & $\mu g / g$ & 300 AREA SPR DR 42-2 \\
\hline Corbicula & Soft tissue & Uranium & 02-Feb-05 & 0.206 & $\mu \mathrm{g} / \mathrm{g}$ & 300 AREA SPR DR 42-2 \\
\hline Corbicula & Soft tissue & Uranium & 02-Feb-05 & 0.187 & $\mu \mathrm{g} / \mathrm{g}$ & 300 AREA SPR DR 42-2 \\
\hline Corbicula & Soft tissue & Uranium & 02-Feb-05 & 0.111 & $\mu \mathrm{g} / \mathrm{g}$ & 300 AREA SPR DR 42-2 \\
\hline Corbicula & Soft tissue & Uranium & 02-Feb-05 & 0.119 & $\mu \mathrm{g} / \mathrm{g}$ & 300 AREA DR HRM 40 \\
\hline Corbicula & Soft tissue & Uranium & 02-Feb-05 & 0.123 & $\mu \mathrm{g} / \mathrm{g}$ & 300 AREA SPR DR 42-2 \\
\hline
\end{tabular}



Appendix B

Discussion of the Mathematical Basis for the Ecological Chemical Exposure Model 



\section{Appendix B - Discussion of the Mathematical Basis for the Ecological Chemical Exposure Model}

The Ecological Chemical Exposure Model (ECEM) mathematically describes the biological, chemical and physical interactions of chemicals within an aquatic food chain. The equations described in the mathematical formulation section have been incorporated into a computer c called ECEM (Ecological Contaminant Exposure Model) described by Eslinger et al. (2002 and 2006). The current version of the computer model matches the updated mathematical formulation provided in this appendix. Several features of this model are different from screening-level ecological risk models, and most often ECEM would be applied only when screening-level models exceed action thresholds. First, this model is designed to support the needs of detailed site-specific analyses rather than generic analyses. Thus, for example, a site-specific food web would be developed rather than using a generic food web. Second, this computer model supports simultaneous calculations at more than one location and time. A useful output is animation of risk contours over time for a wide spatial domain. Because several levels of predators can be used in a food web, care must be used to select realistic inputs rather than so-called conservative inputs or the resulting body burdens may be overestimated so badly as to not be useful. Finally, this computer model was designed in a stochastic framework to allow examination of the effects of parameter uncertainty. The stochastic approach is well integrated with a deterministic approach, so it can be run for a single realization with constant inputs. In particular, the stochastic features of ECEM were used in the discussion of Section 6, where standard values, laboratory values and field measures are all compared.

An example application of the earlier version of ECEM has been published by Bryce et al. 2002. That analysis modeled 59 species along the riparian zone and in the Columbia River and examined chromium (metal), carbon tetrachloride (organic), and a suite of radioactive contaminants (including uranium as a radiological isotope and a chemical). The current version of ECEM was used in an assessment of Hanford's 300-FF-5 Groundwater Operable Unit (Miley et al. 2007). ECEM was also used to analyze the ecological effects of metals and a suite of organics released into a canal near a manufacturing complex in Italy. Another application to a contaminated site in Mexico modeled a suite of organic contaminants in a marine environment and produced both estimates of ecological risk and concentrations of contaminants in game fish for consumption by human fishermen.

This appendix discusses the basis for the model. The sections are divided into calculation of the body burden in the aquatic organisms and tissue benchmark concentration, and the radiological dose estimation.

\section{B.1 Body Burden Calculations}

For this report, the benthic ecological food web contains a subset of all the species found in ECEM. This section discusses the body burden calculations for aquatic animals, aquatic plants, and the consumption of aquatic species.

Parameters for the equations in ECEM may be specific to a contaminant, species, exposure condition, or a combination of all three, and may be generated by additional equations (described in Appendix B), or obtained from field or literature values as described in the next section. The indices on the variables in these equations reflect only dependence on species, indicated by i and j, and contaminant, indicated by c. 
The basic models used in the risk assessment model to estimate exposures of aquatic organisms to metal or organic contaminants in sediments, pore water, surface water, and the subsequent transfer through the food chain consist of mass-balance equilibrium models originally derived by Thomann 1989 and Thomann et al. 1992 and 1995. The basic equilibrium models presented in those papers were further modified by the authors to provide a system of equations generally applicable when only sediment data are available. The essential assumption used in that modification is that the aquatic system is not depurating contaminants, such that the three abiotic compartments (sediment, pore water, and surface water) are in static equilibrium (Thomann et al. 1992). This assumption may only be valid for large lacustrine systems; clearly, it is invalid for streams. However, the basic models may be used directly with only minor modification to address these more dynamic systems.

\section{B.1.1 Body burden for aquatic animals}

The body burden in a predator species $\mathrm{i}, \mathrm{V}_{\mathrm{i}}$, is calculated from direct exposure to contaminated water, ingestion of contaminated prey, and ingestion of contaminated sediment, using the following equation:

$$
\begin{aligned}
& \mathrm{V}(\mathrm{i}, \mathrm{c})=\left[\mathrm{BCF}(\mathrm{i}, \mathrm{c}) \times\left(\mathrm{b}_{\text {pore }}(\mathrm{i}) \times \mathrm{EC}_{\text {pore }}(\mathrm{c})+\left[1-\mathrm{b}_{\text {pore }}(\mathrm{i})\right] \times \mathrm{EC}_{\text {surf }}(\mathrm{c})\right)\right]+\left[\frac{\sum_{\mathrm{j} \neq \mathrm{i}}(\mathrm{P}(\mathrm{i}, \mathrm{j}) \times \alpha(\mathrm{i}, \mathrm{c}) \times \mathrm{I}(\mathrm{i}, \mathrm{j}) \times \mathrm{V}(\mathrm{j}, \mathrm{c}))}{\mathrm{K}(\mathrm{i}, \mathrm{c})+\mathrm{G}(\mathrm{i})}\right]+ \\
& {\left[\mathrm{EC}_{\text {sed }}(\mathrm{c}) \times \mathrm{SD}(\mathrm{i}) \times \alpha(\mathrm{i}, \mathrm{c}) \times\left(\frac{\sum_{\mathrm{j} \neq \mathrm{i}}(\mathrm{P}(\mathrm{i}, \mathrm{j}) \times \mathrm{I}(\mathrm{i}, \mathrm{j}))}{\mathrm{K}(\mathrm{i}, \mathrm{c})+\mathrm{G}(\mathrm{i})}\right)\right]}
\end{aligned}
$$

where V(i,c) is the body burden in predator species i (metals: pCi/kg dry weight (Thomann et al. 1995)), $\mathrm{BCF}(\mathrm{i}, \mathrm{c})$ is the bioconcentration factor for species $\mathrm{i}$ and contaminant c ( $\mathrm{L} / \mathrm{kg}$ dry weight for inorganics), $\mathrm{b}_{\text {pore }}(\mathrm{i})$ is the relative exposure to pore water (unitless), $\mathrm{EC}_{\text {pore }}(\mathrm{c})$ is the contaminant concentration in pore water $(\mathrm{pCi} / \mathrm{L}), \mathrm{EC}_{\text {surf }}(\mathrm{c})$ is the contaminant concentration in surface water $(\mathrm{pCi} / \mathrm{L}), \alpha(\mathrm{i}, \mathrm{c})$ is the chemical assimilation efficiency for contaminant consumed along with prey by species i (g contaminant assimilated/g contaminant ingested), $\mathrm{I}(\mathrm{i}, \mathrm{j})$ is the feeding rate of species $\mathrm{i}$ on prey item $\mathrm{j}$ (metal model: $\mathrm{g}$ prey dry weight/g predator dry weight/d), K(i,c) is the loss rate of contaminant for species i, including depuration and metabolism (1/d), G(i) is the growth rate of species i (1/d), $\mathrm{EC}_{\text {sed }}(\mathrm{c})$ is the contaminant concentration in sediment ( $\mathrm{pCi} / \mathrm{kg}$ ), and $\mathrm{SD}(\mathrm{i})$ is the feeding rate of species $\mathrm{i}$ on sediment as a fraction of total diet intake (kg sediment dry weight/kg prey dry weight/d).

The growth rate of species $\mathrm{i}$ is given by the regression equation from Thomann et al. 1992:

$$
\mathrm{G}(\mathrm{i})=\delta \times w \mathrm{w}(\mathrm{i})^{-\beta}
$$

where $\delta$ and $\beta$ are regression parameters and wm(i) is the body weight of species i (kg wet weight).

The oxygen respiration rate for species $\mathrm{i}$ is calculated from the equation:

$$
\rho(\mathrm{i})=\phi \times w m(i)^{-\gamma}
$$

where $\phi$ and $\gamma$ are regression parameters that can be found in Thomann 1989. 
BCF for metals is obtained from literature values or from laboratory experiments.

\section{B.1.2 Body burden for aquatic plants}

The body burden for aquatic plant species $\mathrm{i}, \mathrm{V}(\mathrm{i}, \mathrm{c})$, is calculated from the following equation from Thomann et al. 1995:

$$
\mathrm{V}(\mathrm{i}, \mathrm{c})=\mathrm{BCF}(\mathrm{i}, \mathrm{c}) \times\left(\mathrm{b}_{\text {pore }}(\mathrm{i}) \times \mathrm{EC}_{\text {pore }}(\mathrm{c})+\left[1-\mathrm{b}_{\text {pore }}(\mathrm{i})\right] \times \mathrm{EC}_{\text {surf }}(\mathrm{c})\right)
$$

\section{B.1.3 Body burden as consumed for aquatic species}

The equilibrium body burden for species i from ingestion of metals is calculated from the equation:

$$
\mathrm{C}(\mathrm{i}, \mathrm{c})=\mathrm{V}(\mathrm{i}, \mathrm{c}) / \mathrm{awd}(\mathrm{i})
$$

where $\mathrm{C}(\mathrm{i}, \mathrm{c})$ is the body burden for species i as consumed by predators ( $\mu \mathrm{g} / \mathrm{kg}$ or $\mathrm{pCi} / \mathrm{kg}$ wet).

\section{B.1.4 Tissue benchmark concentration}

The tissue benchmark calculation allows comparison of a body burden to a benchmark threshold. The ratio of tissue value to benchmark value for both plant and animal aquatic species for metal contaminants is calculated from the following equation:

$$
\mathrm{TB}(\mathrm{i}, \mathrm{c})=\mathrm{V}(\mathrm{i}, \mathrm{c}) \times 1000 \times \mathrm{f}_{\mathrm{L}}(\mathrm{i}) / \mathrm{BB}(\mathrm{i}, \mathrm{c})
$$

where $\mathrm{TB}(\mathrm{i}, \mathrm{c})$ is the the ratio of tissue value to benchmark value for species $\mathrm{i}$ (unitless), $\mathrm{BB}(\mathrm{i}, \mathrm{c})$ is the benchmark body burden value for species i ( $\mu \mathrm{g} / \mathrm{kg}$ lipid), and 1000 is a unit conversion factor ( $\mathrm{g} / \mathrm{kg}$ ).

\section{B.2 Radiological dose estimation}

The exposure equations return estimates of ingestion exposure to radiological contaminants in units of $\mathrm{pCi} / \mathrm{kg}$ body mass/d (that is, in units of radioactive decay rate density). However, radiological effects result from radioactive energy density absorbed by a body in a unit of time, which is usually expressed in units of $\mathrm{rad} / \mathrm{d}$. Consequently, decay rates must be converted to energy equivalents. Similarly, an organism can receive external energy from radioactive decay occurring in the abiotic media (air, water, or soil).

\section{B.2.1 Internal dose}

The internal total-body dose rate to an organism is the sum of the individual dose rates from each radionuclide in the body. The equation is written as follows:

$$
\mathrm{R}_{\text {int }}(\mathrm{i})=\sum_{\mathrm{c}}(\mathrm{C}(\mathrm{i}, \mathrm{c}) \times \mathrm{E}(\mathrm{i}, \mathrm{c}))
$$


where $R_{\text {int }}(i)$ is the radiological dose to organism i from internal radioactive decay (rad/d), C(i,c) is the specific body burden of nuclide $\mathrm{c}$ in organism $\mathrm{i}(\mathrm{pCi} / \mathrm{kg})$, and $\mathrm{E}(\mathrm{i}, \mathrm{c})$ is the effective absorbed energy rate for nuclide c per unit activity in organism i $(\mathrm{kg} \mathrm{rad} / \mathrm{pCi} / \mathrm{d})$.

Doses are summed across all radionuclides. As shown in Baker and Soldat 1992, the effective absorbed energy rate for nuclide c per unit activity in organism i can be calculated from the following equation:

$$
\begin{gathered}
\mathrm{E}(\mathrm{i}, \mathrm{c})=1 \mathrm{Ci} / 10^{12} \mathrm{pCi} \times 3.7 \times 10^{10} \text { disintegrations } / \mathrm{s} / \mathrm{Ci} \times 86,400 \mathrm{~s} / \mathrm{d} \times 1.602 \times 10^{-11} \mathrm{~kg} \mathrm{rad} / \mathrm{MeV} \times \varepsilon_{\mathrm{i}, \mathrm{c}} \\
\mathrm{E}(\mathrm{i}, \mathrm{c})=5.12 \times 10^{-8} \times \varepsilon(\mathrm{i}, \mathrm{c})
\end{gathered}
$$

where $\varepsilon(\mathrm{i}, \mathrm{c})$ is the is the effective absorbed energy (MeV/disintegration).

\section{B.2.2 External dose from water immersion for aquatic organisms}

The external radiological dose to aquatic organism i from exposure to radioactive decay in water is calculated using the equation:

$$
\mathrm{R}_{\mathrm{imm}}(\mathrm{i})=\sum_{\mathrm{c}}\left[\left(\mathrm{b}_{\text {pore }}(\mathrm{i}) \times \mathrm{EC}_{\text {pore }}(\mathrm{c})+\left(1-\mathrm{b}_{\text {pore }}(\mathrm{i})\right) \times \mathrm{EC}_{\text {surf }}(\mathrm{c})\right) \times \mathrm{DF}_{\text {imm }}(\mathrm{c}) \times \mathrm{CF}_{\text {imm }}\right]
$$

where the sum extends over all radiological contaminants (with index c): $\mathrm{R}_{\mathrm{imm}}(\mathrm{i})$ is the external radiological dose to organism i from exposure to radioactive decay in water $(\mathrm{rad} / \mathrm{d}), \mathrm{DF}_{\mathrm{imm}}$ (c) is the water immersion dose factor for nuclide c $\left(\mathrm{mrad} / \mathrm{yr}\right.$ per $\left.\mathrm{pCi} / \mathrm{m}^{3}\right)$, and $\mathrm{CF}_{\mathrm{imm}}$ is a unit conversion factor $\left(2.737851 \times 10^{-9}\right.$ to convert from $\left(\mathrm{mrad}^{3} \mathrm{~m}^{3}\right) /(\mathrm{L}-\mathrm{yr})$ to $\left.\mathrm{rad} / \mathrm{d}\right)$.

\section{B.2.3 External dose from contact with sediment for aquatic organisms}

External dose received from contact with sediment is calculated for aquatic species as the combination of external dose received above the sediment and below the sediment. The equations are the following Eckerman and Ryman (1993):

$$
\begin{gathered}
\text { RAbove }_{\text {sed }}(\mathrm{i})=\mathrm{F}_{\text {above }}(\mathrm{i}) \times \mathrm{CF}_{\text {sedelev }}(\mathrm{i}) \times \mathrm{DSF} \times \mathrm{SWD} \times \mathrm{CF}_{\text {above }} \times \sum_{\mathrm{c}}\left[\mathrm{EC}_{\text {sed }}(\mathrm{c}) \times \mathrm{DF}_{\text {sed }}(\mathrm{c})\right] \\
\operatorname{RBelow}_{\text {sed }}(\mathrm{i})=\left(1-\mathrm{F}_{\text {above }}(\mathrm{i})\right) \times \mathrm{MCF} \times \mathrm{CF}_{\text {below }} \times \sum_{\mathrm{c}}\left[\mathrm{EC}_{\text {sed }}(\mathrm{c}) \times \gamma(\mathrm{c})\right] \\
\mathrm{R}_{\text {sed }}(\mathrm{i})=\mathrm{RAbove}_{\text {sed }}(\mathrm{i})+\mathrm{RBelow}_{\text {sed }}(\mathrm{i})
\end{gathered}
$$

where the sum extends over all radiological contaminants (with index c), RAbove sed $_{(i)}$ is the external dose from exposure above the sediment ( $\mathrm{rad} / \mathrm{d}), \mathrm{F}_{\text {above }}(\mathrm{i})$ is the fractional time of organism $\mathrm{i}$ above the sediment (unitless), $\mathrm{CF}_{\text {sedelev }}(\mathrm{i})$ is 2 if $\mathrm{b}_{\text {pore }}(\mathrm{i})<0.5$ or 1 if $\mathrm{b}_{\text {pore }}(\mathrm{i})>=0.5$, DSF is a directional source factor for 1-sided exposure (unitless), SWD is a sediment conversion factor for wet weight to dry weight (unitless), $\mathrm{CF}_{\text {above }}$ is the conversion factor applicable above the sediment $=0.7 \times 5.12 \times 10^{8}$ to yield rad-kg doses, $\mathrm{DF}_{\text {sed }}(\mathrm{c})$ is the sediment dose factor for nuclide c (mrad-m²/pCi/yr), RBelow $\mathrm{sed}_{\text {sed }}(\mathrm{i})$ is the external dose from 
exposure below the sediment ( $\mathrm{rad} / \mathrm{d})$, MCF is a medium correction factor for sediment exposure (unitless), $\mathrm{CF}_{\text {below }}$ is the conversion factor applicable below the sediment $=1.05 \times 5.12 \times 1.0^{-8}$ to yield rad-kg doses, $\mathrm{EC}_{\text {sed }}$ (c) is the contaminant concentration in sediment for nuclide c (pCi/kg), $\gamma(\mathrm{c})$ is the gamma energy for nuclide $\mathrm{c}\left(\mathrm{MeV} /\right.$ disintegration), and $\mathrm{R}_{\text {sed }}(\mathrm{i})$ is the external radiological dose to organism i from exposure to radioactive decay in sediment ( $\mathrm{rad} / \mathrm{d})$.

\section{B.2.4 Total dose from radionuclide exposure}

Finally, total radiological dose ( $\mathrm{rad} / \mathrm{d})$ for aquatic organisms is obtained by summing the above quantities:

$$
\mathrm{R}_{\text {total }}(\mathrm{i})=\mathrm{R}_{\text {imm }}(\mathrm{i})+\mathrm{R}_{\text {sed }}(\mathrm{i})+\mathrm{R}_{\text {int }}(\mathrm{i})
$$

The total radiological dose (rad/d) for terrestrial organisms is obtained by summing the above quantities:

$$
\mathrm{R}_{\text {total }}(\mathrm{i})=\mathrm{R}_{\text {imm }}(\mathrm{i})+\mathrm{R}_{\text {soil }}(\mathrm{i})+\mathrm{R}_{\text {int }}(\mathrm{i})
$$

\section{B.3 References}

Bryce, RW, CT Kincaid, PW Eslinger, and LF Morasch LF, eds. 2002. An Initial Assessment of Hanford Impact Performed with the System Assessment Capability. PNNL-14027. Pacific Northwest National Laboratory, Richland, WA.

Eckerman, KF, and JC Ryman. 1993. External Exposure to Radionuclides in Air, Water, and Soil. EPA 402-R-93-081. U.S. Environmental Protection Agency, Office of Radiation and Indoor Air, Washington, D.C.

Eslinger, PW, C Arimescu, BA Kanyid, and TB Miley. 2002. User Instructions for the Systems Assessment Capability, Rev. 1, Computer Codes. Volume 2 Revised: Impact Modules. PNNL-13932Volume 2 Revised. Pacific Northwest National Laboratory, Richland, WA.

Eslinger, PW, TB Miley, C Arimescu, and BA Kanyid. 2006. User Instructions for the Systems Assessment Capability, Rev. 1, Computer Codes. Volume 2: Impact Modules. PNNL-14852, Volume 2, Pacific Northwest National Laboratory, Richland, WA.

Thomann, RV. 1989. Bioaccumulation model of organic chemical distribution in aquatic food chains. Environmental Science and Technology, 23:699-707.

Thomann, RV, JP Connolly, and TF Parkerton. 1992. An equilibrium model of organic chemical accumulation in aquatic food webs with sediment interaction. Environmental Toxicology and Chemistry 11:615-629.

Thomann, RV, JD Mahony, and R Mueller. 1995. Steady-state model of biota sediment accumulation factor for metals in two marine bivalves. Environmental Toxicology and Chemistry, 14(11):1989-1998. 